Cochrane Database of Systematic Reviews

\title{
Corticosteroid therapy for nephrotic syndrome in children (Review)
}

Hahn D, Hodson EM, Willis NS, Craig JC

Hahn D, Hodson EM, Willis NS, Craig JC.

Corticosteroid therapy for nephrotic syndrome in children.

Cochrane Database of Systematic Reviews 2015, Issue 3. Art. No.: CD001533.

DOI: 10.1002/14651858.CD001533.pub5.

www.cochranelibrary.com 
TABLE OF CONTENTS

HEADER

ABSTRACT

PLAIN LANGUAGE SUMMARY

SUMMARY OF FINDINGS

BACKGROUND

OBJECTIVES

METHODS

RESULTS

Figure 1.

Figure 2.

Figure 3.

DISCUSSION

AUTHORS' CONCLUSIONS

ACKNOWLEDGEMENTS

REFERENCES

CHARACTERISTICS OF STUDIES

DATA AND ANALYSES

Analysis 1.1. Comparison 1 Steroid therapy in first episode of nephrotic syndrome: 3 months versus 2 months of therapy, Outcome 1 Number with frequent relapses by 12 to 24 months.

Analysis 1.2. Comparison 1 Steroid therapy in first episode of nephrotic syndrome: 3 months versus 2 months of therapy, Outcome 2 Number of children relapsing by 12 to 24 months.

Analysis 1.3. Comparison 1 Steroid therapy in first episode of nephrotic syndrome: 3 months versus 2 months of therapy, Outcome 3 Mean relapse rate/patient/y.

Analysis 1.4. Comparison 1 Steroid therapy in first episode of nephrotic syndrome: 3 months versus 2 months of therapy, Outcome 4 Cumulative steroid dose.

Analysis 1.5. Comparison 1 Steroid therapy in first episode of nephrotic syndrome: 3 months versus 2 months of therapy, Outcome 5 Number with frequent relapses by 12 to 24 months stratified by definition of FRNS.

Analysis 1.6. Comparison 1 Steroid therapy in first episode of nephrotic syndrome: 3 months versus 2 months of therapy, Outcome 6 Number with frequent relapses by 12 to 24 months stratified by risk of bias for allocation concealment.

Analysis 1.7. Comparison 1 Steroid therapy in first episode of nephrotic syndrome: 3 months versus 2 months of therapy, Outcome 7 Adverse events.

Analysis 2.1. Comparison 2 Steroid therapy in first episode of nephrotic syndrome: 5 or 6 months versus 3 months of therapy, Outcome 1 Number with frequent relapses by 12 to 24 months.

Analysis 2.2. Comparison 2 Steroid therapy in first episode of nephrotic syndrome: 5 or 6 months versus 3 months of therapy, Outcome 2 Number of children relapsing by 12 to 24 months.

Analysis 2.3. Comparison 2 Steroid therapy in first episode of nephrotic syndrome: 5 or 6 months versus 3 months of therapy, Outcome 3 Mean relapse rate/patient/y.

Analysis 2.4. Comparison 2 Steroid therapy in first episode of nephrotic syndrome: 5 or 6 months versus 3 months of therapy, Outcome 4 Cumulative steroid dose.

Analysis 2.5. Comparison 2 Steroid therapy in first episode of nephrotic syndrome: 5 or 6 months versus 3 months of therapy, Outcome 5 Number with frequent relapses stratified by definition of FRNS.

Analysis 2.6. Comparison 2 Steroid therapy in first episode of nephrotic syndrome: 5 or 6 months versus 3 months of therapy, Outcome 6 Number with frequent relapses stratified by risk of bias for allocation concealment.

Analysis 2.7. Comparison 2 Steroid therapy in first episode of nephrotic syndrome: 5 or 6 months versus 3 months of therapy, Outcome 7 Number with frequent relapses stratified by risk of bias for blinding.

Analysis 2.8. Comparison 2 Steroid therapy in first episode of nephrotic syndrome: 5 or 6 months versus 3 months of therapy, Outcome 8 Number with frequent relapses stratified by risk of bias for attrition.

Analysis 2.9. Comparison 2 Steroid therapy in first episode of nephrotic syndrome: 5 or 6 months versus 3 months of therapy, Outcome 9 Adverse events.

Analysis 3.1. Comparison 3 Steroid therapy in the first episode of nephrotic syndrome: 1 month versus 2 months of therapy, Outcome 1 Number of children relapsing by 6 months.

Analysis 3.2. Comparison 3 Steroid therapy in the first episode of nephrotic syndrome: 1 month versus 2 months of therapy, Outcome 2 Number of children relapsing by 12 to 24 months. 
Analysis 3.3. Comparison 3 Steroid therapy in the first episode of nephrotic syndrome: 1 month versus 2 months of therapy, Outcome 3 Number with frequent relapses.

Analysis 3.4. Comparison 3 Steroid therapy in the first episode of nephrotic syndrome: 1 month versus 2 months of therapy, Outcome 4 Cumulative steroid dose.

Analysis 4.1. Comparison 4 Steroid therapy in the first episode of nephrotic syndrome: 12 months versus 5 months therapy, Outcome 1 Number with relapse.

Analysis 5.1. Comparison 5 Steroid therapy in the first episode of nephrotic syndrome: different total doses given over same duration, Outcome 1 Relapse at twelve months.

Analysis 5.2. Comparison 5 Steroid therapy in the first episode of nephrotic syndrome: different total doses given over same duration, Outcome 2 Number with frequently relapsing nephrotic syndrome.

Analysis 5.3. Comparison 5 Steroid therapy in the first episode of nephrotic syndrome: different total doses given over same duration, Outcome 3 Adverse effects.

Analysis 6.1. Comparison 6 Steroid therapy and Sairei-to in first episode of nephrotic syndrome, Outcome 1 Long prednisone \& Sairei-to versus standard prednisone \& Sairei-to.

Analysis 7.1. Comparison 7 Cyclosporin (CSA) and steroid therapy in first episode of childhood nephrotic syndrome, Outcome 1 Relapse by 6 months.

Analysis 7.2. Comparison 7 Cyclosporin (CSA) and steroid therapy in first episode of childhood nephrotic syndrome, Outcome 2 Relapse by 12 months.

Analysis 7.3. Comparison 7 Cyclosporin (CSA) and steroid therapy in first episode of childhood nephrotic syndrome, Outcome 3 Number needing cytotoxic agents.

Analysis 7.4. Comparison 7 Cyclosporin (CSA) and steroid therapy in first episode of childhood nephrotic syndrome, Outcome 4 Serum creatinine at end of study.

Analysis 8.1. Comparison 8 Steroid therapy in first episode of nephrotic syndrome: high dose methylprednisone versus 2 month therapy, Outcome 1 Time to first relapse.

Analysis 8.2. Comparison 8 Steroid therapy in first episode of nephrotic syndrome: high dose methylprednisone versus 2 month therapy, Outcome 2 Relapse rate.

Analysis 8.3. Comparison 8 Steroid therapy in first episode of nephrotic syndrome: high dose methylprednisone versus 2 month therapy, Outcome 3 Time to remission.

Analysis 9.1. Comparison 9 Steroid therapy and azithromycin (AZM) in the first episode of nephrotic syndrome, Outcome 1 Number of children relapsing by 6 months.

Analysis 10.1. Comparison 10 Daily prednisolone treatment during viral infections, Outcome 1 Number with relapse with infection.

Analysis 10.2. Comparison 10 Daily prednisolone treatment during viral infections, Outcome 2 Number of relapses/patient. .... Analysis 10.3. Comparison 10 Daily prednisolone treatment during viral infections, Outcome 3 Number of relapses/patient at 2 years.

Analysis 11.1. Comparison 11 Steroid therapy in relapse of nephrotic syndrome, Outcome 1 Number of children relapsing during therapy.

Analysis 11.2. Comparison 11 Steroid therapy in relapse of nephrotic syndrome, Outcome 2 Number of children with further relapses by 9 to 12 months.

Analysis 11.3. Comparison 11 Steroid therapy in relapse of nephrotic syndrome, Outcome 3 Mean relapse rate/patient/y. ...... Analysis 11.4. Comparison 11 Steroid therapy in relapse of nephrotic syndrome, Outcome 4 Mean time to relapse. ................. Analysis 11.5. Comparison 11 Steroid therapy in relapse of nephrotic syndrome, Outcome 5 Cumulative steroid dose. ........... Analysis 11.6. Comparison 11 Steroid therapy in relapse of nephrotic syndrome, Outcome 6 Mean time to remission. ............. Analysis 11.7. Comparison 11 Steroid therapy in relapse of nephrotic syndrome, Outcome 7 Serious adverse events. ............. Analysis 12.1. Comparison 12 Prolonged steroid therapy (7 months) for relapsing nephrotic syndrome, Outcome 1 Number with relapses.

Analysis 12.2. Comparison 12 Prolonged steroid therapy (7 months) for relapsing nephrotic syndrome, Outcome 2 Relapse rate/ patient/y.

Analysis 12.3. Comparison 12 Prolonged steroid therapy ( 7 months) for relapsing nephrotic syndrome, Outcome 3 Number with frequently relapsing or steroid dependent nephrotic syndrome.

Analysis 12.4. Comparison 12 Prolonged steroid therapy (7 months) for relapsing nephrotic syndrome, Outcome 4 Cumulative steroid dose.

Analysis 12.5. Comparison 12 Prolonged steroid therapy (7 months) for relapsing nephrotic syndrome, Outcome 5 Adverse effects. 
[Intervention Review]

\title{
Corticosteroid therapy for nephrotic syndrome in children
}

\author{
Deirdre Hahn¹, Elisabeth M Hodson², Narelle S Willis², Jonathan C Craig 3
}

1Department of Nephrology, The Children's Hospital at Westmead, Westmead, Australia. ${ }^{2}$ Sydney School of Public Health, The University of Sydney, Sydney, Australia. ${ }^{3}$ Cochrane Kidney and Transplant, Centre for Kidney Research, The Children's Hospital at Westmead, Westmead, Australia

Contact address: Elisabeth M Hodson, Cochrane Kidney and Transplant, Centre for Kidney Research, The Children's Hospital at Westmead, Westmead, NSW, 2145, Australia. elisabeth.hodson@health.nsw.gov.au.

Editorial group: Cochrane Kidney and Transplant Group

Publication status and date: Edited (no change to conclusions), published in Issue 9, 2015.

Citation: Hahn D, Hodson EM, Willis NS, Craig JC. Corticosteroid therapy for nephrotic syndrome in children. Cochrane Database of Systematic Reviews 2015, Issue 3. Art. No.: CD001533. DOI: 10.1002/14651858.CD001533.pub5.

Copyright @ 2015 The Cochrane Collaboration. Published by John Wiley \& Sons, Ltd.

\section{A B S T R A C T}

\section{Background}

In nephrotic syndrome protein leaks from the blood to the urine through the glomeruli resulting in hypoproteinaemia and generalised oedema. While most children with nephrotic syndrome respond to corticosteroids, $80 \%$ experience a relapsing course. Corticosteroids have reduced the mortality rate to around $3 \%$. However corticosteroids have well recognised potentially serious adverse effects such as obesity, poor growth, hypertension, diabetes mellitus, osteoporosis and behavioural disturbances. This is an update of a review first published in 2000 and updated in 2003, 2005 and 2007.

\section{Objectives}

The aim of this review was to assess the benefits and harms of different corticosteroid regimens in children with steroid-sensitive nephrotic syndrome (SSNS). The benefits and harms of therapy were studied in two groups of children 1) children in their initial episode of SSNS, and 2) children who experience a relapsing course of SSNS.

\section{Search methods}

We searched the Cochrane Renal Group's Specialised Register to 26 February 2015 through contact with the Trials Search Co-ordinator using search terms relevant to this review.

\section{Selection criteria}

Randomised controlled trials (RCTs) performed in children (three months to 18 years) in their initial or subsequent episode of SSNS, comparing different durations, total doses or other dose strategies using any corticosteroid agent.

\section{Data collection and analysis}

Two authors independently assessed risk of bias and extracted data. Results were expressed as risk ratio (RR) or mean difference (MD) with $95 \%$ confidence intervals $(\mathrm{CI})$.

\section{Main results}

Ten new studies were identified so a total of 34 studies (3033 total participants) were included in the 2015 review update. The risk of bias attributes were frequently poorly performed. Low risk of bias was reported in 18 studies for sequence generation, 16 studies for allocation concealment, seven for performance and detection bias, 15 for incomplete reporting and 16 for selective reporting. Three months or more of prednisone significantly reduced the risk of frequently relapsing nephrotic syndrome (FRNS) $(6$ studies, $582 \mathrm{children}$ : RR $0.68,95 \% \mathrm{Cl}$ 0.47 to 1.00 ) and of relapse by 12 to 24 months ( 8 studies, 741 children: RR $0.80,95 \% \mathrm{Cl} 0.64$ to 1.00 ) compared with two months. Five or six months of prednisone significantly reduced the risk of relapse ( 7 studies, 763 children: RR $0.62,95 \% \mathrm{Cl} 0.45$ to 0.85 ) but not FRNS ( 5 studies, 
591 children: RR $0.78,95 \% \mathrm{Cl} 0.50$ to 1.22 ) compared with three months. However there was significant heterogeneity in the analyses. Subgroup analysis stratified by risk of bias for allocation concealment showed that the risk for FRNS did not differ significantly between two or three months of prednisone and three to six months among studies at low risk of bias but was significantly reduced in extended duration studies compared with two or three months in studies at high risk or unclear risk of bias. There were no significant differences in the risk of adverse effects between extended duration and two or three months of prednisone. Four studies found that in children with FRNS, daily prednisone during viral infections compared with alternate-day prednisone or no treatment significantly reduced the rate of relapse.

\section{Authors' conclusions}

In this 2015 update the addition of three well-designed studies has changed the conclusion of this review. Studies of long versus shorter duration of corticosteroids have heterogeneous treatment effects, with the older high risk of bias studies tending to over-estimate the effect of longer course therapy, compared with more recently published low risk of bias studies. Among studies at low risk of bias, there was no significant difference in the risk for FRNS between prednisone given for two or three months and longer durations or total dose of therapy indicating that there is no benefit of increasing the duration of prednisone beyond two or three months in the initial episode of SSNS.

The risk of relapse in children with FRNS is reduced by the administration of daily prednisone at onset of an upper respiratory tract or viral infection. Three additional studies have increased the evidence supporting this conclusion. This management strategy may be considered for children with FRNS. A paucity of data on prednisone use in relapsing nephrotic syndrome remains. In particular there are no data from RCTs evaluating the efficacy and safety of prolonged courses of low dose alternate-day prednisone although this management strategy is recommended in current guidelines.

\section{PLAIN LANGUAGE SUMMARY}

\section{Corticosteroid therapy for children with nephrotic syndrome}

Nephrotic syndrome is a condition where the kidneys leak protein from the blood into the urine. When it is untreated, children can often die from infections. Most children, with nephrotic syndrome, respond to corticosteroid drugs (prednisone, prednisolone) reducing the risk of serious infection. However they usually have repeat episodes, which are often triggered by viral infections. Corticosteroid drugs can have serious side effects.

We looked at evidence from 34 studies enrolling 3033 children. Fourteen of 21 studies, in children with their first episode of nephrotic syndrome, evaluated prednisone for two or three months compared with longer durations. Thirteen studies evaluated different corticosteroid regimens in children with frequently relapsing disease (FRNS). Studies were of variable methodological quality with only about half of the studies at low risk of bias.

Among studies of long versus shorter duration of prednisone, older studies at high or unclear risk of bias tended to over-estimate the effect of longer course therapy compared with new studies at low risk of bias. Studies at low risk of bias found no significant differences in the risk of relapse or the development of FRNS between prednisone given for three to six months compared with two or three months. Therefore there is no benefit of increasing the duration of prednisone beyond two or three months in the initial episode of SSNS.

Based on four studies in children with frequently relapsing nephrotic syndrome, prednisone given for five to seven days at the onset of a viral infection reduces the risk of relapse.

This review updates information previously published in 2000, 2003, 2005 and 2007. The addition of three new studies evaluating different durations of prednisone in the first episode of nephrotic syndrome has changed the conclusions expressed in previous versions of this review 


\begin{tabular}{|c|c|c|c|c|c|c|c|}
\hline \multirow{4}{*}{\multicolumn{2}{|c|}{ 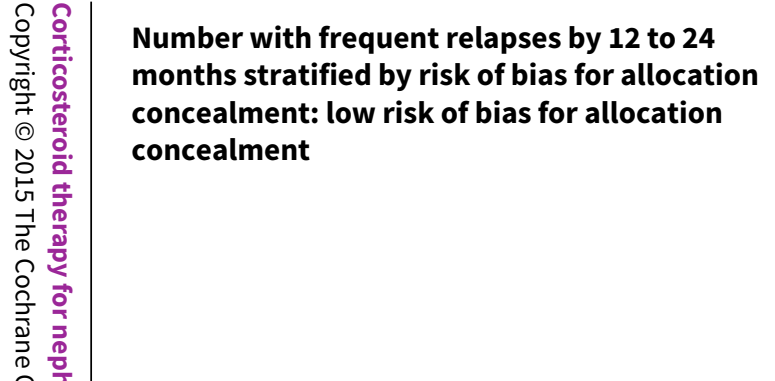 }} & \multicolumn{2}{|c|}{ Study population } & \multirow{4}{*}{$\begin{array}{l}\text { RR } 0.92 \\
(0.69 \text { to } 1.23)\end{array}$} & \multirow[t]{4}{*}{$362(3)$} & \multirow{4}{*}{$\begin{array}{l}\oplus \oplus \oplus \oplus \\
\text { high }\end{array}$} & \multirow{4}{*}{ 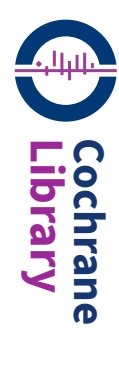 } \\
\hline & & 359 per 1000 & $\begin{array}{l}330 \text { per } 1000 \\
(247 \text { to } 441)\end{array}$ & & & & \\
\hline & & \multicolumn{2}{|l|}{ Moderate } & & & & \\
\hline & & 348 per 1000 & $\begin{array}{l}320 \text { per } 1000 \\
(240 \text { to } 428)\end{array}$ & & & & \\
\hline$\overline{\bar{\sigma}}$ & \multirow{4}{*}{$\begin{array}{l}\text { Number with frequent relapses by } 12 \text { to } 24 \\
\text { months stratified by risk of bias for allocation } \\
\text { concealment: unclear or high risk of bias for } \\
\text { allocation bias }\end{array}$} & Study popula & & \multirow{4}{*}{$\begin{array}{l}\text { RR } \mathbf{0 . 4 5} \\
\text { (0.26 to } 0.77)\end{array}$} & \multirow[t]{4}{*}{$220(3)$} & \multirow{4}{*}{$\begin{array}{l}\oplus \oplus \oplus \ominus \\
\text { moderate }^{1}\end{array}$} & 2 \\
\hline 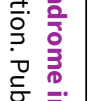 & & 357 per 1000 & $\begin{array}{l}\mathbf{1 6 1} \text { per } \mathbf{1 0 0 0} \\
\text { (93 to } 275 \text { ) }\end{array}$ & & & & 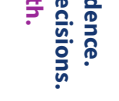 \\
\hline 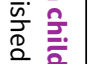 & & \multicolumn{2}{|l|}{ Moderate } & & & & \\
\hline 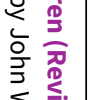 & & 371 per 1000 & $\begin{array}{l}\mathbf{1 6 7} \text { per } 1000 \\
\text { (96 to } 286)\end{array}$ & & & & \\
\hline$\underbrace{\frac{\pi}{2}}_{\infty} \leqslant$ & \multirow[t]{4}{*}{ Adverse events: psychological disorders } & \multicolumn{2}{|c|}{ Study population } & \multirow{4}{*}{$\begin{array}{l}\text { RR } 2.18 \\
\text { (0.43 to } 11.13)\end{array}$} & \multirow[t]{4}{*}{$233(3)$} & \multirow{4}{*}{$\begin{array}{l}\oplus \oplus \oplus \ominus \\
\text { low } 1,3\end{array}$} & \\
\hline$\frac{n}{2}$ & & 18 per 1000 & $\begin{array}{l}40 \text { per } 1000 \\
(8 \text { to } 202)\end{array}$ & & & & \\
\hline & & \multicolumn{2}{|l|}{ Moderate } & & & & \\
\hline & & 0 per 1000 & $\begin{array}{l}\text { O per } 1000 \\
(0 \text { to } 0)\end{array}$ & & & & \\
\hline & \multirow[t]{4}{*}{ Adverse events: hypertension } & \multicolumn{2}{|c|}{ Study population } & \multirow{4}{*}{$\begin{array}{l}\text { RR } 1.79 \\
(0.47 \text { to } 6.86)\end{array}$} & \multirow[t]{4}{*}{$456(6)$} & \multirow{4}{*}{$\begin{array}{l}\oplus \oplus \oplus \ominus \\
\text { moderate }^{1}\end{array}$} & \\
\hline & & 60 per 1000 & $\begin{array}{l}107 \text { per } 1000 \\
(28 \text { to } 410)\end{array}$ & & & & $\begin{array}{l}\hat{\wp} \\
\frac{⿳}{n}\end{array}$ \\
\hline & & \multicolumn{2}{|l|}{ Moderate } & & & & סֶּ \\
\hline & & 0 per 1000 & $\begin{array}{l}0 \text { per } 1000 \\
(0 \text { to } 0)\end{array}$ & & & & 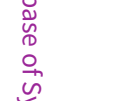 \\
\hline & \multirow[t]{2}{*}{ Adverse events: eye complications } & Study popula & & \multirow{2}{*}{$\begin{array}{l}\text { RR } 0.32 \\
(0.07 \text { to } 1.42)\end{array}$} & \multirow[t]{2}{*}{$400(5)$} & \multirow{2}{*}{$\begin{array}{l}\oplus \oplus \oplus \ominus \\
\text { moderate }^{1}\end{array}$} & 3 \\
\hline & & 43 per 1000 & 14 per 1000 & & & & 涩 \\
\hline
\end{tabular}




\begin{tabular}{ll} 
& (3 to 62) \\
\hline Moderate & \\
\hline 0 per 1000 & $\begin{array}{l}\text { O per } 1000 \\
(0 \text { to } 0)\end{array}$ \\
\hline
\end{tabular}

${ }^{\star}$ The basis for the assumed risk (e.g. the median control group risk across studies) is provided in footnotes. The corresponding risk (and its $95 \% \mathrm{Cl}$ ) is based on the assumed risk in the comparison group and the relative effect of the intervention (and its $95 \% \mathrm{Cl}$ ).

Cl: Confidence interval; RR: Risk ratio;

GRADE Working Group grades of evidence

High quality: Further research is very unlikely to change our confidence in the estimate of effect.

Moderate quality: Further research is likely to have an important impact on our confidence in the estimate of effect and may change the estimate.

Low quality: Further research is very likely to have an important impact on our confidence in the estimate of effect and is likely to change the estimate.

Very low quality: We are very uncertain about the estimate.

1 Some studies at high or unclear risk of bias

2 Significant heterogeneity between studies

3 Few studies included in analysis

Summary of findings 2. Steroid therapy in first episode of nephrotic syndrome: five or six months versus three months for nephrotic syndrome in children

Steroid therapy in first episode of nephrotic syndrome: 5 to 6 months versus 3 months for nephrotic syndrome in children

Patient or population: patients with nephrotic syndrome in children

Settings:

Intervention: steroid therapy in first episode of nephrotic syndrome: 5 to 6 months versus 3 months

\begin{tabular}{|c|c|c|c|c|c|c|}
\hline \multirow[t]{2}{*}{ Outcomes } & \multicolumn{2}{|c|}{ Illustrative comparative risks* $(95 \% \mathrm{CI})$} & \multirow{2}{*}{$\begin{array}{l}\text { Relative effect } \\
(95 \% \mathrm{CI})\end{array}$} & \multirow{2}{*}{$\begin{array}{l}\text { No of Partici- } \\
\text { pants } \\
\text { (studies) }\end{array}$} & \multirow{2}{*}{$\begin{array}{l}\text { Quality of the } \\
\text { evidence } \\
\text { (GRADE) }\end{array}$} & \multirow[t]{2}{*}{ Comments } \\
\hline & Assumed risk & Corresponding risk & & & & \\
\hline \multirow{2}{*}{$\begin{array}{l}\text { Number with frequent relapses by } 12 \text { to } \\
24 \text { months }\end{array}$} & \multicolumn{2}{|c|}{ Study population } & \multirow{2}{*}{$\begin{array}{l}\mathbf{R R} \mathbf{0 . 7 8} \\
(0.5 \text { to } 1.22)\end{array}$} & \multirow[t]{2}{*}{$591(5)$} & \multirow{2}{*}{$\begin{array}{l}\oplus \oplus \ominus \ominus \\
\text { low } 1\end{array}$} & \\
\hline & 363 per 1000 & 283 per 1000 & & & & \\
\hline
\end{tabular}




\begin{tabular}{|c|c|c|c|c|c|c|}
\hline \multirow{7}{*}{ 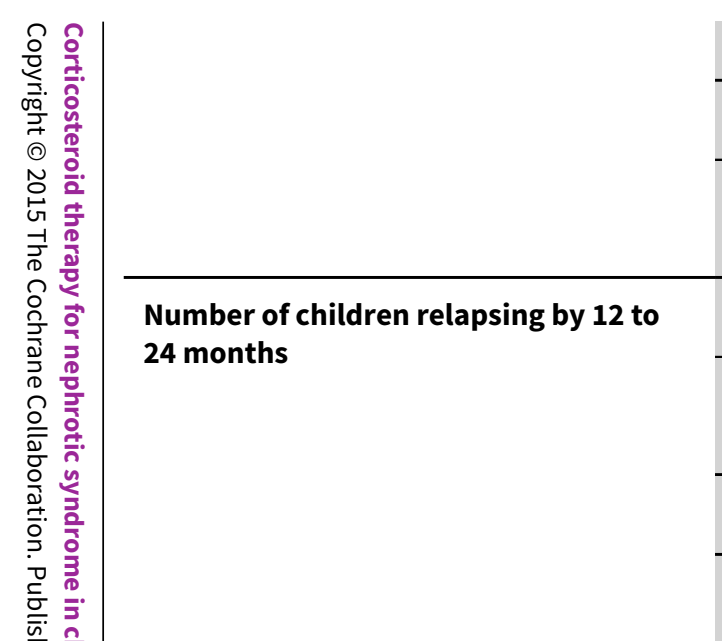 } & \multicolumn{2}{|r|}{ (182 to 443$)$} & & & & \multirow{4}{*}{ 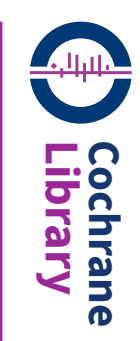 } \\
\hline & \multicolumn{2}{|l|}{ Moderate } & & & & \\
\hline & 393 per 1000 & $\begin{array}{l}\mathbf{3 0 7} \text { per } \mathbf{1 0 0 0} \\
\text { (196 to } 479)\end{array}$ & & & & \\
\hline & \multicolumn{2}{|c|}{ Study population } & \multirow{4}{*}{$\begin{array}{l}\mathbf{R R} \mathbf{0 . 6 2} \\
(0.45 \text { to } 0.85 \text { ) }\end{array}$} & \multirow[t]{4}{*}{$763(7)$} & \multirow{4}{*}{$\begin{array}{l}\oplus \oplus \ominus \ominus \\
\text { low } \mathbf{w}^{1,2}\end{array}$} & \\
\hline & 694 per 1000 & $\begin{array}{l}\mathbf{4 3 0} \text { per } \mathbf{1 0 0 0} \\
\text { (312 to } 590)\end{array}$ & & & & \multirow{7}{*}{ 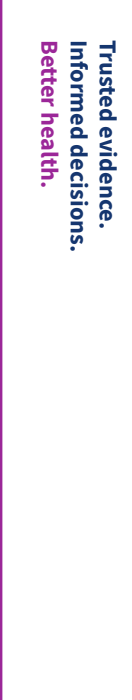 } \\
\hline & \multicolumn{2}{|l|}{ Moderate } & & & & \\
\hline & 703 per 1000 & $\begin{array}{l}\mathbf{4 3 6} \text { per } \mathbf{1 0 0 0} \\
\text { (316 to } 598)\end{array}$ & & & & \\
\hline \multirow{4}{*}{$\begin{array}{l}\text { Subgroup analysis by risk of bias for } \\
\text { number with frequent relapses: low risk } \\
\text { of bias for allocation concealment }\end{array}$} & \multicolumn{2}{|c|}{ Study population } & \multirow{4}{*}{$\begin{array}{l}\text { RR } 1 \\
\text { (0.74 to } 1.34)\end{array}$} & \multirow[t]{4}{*}{$377(3)$} & \multirow{4}{*}{$\begin{array}{l}\oplus \oplus \oplus \oplus \\
\text { high }\end{array}$} & \\
\hline & 438 per 1000 & $\begin{array}{l}\mathbf{4 3 8} \text { per } 1000 \\
(324 \text { to } 587)\end{array}$ & & & & \\
\hline & \multicolumn{2}{|l|}{ Moderate } & & & & \\
\hline & 441 per 1000 & $\begin{array}{l}\mathbf{4 4 1} \text { per } 1000 \\
(326 \text { to } 591)\end{array}$ & & & & \\
\hline \multirow{4}{*}{$\begin{array}{l}\text { Subgroup analysis by risk of bias for } \\
\text { number with frequent relapses: Unclear } \\
\text { or high risk of bias for allocation con- } \\
\text { cealment }\end{array}$} & \multicolumn{2}{|c|}{ Study population } & \multirow{4}{*}{$\begin{array}{l}\text { RR } 0.36 \\
\text { (0.18 to } 0.72)\end{array}$} & \multirow[t]{4}{*}{$214(2)$} & \multirow{4}{*}{$\begin{array}{l}\oplus \oplus \oplus \ominus \\
\text { moderate }\end{array}$} & \\
\hline & 234 per 1000 & $\begin{array}{l}84 \text { per } 1000 \\
\text { (42 to } 168 \text { ) }\end{array}$ & & & & \\
\hline & \multicolumn{2}{|l|}{ Moderate } & & & & \\
\hline & 185 per 1000 & $\begin{array}{l}67 \text { per } 1000 \\
\text { (33 to } 133)\end{array}$ & & & & $\sigma$ \\
\hline \multirow[t]{3}{*}{ Adverse events: hypertension } & \multicolumn{2}{|c|}{ Study population } & \multirow{3}{*}{$\begin{array}{l}\text { RR } 1.37 \\
(0.91 \text { to } 2.05)\end{array}$} & \multirow[t]{3}{*}{$636(5)$} & \multirow{3}{*}{$\begin{array}{l}\oplus \oplus \oplus \ominus \\
\text { moderate } 2\end{array}$} & 岕 \\
\hline & 111 per 1000 & $\begin{array}{l}\mathbf{1 5 3} \text { per } 1000 \\
(101 \text { to } 229)\end{array}$ & & & & 竞 \\
\hline & Moderate & & & & & 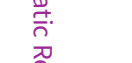 \\
\hline
\end{tabular}




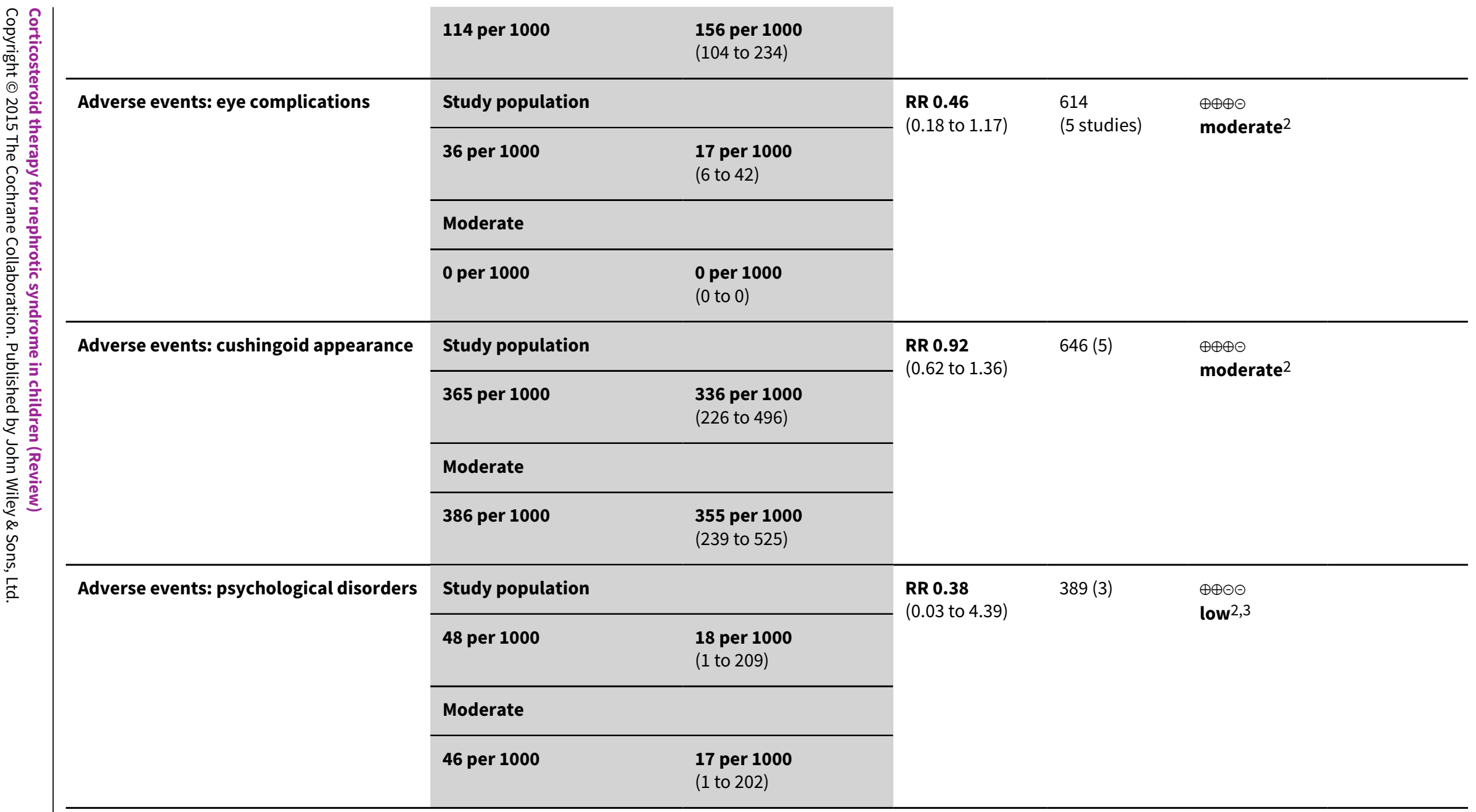

*The basis for the assumed risk (e.g. the median control group risk across studies) is provided in footnotes. The corresponding risk (and its $95 \% \mathrm{Cl}$ ) is based on the assumed risk in the comparison group and the relative effect of the intervention (and its $95 \% \mathrm{CI}$ ).

Cl: Confidence interval; RR: Risk ratio

GRADE Working Group grades of evidence

High quality: Further research is very unlikely to change our confidence in the estimate of effect.

Moderate quality: Further research is likely to have an important impact on our confidence in the estimate of effect and may change the estimate.

Low quality: Further research is very likely to have an important impact on our confidence in the estimate of effect and is likely to change the estimate.

Very low quality: We are very uncertain about the estimate. 

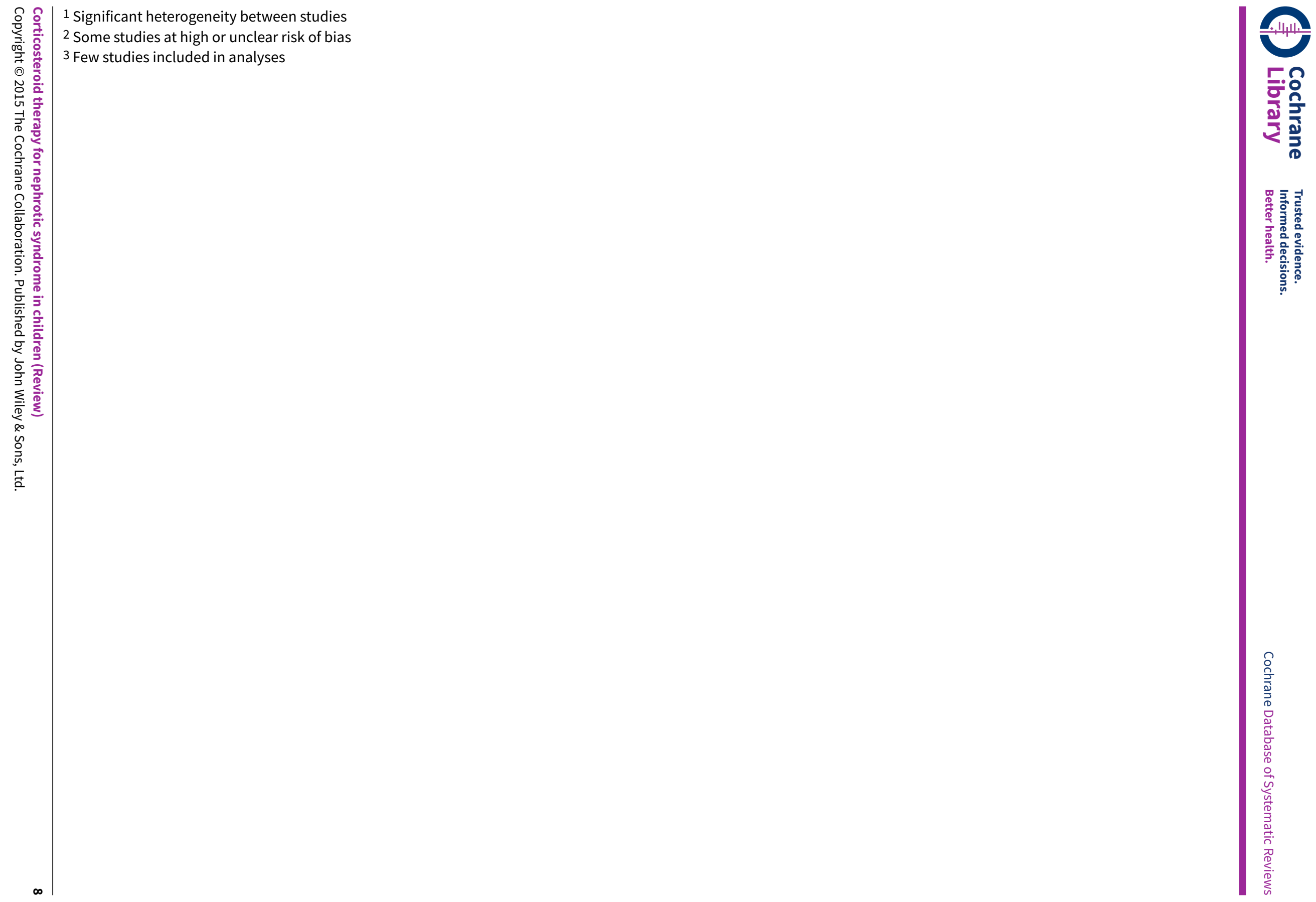


\section{B A C K G R O U N D}

\section{Description of the condition}

Nephrotic syndrome is a well-recognised chronic illness in childhood. The characteristic features, including oedema, proteinuria and hypoalbuminaemia, result from alterations of the perm-selectivity barrier of the glomerular capillary wall. The reported incidence is 2 to $7 / 100,000$ children, with a prevalence of 16/100,000 (Eddy 2003). Recent prospective studies revealed an incidence of 1.15 to 2.1/100,000 children/year (El Bakkali 2011).The incidence of nephrotic syndrome is higher in Asian (McKinney 2001), African-American (Srivastava 1999) and Arab children (Elzouki 1984). Most children have minimal change disease, in which changes on light microscopy are minor or absent, and respond to corticosteroid agents. Despite the overall incidence of childhood nephrotic syndrome remaining relatively stable over the last three decades, the histological pattern appears to be changing with an increase in the incidence of focal and segmental glomerulosclerosis (FSGS), even after adjustment for biopsy practices (Bonilla-Felix 1999; Gulati 1999; Srivastava 1999). The histological variant and response to immunosuppressive treatment may be related to ethnicity (Eddy 2003). Steroidsensitive nephrotic syndrome (SSNS) is less common in African and African-American children, and in South Africa $7.2 \%$ of 236 African children had SSNS compared with $62 \%$ of 286 Indian children (Bhimma 1997). The pathogenesis of SSNS remains unknown but appears to be related to abnormalities in T-cell and B-cell regulation. About $80 \%$ of children who respond to corticosteroids experience a relapsing course with recurrent episodes of oedema and proteinuria (Koskimies 1982; Tarshish 1997). The complications of nephrotic syndrome are related to effects of the disease itself, and adverse effects related to corticosteroid therapy and corticosteroid sparing agents. Children with nephrotic syndrome, which is resistant to therapy, are at increased risk of bacterial infection, characteristically resulting in peritonitis, cellulitis or septicaemia, of thromboembolic phenomena and of protein calorie malnutrition. Before antibiotics became available, two thirds of children with nephrotic syndrome died (Arneil 1971).The survivors remitted spontaneously after several months. Mortality rates fell to $35 \%$ with the introduction of sulphonamides and penicillin (Arneil 1971) and fell further with the use of corticosteroid medications.

\section{Description of the intervention}

Corticosteroids have been used to treat childhood nephrotic syndrome since 1950 when large doses of adrenocorticotrophic hormone (ACTH) and cortisone given for two to three weeks were found to induce diuresis with loss of oedema and proteinuria (Arneil 1971). Corticosteroid usage has reduced the mortality rate in childhood nephrotic syndrome to around $3 \%$, with infection remaining the most important cause of death (ISKDC 1984). Of children who present with their first episode of nephrotic syndrome, approximately $80 \%$ will achieve remission with corticosteroid therapy (Koskimies 1982). Because of this dramatic before-after evidence, oral corticosteroids are the first-line treatment of a child presenting with idiopathic nephrotic syndrome and no randomised controlled prospective studies of corticosteroids compared to placebo were carried out. The achievement of remission with corticosteroid therapy determines long term prognosis for kidney function irrespective of kidney histology (Niaudet 2009). However corticosteroids have known adverse effects. Major complications related to prolonged corticosteroid use in nephrotic syndrome include growth impairment, particularly with steroid therapy administered daily (Hyams 1988), cataracts (Ng 2001) and excessive weight gain or obesity (Rüth 2005).Two recent studies (Mishra 2010; Neuhaus 2010) highlight the impact of psychological and behavioural abnormalities related to corticosteroid therapy. Anxiety, depression, emotional lability, aggressive behaviour and attention problems had already developed with completion of 12 weeks of therapy (Mishra 2010). Neuhaus 2010 demonstrated family background, particularly maternal distress, reduced quality of life and psychosocial adjustment. Adverse effects are particularly prevalent in those children who relapse frequently and thus require multiple courses of corticosteroids.

\section{How the intervention might work}

The pharmacology and pharmacodynamics of corticosteroids in SSNS are not fully understood (Mehls 2011). It is widely believed the main effect is through the regulation of nuclear gene expression via the cytosolic glucocorticoid receptor, which activates genes for anti-inflammatory cytokines and suppresses genes for proinflammatory cytokines. Glucocorticoids are lipid soluble and can easily pass through cell membranes. This process takes several hours. More recently research had identified corticosteroid effects, which are independent of nuclear gene transcription and occur earlier. At high glucocorticoid doses, suppression of T-cell function occurs. Corticosteroids also act directly to stabilise the podocyte cytoskeleton.

\section{Why it is important to do this review}

The original treatment schedules for childhood nephrotic syndrome were developed in an ad hoc manner. The International Study of Kidney Disease in Children (ISKDC) was established in 1966 and determined by consensus a regimen of daily corticosteroids for four weeks followed by corticosteroids given on three consecutive days out of seven for four weeks (Arneil 1971). Since then many physicians have used regimens involving periods of daily followed by alternate-day or intermittent therapy and several randomised controlled trials (RCTs) have investigated different durations and total corticosteroid therapy doses in an effort to delineate the optimal doses and durations of corticosteroid therapy that are most beneficial and least harmful. These have been evaluated in previous versions of this systematic review. However despite these data there remains no consensus on the most appropriate corticosteroid regimen to achieve and maintain remission with the least adverse effects. Therefore the 2015 update of this review has been undertaken to identify further RCTs, which compare different corticosteroid regimens in the initial episode of SSNS and in relapsing disease.

\section{OB JECTIVES}

The aim of this review was to assess the benefits and harms of different corticosteroid regimens in children with SSNS. The benefits and harms of therapy were studied in two groups of children:

\section{Children in their initial episode of SSNS}

2. Children who experience a relapsing course of SSNS. 


\section{METHODS}

\section{Criteria for considering studies for this review}

\section{Types of studies}

All RCTs and quasi-RCTs, in which different doses, dose strategies, routes of administration and durations of treatment with prednisone, prednisolone or other corticosteroid agent are compared in the treatment of SSNS in children, were included.

\section{Types of participants}

\section{Inclusion criteria}

Children aged three months to 18 years with SSNS (i.e. become oedema free with urine protein $\leq 1+$ on dipstick, urinary protein/ creatinine ratio $\leq 20 \mathrm{mg} / \mathrm{mmol}$ or $\leq 4 \mathrm{mg} / \mathrm{m}^{2} / \mathrm{h}$ for three consecutive days while receiving corticosteroid therapy). A kidney biopsy diagnosis of minimal change disease was not required for inclusion of the study.

- Children with initial episode of SSNS

- Children with relapsing SSNS

\section{Exclusion criteria}

- Children with steroid-resistant nephrotic syndrome (failure to achieve remission following four weeks or more of prednisone at $60 \mathrm{mg} / \mathrm{m}^{2} / \mathrm{d}$ ) or congenital nephrotic syndrome

- Children with other kidney or systemic forms of nephrotic syndrome defined on kidney biopsy, clinical features or serology (e.g. idiopathic membranous glomerulonephritis, mesangiocapillary glomerulonephritis, post-infectious glomerulonephritis, Henoch-Schönlein nephritis, systemic lupus erythematosus)

\section{Types of interventions}

Prednisone, prednisolone or other corticosteroid medication given orally or intravenously. The following aspects of the corticosteroid regimens were considered.

- Shorter duration compared with two months of corticosteroid treatment

- Longer durations compared with two or three months of corticosteroid treatment

- Comparisons of different doses of corticosteroid medication given for induction of a remission

- Comparisons of other regimens of corticosteroid therapy

- Different corticosteroid agents (e.g. deflazacort, methylprednisolone) compared with standard agents (e.g. prednisone, prednisolone)

- Comparisons of daily, alternate-day or intermittent administration of corticosteroid medication. Intermittent administration refers to the administration of corticosteroids on three consecutive days of seven days

- Single daily dose compared with divided daily doses of corticosteroid medication

- Corticosteroid medication given with other agents for the first episode of steroid-responsive nephrotic syndrome.

\section{Types of outcome measures}

\section{Primary outcomes}

1. The numbers of children with and without relapse at six months, 12 months and 24 months after completion of treatment.

2. The number of children who developed frequently relapsing nephrotic syndrome.

\section{Secondary outcomes}

1. The number of children who required other immunosuppressive therapy because of steroid toxicity

2. Mean relapse rates/patient

3. Serious adverse events including reduced growth rates, hypertension, cataracts/glaucoma, psychological disorders, infections, thromboses and osteoporosis

4. Cumulative corticosteroid dosage

\section{Search methods for identification of studies}

\section{Electronic searches}

We searched the Cochrane Renal Group's Specialised Register up to 26 February 2015 through contact with the Trials Search Coordinator using search terms relevant to this review. The Cochrane Renal Group's Specialised Register contains studies identified from the following sources.

1. Monthly searches of the Cochrane Central Register of Controlled Trials (CENTRAL)

2. Weekly searches of MEDLINE OVID SP

3. Handsearching of renal-related journals and the proceedings of major renal conferences

4. Searching of the current year of EMBASE OVID SP

5. Weekly current awareness alerts for selected renal journals

6. Searches of the International Clinical Trials Register (ICTRP) Search Portal and ClinicalTrials.gov.

Studies contained in the Specialised Register are identified through search strategies for CENTRAL, MEDLINE, and EMBASE based on the scope of the Cochrane Renal Group. Details of these strategies, as well as a list of handsearched journals, conference proceedings and current awareness alerts, are available in the Specialised Register section of information about the Cochrane Renal Group.

See Appendix 1 for search terms used in strategies for this review.

\section{Searching other resources}

1. Reference lists of nephrology textbooks, review articles and relevant studies and CD-ROMs and abstract books from nephrology meetings.

2. Letters seeking information about unpublished or incomplete studies to investigators known to be involved in previous studies.

3. Conference proceedings of meetings of the International Pediatric Nephrology Association and European Society for Paediatric Nephrology. 


\section{Data collection and analysis}

\section{Selection of studies}

The initial review was undertaken by four authors. The titles and abstracts were screened by two authors who discarded studies that were not relevant (i.e. studies of lipid lowering agents) although studies and reviews that could have included relevant data or information on studies were retained initially. Three authors independently assessed abstracts, and if necessary the full text, to determine which studies satisfied the characteristics required for inclusion. The 2003, 2005 and 2007 updates were undertaken by three authors (EH, NW, JC).

This 2015 update was undertaken by four authors (DH, EH, NW, JC). Potentially relevant studies were initially determined by two authors from titles and abstracts. Full text articles of potentially eligible articles were reviewed for eligibility by two authors.

\section{Data extraction and management}

Data extraction and assessment of risk of bias were performed by two authors using standardised data extraction forms. Studies in languages other than English were translated before data extraction. Where more than one report of a study was identified, data were extracted from all reports. Where there were discrepancies between reports, data from the primary source was used. Study authors were contacted for additional information about studies where possible.

\section{Assessment of risk of bias in included studies}

For this update, the following items were assessed during the risk of bias assessment tool (Higgins 2011).

- Was there adequate sequence generation (selection bias)?

- Was allocation adequately concealed (selection bias)?

- Was knowledge of the allocated interventions adequately prevented during the study (detection bias)?

* Participants and personnel

* Outcome assessors

- Were incomplete outcome data adequately addressed (attrition bias)?

- Are reports of the study free of suggestion of selective outcome reporting (reporting bias)?

- Was the study apparently free of other problems that could put it at a risk of bias?

\section{Measures of treatment effect}

For dichotomous outcomes (relapse or no relapse, side effects) the risk ratio (RR) for individual studies were calculated and summary statistics estimated using the random effects model and results compared to those obtained using a fixed effects model. Where continuous scales of measurement were used to assess the effects of treatment (cumulative steroid therapy, relapse rate), these data were analysed as the mean difference (MD) or standardised mean difference (SMD) if different scales had been used. The time to relapse was not included since many children did not experience relapse so the data would be biased.

\section{Unit of analysis issues}

Data from cross-over studies were included in the meta-analyses if separate data for the first part of the study were available. Otherwise results of cross-over studies were reported in the text only.

\section{Dealing with missing data}

We aimed to analyse available data in meta-analyses using ITT data. However, where ITT data were not provided, or additional information could not be obtained from authors, available published data were used in the analyses.

\section{Assessment of heterogeneity}

Heterogeneity was analysed using a Chi2 test with $\mathrm{N}-1$ degrees of freedom and an alpha of 0.05 used for statistical significance and with the $1^{2}$ test (Higgins 2003). $1^{2}$ values of $25 \%, 50 \%$ and $75 \%$ correspond to low, medium and high levels of heterogeneity.

\section{Assessment of reporting biases}

The search strategy used aimed to reduce publication bias caused by lack of publication of studies with negative results. Where there were several publications on the same study, all reports were reviewed to ensure that all details of methods and results were included to reduce the risk of selective outcome reporting bias.

\section{Data synthesis}

Data were combined using random effects model for dichotomous and continuous data.

\section{Subgroup analysis and investigation of heterogeneity}

Subgroup analysis was used to investigate between study differences based on risk of bias, differences between definitions of FRNS and different durations of treatment in the experimental group in studies comparing two months with three or more months of prednisone.

\section{Sensitivity analysis}

Where a single study differed considerably from the other studies in the meta-analysis, this study was temporarily excluded to determine whether its removal altered the results of the metaanalysis.

\section{RESULTS}

\section{Description of studies}

\section{Results of the search}

Search results are shown in Figure 1. 
Figure 1. Study flow diagram.

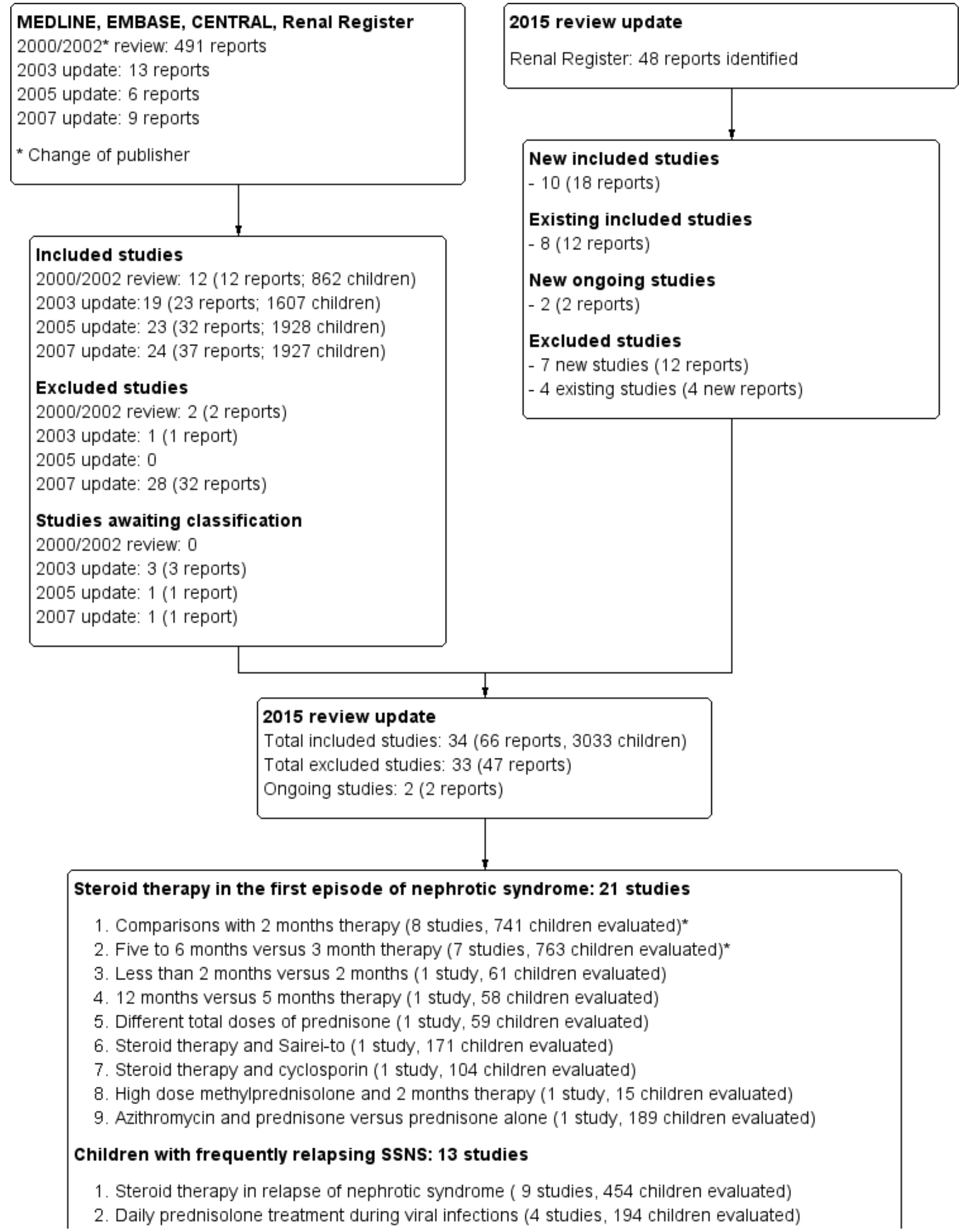


Figure 1. (Continued)

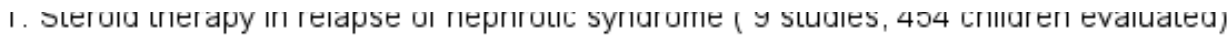
2. Daily prednisolone treatment during viral infections (4 studies, 194 children evaluated)
* One study had children in each comparison group

For this latest update our search (to 26 February 2015) identified 48 potentially relevant reports. Of these, nine new studies (16 reports) (Abeyagunawardena 2008; Abeyagunawardena 2014; Gulati 2009; Liern 2008; Mishra 2012; Sinha 2014; Teeninga 2013; Yoshikawa 2014; Zhang 2014) were included. One study awaiting assessment (Mocan 1999) was also included. Our search also identified two studies that are underway; no results were yet available to include in our analysis (PREDNOS Study 2013, PREDNOS 2 Study 2014). We also found 12 reports of nine previously included studies (APN 1988; APN 1993; Bagga 1999; Broyer 1997; Ekka 1997; Hiraoka 2000; Norero 1996; Pecoraro 2003; Yoshikawa 1998). This update includes 34 studies (66 reports) that involved a total of 3033 participants.

For the search results of our previous reviews please see (Hodson 2002; Hodson 2003; Hodson 2005; Hodson 2007).

\section{Included studies}

The 34 included studies were divided into groups according to comparisons of corticosteroid regimens. Most studies used prednisone or prednisolone. For ease of reading, the term "prednisone" has been used in the text for both medications.

\section{Prednisone treatment in first episode of nephrotic syndrome}

Three months or more versus two months of therapy (741 evaluated children)

Seven studies (APN 1993; Bagga 1999; Jayantha 2002a; Ksiazek 1995; Norero 1996; Satomura 2001; Ueda 1988; Yoshikawa 2014) compared therapies of two months duration with regimens of three months or more. In all of these studies except Satomura 2001 , increased duration of treatment resulted in increased total prednisone dose compared with the control group. Satomura 2001 compared three months of treatment with two months weeks using the same total dose of prednisone in each group. In Ksiazek 1995, which compared three different regimens, data from the two month therapy group and the experimental group treated for six months (experimental group 1) were included in the meta-analysis. Norero 1996 excluded those children who became steroid dependent.

\section{Five to six months versus three months of therapy (763 evaluated} children)

Seven studies (Hiraoka 2003; Ksiazek 1995; Mishra 2012, Pecoraro 2003; Sharma 2000; Sinha 2014; Teeninga 2013) compared five or six months of prednisone with three months of therapy. In all studies except Teeninga 2013, increased duration of prednisone resulted in increased total prednisone dose compared with the control group. Teeninga 2013 compared three months with six months therapy, using the same total dose of prednisone in both groups. From Ksiazek 1995, data from the experimental groups treated for three months (experimental group 2) and six months (experimental group 1) were included in this analysis. Pecoraro 2003 had three groups - a control group treated for three months and two experimental groups treated for six months with different total doses of prednisone. Only the control group and treatment group 1 were included in the meta-analysis.
Less than two months versus two months of therapy (61 evaluated children)

APN 1988 compared less than the two month of prednisone with two months.

\section{2 months versus five months of therapy (58 evaluated children)}

Kleinknecht 1982 compared five months of prednisone with one year of therapy; the timing of the follow-up period in relation to the duration of initial therapy was not stated.

\section{Different total doses of prednisone (59 evaluated children)}

Hiraoka 2000 compared different total doses of prednisone given for three months.

\section{Prednisone and Sairei-to therapy (171 evaluated children)}

Yoshikawa 1998 compared two months of prednisone with 4.5 months but both groups received the Chinese herb, Sairei-to. The assumption was made that the effect of the herb would be the same in both treatment groups. However because this assumption may not be correct, this study was considered separately from other studies comparing different durations of prednisone.

\section{Prednisone and cyclosporin therapy (104 evaluated children)}

APN 1999 compared three months of prednisone plus two months of cyclosporin with three months of prednisone only.

\section{High dose oral methylprednisolone therapy (15 evaluated children)}

Mocan 1999 compared high dose oral methylprednisolone given over two weeks with six months of prednisone therapy.

\section{Prednisone and azithromycin therapy (211 evaluated children)}

Zhang 2014 compared the addition of azithromycin to prednisone with prednisone alone at initiation of therapy in the first episode of nephrotic syndrome.

\section{Relapsing nephrotic syndrome}

Daily prednisone treatment during viral infections (194 evaluated children)

Three studies (Abeyagunawardena 2008; Gulati 2009; Mattoo 2000) compared daily with alternate-day prednisone to prevent relapse during viral infections in children with SSNS receiving alternateday prednisone. One study (Abeyagunawardena 2014) compared daily prednisone with placebo to prevent relapse during upper respiratory tract infections in children with SSNS off prednisone.

\section{Relapsing nephrotic syndrome: other interventions (454 evaluated} children)

Nine studies investigated relapsing SSNS (APN 1981; Broyer 1997; Ekka 1997; Imbasciati 1985; ISKDC 1984; Jayantha 2002b; Leisti 1978; Li 1994; Liern 2008). Ekka 1997 and Li 1994 compared single daily with three times/day dosage of prednisone. The remaining studies explored different treatment regimens aimed at 
inducing remission, maintaining remission or both. Jayantha 2002b excluded children with steroid dependent nephrotic syndrome. Imbasciati 1985 and Jayantha 2002b included children with infrequently and frequently relapsing SSNS.

\section{Excluded studies}

In total, we excluded 34 studies (66 reports) after full text assessment for this review. Of the 34 excluded studies, five were not
RCTs and 29 were RCTs involving non-corticosteroid interventions in children with SSNS.

\section{Risk of bias in included studies}

Risk of bias assessments were performed using Cochrane's risk of bias assessment tool (Appendix 2). Summaries of risk of bias assessments are shown in Figure 2; Figure 3.

Figure 2. Risk of bias graph: review authors' judgements about each risk of bias item presented as percentages across all included studies.

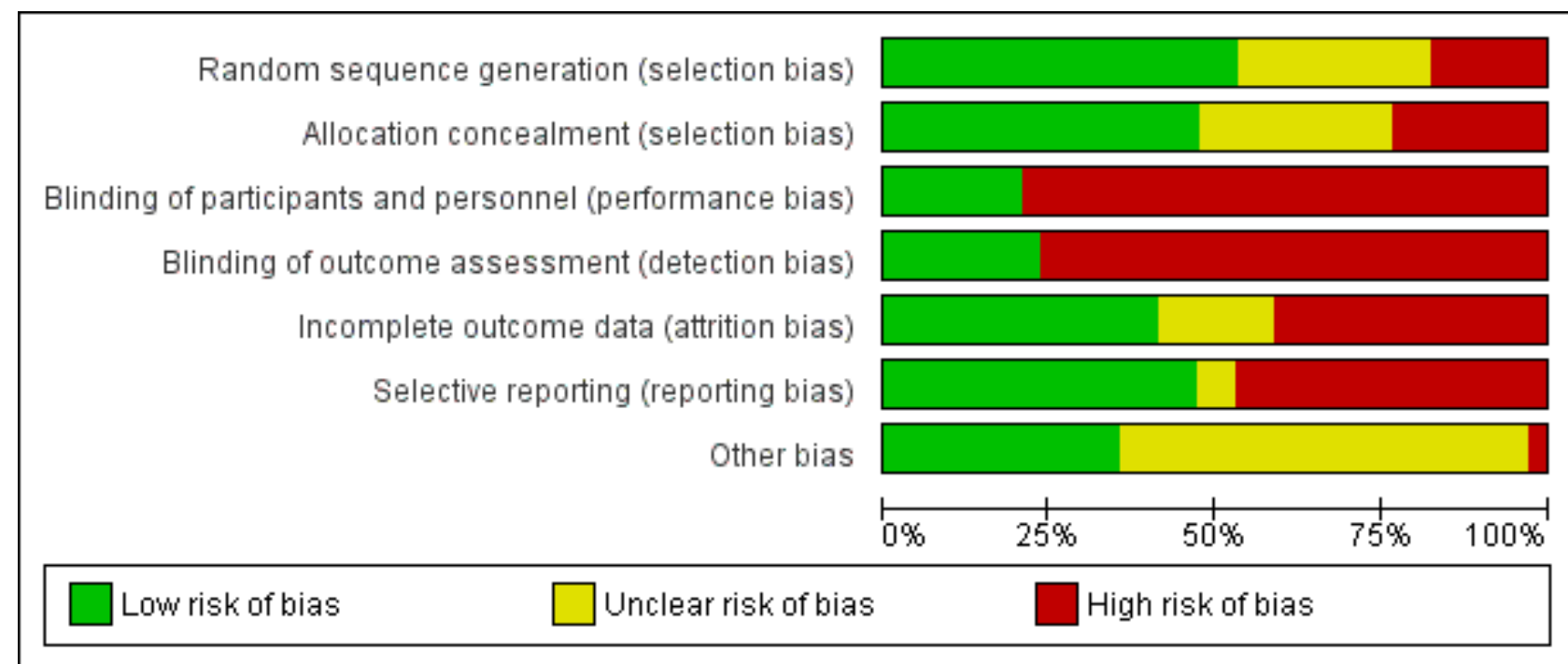


Figure 3. Risk of bias summary: review authors' judgements about each risk of bias item for each included study.

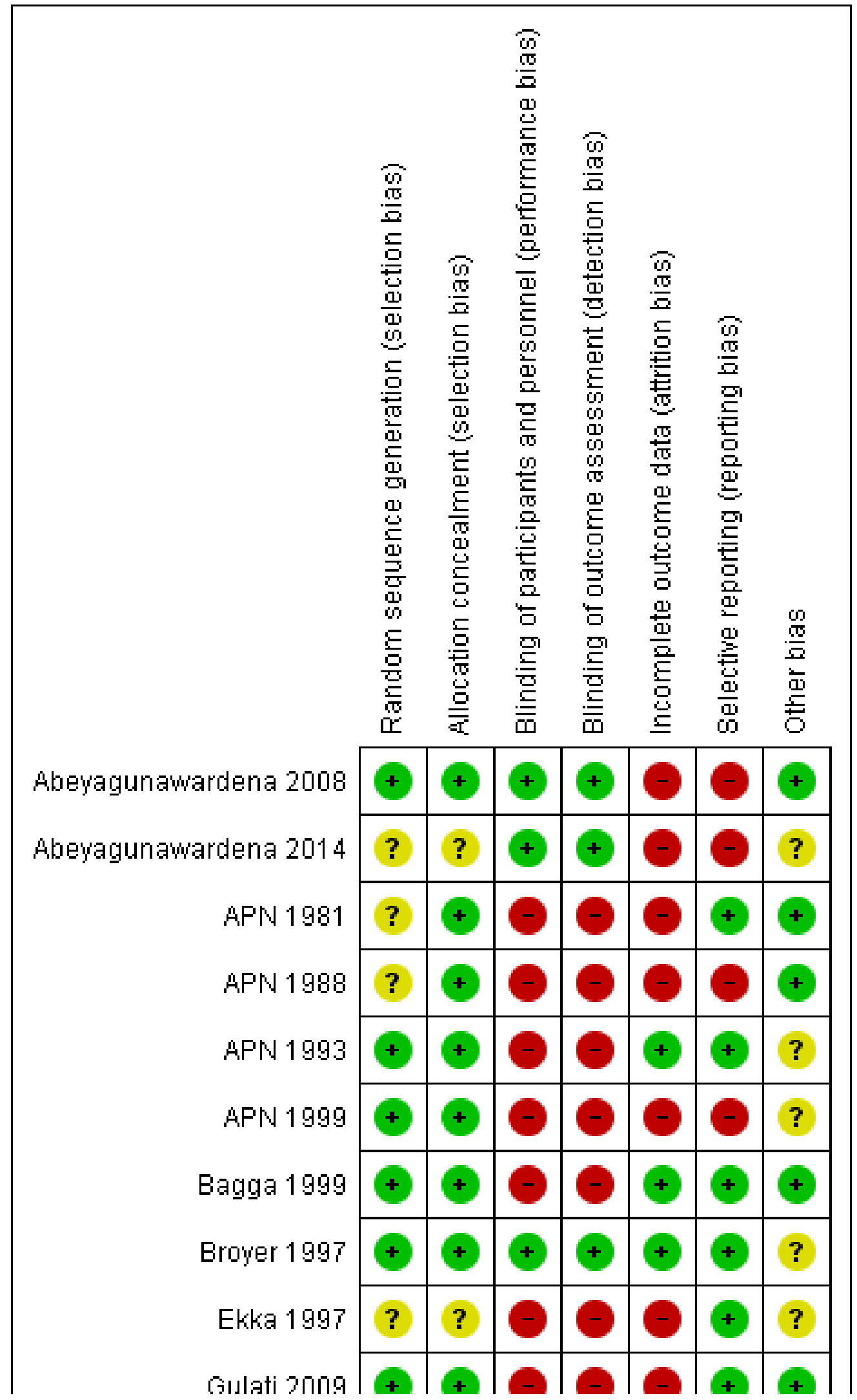


Figure 3. (Continued)

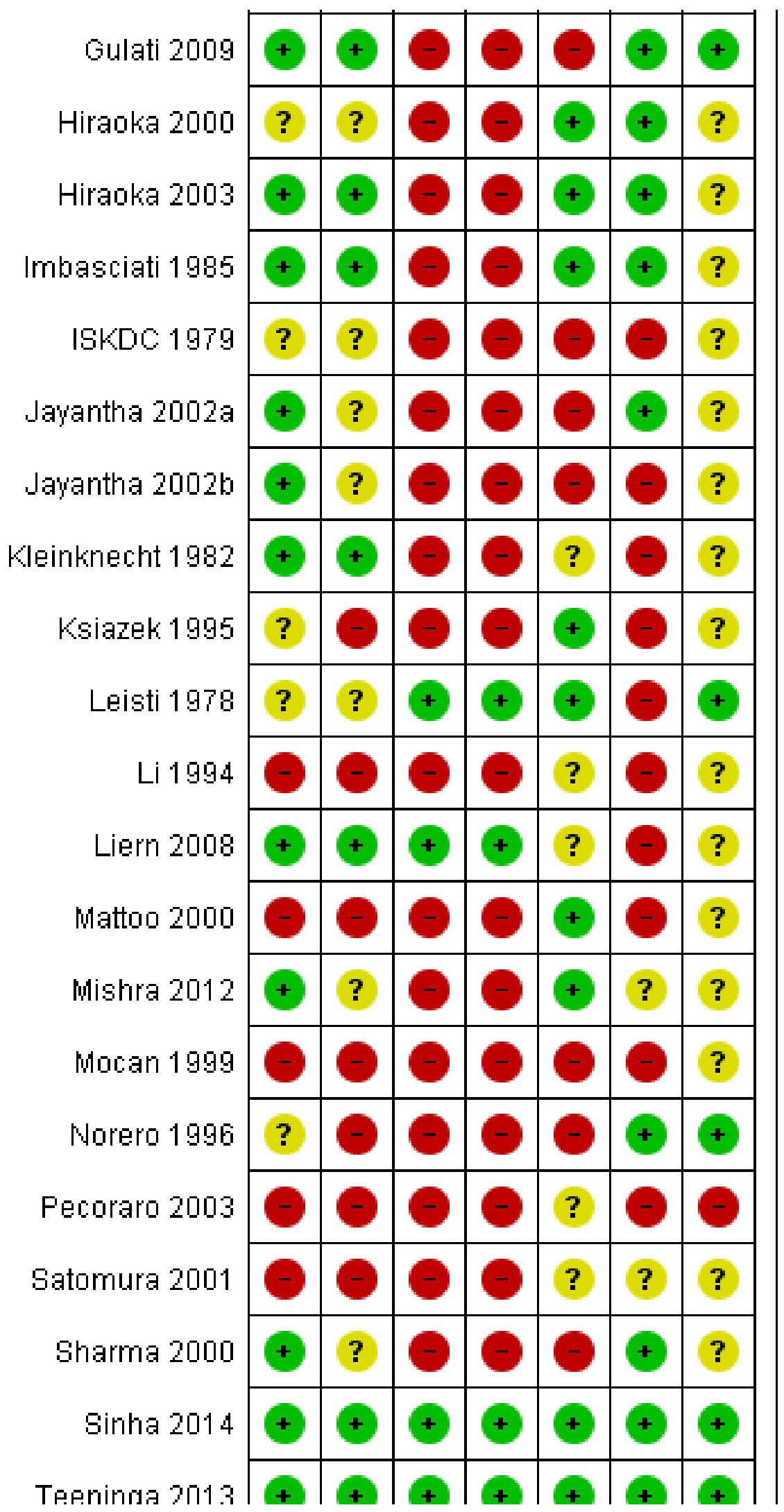


Figure 3. (Continued)

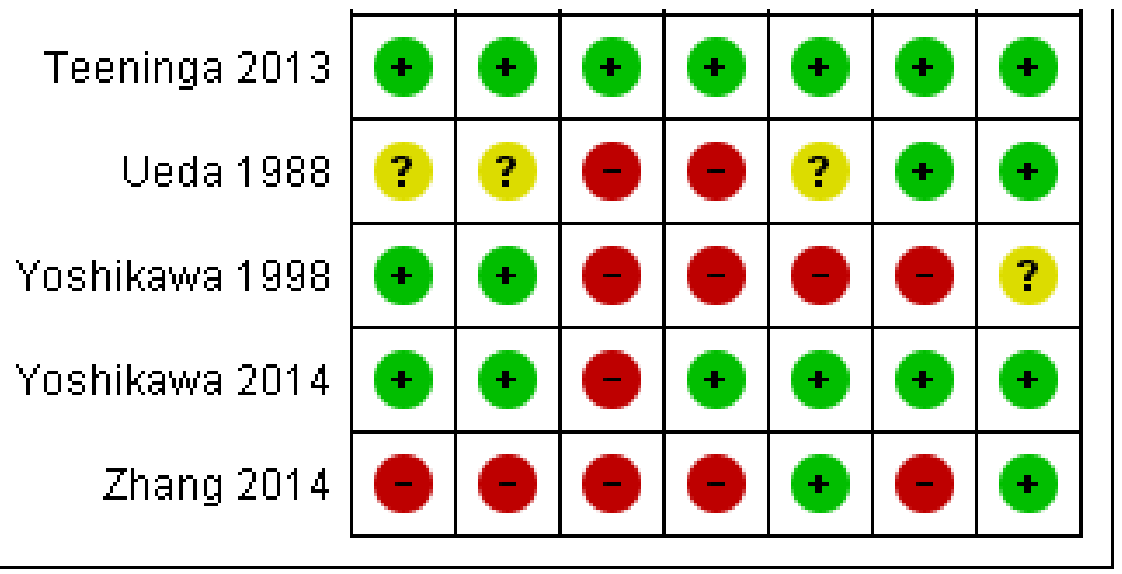

\section{Allocation}

Sequence generation was considered to be at low risk of bias in 18 studies (Abeyagunawardena 2008; APN 1993; APN 1999; Bagga 1999; Broyer 1997; Gulati 2009; Hiraoka 2003; Imbasciati 1985; Jayantha 2002a; Jayantha 2002b; Kleinknecht 1982; Liern 2008; Mishra 2012; Sharma 2000; Sinha 2014; Teeninga 2013; Yoshikawa 1998; Yoshikawa 2014), and high risk in six studies (Li 1994; Mattoo 2000; Mocan 1999, Pecoraro 2003; Satomura 2001; Zhang 2014). Sequence generation methods was assessed as unclear in the remaining 10 studies.

Allocation concealment was considered to be at low risk of bias in 16 studies (Abeyagunawardena 2008; APN 1981; APN 1988; APN 1993; APN 1999; Broyer 1997; Gulati 2009; Hiraoka 2003; Imbasciati 1985; Kleinknecht 1982; Liern 2008; Sinha 2014; Teeninga 2013; Yoshikawa 1998; Yoshikawa 2014) and at high risk of bias in eight studies (Ksiazek 1995; Li 1994; Mattoo 2000; Mocan 1999; Norero 1996; Pecoraro 2003; Satomura 2001; Zhang 2014). Ksiazek 1995 stated that parents could influence which treatment group their child was assigned. Allocation concealment methods was assessed as unclear in the remaining 10 studies.

\section{Blinding}

Seven studies were considered to be at low risk of performance and detection bias because they were placebo controlled studies (Abeyagunawardena 2008; Abeyagunawardena 2014; Broyer 1997; Leisti 1978; Liern 2008; Sinha 2014; Teeninga 2013). Yoshikawa 2014 was an open-label study but at low risk of detection bias. The remainder were at high risk of both performance and detection bias. Most studies reported the primary outcome of relapse using the ISKDC definition of relapse (ISKDC 1970).

\section{Incomplete outcome data}

We assessed 14 studies to be at low risk of attrition bias because they reported fewer than $10 \%$ of participants lost to followup or excluded from analysis (APN 1993; Bagga 1999; Broyer 1997; Hiraoka 2000; Hiraoka 2003; Imbasciati 1985; Ksiazek 1995; Leisti 1978; Mattoo 2000; Mishra 2012; Sinha 2014; Teeninga 2013; Yoshikawa 2014; Zhang 2014). Fourteen studies considered at high risk of attrition bias because more than $10 \%$ of participants were lost to follow-up or excluded from the analysis (Abeyagunawardena 2008; Abeyagunawardena 2014; APN 1981; APN 1988; APN 1999; Ekka 1997; Gulati 2009; ISKDC 1979; Jayantha 2002a; Jayantha 2002b; Mocan 1999; Norero 1996; Sharma 2000; Yoshikawa 1998). The remaining six studies were considered to be unclear risk of attrition bias.

\section{Selective reporting}

Studies were deemed to be at risk of reporting bias if outcome data did not include one or more outcomes of frequently relapsing nephrotic syndrome, relapse rate and adverse events. Studies were also considered to be at high risk of bias if data were provided in a format, which could not be entered into the meta-analyses. Cross-over studies were considered to be at high risk of bias if data from the first and second parts of the study were not separable. Sixteen studies were at low risk of reporting bias (APN 1981; APN 1993; Bagga 1999; Broyer 1997; Ekka 1997; Gulati 2009; Hiraoka 2000; Hiraoka 2003; Imbasciati 1985; Jayantha 2002a; Norero 1996; Sharma 2000; Sinha 2014; Teeninga 2013; Ueda 1988; Yoshikawa 2014). There were 16 studies at high risk of selective reporting bias (Abeyagunawardena 2008; Abeyagunawardena 2014; APN 1988; APN 1999; ISKDC 1979; Jayantha 2002b; Kleinknecht 1982; Ksiazek 1995; Leisti 1978; Li 1994; Liern 2008; Mattoo 2000; Mocan 1999; Pecoraro 2003; Yoshikawa 1998; Zhang 2014). Mishra 2012 and Satomura 2001 were assessed to be at unclear risk of selective reporting bias

\section{Other potential sources of bias}

Twelve studies were considered at low risk of potential bias as they were funded educational or philanthropic organisations (Abeyagunawardena 2008; APN 1981; APN 1988; Bagga 1999; Gulati 2009; Leisti 1978; Norero 1996; Sinha 2014; Teeninga 2013; Ueda 1988; Yoshikawa 2014; Zhang 2014). One study was considered to be at high risk of bias as it was funded by industry and no full-text publication has been identified 10 years after the first conference abstract (Pecoraro 2003). The remaining 21 studies were deemed unclear of other risk of bias as no information on funding sources was provided.

In Ueda 1988 the calculated total protocol dose $\left(4620 \mathrm{mg} / \mathrm{m}^{2}\right)$ exceeded the dose administered (3132 $\left.\pm 417 \mathrm{mg} / \mathrm{m}^{2}\right)$ suggesting that the protocol was not adhered to in all patients. In three studies (Jayantha 2002a; Ksiazek 1995; Ueda 1988) the numbers of children in the treatment and control groups differed markedly. 


\section{Effects of interventions}

See: Summary of findings for the main comparison Steroid therapy in first episode of nephrotic syndrome: three months of more versus two months for nephrotic syndrome in children; Summary of findings 2 Steroid therapy in first episode of nephrotic syndrome: five or six months versus three months for nephrotic syndrome in children

\section{Outcome of children in their first episode of SSNS}

\section{Three months or more versus two months therapy}

The risk of frequently relapsing nephrotic syndrome (FRNS) was significantly lower with prolonged duration of prednisone compared with two months (Analysis 1.1 (6 studies, 582 children): RR $0.68,95 \% \mathrm{Cl} 0.47$ to $1.00 ; 1^{2}=36 \%$ ).

The number of children relapsing by 12 to 24 months and the mean relapse rate/patient/year were significantly lower with prolonged duration of prednisone compared with two months (Analysis 1.2 (8 studies, 741 children): RR $0.80,95 \% \mathrm{Cl} 0.64$ to $1.00 ; \mathrm{I}^{2}=66 \%$ ); Analysis 1.3 ( 4 studies, 295 children): MD $-0.65,95 \% \mathrm{Cl}-1.29$ to -0.00 ; $\left.\mathrm{I}^{2}=88 \%\right)$. Cumulative prednisone dose did not differ significantly between groups (Analysis 1.4 (3 studies, 245 children): MD $0.71 \mathrm{~g} /$ $\mathrm{m}^{2}, 95 \% \mathrm{Cl}-0.67$ to $2.09 ; \mathrm{I}^{2}=60 \%$ ).

There was medium to high levels of heterogeneity between studies in all analyses.

The heterogeneity was not explained by inclusion/exclusion of patients with steroid-dependent disease, different durations of prednisone (three months versus more than three months) or different definitions of FRNS (ISKDC definition compared with other definitions) (Analysis 1.5).

Subgroup analysis based on risk of bias components (allocation concealment, attrition bias) indicated that there was no significant difference in the risk of FRNS in studies at low risk of bias for allocation concealment (Analysis 1.6.1 (3 studies, 362 children): RR $0.92,95 \% \mathrm{Cl} 0.69$ to $\left.1.23 ; \mathrm{I}^{2}=0 \%\right)$. In contrast the risk of FRNS was significantly increased in studies at high or unclear risk of bias for allocation concealment (Analysis 1.6.2 (3 studies, 220 children): RR $0.45,95 \% \mathrm{Cl} 0.26$ to $\left.0.77 ; 1^{2}=0 \%\right)$. The data for attrition bias are identical and are not shown. Thus heterogeneity between studies was explained by differences in risk of bias between studies.

Serious adverse events (growth retardation, hypertension, cataracts/glaucoma, psychological disorders, osteoporosis, infections, features of Cushing's Syndrome) were not significantly different between regimens (Analysis 1.7). In Yoshikawa 2014, results were reported as events not patients and are not included in the meta-analyses. The authors reported that frequency and severity of adverse events were similar in both groups.

\section{Five or six months versus three months therapy}

There was no significant difference in the risk of FRNS between prednisone treatment for five or six months compared with three months (Analysis 2.1 ( 5 studies, 591 children): RR $0.78,95 \% \mathrm{Cl} 0.50$ to $\left.1.22 ; 1^{2}=67 \%\right)$.

Prednisone given for five to six months significantly reduced the risk of relapse by 12 to 24 months compared with three months (Analysis 2.2 ( 7 studies, 763 children): RR $0.62,95 \% \mathrm{Cl} 0.45$ to 0.85 ; $\left.1^{2}=83 \%\right)$ and the mean relapse rate/patient/year was significantly reduced (Analysis 2.3 (3 studies, 460 children): MD $-0.39,95 \% \mathrm{Cl}$ -0.64 to $\left.-0.14 ; 1^{2}=40 \%\right)$. Cumulative prednisone dose did not differ significantly between groups (Analysis 2.4 ( 3 studies, 460 children): MD $-0.47,95 \% \mathrm{Cl}-1.67$ to $0.73 ; \mathrm{I}^{2}=85 \%$ ).

There was medium to high levels of heterogeneity among studies in all analyses.

The heterogeneity was not explained by inclusion/exclusion of patients with steroid dependent disease or different definitions of FRNS (ISKDC definition compared with other definitions) (Analysis 2.5).

Subgroup analysis of the risk for FRNS was performed based on risk of bias for allocation concealment, blinding (performance/ detection bias) and attrition. There was no significant difference in the risk of FRNS in studies at low risk of bias for allocation concealment (Analysis 2.6.1 (3 studies, 377 children): RR 1.00, $95 \% \mathrm{Cl} 0.74$ to $\left.1.34 ; \mathrm{I}^{2}=35 \%\right)$. In contrast the risk of FRNS was significantly increased in studies at high or unclear risk of bias for allocation concealment (Analysis 2.6.2 (2 studies, 14 children): RR $0.36,95 \% \mathrm{Cl} 0.18$ to $\left.0.72 ; 1^{2}=0 \%\right)$. Similarly there was no significant difference in the risk of FRNS in studies at low risk of performance/ detection bias or attrition bias (Analysis 2.7.1; Analysis 2.8.1) while there was a significant reduction in the risk of FRNS in studies at unclear or high risk of performance/detection bias or attrition bias (Analysis 2.7.2; Analysis 2.8.2). Thus heterogeneity between studies was explained by differences in risk of bias among studies.

Adverse effects did not differ significantly between groups (Analysis 2.9).

\section{One month versus two months therapy}

APN 1988 showed that prednisone duration less than the two month regimen resulted in a significantly higher relapse rate at six and 12 months (Analysis 3.1 ( 1 study, 61 children): RR 1.60, 95\% Cl 1.01 to 2.54; Analysis 3.2 (1 study, 60 children): RR 1.46, 95\% Cl 1.01 to 2.12). There was no significant differences in the risk for FRNS (Analysis 3.3) and the cumulative prednisone dose (Analysis 3.4).

\section{Five months versus 12 months therapy}

Kleinknecht 1982 showed no evidence that the relapse rate was significantly reduced by giving prednisone for one year compared with five months (Analysis 4.1).

\section{Different total doses of prednisone}

Hiraoka 2000 used different total prednisone doses in each group with both groups receiving treatment for three months. The number of children relapsing by 12 months was significantly reduced in children treated with the higher dose (Analysis 5.1 (1 study, 59 children): $\mathrm{RR} 0.63,95 \% \mathrm{Cl} 0.42$ to 0.94 ). However there was no significant difference in the risk for FRNS (Analysis 5.2 (1 study, 60 children): RR $0.69,95 \% \mathrm{Cl} 0.35$ to 1.37 ). Adverse effects did not differ between groups (Analysis 5.3).

\section{Two month steroid therapy and Sairei-to compared with 4.5 months prednisone and Sairei-to}

Yoshikawa 1998 showed no significant difference in relapse rate at two years or in the number of children who relapsed frequently between two months and four and a half months of prednisone 
when both groups received the Chinese herb, Sairei-to (Analysis 6.1).

\section{Three month steroid therapy and cyclosporin compared with 3 months prednisone}

APN 1999 showed that the addition of cyclosporin to 12 weeks of prednisone therapy reduced the risk for relapse at six months (Analysis 7.1 ( 1 study, 104 children): RR $0.33,95 \% \mathrm{Cl} 0.33$ to 0.83 ) and at 12 months (Analysis 7.2 ( 1 study, 104 children): RR 0.72, $95 \% \mathrm{Cl} 0.46$ to 1.13 ). The numbers needing cytotoxic therapy were not significantly different between groups (Analysis 7.3 (1 study, 104 children): RR $0.47,95 \% \mathrm{Cl} 0.18$ to 1.23 ). The median time of cumulative sustained remission after completing initial therapy was 22.8 months $(95 \% \mathrm{Cl} 11.6$ to 34$)$ in the cyclosporin/prednisone group and 12.5 months $(95 \% \mathrm{Cl} 5.9$ to 19.1$)$ in the prednisone only group. There was a delay in the time to relapse at six and 12 months but there were no differences at 18 and 24 months. The mean relapse rates/patient at six and 12 months of 0.12 and 0.63 in the cyclosporin/prednisone group were significantly lower than those in the prednisone-only group (0.57 and 1.03) but there was no difference at 18 and 24 months after therapy. Serum creatinine did not differ at the end of follow-up (Analysis 7.4). Temporary hirsutism and gum hypertrophy were seen in $60 \%$ and $9 \%$ of children given cyclosporin. Psychological disturbances occurred in $27 \%$ of cyclosporin-treated patients compared with $14 \%$ of patients treated with prednisone alone. Mean systolic and diastolic blood pressures were increased by $10 \mathrm{mmHg}$ and $8 \mathrm{mmHg}$ respectively during cyclosporin therapy.

\section{High dose oral methylprednisolone}

Mocan 1999 showed no significant difference in the time to relapse and the relapse rate at one year in patients receiving high dose oral methylprednisolone given over two weeks versus six months of prednisone therapy (Analysis 8.1 ( 1 study, 15 children): MD -8.10, $95 \% \mathrm{Cl}-30.51$ to 14.31 ); Analysis 8.2 (1 study, 15 children): MD 0.00, $95 \% \mathrm{Cl}-0.27$ to 0.27 ). However the mean time to remission was significantly shorter in the methylprednisolone group (Analysis 8.3 (1 study, 15 children): MD $-7.70,95 \% \mathrm{Cl}-13.24$ to -2.16 ).

\section{Azithromycin and prednisone versus prednisone alone}

Zhang 2014 found no significant difference in the risk of relapse by six months between prednisone with azithromycin and prednisone alone (Analysis 9.1).

\section{Outcome of children with frequently relapsing SSNS}

\section{Daily prednisone treatment during viral infections}

Abeyagunawardena 2008 demonstrated in a cross-over study that daily prednisone administered during an infection significantly reduced the risk of relapse compared with continuing alternate-day prednisone (Analysis 10.1 ( 1 study, 40 children): RR 0.49, 95\% CI 0.18 to 1.30 ; first part of study).

Gulati 2009 reported a significant reduction in infection related relapses per patient year (Analysis 10.2.1 (1 study, 95 children): MD $-0.70,95 \% \mathrm{Cl}-0.87$ to -0.53$)$ and in the total number of relapses/ patient-year (Analysis 10.2.2 (1 study, 95 children): MD -0.90, 95\% $\mathrm{Cl}-1.08$ to -0.72 ) in children receiving daily prednisone during infections compared with alternate daily prednisone.
Mattoo 2000 showed a significant reduction in the total relapse episodes/patient at two years (Analysis 10.3 (1 study, 36 participants): $\mathrm{MD}-3.30,95 \% \mathrm{Cl}-4.03$ to -2.57 ) in children receiving daily prednisone during infections compared with alternate-day prednisone.

Abeyagunawardena 2014 found in a cross-over study that children with SSNS off prednisone for at least three months had fewer relapses when administered prednisone for five days at the onset of upper respiratory tract infection (URTI) compared with placebo (11 relapses in 113 URTI versus 25 relapses in 101 URTI; $P=$ 0.014). $65.5 \%$ of children in the prednisone group had no relapses compared with $40.6 \%$ in the placebo group.

\section{Other comparisons of prednisone usage}

Nine studies included children with relapsing SSNS (APN 1981; Broyer 1997; Ekka 1997; Imbasciati 1985; ISKDC 1979; Jayantha 2002b; Leisti 1978; Li 1994; Liern 2008) (Table 1).

Alternate-day therapy (APN 1981) was more effective than intermittent therapy in maintaining remission in frequently relapsing children during six months of therapy (Analysis 11.1.1: RR $0.60,95 \% \mathrm{Cl} 0.36$ to 1.02 ) but there was no difference by 12 months (Analysis 11.2.1: RR 1.20, 95\% Cl 0.93 to 1.55 ).

Single daily dosing (Ekka 1997) was as effective as multiple daily dosing in maintaining remission in children who relapsed frequently (Analysis 11.2.1: RR $1.07,95 \% \mathrm{Cl} 0.77$ to 1.50 ) with no significant difference in the mean relapse rate/patient (Analysis 11.3.1 (94 children): MD $-0.20,95 \% \mathrm{Cl}-0.64$ to 0.24 ). The time to remission did not differ between single and multiple daily dosing patient groups (Analysis 11.6 (2 studies, 138 children): MD 0.04 days, $95 \% \mathrm{Cl}-0.98$ to $1.06 ; \mathrm{I}^{2}=0 \%$ ). Serious side effects including hypertension were less common in the single daily dose patients compared with divided dose patients (Analysis 11.7 (2 studies, 138 children): RR $0.41 ; 95 \% \mathrm{Cl} 0.18$ to $\left.0.91 ; \mathrm{I}^{2}=0 \%\right)$. In one study, cushingoid features and obesity were less common in the single daily dose group (Li 1994).

Deflazacort (Broyer 1997) significantly reduced the number of children who relapsed during therapy (Analysis 11.2.4 (40 children): RR $0.44,95 \% \mathrm{Cl} 0.25$ to 0.78 ) and reduced the relapse rate among those who relapsed (Analysis 11.3.3 (40 children): MD -1.90, 95\% Cl -2.77 to -1.03$)$ without significant differences in side effects.

The mean time to relapse in a cross-over study (Liern 2008), comparing alternate-day methylprednisolone with an equivalent dose of deflazacort after the first relapse, was longer in deflazacort treated patients ( $105 \pm 4.19$ days) compared with those treated with methylprednisolone ( $85 \pm 3.8$ days). There was no differences in the mean time to remission.

Children (ISKDC 1979) relapsed significantly less frequently during treatment on daily prednisone compared with intermittent therapy (Analysis 11.1.2 (50 children): RR $0.20,95 \% \mathrm{Cl} 0.05$ to 0.82 ) but the numbers with relapse (Analysis 11.2.5 (50 children): RR 1.00, 95\% $\mathrm{Cl} 0.89$ to 1.12) and the mean relapse rate/patient did not differ by nine months after treatment (Analysis 11.3.2 (50 children): MD 0.54, $95 \% \mathrm{Cl}-0.50$ to 1.58$)$. During treatment the mean time to relapse was significantly longer in children treated with daily prednisone (Analysis 11.4.2 (50 children): MD 1.79, 95\% Cl 0.90 to 2.68). 
Remission rate at one year was not significantly different between children who received intravenous methylprednisolone during induction and those who received oral prednisone only (Imbasciati 1985) (Analysis 11.2 .3 ( 64 children): RR $1.06,95 \% \mathrm{Cl} 0.75$ to 1.53 ) but the total dose of oral prednisone administered was higher in the control group than in the group receiving intravenous prednisone.

A cross-over study (Leisti 1978) showed that fewer children with post-prednisone adrenocortical suppression relapsed during a six month period if they received partial cortisol substitution with 5 $\mathrm{mg}$ of cortisol during remission in comparison with placebo. The data for the patients were combined for each treatment period so the data for the first comparison could not be displayed in a meta-analysis. After three months treatment, 5/13 children (38\%) receiving cortisol had relapsed compared with $12 / 13$ receiving placebo $(92 \%)\left(\mathrm{Chi}^{2}=4.0, \mathrm{P}=0.05\right)$, and at six months $9 / 13$ children receiving cortisol had relapsed compared with $12 / 13$ receiving placebo.

Significantly fewer children treated with prednisone for seven months relapsed by six months (Analysis 12.1.1 (90 children): RR $0.04,95 \% \mathrm{Cl} 0.01$ to 0.25 ), 12 months (Analysis $12.1,2$ (76 children): RR $0.4395 \% \mathrm{Cl} 0.29$ to 0.65 ), two years (Analysis 12.1 .3 ( 64 children): RR $0.60,95 \% \mathrm{Cl} 0.45$ to 0.80 ) and three years (Analysis 12.1.4 (53 children) RR $0.71,95 \% \mathrm{Cl} 0.56$ to 0.90 ) compared with standard duration therapy (Jayantha 2002b). The relapse rate/patient/year excluding patients who became steroid dependent was reduced at one (Analysis 12.2.1 (72 children): MD-1.78, 95\% Cl -2.30 to -1.26), two (Analysis 12.2.2 (56 children): MD -1.79, 95\% Cl -2.39 to -1.19 ) and three years (Analysis 12.2 .3 (41 children): MD-1.74, $95 \% \mathrm{Cl}-2.39$ to -1.09 ) after treatment and the number of children who developed steroid dependence or relapsed frequently by one year was reduced (Analysis 12.3 (72 children): RR $0.43,95 \% \mathrm{Cl}$ 0.19 to 0.95 ) in the long duration group compared with standard duration. Cumulative steroid dose excluding patients who became steroid dependent during the study was higher at one year (Analysis 12.4.1 (72 children): $M D 0.59 \mathrm{~g} / \mathrm{kg}, 95 \% \mathrm{Cl} 0.02$ to 1.16 ) in the long treatment group but did not differ at two (Analysis 12.4.2 ( 56 children): $\mathrm{MD}-0.32 \mathrm{~g} / \mathrm{kg}, 95 \% \mathrm{Cl}-1.52$ to 0.88 ) and three years (Analysis 12.4.3: MD -1.13 g//kg, 95\% Cl-3.08 to -0.82). Hypertension was more common in the long duration group but the difference was not statistically significant (Analysis 12.5 .1 (72 children): RR $2.40,95 \% \mathrm{Cl} 0.86$ to 6.73 ); the number of children with growth failure did not differ between groups (Analysis 12.5 .2 (72 children): RR $1.24,95 \% \mathrm{Cl} 0.62$ to 2.50 ).

\section{DISCUSSION}

\section{Summary of main results}

We added 10 studies to this 2015 update to bring the total number of included studies to 34 enrolling 3033 children. Analysis of data from three studies has led to the new conclusion that in studies at low risk of bias, there is no significant difference in the risk for FRNS between two and three months of prednisone and more than three months of prednisone in the initial episode of SSNS. Data from three other studies increased the evidence base to support administering prednisone or increasing the dose during URTI to reduce the risk of relapse in children with FRNS.

\section{Prednisone in the first episode of SSNS}

Our initial review in 2000 demonstrated that prednisone administered for three months or more significantly reduced the risk of relapse by 12 to 24 months and of FRNS compared with two months in the initial episode of SSNS. Increasing the duration of prednisone up to seven months increased the benefit obtained. It was unclear whether the increase in benefit was related to increased duration or increased dose though indirect analyses suggested that duration was more important than dose. However it was also noted that some included studies in the analyses were at unclear or high risk of bias. In the 2003 and 2005 updates, additional studies were identified which reported that six months of prednisone significantly reduced the risk of relapse compared with three months. In clinical practice, paediatric nephrologists tended to use increasing durations of prednisone in the initial episode of nephrotic syndrome though considerable variation existed between physicians reflecting in part the poor quality of the evidence from randomised studies (MacHardy 2009; Samuel 2013).

This 2015 update included three large, well designed studies (Sinha 2014; Teeninga 2013; Yoshikawa 2014) comparing different durations of prednisone. In Teeninga 2013 children received the same total dose of prednisone administered over three or six months, however children included in Sinha 2014 and Yoshikawa 2014 received a higher total dose of prednisone in the six months treatment group compared with the shorter treatment group. Inclusion of these studies in meta-analyses showed that the risk of relapse by 12 to 24 months and of FRNS continued to favour extended duration of prednisone except for the analysis of FRNS in the comparison of five to six months with three months of prednisone. However there was considerable heterogeneity between studies with $\mathrm{I}^{2}$ results varying between $36 \%$ and $83 \%$. Subgroup analysis stratified for the risk of bias domains showed that studies at low risk of bias for allocation concealment, attrition bias and performance/detection bias found no significant differences in the risk of relapse by 12 to 24 months or FRNS between two to three months of prednisone and three to seven months. Studies at high risk of bias on the other hand showed significant benefits of increasing treatment duration. Therefore studies of long versus shorter duration corticosteroids have heterogeneous treatment effects, with the older high risk of bias studies tending to over-estimate the effect of longer course therapy, compared with more recently published low risk of bias studies. Among studies at low risk of bias, there was no significant difference in the risk for FRNS between prednisone given for two to three months and longer durations or total dose of therapy indicating that there is no benefit of increasing the duration of prednisone beyond two to three months in the initial episode of SSNS. A study comparing two months with four months of prednisone is currently underway in Europe (PREDNOS Study 2013).

\section{Prednisone in relapsing SSNS}

Daily prednisone during viral infections compared with alternateday prednisone therapy reduced the rate of relapse. Three additional larger studies of improved methodological quality have increased the power of this analysis so that this management may be considered for children with frequently relapsing SSNS, who are already receiving alternate-day prednisone. Preliminary data from a fourth study suggests that daily prednisone during URTI reduces the risk of relapse in children not receiving prednisone. A further 
study addressing this question is currently underway in Europe (PREDNOS 2 Study 2014).

\section{Overall completeness and applicability of evidence}

This review includes studies evaluating corticosteroid therapy and nephrotic syndrome, with the majority of studies focusing on therapy for the initial presentation of nephrotic syndrome. Three additional well designed studies involving 562 children has led to the change in conclusions for this review so that the optimum duration of prednisone is suggested to be two or three months of prednisone in the initial episode of SSNS rather than longer durations as argued in previous versions of this review.

There remain few data on the treatment of relapsing nephrotic syndrome with prednisone. In particular there are no studies addressing the use of long term alternate-day corticosteroid therapy to maintain remission in children with frequently relapsing nephrotic syndrome although this management is widely recommended in guidelines (KDIGO 2012).

Adverse effects of medications were either not reported or there was limited reporting in studies. Among 16 studies evaluating increased duration or dose in the initial episode of SSNS, hypertension, ophthalmological disorders and Cushing's syndrome were reported in 12, 11 and eight studies respectively. Prednisone therapy is known to be associated with significant behavioural and psychological adverse effects (Mishra 2010; Neuhaus 2010). However only seven of these studies reported this outcome and no studies reported data on quality of life for the child or their family. Adverse effects of medications were reported in more detail in the three well designed studies published in 2013 and 2014 (Sinha 2014; Teeninga 2013; Yoshikawa 2014).

The studies included the major ethnic groups, but there are few separable data for African-American or African children. These groups of children, who are known to have a higher incidence of initial and late steroid-resistant nephrotic syndrome (Kim 2005; Gipson 2011), may show different responses in studies of increased dose or duration of prednisone.

\section{Quality of the evidence}

Of the 34 studies included, only $18(53 \%)$ and 16 studies (47\%) revealed adequate random sequence generation and allocation concealment respectively. In part this may be due to suboptimal reporting of these parameters in earlier studies. However some studies published recently failed to provide adequate information on these parameters. Blinding of participants, investigators and outcome assessors was only reported in seven $(21 \%)$ studies. Studies without blinding were considered at high risk of bias because knowledge of treatment groups could influence both patient management and reporting of remission and relapse by urinalyses. Both attrition bias (incomplete reporting of outcome data) and reporting bias (selective outcome reporting) were at low risk of bias in fewer than $50 \%$ of studies. Studies with inadequate allocation concealment can exaggerate the efficacy of the experimental treatment by $30 \%$ to $40 \%$ (Schulz 1995) and metaanalyses of low quality studies may overestimate the benefit of therapy (Moher 1998). Addition of recently published well designed studies resulted in significant heterogeneity in the primary efficacy outcomes (relapse, FRNS) in studies assessing the duration of prednisone for the initial episode of SSNS. Subgroup analyses of these studies demonstrated that older studies at higher risk of bias overestimated the benefit of increased duration of prednisone while newer studies at low risk of bias found no significant benefit of prolonging prednisone beyond two to three months in the initial episode of nephrotic syndrome resulting in changed conclusions for this review.

In summary of finding tables (Summary of findings for the main comparison; Summary of findings 2) for comparisons of two months with three months or more, and of three months with five or six months in the first episode of SSNS, the overall quality of studies was considered low for efficacy outcomes because of a high risk of bias in some studies and heterogeneity between studies. When studies with the outcome of FRNS were separated into subgroups according to risk of bias for allocation concealment, the quality of the evidence was considered high for studies at low risk of allocation concealment and moderate for studies at high or uncertain risk of bias of allocation concealment. The quality of studies for the adverse effects was considered moderate or low because of inclusion of some poor quality studies and few included studies.

Only 15/34 studies were included in the summary of findings tables and all compared treatment regimens in the first episode of nephrotic syndrome. The remaining studies were single studies or data could not be included in the meta-analyses.

\section{Potential biases in the review process}

A detailed search using the Cochrane Renal Group's Specialised Register was completed in February 2015. The Renal Register contains conference abstracts as well as published studies and there is no language restriction. This minimised the risk that eligible studies were omitted, although more recently published eligible studies and eligible studies in some congress proceedings not searched could have been missed. There were $10(29 \%)$ included studies that were only available in abstract form with limited information on study methods and outcomes. Failure to include these studies could result in overestimation of treatment effect since it is known that negative studies are less likely to be published or may be published later than positive studies (Hopewell 2007). Alternately, some authors have argued that inclusion of these studies could result in overestimation of treatment effect through selective outcome reporting and incomplete reporting of the number of patients completing follow-up (Egger 2001).

Many studies were small and had incomplete information on study methods and results and further results particularly of older studies could not be obtained despite contacting authors. Of the 34 included studies 19 were published in 2000 or earlier - before the CONSORT checklist first published in 1996 would be likely to influence study methodology and reporting (Moher 2001).

This was an extensive review; each step was completed independently by at least two authors thus minimising risks of errors in determining study eligibility, data extraction and risk of bias assessment and data synthesis.

\section{Agreements and disagreements with other studies or reviews}

New studies at low risk of bias included in this review indicate that there is no significant benefit of treating children for more than two to three months in the initial episode of SSNS. The KDIGO 2012 
and other country based guidelines (Gipson 2009; Haute Autorite de Santé 2008; IPNG-IAP 2008) recommend treatment with three months or more of prednisone for the initial episode of SSNS.

In support of the KDIGO guidelines (KDIGO 2012), this review identified four studies showing that increasing prednisone administration from alternate-day to daily or giving prednisone to children not on prednisone at the onset of an intercurrent viral infection reduces the risk of relapse.

This review did not identify any RCTs evaluating the use of prolonged courses of alternate-day prednisone to reduce the risk for relapse in children with frequently relapsing nephrotic syndrome although guidelines (Gipson 2009; Haute Autorité de Santé 2008; IPNG-IAP 2008; KDIGO 2012) have recommended this practice.

The listed guidelines and narrative reviews (Greenbaum 2012) emphasise the use of non-corticosteroid immunosuppressive medications in children with frequently relapsing or steroid dependent disease. These medications are the subject of another Cochrane systematic review (Pravitsitthikul 2013).

\section{AUTHORS' CONCLUSIONS}

\section{Implications for practice}

Prolongation of prednisolone therapy beyond two to three months in the initial episode of SSNS does not reduce the risk of relapse in studies at low risk of bias whether the same total dose of prednisone is used for short and long durations or whether the total dose of prednisone is increased with longer durations of treatment. The results of a further well designed study evaluating different durations and therefore total doses of prednisone are awaited (PREDNOS Study 2013).

Daily prednisone therapy during an upper respiratory infection or other infection reduces the risk of relapse compared with continuing alternate-day prednisone or no prednisone.

During daily therapy, prednisone is as effective when administered as a single daily dose compared with divided doses.

\section{Implications for research}

We now know that administering prednisone over six months rather than two or three months does not reduce the risk of relapse or of developing frequently relapsing disease. However all studies evaluating the duration of prednisolone have used similar daily and alternate daily doses of prednisolone based on the empirical regimens established by ISDKC and Arbeitsgemeinschaft für Pädiatrische Nephrologie in the 1970s and 1980s so we still do not know whether the same results could be obtained with lower total doses of prednisolone.

Adverse events including hypertension, ophthalmological disorders and behavioural or psychological effects are poorly reported. Recently published studies have provided additional information on adverse effects. The results of the PREDNOS Study 2013 comparing eight weeks with 16 weeks of prednisone will include a detailed assessment of the behavioural effects of prednisone.

Further RCTs are required to evaluate different durations of alternate-day prednisone regimens in children with frequently relapsing SSNS as prolonged alternate-day prednisone is recommended in current guidelines although there are no RCT data to support this recommendation.

Four RCTs from emerging countries have shown that daily prednisone administered during an intercurrent infection reduces the risk of relapse. A further well designed RCT is currently assessing this intervention in European children, where the pattern of intercurrent infections may be different (PREDNOS 2 Study 2014).

There is some evidence that children with SSNS suffer postprednisone adrenal insufficiency and that this state may predispose to relapse. The efficacy of cortisol substitution in such children should be examined in a further RCT.

Further studies of deflazacort in comparison with prednisone with larger numbers of patients and longer follow-up periods are required in children with frequently relapsing nephrotic syndrome to confirm its efficacy. Studies including the use of ACTH in comparison with prednisone may also be of benefit.

\section{ACKNOWLEDGEMENTS}

We are grateful to $\mathrm{Dr}$ John $\mathrm{F}$ Knight who contributed to the design, quality assessment, data collection, entry, analysis and interpretation, and writing of early versions of this review (Hodson 2000; Hodson 2005).

The authors would like to thank Professor A Bagga, Professor A Abeyagunawardena, Professor PF Hoyer, Professor UK Jayantha, Dr C Kleinknecht, Professor M Liern, Professor TE Mattoo, Professor O Mishra, Professor RK Sharma and Professor N Yoshikawa for the information that they provided about their studies. The authors wish to thank Professors Barratt, Brodehl, Broyer and Ponticelli for responding to our requests for information about unpublished studies.

We would like to thank the referees for their editorial advice during the preparation of this review and its updates. 


\section{R E F E R E N C E S}

\section{References to studies included in this review}

\section{Abeyagunawardena 2008 \{published data only\}}

Abeyagunawardena AS, Trompeter RS. Increasing the dose of prednisolone during viral infections reduces the risk of relapse in nephrotic syndrome: a randomised controlled trial. Archives of Disease in Childhood 2008;93(3):226-8. [MEDLINE: 17573408]

\section{Abeyagunawardena 2014 \{published and unpublished data\}}

Abeyagunawardena A, Thalgahagoda S, Illangasekera $\mathrm{Y}$, Trompeter R. A short course of prednisolone during an upper respiratory tract infection reduces the risk of relapse in childhood nephrotic syndrome [abstract]. Pediatric Nephrology 2014;29(9):1689. [EMBASE: 71662409]

Abeyagunawardena AS, Thalgahagoda S, Illangasekera Y, Trompeter RS. Short course of daily prednisolone during upper respiratory tract infection reduces the risk of relapse in childhood nephrotic syndrome [abstract]. Archives of Disease in Childhood 2014;99:A155-6. [EMBASE: 71566356]

\section{APN 1981 \{published data only\}}

${ }^{*}$ Anonymous. Alternate-day prednisone is more effective than intermittent prednisone in frequently relapsing nephrotic syndrome. A report of "Arbeitsgemeinschaft fur Padiatrische Nephrologie". European Journal of Pediatrics 1981;135(3):229-37. [MEDLINE: 7227377]

Anonymous. Alternate-day versus intermittent prednisone in frequently relapsing nephrotic syndrome. A report of "Arbetsgemeinschaft fur Padiatrische Nephrologie". Lancet 1979;1(8113):401-3. [MEDLINE: 84259]

Brodehl J, Krohn HP. Steroid trial in frequently relapsing nephrotic syndrome in children. Glomerulonephritis. International Conference on pathogenesis, pathology and treatment. New York: Wiley, 1977:210-5.

\section{APN 1988 \{published data only\}}

Anonymous. Short versus standard prednisone therapy for initial treatment of idiopathic nephrotic syndrome in children. Arbeitsgemeinschaft fur Padiatrische Nephrologie. Lancet 1988;1(8582):380-3. [MEDLINE: 2893190]

Brodehl J, Krohn HP, Ehrich JH. The treatment of minimal change nephrotic syndrome (lipoid nephrosis): cooperative studies of the Arbeitsgemeinschaft fur Padiatrische Nephrologie (APN). Klinische Padiatrie 1982;194(3):162-5. [MEDLINE: 6752557]

Ehrich JH. Initial treatment of idiopathic nephrotic syndrome: short vs standard prednisone [abstract]. 10th International Congress of Nephrology; 1987 Jul 26-31; London, UK. 1987:59. [CENTRAL: CN-00644361]

${ }^{*}$ Ehrich JH for the Arbeitsgemeinschaft fur Padiatrische Nephrologie (APN). Short initial prednisone therapy versus standard prednisone therapy in the steroid responsive nephrotic syndrome [abstract]. Pediatric Nephrology 1987;1(1):C28. [CENTRAL: CN-00445202]
APN 1993 \{published data only\}

Ehrich JH, Arbeitsgemeinschaft fur Padiatrische Nephrologie. Minimal change nephrotic syndrome: long prednisone therapy vs standard prednisone therapy [abstract]. Nephrology Dialysis Transplantation 1991;6(10):771. [CENTRAL: CN-00260613]

* Ehrich JH, Brodehl J. Long versus standard prednisone therapy for initial treatment of idiopathic nephrotic syndrome in children. Arbeitsgemeinschaft fur Padiatrische Nephrologie. European Journal of Pediatrics 1993;152(4):357-61. [MEDLINE: 8482290]

\section{APN 1999 \{published data only\}}

Arbeitsgemeinschaft fur Padiatrische Nephrologie. Results of the nephrotic syndrome study VIII of the APN: new standard treatment versus new standard treatment plus 8 weeks cyclosporin A [abstract]. Pediatric Nephrology 1999;13:C26. [CENTRAL: CN-00636143]

Hoyer PF. Results of the nephrotic syndrome study VIII of the APN: new standard treatment versus new standard treatment plus 8 weeks cyclosporin A [abstract]. Journal of the American Society of Nephrology 1999;10(Program \& Abstracts):104A. [CENTRAL: CN-00550522]

Hoyer PF for the Arbeitsgemeinschaft fur Padiatrische Nephrologie. The initial treatment of idiopathic nephrotic syndrome with prednisone and cyclosporin A: preliminary results of a therapeutic trial [abstract]. Pediatric Nephrology 1995;9(6):C91. [CENTRAL: CN-00401335]

* Hoyer PF, Brodehl J. Initial treatment of idiopathic nephrotic syndrome in children: prednisone versus prednisone plus cyclosporine A: a prospective, randomized trial. Journal of the American Society of Nephrology 2006;17(4):1151-7. [MEDLINE: 16540560]

\section{Bagga 1999 \{published and unpublished data\}}

Bagga A, Hari P, Srivastava RN. Long (LP) versus standard (SP) initial prednisolone treatment for idiopathic nephrotic syndrome (NS) [abstract no: P225]. Pediatric Nephrology 1998;12:C155. [CENTRAL: CN-00583944]

Bagga A, Hari P, Srivastava RN. Long (LP) versus standard (SP) initial prednisolone treatment for nephrotic syndrome (NS) [abstract]. 3rd Congress. Nephrology Urology Transplantation Society (NUTS) of SAARC; 1999 Feb 18 - 21; Colombo, Sri Lanka. 1999:158. [CENTRAL: CN-00460325]

* Bagga A, Hari P, Srivastava RN. Prolonged versus standard prednisolone therapy for initial episode of nephrotic syndrome. Pediatric Nephrology 1999;13(9):824-7. [MEDLINE: 10603129]

\section{Broyer 1997 \{published data only\}}

Broyer M, Terzi F, Gagnadoux MF, Guest G, Niaudet P. A randomized double blind study of deflazacort (D) versus prednisone $(P)$ in the treatment of idiopathic nephrotic syndrome (INS) [abstract]. Journal of the American Society of Nephrology 1995;6(3):414. [CENTRAL: CN-00483349] 
Broyer M, Terzi F, Lehnert A, Gagnadoux MF, Guest G, Niaudet P. A controlled study of deflazacort in the treatment of idiopathic nephrotic syndrome. Pediatric Nephrology 1997;11(4):418-22. [MEDLINE: 9260237]

\section{Ekka 1997 \{published data only\}}

Bagga A, Ekka BK, Srivastava RN. Single versus divided dose prednisolone therapy for relapses of nephrotic syndrome (NS) [abstract]. Nephrology Dialysis Transplantation 1997;12(9):A113. [CENTRAL: CN-00261391]

Ekka BK, Bagga A, Srivastava RN. Single- versus divided-dose prednisolone therapy for relapses of nephrotic syndrome. Pediatric Nephrology 1997;11(5):597-9. [MEDLINE: 9323286]

\section{Gulati 2009 \{published data only\}}

Gulati A, Math A, Sreeniwas V, Hari P, Bagga A. Administration of daily corticosteroids prevents infection associated relapses in frequently relapsing nephrotic syndrome [abstract no: SU714]. World Congress of Nephrology; 2009 May 22-26; Milan, Italy. 2009.

Gulati A, Sinha A, Sreenivas V, Math A, Hari P, Bagga A. Daily corticosteroids reduce infection-associated relapses in frequently relapsing nephrotic syndrome: a randomized controlled trial. Clinical Journal of The American Society of Nephrology: CJASN 2011;6(1):63-9. [MEDLINE: 20847092]

\section{Hiraoka 2000 \{published data only\}}

Hiraoka M, Sudo M, West Japanese Cooperative Study of Kidney Disease in Children. Low versus standard dosage of prednisolone for initial treatment of idiopathic nephrotic syndrome in children [abstract no: A0445]. Journal of the American Society of Nephrology 1996;7(9):1335.

* Hiraoka M, Tsukahara H, Haruki S, Hayashi S, Takeda N, Miyagawa $\mathrm{K}$, et al. Older boys benefit from higher initial prednisolone therapy for nephrotic syndrome. The West Japan Cooperative Study of Kidney Disease in Children. Kidney International 2000;58(3):1247-52. [MEDLINE: 10972687]

Hiraoka M, Tsukahara H, Haruki S, Hayashi S, Takeda N, Miyagawa $\mathrm{K}$, et al. Older boys benefit from intensive initial prednisolone therapy for nephrotic syndrome [abstract]. Journal of the American Society of Nephrology 1999;10(Program \& Abstracts):103A. [CENTRAL: CN-00550605]

\section{Hiraoka 2003 \{published data only\}}

* Hiraoka M, Tsukahara H, Matsubara K, Tsurusawa M, Takeda N, Haruki S, et al. A randomized study of two long-course prednisolone regimens for nephrotic syndrome in children. American Journal of Kidney Diseases 2003;41(6):1155-62. [MEDLINE: 12776266]

\section{Imbasciati 1985 \{published data only\}}

Imbasciati E, Gusmano R, Edefonti A, Zucchelli P, Pozzi C, Grassi C, et al. Controlled trial of methylprednisolone pulses and low dose oral prednisone for the minimal change nephrotic syndrome. British Medical Journal Clinical Research Ed 1985;291(6505):1305-8. [MEDLINE: 3933645]

\section{ISKDC 1979 \{published data only\}}

Anonymous. Nephrotic syndrome in children: a randomized trial comparing two prednisone regimens in steroid-responsive patients who relapse early. Report of the International Study of Kidney Disease in Children. Journal of Pediatrics 1979;95(2):239-43. [MEDLINE: 109598]

Jayantha 2002a \{published and unpublished data\}

Jayantha UK. Comparison of ISKDC regime with a 7 months steroid regime in the first attack of nephrotic syndrome [abstract]. Pediatric Nephrology 2004;19:C81. [CENTRAL: CN-00583710]

Jayantha UK. Comparison of ISKDC regime with a six month steroid regime in the treatment of steroid sensitive nephrotic syndrome. Unpublished results 2002.

* Jayantha UK. Comparison of ISKDC regime with a six month steroid regime in the treatment of steroid sensitive nephrotic syndrome [abstract no: FP2B]. 7th Asian Congress of Pediatric Nephrology; 2000 Nov 1-4; Singapore. 2000:28. [CENTRAL: CN-00583708]

\section{Jayantha 2002b \{published and unpublished data\}}

Jayantha UK. Comparison of ISKDC regime with 6 month regime in patients with relapsing nephrotic syndrome. Unpublished results 2002 .

* Jayantha UK. Prolong versus standard steroid therapy for children with relapsing course of nephrotic syndrome [abstract no: P026]. Pediatric Nephrology 2004;19(9):C99. [MEDLINE: CN-00583706]

Kleinknecht 1982 \{published and unpublished data\}

Kleinknecht C, Broyer M, Parchoux B, Loriat C, Nivet H, Palcoux JB, et al. Comparison of short and long treatment at onset of steroid sensitive nephrosis (SSN). Preliminary results of a multicenter controlled trial for the French Society of Pediatric Nephrology [abstract]. International Journal of Pediatric Nephrology 1982;3(1):45. [CENTRAL: CN-00550480]

Ksiazek 1995 \{published data only\}

Ksiazek J, Wyszynska T. Short versus long initial prednisone treatment in steroid-sensitive nephrotic syndrome in children. Acta Paediatrica 1995;84(8):889-93. [MEDLINE: 7488812]

\section{Leisti 1978 \{published data only\}}

* Leisti S, Koskimies O, Perheentupa J, Vilska J, Hallman N. Idiopathic nephrotic syndrome: prevention of early relapse. British Medical Journal 1978;1(6117):892. [MEDLINE: 346147]

\section{Li 1994 \{published data only\}}

Li X, Li Z, Cheng Z. Treatment of children with simple nephrotic syndrom using prednison once per day. Acta Academiae Medicinae Hubei 1994;15(4):386-8. [EMBASE: 1995005617]

\section{Liern 2008 \{published data only\}}

Liern M, Dieguez S, Canepa C. Recovery of total immunoglobulin and immunoglobulin subclasses in nephrotic syndrome: deflazacort vs methylprednisone [Recuperacion de la inmnoglobulina total y sus subclases en el sindrome nefrotico: 
deflazacort vs metilprednisona]. Nefrologia 2008;28(5):563. [MEDLINE: 18816222]

\section{Mattoo 2000 \{published data only\}}

* Mattoo TK, Mahmoud MA. Increased maintenance corticosteroids during upper respiratory infection decrease the risk of relapse in nephrotic syndrome. Nephron 2000;85(4):343-5. [MEDLINE: 10940745]

\section{Mishra 2012 \{published data only\}}

Mishra OP, Thakur N, Mishra RN, Prasad R. Prolonged versus standard prednisolone therapy for initial episode of idiopathic nephrotic syndrome. Journal of Nephrology 2012;25(3):394-400. [MEDLINE: 21928226]

\section{Mocan 1999 \{published data only\}}

* Mocan H, Erduran E, Karaguzel G. High dose methylprednisolone therapy in nephrotic syndrome. Indian Journal of Pediatrics 1999;66(2):171-4. [MEDLINE: 10798055]

Mocan H, Mocan MZ, Erduran E, Karaguzel G, Aslan Y. The effect of high dose methylprednisolone therapy in patients with minimal change nephrotic syndrome [abstract]. Nephrology Dialysis Transplantation 1997;12(9):A74. [CENTRAL: CN-00261380]

\section{Norero 1996 \{published data only\}}

* Norero C, Delucchi A, Lagos E, Rosati P. Initial therapy of primary nephrotic syndrome in children: evaluation in a period of 18 months of two prednisone treatment schedules. Chilean Co-operative Group of Study of Nephrotic Syndrome in Children [Cuadro inicial del sindrome nefrosico primario del nino: evaluacion a 18 meses de dos esquemas de tratamiento con prednisona. Groupo Cooperativo Chileno de Estudio del Sindrome Nefrosico del Nino]. Revista Medica de Chile 1996;124(5):567-72. [MEDLINE: 9035508]

Norero C, Delucchi A, Lagos E, Rosati P. Long term evaluation of two prednisone treatments in initial idiopathic nephrotic syndrome (INS) in children. Preliminary findings [abstract]. Pediatric Nephrology 1995;9(6):C88. [CENTRAL: CN-00550669]

\section{Pecoraro 2003 \{published data only\}}

Pecoraro C, Caropreso MR, Malgieri G, Ferretti A, Nuzzi F. Therapy of first episode steroid responsive nephrotic syndrome (FESRNS): a randomised controlled trial [abstract no: MP087]. Nephrology Dialysis Transplantation 2005;20(Suppl 5):v230. [CENTRAL: CN-00644161]

Pecoraro C, Caropreso MR, Malgieri G, Ferretti AVS, Raddi G, Piscitelli $A$, et al. Therapy of first episode of steroid responsive nephrotic syndrome: a randomised controlled trial [abstract no: OFC41]. Pediatric Nephrology 2004;19(9):C72. [CENTRAL: CN-00644160]

Pecoraro C, Caropreso MR, Passaro G, Ferretti AVS, Malgieri G. Therapy of first episode of steroid responsive nephrotic syndrome: a randomised controlled trial [abstract]. Nephrology Dialysis Transplantation 2003;18(Suppl 4):63. [CENTRAL: $\mathrm{CN}-00447140]$

\section{Satomura 2001 \{published data only\}}

Satomura K, Yamaoka K, Shima M, Tanaka Y, Ashino N, Nakagawa K, et al. Standard vs low initial dose of prednisolone therapy for first episodes of nephrotic syndrome in children [abstract]. Pediatric Nephrology 2001;16(8):C117. [CENTRAL: CN-00447593]

\section{Sharma 2000 \{unpublished data only\}}

Gulati S, Ahmed M, Sharma RK, Gupta A, Pokhariyal S. Comparison of abrupt withdrawal versus slow tapering regimen of prednisolone therapy in the management of first episode of steroid responsive childhood idiopathic nephrotic syndrome [abstract]. Nephrology Dialysis Transplantation 2001;16(6):A87. [CENTRAL: CN-00445595]

* Sharma RK, Ahmed M, Gulati S, Gupta A, Pokhariyal S. Comparison of abrupt withdrawal versus slow tapering regimen of prednisolone therapy in the management of first episode of steroid responsive childhood idiopathic nephrotic syndrome. Unpublished results 2002.

Sharma RK, Ahmed M, Gupta A, Gulati S, Sharma AP. Comparison of abrupt withdrawal versus slow tapering regimens of prednisolone therapy in management of first episode of steroid responsive childhood idiopathic nephrotic syndrome [abstract]. Journal of the American Society of Nephrology 2000;11(Sept):97A. [CENTRAL: CN-00550434]

\section{Sinha 2014 \{published and unpublished data\}}

Bagga A, Sinha A, Saha A, Kumar M, Afzal K, Mehta A, et al. Randomized double blind, placebo controlled trial to compare the efficacy of 3-months versus 6-months therapy with prednisolone for the first episode of idiopathic nephrotic syndrome (CTRI/2010/091/001095) [abstract]. Pediatric Nephrology 2012;27(9):1707. [EMBASE: 71386357]

Sinha A, Bagga A, Sharma S, Saha A, Kumar M, Afzal K, et al. Randomized, double blind, placebo controlled trial to compare the efficacy of 3-months versus 6-months therapy with prednisolone for the first episode of idiopathic nephritic syndrome [abstract]. Pediatric Nephrology 2013;28(8):1361-2. [EMBASE: 71126981]

* Sinha A, Saha A, Kumar M, Sharma S, Afzal K, Mehta A, et al. Extending initial prednisolone treatment in a randomized control trial from 3 to 6 months did not significantly influence the course of illness in children with steroid- sensitive nephrotic syndrome. Kidney International 2014;87(1):217-24. [MEDLINE: 25029428]

\section{Teeninga 2013 \{published data only\}}

Teeninga N, Kist-Van Holthe JE, Van Ruswuk N, De Mos NI, Hop WC, Wetzels JF, et al. Effect of extended prednisolone treatment from three to six months, with equal cumulative doses, on childhood nephrotic syndrome: a nation-wide randomised controlled trial [abstract]. Pediatric Nephrology 2012;27(9):1637-8. [EMBASE: 71386208]

* Teeninga N, Kist-van Holthe JE, van Rijswijk N, de Mos NI, Hop WC, Wetzels JF, et al. Extending prednisolone treatment does not reduce relapses in childhood nephrotic 
syndrome. Journal of the American Society of Nephrology 2013;24(1):149-59. [MEDLINE: 23274956]

Teeninga N, Kist-van Holthe JE, van den Akker EL, Kersten MC, Boersma $\mathrm{E}, \mathrm{Krabbe} \mathrm{HG}$, et al. Genetic and in vivo determinants of glucocorticoid sensitivity in relation to clinical outcome of childhood nephrotic syndrome. Kidney International 2014;85(6):1444-53. [MEDLINE: 24429396]

\section{Ueda 1988 \{published data only\}}

Ueda N, Chihara M, Kawaguchi S, Niimomi Y, Nonada T, Matsumoto J, et al. Intermittent versus long-term tapering prednisolone for initial therapy in children with idiopathic nephrotic syndrome. Journal of Pediatrics 1988;112(1):122-6. [MEDLINE: 3335948]

\section{Yoshikawa 1998 \{published data only\}}

Takekoshi Y. Treatment of idiopathic nephrotic syndrome [abstract]. Pediatric Nephrology 1996;10(1):C3. [CENTRAL: $\mathrm{CN}-00402800]$

* Yoshikawa N, Ito H, Takehoshi Y, Honda M, Awazu M, lijima K, et al. Standard versus long-term prednisolone with Sairei-to for initial therapy in childhood steroid-responsive nephrotic syndrome: a prospective controlled study. Nippon Jinzon Gakkai Shi. Japanese Journal of Nephrology 1998;40(8):587-90. [MEDLINE: 9893457]

Yoshikawa 2014 \{published and unpublished data\}

Yoshikawa N, Nakanishi K, Oba MS, Sako M, Ohashi Y, lijima K. Increased duration and dose of prednisolone (PSL) treatment does not reduce relapses in childhood nephrotic syndrome [abstract no: SA-PO1080]. Journal of the American Society of Nephrology 2014;24(Abstracts):3B.

* Yoshikawa N, Nakanishi K, Sako M, Oba MS, Mori R, Ota E, et al. A multicenter randomized trial indicates initial prednisolone treatment for childhood nephrotic syndrome for two months is not inferior to six-month treatment. Kidney International 2014;87(1):225-32. [MEDLINE: 25054775]

\section{Zhang 2014 \{published data only\}}

Zhang B, Liu T, Wang W, Zhang X, Fan S, Liu Z, et al. A prospective randomly controlled clinical trial on azithromycin therapy for induction treatment of children with nephrotic syndrome. European Journal of Pediatrics 2014;173(4):509-15. [MEDLINE: 24240666]

\section{References to studies excluded from this review}

\section{Alatas 1978 \{published data only\}}

Alatas H, Wirya IG, Tambunan T, Himawan S. Controlled trial of chlorambucil in frequently relapsing nephrotic syndrome in children (a preliminary report). Journal of the Medical Association of Thailand 1978;61 Suppl 1:222-8. [MEDLINE: 342654]

\section{Anonymous 1968 \{published data only\}}

Anonymous. Nephrotic syndrome in children [Die nefrotiese sindroom by kinders]. South African Medical Journal. Suid-
Afrikaanse Tydskrif Vir Geneeskunde 1968;42(2):21-2. [MEDLINE: 5637304]

\section{APN 1982 \{published data only\}}

Anonymous. Effect of cytotoxic drugs in frequently relapsing nephrotic syndrome with and without steroid dependence. New England Journal of Medicine 1982;306(8):451-4. [MEDLINE: 7035953]

Brodehl J, Krohn HP, Ehrich JH. The treatment of minimal change nephrotic syndrome (lipoid nephrosis): cooperative studies of the Arbeitsgemeinschaft fur Padiatrische Nephrologie (APN). Klinische Padiatrie 1982;194(3):162-5. [MEDLINE: 6752557]

\section{Arun 2009 \{published data only\}}

Arun S, Bagga A, Bhatnagar S, Hari P, Menon S, Saini S. Efficacy of $Z$ inc $(Z n)$ in reducing relapses in steroid sensitive nephrotic syndrome (SSNS) double blind, randomized controlled trial (RCT) (CRG030600044) [abstract no: 184OP]. Pediatric Nephrology 2007;22(9):1481. [CENTRAL: CN-00724915]

Arun S, Bhatnagar S, Menon S, Saini S, Hari P, Bagga A. Efficacy of zinc supplements in reducing relapses in steroid-sensitive nephrotic syndrome. Pediatric Nephrology 2009;24(8):1583-6. [MEDLINE: 19347367]

\section{Baluarte 1978 \{published data only\}}

Baluarte HJ, Hiner L, Gruskin AB. Chlorambucil dosage in frequently relapsing nephrotic syndrome: a controlled clinical trial. Journal of Pediatrics 1978;92(2):295-8. [MEDLINE: 621612]

\section{BAPN 1991 \{published data only\}}

Anonymous. Levamisole for corticosteroid-dependent nephrotic syndrome in childhood. British Association for Paediatric Nephrology. Lancet 1991;337(8757):1555-7. [MEDLINE: 1675705]

\section{Barratt 1970 \{published data only\}}

Barratt TM, Soothill JF. A controlled trial of cyclophosphamide in steroid sensitive relapsing nephrotic syndrome of childhood [abstract]. Nephron 1971;8:95. [CENTRAL: CN-00253521]

Barratt TM, Soothill JF. Controlled trial of cyclophosphamide in steroid-sensitive relapsing nephrotic syndrome of childhood. Lancet 1970;2(7671):479-2. [MEDLINE: 4194935]

\section{Barratt 1973 \{published data only\}}

Barratt TM, Cameron JS, Chantler C, Ogg CS, Soothill JF. Comparative trial of 2 weeks and 8 weeks cyclophosphamide in steroid-sensitive relapsing nephrotic syndrome of childhood. Archives of Disease in Childhood 1973;48(4):286-90. [MEDLINE: 4574639]

\section{Barratt 1977 \{published data only\}}

Barratt TM, Cameron JS, Chantler C, Counahan R, Ogg CS, Soothill JF. Controlled trial of azathioprine in treatment of steroid-responsive nephrotic syndrome of childhood. Archives of Disease in Childhood 1977;52(6):462-3. [MEDLINE: 879831] 


\section{Cerkauskiene 2005 \{published data only\}}

Cerkauskiene R, Kaltenis P. Comparative study of prednisolone alone and prednisolone plus fusidic acid in the treatment of children with steroid-responsive nephrotic syndrome. Medicina (Kaunas, Lithuania) 2005;41 Suppl 1:26-30. [MEDLINE: 15901972]

\section{Chiu 1973 \{published data only\}}

Chiu J, McLaine PN, Drummond KN. A controlled prospective study of cyclophosphamide in relapsing, corticosteroidresponsive, minimal-lesion nephrotic syndrome in childhood. Journal of Pediatrics 1973;82(4):607-13. [MEDLINE: 4698337]

\section{Dayal 1994 \{published data only\}}

Dayal U, Dayal AK, Shastry JC, Raghupathy P. Use of levamisole in maintaining remission in steroid-sensitive nephrotic syndrome in children [erratum appears in Nephron 1994;67(4):507]. Nephron 1994;66(4):408-12. [MEDLINE: 8015643]

\section{Donia 2005 \{published data only\}}

Donia A, Ammar H, Moustafa F, Sobh M. Long-term efficacy of two unconventional adjunctive therapies in minimal change nephrotic children [abstract]. 41st Congress. European Renal Association. European Dialysis and Transplantation Association; 2004 May 15-18; Lisbon, Portugal. 2004:37. [CENTRAL: CN-00509161]

Donia AF, Ammar HM, El Agroudy A, Moustafa F, Sobh MA. Longterm results of two unconventional agents in steroid-dependent nephrotic children. Pediatric Nephrology 2005;20(10):1420-5. [MEDLINE: 16047223]

\section{Edefonti 1988 \{published data only\}}

Edefonti A, Ghio L, Bettinelli A, Paterlini G, Giani M, Nebbia G, et al. Unconjugated hyperbilirubinemia due to ciclosporin administration in children with nephrotic syndrome. Contributions to Nephrology 1988;67:121-4. [MEDLINE: 3208520]

Edefonti A, Ghio L, Bettinelli G, Paterlini M, Giani G Nebbia A, et al. Unconjugated hyperbilirubinemia due to cyclosporin A (CYA) administration in children with nephrotic syndrome [abstract]. Pedatric Nephrology 1987;1(1):C8. [CENTRAL: CN-00465774]

Edefonti A, Ghio L, Rizzoni G, Rinaldi S, Gusmano R, Lama G, et al. Cyclosporine (CSA) vs cyclophosphamide (CYC) for children with frequently relapsing/steroid dependent nephrotic syndrome (FR/SDNS): long term study [abstract]. Journal of the American Society of Nephrology 1992;3(3):310.

Edefonti A, Ghio L, Rizzoni G, Rinaldi S, Gusmano R, Lama G, et al. Cyclosporine (CSA) vs cyclophosphamide (CYC) for children with frequently relapsing/steroid dependent nephrotic syndrome: long term study [abstract]. 9th Congress of the International Pediatric Nephrology Association; 1992 Aug 30Sep 4; Jerusalem (Israel). 1992:C70. [CENTRAL: CN-00483820]

Ponticelli C. A multicenter controlled prospective trial with cyclosporine vs cyclophosphamide in frequent relapsers and steroid dependent patients with idiopathic nephrotic syndrome. Journal of Nephrology 1989;2(2):147-51. [EMBASE: 1991014828]
Ponticelli C. Ciclosporin in the treatment of idiopathic nephrotic syndrome [abstract]. 10th Asian Colloquium in Nephrology; 1994 Dec 2-6; Karachi, Pakistan. 1994:116.

Ponticelli C, Edefonti A, Ghio L, Rizzoni G, Rinaldi S, Gusmano R, et al. Cyclosporin versus cyclophosphamide for patients with steroid-dependent and frequently relapsing idiopathic nephrotic syndrome: a multicentre randomized controlled trial. Nephrology Dialysis Transplantation 1993;8(12):1326-32. [MEDLINE: 8159300]

Ponticelli C, Rivolta E. Ciclosporin in minimal-change glomerulopathy and in focal segmental glomerular sclerosis. American Journal of Nephrology 1990;10(Suppl 1):105-9. [MEDLINE: 2256469]

\section{Grupe 1976 \{published data only\}}

Grupe WE, Makker SP, Ingelfinger JR. Chlorambucil treatment of frequently relapsing nephrotic syndrome. New England Journal of Medicine 1976;295(14):746-9. [MEDLINE: 958261]

\section{Hu 2006 \{published data only\}}

Hu GH, Dang XQ, Wang JH. Clinical effect of shenbing mistura combined with glucocorticoid on recurrent nephrotic syndrome in children and levels of interleukin- 6 and tumor necrosis factoralpha in blood and urine. Zhongguo Zhongxiyi Jiehe Zazhi [Chinese Journal of Integrated Traditional \& Western Medicine] 2006;26(10):892-5. [MEDLINE: 17121039]

\section{Idczak-Nowicka 1996 \{published data only\}}

Idczak-Nowicka E, Ksiazek J, Krynski J, Wyszynska T. Verification of indications for kidney biopsy in children with steroiddependent nephrotic syndrome [Weryfikacja wskazan do biopsji nerki u dzieci ze sterydozaleznym zespolem nerczycowym]. Pediatria Polska 1996;71(8):679-83. [MEDLINE: 8927471]

\section{ISKDC 1970 \{published data only\}}

Abramowicz M, Barnett HL, Edelmann CM Jr, Griefer I, Kobayashi O, Arneil GC, et al. Controlled trial of azathioprine in children with nephrotic syndrome. A report for the international study of kidney disease in children. Lancet 1970;1(7654):959-61. [MEDLINE: 4191931]

Arneil GC. International trial of azathioprine in nephrotic syndrome in childhood. Nephron 1971;8:95. [CENTRAL: CN-00253520]

\section{ISKDC 1974 \{published data only\}}

Anonymous. Prospective, controlled trial of cyclophosphamide therapy in children with nephrotic syndrome. Report of the International study of Kidney Disease in Children. Lancet 1974;2(7878):423-7. [MEDLINE: 4137139]

\section{Liu 1995 \{published data only\}}

Liu XY. Therapeutic effect of chai-ling-tang (sairei-to) on the steroid-dependent nephrotic syndrome in children. American Journal of Chinese Medicine 1995;23(3-4):255-60. [MEDLINE: 8571921] 
Martinelli 2004 \{published data only\}

Martinelli R, Pereira LJ, Silva OM, Okumura AS, Rocha H. Cyclophosphamide in the treatment of focal segmental glomerulosclerosis. Brazilian Journal of Medical \& Biological Research 2004;37(9):1365-72. [MEDLINE: 15334202]

\section{McCrory 1973 \{published data only\}}

McCrory WW, Shibuya M, Lu WH, Lewy JE. Therapeutic and toxic effects observed with different dosage programs of cyclophosphamide in treatment of steroid-responsive but frequently relapsing nephrotic syndrome. Journal of Pediatrics 1973;82(4):614-8. [MEDLINE: 4698338]

\section{Niaudet 1992 \{published data only\}}

Niaudet P. Comparison of cyclosporin and chlorambucil in the treatment of steroid-dependent idiopathic nephrotic syndrome: A multicentre randomized controlled trial. The French Society of Paediatric Nephrology. Pediatric Nephrology 1992;6(1):1-3. [MEDLINE: 1536727]

\section{Prasad 2004 \{published data only\}}

Prasad N, Gulati S, Sharma RK, Singh U, Ahmed M. Pulse cyclophosphamide therapy in steroid-dependent nephrotic syndrome. Pediatric Nephrology 2004;19(5):494-8. [MEDLINE: 15015070]

\section{Rashid 1996 \{published data only\}}

Rashid HU, Ahmed S, Fatima N, Khanam A. Levamisole in the treatment of steroid dependent or frequent relapsing nephrotic syndrome in children. Bangladesh Renal Journal 1996;15(1):6-8. [EMBASE: 1996266847]

\section{Sharipov 2007 \{published data only\}}

Sharipov AM, Khamzaeva KA. Current aspects of transformation of morphological changes in children with nephrotic syndrome depending on the treatment regimen. Urologiia (Moscow, Russia) 2007, (2):68-71. [MEDLINE: 17580388]

\section{Ueda 1990 \{published data only\}}

Ueda N, Kuno K, Ito S. Eight and 12 week courses of cyclophosphamide in nephrotic syndrome. Archives of Disease in Childhood 1990;65(10):1147-59. [MEDLINE: 2248508]

\section{Wang 2005 \{published data only\}}

Wang YP, Liu AM, Dai YW, Yang C, Tang HF. The treatment of relapsing primary nephrotic syndrome in children. Journal of Zhejiang University Science. B 2005;6(7):682-5. [MEDLINE: 15973773]

\section{Weiss 1993 \{published data only\}}

Weiss R. Results of a randomized, double-blind, placebo controlled, multi-center clinical trial of levamisole for the treatment of children with frequently relapsing or steroid dependent nephrotic syndrome. Personal communication 2005.

Weiss R, NY-NJ-Phila-Pediatric Nephrology Study Group. Randomized, double-blind, placebo $(\mathrm{P})$ controlled trial of levamisole $(\mathrm{L})$ for children $(\mathrm{CH})$ with frequently relapsing/ steroid dependant (FR/SD) nephrotic syndrome (NS) [abstract]. Journal of the American Society of Nephrology 1993;4(Program \& Abstracts):289. [CENTRAL: CN-00520404]

\section{Wingen 1990 \{published data only\}}

Wingen AM, Muller-Wiefel DE, Scharer K. Comparison of different regimens of prednisone therapy in frequently relapsing nephrotic syndrome. Acta Paediatrica Scandinavica 1990;79(3):305-10. [MEDLINE: 2333744]

\section{Yamashita 1971 \{published data only\}}

Yamashita F, Funatsu T, Nagayama K, Arihiro H, Anan S. Evaluation of alternate-day steroid therapy for nephrotic syndrome in childhood by cross-over study. Kurume Medical Journal 1971;18(3):153-60. [MEDLINE: 4944762]

Yang 2001 \{published data only\} Yang RY, Xu LF, Wang Q. The effect of Xuezhikang on lipid metabolism in patients with nephrotic syndrome. Hubei Yikedaxue Xuebao 2001;22(1):55-7.

\section{Yoshioka 2000 \{published data only\}}

Yoshioka K, Ohashi Y, Sakai T, Ito H, Yoshikawa N, Nakamura H, et al. A multicenter trial of mizoribine compared with placebo in children with frequently relapsing nephrotic syndrome. Kidney International 2000;58(1):317-24. [MEDLINE: 10886577]

Yoshioka K, Ohashi Y, Sakai T, Ito H, Yoshikawa N, Nakamura H, et al. Placebo-controlled trial of mizoribine (MZR) in children with frequently relapsing nephrotic syndrome (FRNS). The Pediatric Mizoribine Study Group [abstract]. Journal of the American Society of Nephrology 1998;9(Program \& Abstracts):163A.

\section{References to ongoing studies}

PREDNOS 2 Study 2014 \{published data only\}

Webb NJ, Frew E, Brettell EA, Milford DV, Bockenhauer D, Saleem MA, et al. Short course daily prednisolone therapy during an upper respiratory tract infection in children with relapsing steroid-sensitive nephrotic syndrome (PREDNOS 2): protocol for a randomised controlled trial. Trials 2014;15:147. [MEDLINE: 24767719]

\section{PREDNOS Study 2013 \{published data only\}}

Webb N, Trompeter R, Cummins C, Wheatley K, Frew E. Longterm tapering versus standard prednisolone (steroid) therapy for the treatment of the initial episode of childhood nephrotic syndrome: national multicentre randomised double-blind trial. www.controlled-trials.com/ISRCTN16645249 (accessed 26 February 2015).

\section{Additional references}

\section{Arneil 1971}

Arneil GC. The nephrotic syndrome. Pediatric Clinics of North America 1971;18(2):547-59. [MEDLINE: 4945403]

\section{Bhimma 1997}

Bhimma R, Coovadia HM, Adhikari M. Nephrotic syndrome in South African children: changing perspectives over 20 years. Pediatric Nephrology 1997;11(4):429-34. [MEDLINE: 9260239] 


\section{Bonilla-Felix 1999}

Bonilla-Felix M, Parra C, Dajani T, Ferris M, Swinford RD, Portman RJ, et al. Changing patterns in the histopathology of idiopathic nephrotic syndrome in children. Kidney International 1999;55(5):1885-90. [MEDLINE: 10231451]

\section{Eddy 2003}

Eddy AA, Symons JM. Nephrotic syndrome in childhood. Lancet 2003;362(9384):629-39. [MEDLINE: 12944064]

\section{Egger 2001}

Egger M, Dickersin K, Davey Smith G. Problems and limitations in conducting systematic reviews. In: Egger M, Davey Smith G, Altman D editor(s). Systematic Reviews in Health care: Metaanalysis in context. Second Edition. London: BMJ Publishing Group, 2001.

\section{El Bakkali 2011}

El Bakkali L, Rodrigues Pereira R, Kiuk DJ, Ket JC, van Wijk JA. Nephrotic syndrome in the Netherlands: a population-based cohort study and a review of the literature. Pediatric Nephrology 2011;26(8):1241-6. [MEDLINE: 21533870]

\section{Elzouki 1984}

Elzouki AY, Amin F, Jaiswal OP. Primary nephrotic syndrome in Arab children. Archives of Disease in Childhood 1984;59(3):253-5. [MEDLINE: 6712274]

\section{Gipson 2009}

Gipson DS, Massengill SF, Yoa L, Nagaraj S, Smoyer WE, Mahan JD, et al. Management of childhood onset nephrotic syndrome. Pediatrics 2009;124(2):747-57. [MEDLINE: 19651590]

\section{Gipson 2011}

Gipson DS, Trachtman H, Kaskel FJ, Radeva MK, Gassman J, Greene TH, et al. Clinical trials treating focal segmental glomerulosclerosis should measure patient quality of life. Kidney International 2011;79(6):678-85. [MEDLINE: 21178977]

\section{Greenbaum 2012}

Greenbaum LA, Benndorf R, Smoyer WE. Childhood nephrotic syndrome--current and future therapies. Nature Reviews Nephrology 2012;8(8):445-58. [MEDLINE: 22688744]

\section{Gulati 1999}

Gulati A, Sharma AP, Sharma RK, Gupta A. Changing trends of histopathology in childhood nephrotic syndrome. American Journal of Kidney Diseases 1999;34(4):159-65. [MEDLINE: 10516344]

\section{Haute Autorité de Santé 2008}

Haute Autorité de Santé. [Syndrome néphrotique idiopathique de l'enfant. Protocole national de diagnostic et de soinspour une maladie rare. 2008; 1-22]. www.has-sante.fr/portail/upload/ docs/application/pdf/2008-06/pnds_sni_enfant.pdf (accessed 26 February 2015).

\section{Higgins 2003}

Higgins JPT, Thompson SG, Deeks JJ, Altman DG. Measuring inconsistency in meta-analyses. BMJ 2003;327(7414):557-60. [MEDLINE: 12958120]

\section{Higgins 2011}

Higgins JP, Green S (editors). Cochrane Handbook for Systematic Reviews of Interventions Version 5.1.0 [updated March 2011]. The Cochrane Collaboration, 2011. Available from www.cochrane-handbook.org.

\section{Hopewell 2007}

Hopewell S, McDonald S, Clarke M, Egger M. Grey literature in meta-analysis of randomized trials of health care interventions. Cochrane Database of Systematic Reviews 2007, Issue 2. [DOI: 10.1002/14651858.MR000010.pub3]

\section{Hyams 1988}

Hyams JS, Carey DE. Corticosteroids and growth. Journal of Pediatrics 1988;113(2):249-54. [MEDLINE: 3294360]

\section{IPNG-IAP 2008}

Indian Pediatric Nephrology Group, Indian Academy of Pediatrics, Bagga A, Ali U, Banerjee S, Kanitkar M, Phadke KD, et al. Management of steroid sensitive nephrotic syndrome: revised guidelines. Indian Pediatrics 2008;45(3):203-14. [MEDLINE: 18367765]

\section{ISKDC 1984}

Anonymous. Minimal change nephrotic syndrome in children: deaths during the first 5-15 years' observation. Report of the International Study of Kidney Disease in Children. Pediatrics 1984;73(4):497-501. [MEDLINE: 6709428]

\section{KDIGO 2012}

Lombel RM, Gipson DS, Hodson EM, Kidney Disease: Improving Global Outcomes. Treatment of steroid-sensitive nephrotic syndrome: new guidelines from KDIGO. Pediatric Nephrology 2013;28(3):415-26. [MEDLINE: 23052651]

\section{Kim 2005}

Kim JS, Bellew CA, Silverstein DM, Aviles DH, Boineau FG, Vehaskari VM. High incidence of initial and late steroid resistance in childhood nephrotic syndrome. Kidney International 2005;68(3):1275-81. [MEDLINE: 16105061]

\section{Koskimies 1982}

Koskimies O, Vilska J, Rapola J, Hallman N. Long-term outcome of primary nephrotic syndrome. Archives of Disease in Childhood 1982;57(7):544-8. [MEDLINE: 7103547]

\section{MacHardy 2009}

MacHardy N, Miles PV, Massengill SF, Smoyer WE, Mahan JD, Greenbaum L, et al. Management patterns of childhood-onset nephrotic syndrome. Pediatric Nephrology 2009;24(11):2193-201. [MEDLINE: 19672630]

\section{McKinney 2001}

McKinney PA, Feltbower RG, Brocklebank JT, Fitzpatrick MM. Time trends and ethnic patterns of childhood nephrotic syndrome in Yorkshire, UK. Pediatric Nephrology 2001;16(12):1040-4. [MEDLINE: 11793096] 


\section{Mehls 2011}

Mehls O, Hoyer PF. Dosing of glucocorticosteroids in nephrotic syndrome. Pediatric Nephrology 2011;26(12):2095-8. [MEDLINE: 21904778]

\section{Mishra 2010}

Mishra OM, Basu B, Upadhyay SK, Prasad R, Schaefer F. Behavioural abnormalities in children with nephrotic syndrome. Nephrology Dialysis Transplantation 2010;25(8):2537-41. [MEDLINE: 20200003]

\section{Moher 1998}

Moher D, Pham B, Jones A, Cook DJ, Jadad AR, Moher M, et al. Does quality of reports of randomised trials affect estimates of intervention efficacy reported in meta-analyses?. Lancet 1998;352(9128):609-13. [MEDLINE: 9746022]

\section{Moher 2001}

Moher D, Jones A, Lepage L, CONSORT Group (Consolidated Standards for Reporting of Trials). Use of the CONSORT statement and quality of reports of randomized trials: a comparative before-and-after evaluation. JAMA 2001;285(15):1992-5. [MEDLINE: 11308436]

\section{Neuhaus 2010}

Neuhaus TJ, Langlois V, Licht C. Behavioural abnormalities in children with nephrotic syndrome--an underappreciated complication of a standard treatment?. Nephrology Dialysis Transplantation 2010;25(8):2397-9. [MEDLINE: 20573807]

\section{Ng 2001}

Ng JS, Wong W, Law RW, Hui J, Wong EN, Lam DS. Ocular complications of paediatric patients with nephrotic syndrome. Clinical \& Experimental Ophthalmology 2001;29(4):239-43. [MEDLINE: 11545423]

\section{Niaudet 2009}

Niaudet P. Long-term outcome of children with steroid-sensitive idiopathic nephrotic syndrome. Clinical Journal of The American Society of Nephrology: CJASN 2009;4(10):1457-8. [MEDLINE: 19808239]

\section{Pravitsitthikul 2013}

Pravitsitthikul N, Willis NS, Hodson EM, Craig JC. Noncorticosteroid immunosuppressive medications for steroidsensitive nephrotic syndrome in children. Cochrane Database of Systematic Reviews 2013, Issue 10. [DOI: 10.1002/14651858.CD002290.pub4]

\section{Rüth 2005}

Rüth EM, Kemper M, Leumann EP, Laube GF, Neuhaus TJ. Children with steroid sensitive nephrotic syndrome come of age: long-term outcome. Journal of Pediatrics 2005;147(2):202-7. [MEDLINE: 16126050]

\section{Samuel 2013}

Samuel S, Morgan CJ, Bitzan N, Mammen C, Dart AB, Manns BJ, et al. Substantial practice variation exists in the management of childhood nephrotic syndrome. Pediatric Nephrology 2013;29(12):2289-98. [MEDLINE: 23917450]

\section{Schulz 1995}

Schulz KF, Chalmers I, Hayes RJ, Altman DG. Empirical evidence of bias. Dimensions of methodological quality associated with estimates of treatment effects in controlled trials. JAMA 1995;273(5):408-12. [MEDLINE: 7823387]

\section{Srivastava 1999}

Srivastava T, Simon SD, Alon US. High incidence of focal segmental glomerulosclerosis in nephrotic syndrome of childhood. Pediatric Nephrology 1999;13(1):13-8. [MEDLINE: 10100283]

\section{Tarshish 1997}

Tarshish P, Tobin JN, Bernstein J, Edelmann CM Jr. Prognostic significance of the early course of minimal change nephrotic syndrome: report of the International Study of Kidney Disease in Children. Journal of the American Society of Nephrology 1997;8(5):769-76. [MEDLINE: 9176846]

\section{References to other published versions of this review Hodson 2000}

Hodson EM, Knight JF, Willis NS, Craig JC. Corticosteroid therapy in nephrotic syndrome: a meta-analysis of randomised controlled trials. Archives of Disease in Childhood 2000;83(1):45-51. [MEDLINE: 10868999]

\section{Hodson 2002}

Hodson EM, Knight JF, Willis NS, Craig JC. Corticosteroid therapy for nephrotic syndrome in children. Cochrane Database of Systematic Reviews 2002, Issue 3. [DOI: 10.1002/14651858.CD001533]

\section{Hodson 2003}

Hodson EM, Knight JF, Willis NS, Craig JC. Corticosteroid therapy for nephrotic syndrome in children. Cochrane Database of Systematic Reviews 2003, Issue 2. [DOI: 10.1002/14651858.CD001533.pub2]

\section{Hodson 2005}

Hodson EM, Knight JF, Willis NS, Craig JC. Corticosteroid therapy for nephrotic syndrome in children. Cochrane Database of Systematic Reviews 2005, Issue 1. [DOI: 10.1002/14651858.CD001533.pub3]

\section{Hodson 2007}

Hodson EM, Willis NS, Craig JC. Corticosteroid therapy for nephrotic syndrome in children. Cochrane Database of Systematic Reviews 2007, Issue 4. [DOI: 10.1002/14651858.CD001533.pub4]

* Indicates the major publication for the study 
CHARACTERISTICS OF STUDIES

Characteristics of included studies [ordered by study ID]

Abeyagunawardena 2008

\begin{tabular}{|c|c|}
\hline Methods & $\begin{array}{l}\text { - Study design: cross-over RCT } \\
\text { - Time frame: July } 2003 \text { to January 2005. Study continued until } 40 \text { children had } 2 \text { URTIs } \\
\text { - Duration of follow-up: until child had } 2 \text { URTI }\end{array}$ \\
\hline Participants & $\begin{array}{l}\text { - Country: Sri Lanka } \\
\text { - Setting: single tertiary referral centre } \\
\text { - Inclusion criteria: children aged } 1 \text { to } 16 \text { y with FRNS receiving maintenance low dose (0.1 to } 0.6 \mathrm{mg} / \\
\text { kg) alternate-day oral prednisolone } \\
\text { - Number: } 40 \\
\text { - Median age (range): } 5.3 \text { years ( } 1.5 \text { to } 13.2) \\
\text { - Sex (M/F): } 29 / 11 \\
\text { - Exclusion criteria: glucocorticoid related side effects; frequent relapses requiring steroid sparing } \\
\text { agents, did not have two viral infections within study period, sustained remission with disease stability }\end{array}$ \\
\hline Interventions & $\begin{array}{l}\text { Treatment group } \\
\text { - Prednisolone } 5 \mathrm{mg} \text { daily for } 7 \text { days at onset of viral infection } \\
\text { Control group } \\
\text { - Placebo daily for } 7 \text { days } \\
\text { Randomised at onset of URTI to receive one of the interventions. At next URTI received alternate thera- } \\
\text { py }\end{array}$ \\
\hline Outcomes & $\begin{array}{l}\text { - Number relapsing during } 6 \text { months of therapy and in subsequent } 6 \text { months } \\
\text { - Mean relapse rate during treatment and in subsequent } 6 \text { months }\end{array}$ \\
\hline Notes & $\begin{array}{l}\text { Definitions } \\
\text { * FRNS: } 2+\text { relapses within } 6 \text { months of first response or } 4 \text { relapses in any } 1 \text { year (ISKDC definition) } \\
\text { previously been in remission } \\
\text { * Remission: urinary protein excretion negative or trace on urinalysis for } 3 \text { consecutive days } \\
\text { * URTI: presence of } 3 \text { or more of the following criteria - cough, runny nose, sore throat, lethargy, body } \\
\text { aches and fever }\end{array}$ \\
\hline
\end{tabular}

\section{Risk of bias}

\begin{tabular}{lll}
\hline Bias & Authors' judgement & Support for judgement \\
\hline $\begin{array}{l}\text { Random sequence genera- } \\
\text { tion (selection bias) }\end{array}$ & Low risk & Randomly allocated, sealed envelopes, sequential patients \\
\hline $\begin{array}{l}\text { Allocation concealment } \\
\text { (selection bias) }\end{array}$ & Low risk & Randomly allocated, sealed envelopes \\
\hline $\begin{array}{l}\text { Blinding of participants } \\
\text { and personnel (perfor- } \\
\text { mance bias) }\end{array}$ & Low risk & Investigators and parents blinded to contents of containers \\
All outcomes & & \\
\hline
\end{tabular}

Blinding of outcome as-
sessment (detection bias) $\quad$ Low risk Investigators and parents blinded to contents of containers


Abeyagunawardena 2008 (Continued)

All outcomes

\begin{tabular}{lll}
$\begin{array}{l}\text { Incomplete outcome data } \\
\text { (attrition bias) } \\
\text { All outcomes }\end{array}$ & High risk & $\begin{array}{l}8 / 48 \text { excluded from study (17\%) for need for additional immunosuppression } \\
(4), \text { no second viral infection (3), number without further relapses (1) }\end{array}$ \\
\hline $\begin{array}{l}\text { Selective reporting (re- } \\
\text { porting bias) }\end{array}$ & High risk & $\begin{array}{l}\text { Not all the review's pre-specified outcomes were recorded; no mention of ad- } \\
\text { verse events }\end{array}$ \\
\hline Other bias & Low risk & The study appears to be free of other source of bias
\end{tabular}

\section{Abeyagunawardena 2014}

\begin{tabular}{ll} 
Methods & - Study design: cross-over RCT \\
& - Time frame: not reported \\
\hline Participants & - Country: Sri Lanka \\
& - Setting: tertiary referral university centre \\
- Inclusion criteria: children with FRNS off prednisone for 3 months & 24 months \\
- Number: 48 & \\
- Mean age \pm SD (years): treatment group $(12.0 \pm 2.4)$; control group $(10.0 \pm 2.9)$ \\
- Sex: not reported \\
- Exclusion criteria: children with SSNS receiving alternate-day prednisone
\end{tabular}

$\begin{array}{ll}\text { Interventions } & \text { Treatment group } \\ \text { - Prednisolone } 0.5 \mathrm{mg} / \mathrm{kg} / \mathrm{d} \text { for } 5 \text { days at start of each URTI for } 12 \text { months and then crossed over to } \\ \text { control group }\end{array}$

Control group

- Placebo for 5 days at start of each URTI for 12 months and then crossed over to treatment group

\begin{tabular}{ll}
\hline Outcomes & Number of relapses associated with URTI in each year \\
\hline Notes & - Abstract only \\
& - Definitions of SDNS, URTI and relapse not reported \\
\hline
\end{tabular}

\section{Risk of bias}

\begin{tabular}{lll}
\hline Bias & Authors' judgement & Support for judgement \\
\hline $\begin{array}{l}\text { Random sequence genera- } \\
\text { tion (selection bias) }\end{array}$ & Unclear risk & Said to be randomised \\
\hline $\begin{array}{l}\text { Allocation concealment } \\
\text { (selection bias) }\end{array}$ & Unclear risk & Said to be randomised \\
\hline $\begin{array}{l}\text { Blinding of participants } \\
\text { and personnel (perfor- } \\
\text { mance bias) }\end{array}$ & Low risk & Placebo administered to control group \\
All outcomes & & \\
\hline
\end{tabular}


Abeyagunawardena 2014 (Continued)
Blinding of outcome as-
Low risk
Placebo administered to control group sessment (detection bias)

All outcomes

\begin{tabular}{lll}
\hline $\begin{array}{l}\text { Incomplete outcome data } \\
\text { (attrition bias) } \\
\text { All outcomes }\end{array}$ & High risk & $15 / 48(31 \%)$ did not complete both parts of the 2 year cross-over study \\
\hline $\begin{array}{l}\text { Selective reporting (re- } \\
\text { porting bias) }\end{array}$ & High risk & $\begin{array}{l}\text { No report of adverse effects; cross-over study and no separate results avail- } \\
\text { able for first part of the study so results could not be included in meta-analyses }\end{array}$ \\
\hline Other bias & Unclear risk & Abstract only; no information provided \\
\hline
\end{tabular}

\section{APN 1981}

\begin{tabular}{ll}
\hline Methods & - Study design: parallel RCT \\
& - Time frame: not reported \\
& - Duration of follow-up: 12 months \\
\hline Participants & - Country: northern Europe \\
- Setting: multicentre, renal clinics \\
- Inclusion criteria: children with FRNS \\
- Number (analysed/randomised): treatment group $1(23 / 30)$; treatment group $2(25 / 34)$ \\
- Mean age \pm SD (months): treatment group $1(88.5 \pm 33.0) ;$ treatment group $2(101.3 \pm 35.1)$ \\
- Sex (M/F): treatment group 1 (15/8); treatment group $2(18 / 7)$ \\
- Exclusion criteria: not reported
\end{tabular}

\begin{tabular}{|c|c|}
\hline Interventions & $\begin{array}{l}\text { Treatment group } 1 \text { (alternate) } \\
\text { - Prednisone: } 60 \mathrm{mg} / \mathrm{m}^{2} / \mathrm{d} \text { till protein free for } 3+\text { days; then } 35 \mathrm{mg} / \mathrm{m}^{2} \text { on alternate days } \\
\text { - Total duration: } 6 \text { months } \\
\text { Treatment group } 2 \\
\text { - Prednisone: } 60 \mathrm{mg} / \mathrm{m}^{2} / \mathrm{d} \text { till protein free for } 3+\text { days; then } 40 \mathrm{mg} / \mathrm{m}^{2} \text { given on } 3 / 7 \text { consecutive days } \\
\text { - Total duration: } 6 \text { months }\end{array}$ \\
\hline Outcomes & $\begin{array}{l}\text { - Number relapsing during } 6 \text { months of therapy and in subsequent } 6 \text { months } \\
\text { - Mean relapse rate during treatment and in subsequent } 6 \text { months }\end{array}$ \\
\hline Notes & $\begin{array}{l}\text { Definitions } \\
\text { * } \text { FRNS: } 2+\text { relapses within } 6 \text { months of first response or } 4 \text { relapses in any } 1 \text { year (ISKDC definition) } \\
* \text { Relapse: urine protein }>40 \mathrm{mg} / \mathrm{m}^{2} / \mathrm{h} \text { for } 3 \text { consecutive days (ISKDC) } \\
* \text { Remission: urinary protein }<4 \mathrm{mg} / \mathrm{m}^{2} / \mathrm{h} \text { for } 3 \text { consecutive days (ISKDC) }\end{array}$ \\
\hline
\end{tabular}

\section{Risk of bias}

\begin{tabular}{lll}
\hline Bias & Authors' judgement & Support for judgement \\
\hline $\begin{array}{l}\text { Random sequence genera- } \\
\text { tion (selection bias) }\end{array}$ & Unclear risk & Insufficient information about sequence generation to permit judgement \\
\hline $\begin{array}{l}\text { Allocation concealment } \\
\text { (selection bias) }\end{array}$ & Low risk & $\begin{array}{l}\text { Sealed envelopes provided to each centre. "One opened when patient quali- } \\
\text { fied to enter the study" }\end{array}$ \\
\hline
\end{tabular}




\section{APN 1981 (Continued)}

Blinding of participants and personnel (performance bias)

All outcomes
High risk Blinding no mentioned and the outcome is likely to be influenced by lack of blinding

$\begin{array}{lll}\text { Blinding of outcome as- } & \text { High risk } & \begin{array}{l}\text { Blinding of outcome assessment not mentioned and outcome measurement } \\ \text { sessment (detection bias) }\end{array} \\ \text { All outcomes } & \text { likely to be influenced by lack of blinding }\end{array}$
All outcomes

Incomplete outcome data High risk (attrition bias)

All outcomes

Selective reporting (re- Low risk
porting bias)
16/64 withdrawn: steroid toxicity (8); incorrect treatment or uncooperative parents (6); late non-response (1); one patient unaccounted for in the text

Other bias Low risk Supported by grants from the VW Foundation

APN 1988

\begin{tabular}{|c|c|}
\hline Methods & $\begin{array}{l}\text { - Study design: parallel RCT } \\
\text { - Time frame: not reported } \\
\text { - Duration of follow-up: } 2 \text { years }\end{array}$ \\
\hline Participants & $\begin{array}{l}\text { - Country: northern Europe } \\
\text { - Setting: multicentre, renal clinics } \\
\text { - Inclusion criteria: children with initial episode SSNS } \\
\text { - Number: treatment group } 1 \text { (32); treatment group } 2(29) \\
\text { - Age range: } 2 \text { to } 16 \text { years } \\
\text { - Sex (M/F): not reported } \\
\text { - Exclusion criteria: parents. previous treatment with corticosteroids or immunosuppressive agents; } \\
\text { any contraindications to corticosteroid therapy }\end{array}$ \\
\hline Interventions & $\begin{array}{l}\text { Treatment group } 1 \text { (4weeks) } \\
\text { - Prednisone: } 60 \mathrm{mg} / \mathrm{m}^{2} / \mathrm{d} \text { till urine protein-free for } 3 \text { days then } 40 \mathrm{mg} / \mathrm{m}^{2} \text { on alternate days till albumin } \\
>35 \mathrm{~g} / \mathrm{L} \\
\text { - Total duration: about } 1 \text { month } \\
\text { Treatment group } 2 \text { ( } 8 \text { weeks) } \\
\text { - Prednisone } 60 \mathrm{mg} / \mathrm{m}^{2} / \mathrm{d} \text { for } 4 \text { weeks and then } 40 \mathrm{mg} / \mathrm{m}^{2} \text { on alternate days for } 4 \text { weeks } \\
\text { - Total duration: } 2 \text { months }\end{array}$ \\
\hline Outcomes & $\begin{array}{l}\text { - Number of patients with/without relapse at } 6 \text { months and } 1 \text { year after completing daily prednisone } \\
\text { - Number relapses/patient/y } \\
\text { - Time to first relapse } \\
\text { - Number becoming frequent relapsing patients } \\
\text { - Number with serious adverse events }\end{array}$ \\
\hline
\end{tabular}


APN 1988 (Continued)

$$
\begin{aligned}
& \text { - Definitions } \\
& * \text { FRNS using ISKDC definition } \\
& \text { * Relapse: ISKDC definition } \\
& * \text { Remission: ISKDC definition with albumin } \geq 35 \mathrm{~g} / \mathrm{L}
\end{aligned}
$$

\begin{tabular}{|c|c|c|}
\hline $\begin{array}{l}\text { Incomplete outcome data } \\
\text { (attrition bias) } \\
\text { All outcomes }\end{array}$ & High risk & $\begin{array}{l}\text { " } 77 \text { patients were initially recruited into the trial, but } 16 \text { had to be removed at } \\
\text { an early stage due to steroid resistance (8), or early deviations from the treat- } \\
\text { ment protocol } \\
\text { (8)" }\end{array}$ \\
\hline
\end{tabular}

\section{Risk of bias}

\begin{tabular}{lll}
\hline Bias & Authors' judgement & Support for judgement \\
\hline $\begin{array}{l}\text { Random sequence genera- } \\
\text { tion (selection bias) }\end{array}$ & Unclear risk & Insufficient information about sequence generation to permit judgement \\
\hline $\begin{array}{l}\text { Allocation concealment } \\
\text { (selection bias) }\end{array}$ & Low risk & "Central random allocation" reported \\
\hline $\begin{array}{l}\text { Blinding of participants } \\
\text { and personnel (perfor- } \\
\text { mance bias) }\end{array}$ & High risk & $\begin{array}{l}\text { Blinding not mentioned and the outcome is likely to be influenced by lack of } \\
\text { All outcomes }\end{array}$ \\
\hline
\end{tabular}

\begin{tabular}{lll}
\hline $\begin{array}{l}\text { Blinding of outcome as- } \\
\text { sessment (detection bias) }\end{array}$ & High risk & $\begin{array}{l}\text { Blinding of outcome assessment not mentioned and outcome measurement } \\
\text { All outcomes }\end{array}$ \\
\hline
\end{tabular}
(8)"

"34 patients completed the study for the full 2 years. Data for the other 27 patients were included for the period that they remained in the study protocol. Of the 27, 5 patients of the short-course group and 4 from the standard group were removed when they required other immunosuppressive agents; 2 patients from each group left the country during the course of the study; 7 children from the short-course group, and 3 from the standard group, were lost to follow-up due to failure of continuous parental cooperation; and late treatment faults were observed in 3 cases after short-course treatment, and in 1 patient after standard therapy. The full course was completed by 15 patients receiving the short course and by 19 receiving standard treatment."

\begin{tabular}{lll}
\hline $\begin{array}{l}\text { Selective reporting (re- } \\
\text { porting bias) }\end{array}$ & High risk & $\begin{array}{l}\text { Did not report all the review's pre-specified outcomes. No report on number of } \\
\text { FRNS }\end{array}$ \\
\hline Other bias & Low risk & Supported by grants from the VW Foundation \\
\hline
\end{tabular}

\begin{tabular}{ll}
\hline Methods & Study design: parallel RCT \\
& - Time frame: not reported \\
& - Duration of follow-up: 2 years \\
\hline Participants & Country: northern Europe \\
- Setting: multicentre, renal clinics \\
- Inclusion criteria: children with initial episode SSNS \\
- Number: treatment group 1 (34); treatment group 2 (37) \\
\hline
\end{tabular}


APN 1993 (Continued)

- Sex (M/F): not reported

- Exclusion criteria: previous treatment with corticosteroids or immunosuppressive agents; contraindications to corticosteroid therapy

\begin{tabular}{|c|c|}
\hline Interventions & $\begin{array}{l}\text { Treatment group } 1 \text { ( } 3 \text { months) } \\
\text { - Prednisone: } 60 \mathrm{mg} / \mathrm{m}^{2} / \mathrm{d} \text { for } 6 \text { weeks and then } 40 \mathrm{mg} / \mathrm{m}^{2} \text { on alternate days for } 6 \text { weeks } \\
\text { - Total duration: } 3 \text { months } \\
\text { Treatment group } 2 \text { ( } 2 \text { months) } \\
\text { - Prednisone: } 60 \mathrm{mg} / \mathrm{m}^{2} / \mathrm{d} \text { for } 4 \text { weeks and then } 40 \mathrm{mg} / \mathrm{m}^{2} \text { on alternate days for } 4 \text { weeks } \\
\text { - Total duration: } 2 \mathrm{months}\end{array}$ \\
\hline Outcomes & $\begin{array}{l}\text { - Number of patients with/without relapse by } 6 \text { and } 12 \text { months after completing daily and alternate-day } \\
\text { - Nrednisone } \\
\text { - Number becoming frequent relapsers } \\
\text { - Number of serious adverse events }\end{array}$ \\
\hline Notes & $\begin{array}{l}\text { - Complete one year follow-up } \\
\text { - Definitions } \\
* \text { FRNS: ISKDC definition } \\
* \text { Relapse: ISKDC definition } \\
* \text { Remission: ISKDC definition }\end{array}$ \\
\hline
\end{tabular}

\section{Risk of bias}

\begin{tabular}{|c|c|c|}
\hline Bias & Authors' judgement & Support for judgement \\
\hline $\begin{array}{l}\text { Random sequence genera- } \\
\text { tion (selection bias) }\end{array}$ & Low risk & Central random allocation \\
\hline $\begin{array}{l}\text { Allocation concealment } \\
\text { (selection bias) }\end{array}$ & Low risk & Central random allocation \\
\hline $\begin{array}{l}\text { Blinding of participants } \\
\text { and personnel (perfor- } \\
\text { mance bias) } \\
\text { All outcomes }\end{array}$ & High risk & $\begin{array}{l}\text { Blinding not mentioned and the outcome is likely to be influenced by lack of } \\
\text { blinding }\end{array}$ \\
\hline $\begin{array}{l}\text { Blinding of outcome as- } \\
\text { sessment (detection bias) } \\
\text { All outcomes }\end{array}$ & High risk & $\begin{array}{l}\text { Blinding of outcome assessment not mentioned and outcome measurement } \\
\text { likely to be influenced by lack of blinding }\end{array}$ \\
\hline $\begin{array}{l}\text { Incomplete outcome data } \\
\text { (attrition bias) } \\
\text { All outcomes }\end{array}$ & Low risk & $\begin{array}{l}7.7 \% \text { excluded for protocol violation. This proportion of missing outcomes are } \\
\text { not sufficient to impact results }\end{array}$ \\
\hline $\begin{array}{l}\text { Selective reporting (re- } \\
\text { porting bias) }\end{array}$ & Low risk & Reported the review's pre-specified outcomes \\
\hline Other bias & Unclear risk & Insufficient information to assess \\
\hline
\end{tabular}

APN 1999

Methods - Study design: parallel RCT


APN 1999 (Continued)

- Time frame: NS

- Follow-up period: 2 years

\begin{tabular}{|c|c|}
\hline Participants & $\begin{array}{l}\text { - Country: northern Europe } \\
\text { - Setting: multicentre tertiary services } \\
\text { - Inclusion criteria: children aged } 1 \text { to } 16 \mathrm{y} \text {; first episode of SSNS (albumin < } 25 \mathrm{~g} / \mathrm{L} \text {, proteinuria }>40 \mathrm{mg} / \\
\mathrm{kg} / \mathrm{h}) ; \mathrm{GFR}>68 \mathrm{~mL} / \mathrm{min} / 1.73 \mathrm{~m}^{2} \\
\text { - Number (analysed/randomised): treatment group } 1(49 / 62) \text {; treatment group } 2(55 / 65) \\
\text { - Mean age } \pm \mathrm{SD} \text { (years): treatment group } 1(5.1 \pm 2.8) \text {; treatment group } 2(5.6 \pm 3.2) \\
\text { - Sex (M/F): not reported } \\
\text { - Exclusion criteria: SRNS; post infectious glomerulonephritis; secondary nephrotic syndrome; no pre- } \\
\text { vious steroids/immunosuppressives, no contraindication to these }\end{array}$ \\
\hline
\end{tabular}

Interventions

Treatment group 1

- CSA: $150 \mathrm{mg} / \mathrm{m}^{2} / \mathrm{d}$ for 8 weeks; dose altered to achieve levels 80 to $150 \mathrm{ng} / \mathrm{mL}$

- Prednisone: $60 \mathrm{mg} / \mathrm{m}^{2} / \mathrm{d}$ for 6 weeks; $40 \mathrm{mg} / \mathrm{m}^{2}$ on alternate days for 6 weeks

* Total duration: 12 weeks

Treatment group 2

- Prednisone $60 \mathrm{mg} / \mathrm{m}^{2} / \mathrm{d}$ for 6 weeks; $40 \mathrm{mg} / \mathrm{m}^{2}$ on alternate days for 6 weeks

* Total duration 12 weeks

\begin{tabular}{ll}
\hline Outcomes & - Number of patients with relapse and mean relapse rate at 6, 12 months \\
- Median time to relapse \\
- Adverse effects of CSA \\
- ISKDC and APN definitions of remission/relapse used \\
- Cumulative steroid dose \\
- Adverse effects \\
\hline Notes & - Stop or end point/s: need for CPA treatment \\
\end{tabular}

\section{Risk of bias}

\begin{tabular}{|c|c|c|}
\hline Bias & Authors' judgement & Support for judgement \\
\hline $\begin{array}{l}\text { Random sequence genera- } \\
\text { tion (selection bias) }\end{array}$ & Low risk & Co-ordinating centre, centrally allocated \\
\hline $\begin{array}{l}\text { Allocation concealment } \\
\text { (selection bias) }\end{array}$ & Low risk & Centrally allocated \\
\hline $\begin{array}{l}\text { Blinding of participants } \\
\text { and personnel (perfor- } \\
\text { mance bias) } \\
\text { All outcomes }\end{array}$ & High risk & $\begin{array}{l}\text { No blinding reported and the outcome is likely to be influenced by lack of } \\
\text { blinding }\end{array}$ \\
\hline $\begin{array}{l}\text { Blinding of outcome as- } \\
\text { sessment (detection bias) } \\
\text { All outcomes }\end{array}$ & High risk & $\begin{array}{l}\text { No blinding of outcome assessment reported and outcome measurement like- } \\
\text { ly to be influenced by lack of blinding }\end{array}$ \\
\hline $\begin{array}{l}\text { Incomplete outcome data } \\
\text { (attrition bias) } \\
\text { All outcomes }\end{array}$ & High risk & 152 randomised, 25 withdrew consent ( 127 entered study) \\
\hline
\end{tabular}


Prednisone group: 10/65 (15\%) excluded (infection (1), SRNS (7), protocol deviation (1), unstated (1))

\begin{tabular}{|c|c|c|}
\hline $\begin{array}{l}\text { Selective reporting (re- } \\
\text { porting bias) }\end{array}$ & High risk & $\begin{array}{l}\text { Not all of review's pre-specified outcomes have been reported. No report on } \\
\text { number of frequently relapsing nephrotic syndrome (FRNS). Adverse events } \\
\text { and outcomes in reported in percentages }\end{array}$ \\
\hline
\end{tabular}

Other bias Unclear risk Insufficient information to assess whether an important risk of bias exists

\section{Bagga 1999}

\begin{tabular}{ll} 
Methods & Study design: parallel RCT \\
- & Time frame: September 1992 to June 1995 \\
- & Follow-up: minimum of 1 year from completion of initial therapy \\
\hline Participants & Country: India \\
- Setting: renal clinic \\
- Inclusion criteria: children aged 1 to 12 y with first episode SSNS \\
- Number (analysed/randomised): treatment group 1 (22/24); treatment group 2 (23/27) \\
- Sean age \pm SD (years): not reported \\
- Exclusion criteria: received corticosteroids or immunosuppressive agents; showing features of an un- \\
derlying systemic disease (e.g., systemic lupus erythematosus, Henoch-Schönlein purpura, amyloi- \\
dosis, vasculitis, and hereditary glomerular diseases); haematuria (> 5 red cells/high-power field of \\
a centrifuged specimen); persistent hypertension (blood pressure more than the 95 th percentile for \\
height for age on three or more occasions); $\mathrm{CrCl}<80 \mathrm{~mL} /$ min $/ 1.73$ m²
\end{tabular}

\begin{tabular}{|c|c|}
\hline Interventions & $\begin{array}{l}\text { Treatment group } 1 \text { ( } 4 \text { months) } \\
\text { - Prednisolone: } 2 \mathrm{mg} / \mathrm{kg} / \mathrm{d} \text { for } 4 \text { weeks, } 1.5 \mathrm{mg} / \mathrm{kg} / \mathrm{d} \text { for } 4 \text { weeks then } 1.5 \mathrm{mg} / \mathrm{kg} \text { alternate days for } 4 \\
\text { weeks, } 1 \mathrm{mg} / \mathrm{kg} \text { alternate days for } 4 \text { weeks } \\
\text { - Total duration: } 4 \text { months } \\
\text { Treatment group } 2 \text { ( } 2 \text { months) } \\
\text { - Prednisolone: } 2 \mathrm{mg} / \mathrm{kg} / \mathrm{d} \text { for } 4 \text { weeks then } 1.5 \mathrm{mg} / \mathrm{kg} \text { on alternate days for } 4 \text { weeks } \\
\text { - Total } 2 \text { months }\end{array}$ \\
\hline Outcomes & $\begin{array}{l}\text { - Number of patients with/without relapse by } 6 \text { and } 12 \text { months after completing daily and alternate-day } \\
\text { prednisolone } \\
\text { - Number becoming frequent relapsers } \\
\text { - Relapse rate/patient/year; mean time to first relapse } \\
\text { - Number of serious adverse events } \\
\text { - Cumulative steroid dose }\end{array}$ \\
\hline Notes & $\begin{array}{l}\text { - Complete one year follow-up } \\
\text { - Definitions } \\
\text { * FRNS: } 2+\text { relapses in } 6 \text { months or } 3+\text { within } 12 \text { months of initial episode } \\
* \text { Relapse: } 3+\text { protein on dipstick for } 3 \text { consecutive days } \\
* \text { Remission: nil or trace of protein on dipstick for } 3+\text { consecutive days }\end{array}$ \\
\hline
\end{tabular}


Bagga 1999 (Continued)

Risk of bias

\begin{tabular}{|c|c|c|}
\hline Bias & Authors' judgement & Support for judgement \\
\hline $\begin{array}{l}\text { Random sequence genera- } \\
\text { tion (selection bias) }\end{array}$ & Low risk & Information from author that sequence generation was random \\
\hline $\begin{array}{l}\text { Allocation concealment } \\
\text { (selection bias) }\end{array}$ & Low risk & Information from author that allocation occurred after child had entered study \\
\hline $\begin{array}{l}\text { Blinding of participants } \\
\text { and personnel (perfor- } \\
\text { mance bias) } \\
\text { All outcomes }\end{array}$ & High risk & $\begin{array}{l}\text { Blinding not mentioned and the outcome is likely to be influenced by lack of } \\
\text { blinding }\end{array}$ \\
\hline $\begin{array}{l}\text { Blinding of outcome as- } \\
\text { sessment (detection bias) } \\
\text { All outcomes }\end{array}$ & High risk & $\begin{array}{l}\text { Blinding of outcome assessment not mentioned and outcome measurement } \\
\text { likely to be influenced by lack of blinding }\end{array}$ \\
\hline $\begin{array}{l}\text { Incomplete outcome data } \\
\text { (attrition bias) } \\
\text { All outcomes }\end{array}$ & Low risk & Withdrawal/lost to follow-up: 6/51; steroid resistance (4); poor compliance (2) \\
\hline $\begin{array}{l}\text { Selective reporting (re- } \\
\text { porting bias) }\end{array}$ & Low risk & All the review's pre-specified outcomes have been reported \\
\hline Other bias & Low risk & $\begin{array}{l}\text { Research grant from the All India Institute of Medical Sciences, New Delhi, In- } \\
\text { dia. The study appears to be free of other source of bias }\end{array}$ \\
\hline
\end{tabular}

Broyer 1997

\begin{tabular}{ll}
\hline Methods & Study design: parallel RCT \\
- Time period: not reported \\
- Follow-up: 1 year \\
\hline Participants & Country: France \\
- Setting: multicentre, renal clinics \\
- Inclusion criteria: children with SDNS (2+ relapses in 12 months despite alternate-day prednisone or \\
within 2 months of stopping this regimen). \\
- Number: treatment group $1(20)$; treatment group $2(20)$ \\
- Mean age \pm SD (years): treatment group 1 (9.2 \pm 2.7$) ;$ treatment group $2(8.5 \pm 4)$ \\
- Exclusion criteria: not reported
\end{tabular}

Interventions

Treatment group 1

- Deflazacort: dose equivalent to prednisone of $60 \mathrm{mg} / \mathrm{m}^{2} / \mathrm{d}$ till in remission for 5 days then $60 \mathrm{mg} / \mathrm{m}^{2}$ on alternate days for 6 weeks, taper 6 to 8 weeks then 15 to $20 \mathrm{mg} / \mathrm{m}^{2}$ on alternate days for 1 year

Treatment group 2

- Prednisone given as above

Outcomes

- Number relapsing during 1 year of therapy

- Mean relapse rate/patient 
Broyer 1997 (Continued)

$$
\text { - Serious adverse events }
$$

Notes $\quad$ Six children in treatment group and 5 in control group also received cyclosporin

- Definitions

* Relapse: not reported

* Remission: not reported

\section{Risk of bias}

\begin{tabular}{|c|c|c|}
\hline Bias & Authors' judgement & Support for judgement \\
\hline $\begin{array}{l}\text { Random sequence genera- } \\
\text { tion (selection bias) }\end{array}$ & Low risk & $\begin{array}{l}\text { "Blocks of } 10 \text { packages containing equal numbers of each intervention in or- } \\
\text { der determined by random code" }\end{array}$ \\
\hline $\begin{array}{l}\text { Allocation concealment } \\
\text { (selection bias) }\end{array}$ & Low risk & "Block randomisation and sealed packages, lots of $10 "$ \\
\hline $\begin{array}{l}\text { Blinding of participants } \\
\text { and personnel (perfor- } \\
\text { mance bias) } \\
\text { All outcomes }\end{array}$ & Low risk & $\begin{array}{l}\text { Blinding of participants and key study personnel ensured. "Medication in iden- } \\
\text { tical bottles and identical tablets" }\end{array}$ \\
\hline $\begin{array}{l}\text { Blinding of outcome as- } \\
\text { sessment (detection bias) } \\
\text { All outcomes }\end{array}$ & Low risk & Blinding of outcome assessment ensured. "Blinded until end of study" \\
\hline $\begin{array}{l}\text { Incomplete outcome data } \\
\text { (attrition bias) } \\
\text { All outcomes }\end{array}$ & Low risk & $\begin{array}{l}\text { Withdrawal/lost to follow-up: } 2 / 40 \text { (loss to follow-up (1); protocol treatment } \\
\text { deviation (1)) }\end{array}$ \\
\hline $\begin{array}{l}\text { Selective reporting (re- } \\
\text { porting bias) }\end{array}$ & Low risk & $\begin{array}{l}\text { All the review's pre-specified outcomes have been reported (cannot report on } \\
\text { SDNS, as all remained on steroids as per protocol). }\end{array}$ \\
\hline Other bias & Unclear risk & Insufficient information to assess whether an important risk of bias exists \\
\hline
\end{tabular}

\section{Ekka 1997}

$\begin{array}{ll}\text { Methods } & \text { - Study design: parallel RCT } \\ \text { - Time frame: December } 1993 \text { to June } 1995 \\ \text { - Follow-up: } 9 \text { months }\end{array}$

\begin{tabular}{ll}
\hline Participants & Country: India \\
- Setting: renal clinic \\
- Inclusion criteria: children aged 1.3 to 17 y with relapsing SSNS \\
- Number (analysed/randomised): treatment group $1(47 / 52)$; treatment group $2(48 / 54)$ \\
- Mean age \pm SD (years): treatment group $1(5.6 \pm 2.8) ;$ treatment group $2(6.6 \pm 3.4)$ \\
- Sex (M/F): treatment group 1 (32/15); treatment group $2(31 / 16)$ \\
- Exclusion criteria: received corticosteroids or other immunosuppressive drugs for treatment of the \\
current relapse; steroid resistance or dependence
\end{tabular}

\footnotetext{
Interventions

Treatment group 1 (single dose)

- Prednisolone: $2 \mathrm{mg} / \mathrm{kg} / \mathrm{d}$ for 2 to 4 weeks given as single morning dose and then $1.5 \mathrm{mg} / \mathrm{kg}$ on alternate days for 4 weeks
} 
Ekka 1997 (Continued)

Treatment group 2 (divided dose)

- Prednisolone: $2 \mathrm{mg} / \mathrm{kg} / \mathrm{d}$ for 2 to 4 weeks given as 3 divided doses and then $1.5 \mathrm{mg} / \mathrm{kg}$ on alternate days for 4 weeks

\begin{tabular}{ll}
\hline Outcomes & Number with/without relapse at 9 months \\
& - Time to remission \\
\hline Notes & Duration of remission \\
& $*$ Definitions \\
& $*$ Relapse: urine protein $2+$ on dipstick for 3 consecutive days \\
& \\
\hline
\end{tabular}

\section{Risk of bias}

\begin{tabular}{|c|c|c|}
\hline Bias & Authors' judgement & Support for judgement \\
\hline $\begin{array}{l}\text { Random sequence genera- } \\
\text { tion (selection bias) }\end{array}$ & Unclear risk & $\begin{array}{l}\text { "Randomised " - insufficient information about sequence generation process } \\
\text { to permit judgement }\end{array}$ \\
\hline $\begin{array}{l}\text { Allocation concealment } \\
\text { (selection bias) }\end{array}$ & Unclear risk & Randomisation stated but no information on method used is available \\
\hline $\begin{array}{l}\text { Blinding of participants } \\
\text { and personnel (perfor- } \\
\text { mance bias) } \\
\text { All outcomes }\end{array}$ & High risk & $\begin{array}{l}\text { Blinding not mentioned and the outcome is likely to be influenced by lack of } \\
\text { blinding }\end{array}$ \\
\hline $\begin{array}{l}\text { Blinding of outcome as- } \\
\text { sessment (detection bias) } \\
\text { All outcomes }\end{array}$ & High risk & $\begin{array}{l}\text { Blinding of outcome assessment not mentioned and outcome measurement } \\
\text { likely to be influenced by lack of blinding }\end{array}$ \\
\hline $\begin{array}{l}\text { Incomplete outcome data } \\
\text { (attrition bias) } \\
\text { All outcomes }\end{array}$ & High risk & $\begin{array}{l}\text { Withdrawal/lost to follow-up: 12/106; did not report for follow-up (11); steroid } \\
\text { resistant (1) }\end{array}$ \\
\hline $\begin{array}{l}\text { Selective reporting (re- } \\
\text { porting bias) }\end{array}$ & Low risk & All the review's pre-specified outcomes have been reported. \\
\hline Other bias & Unclear risk & Insufficient information to assess whether an important risk of bias exists \\
\hline
\end{tabular}

Gulati 2009

\begin{tabular}{ll}
\hline Methods & Study design: parallel RCT \\
& - Time frame: September 2006 to October 2009 \\
\hline Participants & Duration of follow-up: 24 months \\
\hline - Country: India \\
- Setting: single tertiary centre \\
amisole given to those requiring > $1 \mathrm{mg} / \mathrm{kg}$ prednisolone on alternate days, who had $\geq 1$ feature of \\
steroid toxicity \\
- Number (analysed/randomised): treatment group 1 (49/50); treatment group 2 (46/50) \\
- Mean age \pm SD (months): treatment group 1 (78.5 \pm 35.6$) ;$ treatment group 2 (81.7 \pm 38.7$)$ \\
- Sex (M/F): treatment group 1 (35/15); treatment group 2 (32/18)
\end{tabular}


- Exclusion criteria: impaired renal function $(\mathrm{SCr}>1.2 \mathrm{mg} / \mathrm{dl})$, immunosuppressives other than oral prednisone in preceding 6 months; steroid threshold $>1 \mathrm{mg} / \mathrm{kg}$ on alternate days to maintain remission with more than one feature of steroid toxicity, e.g. cataracts; BMI > 95th percentile for age; stage 2 hypertension

\begin{tabular}{ll}
\hline Interventions & Treatment group 1 \\
- & Existing prednisolone alternate-day dose increased to a daily dose for 7 days at onset of viral infection \\
& Treatment group 2 \\
- & Prednisolone continued at same alternate-day dose at onset of viral infection \\
\hline Outcomes & Rates of infection-associated relapses expressed as episodes/patient year \\
- & Total number of relapses/patient-year \\
- & Frequency and types of infection \\
- Cumulative dose of prednisone received in both groups & Definitions \\
$*$ & FRNS: at least 2 relapses in 6 months, or $>3$ relapses in 12 months \\
$*$ & Viral infection: one or more of fever, rhinorrhoea or cough, diarrhoea \\
$*$ & Infection related relapse: presence of $3+$ to $4+$ proteinuria for 3 consecutive days occurring in the \\
& week after 7 days of onset of an infective illness \\
$*$ & Remission: trace/negative protein for 3 consecutive days
\end{tabular}

\section{Risk of bias}

\begin{tabular}{|c|c|c|}
\hline Bias & Authors' judgement & Support for judgement \\
\hline $\begin{array}{l}\text { Random sequence genera- } \\
\text { tion (selection bias) }\end{array}$ & Low risk & $\begin{array}{l}\text { Block randomisation. "randomised by stratified randomisation" on basis of } \\
\text { therapy with or without levamisole }\end{array}$ \\
\hline $\begin{array}{l}\text { Allocation concealment } \\
\text { (selection bias) }\end{array}$ & Low risk & "allocation was concealed with opaque sealed envelopes opened at inclusion" \\
\hline $\begin{array}{l}\text { Blinding of participants } \\
\text { and personnel (perfor- } \\
\text { mance bias) } \\
\text { All outcomes }\end{array}$ & High risk & $\begin{array}{l}\text { Blinding not mentioned and the outcome is likely to be influenced by lack of } \\
\text { blinding }\end{array}$ \\
\hline $\begin{array}{l}\text { Blinding of outcome as- } \\
\text { sessment (detection bias) } \\
\text { All outcomes }\end{array}$ & High risk & $\begin{array}{l}\text { Blinding of outcome assessment not mentioned and outcome measurement } \\
\text { likely to be influenced by lack of blinding }\end{array}$ \\
\hline $\begin{array}{l}\text { Incomplete outcome data } \\
\text { (attrition bias) } \\
\text { All outcomes }\end{array}$ & High risk & $\begin{array}{l}11 / 100(11 \%) \text { patients excluded or lost to follow-up; lost to follow-up (5), dis- } \\
\text { continued treatment }(6)\end{array}$ \\
\hline $\begin{array}{l}\text { Selective reporting (re- } \\
\text { porting bias) }\end{array}$ & Low risk & All the review's pre-specified outcomes have been reported \\
\hline Other bias & Low risk & Funded by the Indian Council of Medical Research. CTRI/2008/091/000245 \\
\hline
\end{tabular}

\section{Hiraoka 2000}

Methods - Study design: parallel RCT


Hiraoka 2000 (Continued)

- Time frame: December 1993 to August 1996

- Follow-up: 2 years

\begin{tabular}{ll}
\hline Participants & Country: Japan \\
- Setting: multicentre, renal clinics \\
- Inclusion criteria: children with initial episode of SSNS. Eight excluded because steroid resistant \\
- Number (analysed/randomised): treatment group $1(30 / 34)$; treatment group $2(29 / 34)$ \\
- Mean age \pm SD (years): treatment group $1(6.4 \pm 3.4) ;$ treatment group $2(7.1 \pm 4.0)$ \\
- Sex (M/F): treatment group $1(21 / 13)$; treatment group $2(21 / 13)$ \\
- Exclusion criteria: not reported
\end{tabular}

\begin{tabular}{ll}
\hline Interventions & Treatment group 1 (high dose) \\
- Prednisolone: $60 \mathrm{mg} / \mathrm{m}^{2} / \mathrm{d}\left(\mathrm{max} 80 \mathrm{mg}\right.$ ) for 6 weeks, $40 \mathrm{mg} / \mathrm{m}^{2}$ on alternate days for 6 weeks \\
- Total duration: $3 \mathrm{months}$ \\
Treatment group 2 (standard) \\
- Prednisolone: $40 \mathrm{mg} / \mathrm{m}^{2} / \mathrm{d}$ (max $60 \mathrm{mg}$ ) for 6 weeks, $40 \mathrm{mg} / \mathrm{m}^{2}$ on alternate days for 6 weeks \\
- Total duration: $3 \mathrm{months}$ \\
- Number relapsing at $6 \mathrm{months}$ and $12 \mathrm{months}$ \\
- Number with frequent relapses \\
- Adverse effects \\
- Definitions \\
$*$ Relapse: Urine protein $2+$ for $3 \mathrm{days}$. \\
$*$ Remission: Urine protein $<4 \mathrm{mg} / \mathrm{h} / \mathrm{m}^{2}$ for 3 days or $\mathrm{more}$
\end{tabular}

\section{Risk of bias}

\begin{tabular}{|c|c|c|}
\hline Bias & Authors' judgement & Support for judgement \\
\hline $\begin{array}{l}\text { Random sequence genera- } \\
\text { tion (selection bias) }\end{array}$ & Unclear risk & $\begin{array}{l}\text { "Randomly allocated " - insufficient information about sequence generation } \\
\text { process to permit judgement }\end{array}$ \\
\hline $\begin{array}{l}\text { Allocation concealment } \\
\text { (selection bias) }\end{array}$ & Unclear risk & Randomisation stated but no information on method used is available \\
\hline $\begin{array}{l}\text { Blinding of participants } \\
\text { and personnel (perfor- } \\
\text { mance bias) } \\
\text { All outcomes }\end{array}$ & High risk & $\begin{array}{l}\text { Blinding not mentioned and the outcome is likely to be influenced by lack of } \\
\text { blinding }\end{array}$ \\
\hline $\begin{array}{l}\text { Blinding of outcome as- } \\
\text { sessment (detection bias) } \\
\text { All outcomes }\end{array}$ & High risk & $\begin{array}{l}\text { Blinding of outcome assessment not mentioned and outcome measurement } \\
\text { likely to be influenced by lack of blinding }\end{array}$ \\
\hline $\begin{array}{l}\text { Incomplete outcome data } \\
\text { (attrition bias) } \\
\text { All outcomes }\end{array}$ & Low risk & $\begin{array}{l}\text { No missing outcome data } \\
\text { Withdrawal/lost to follow-up: } 8 / 68 \text { excluded for steroid resistance }\end{array}$ \\
\hline $\begin{array}{l}\text { Selective reporting (re- } \\
\text { porting bias) }\end{array}$ & Low risk & All the review's pre-specified outcomes have been reported \\
\hline Other bias & Unclear risk & Insufficient information to assess whether an important risk of bias exists \\
\hline
\end{tabular}


Hiraoka 2003

\begin{tabular}{|c|c|}
\hline Methods & $\begin{array}{l}\text { - Study design: parallel RCT } \\
\text { - Time frame: August } 1996 \text { and May } 1999 \\
\text { - Follow-up: } 2 \text { years }\end{array}$ \\
\hline Participants & $\begin{array}{l}\text { - Country: Japan } \\
\text { - Setting: multicentre renal clinics } \\
\text { - Inclusion criteria: children with initial episode of SSNS } \\
\text { - Number (analysed/randomised): treatment group } 1 \text { ( } 36 / 38) \text {; treatment group } 2(34 / 35) \\
\text { - Mean age } \pm \text { SD (years): treatment group } 1(7.6 \pm 4.5) \text {; treatment group } 2(7.4 \pm 4.4) \\
\text { - Sex (M/F): treatment group } 1 \text { ( } 25 / 13) \text {; treatment group } 2(22 / 13) \\
\text { - Exclusion criteria: not reported }\end{array}$ \\
\hline Interventions & $\begin{array}{l}\text { Treatment group } 1 \text { (long duration) } \\
\text { - Prednisolone: } 60 \mathrm{mg} / \mathrm{m}^{2} / \mathrm{d} \text { (max } 80 \mathrm{mg} \text { ) for } 4 \text { weeks; } 60 \mathrm{mg} / \mathrm{m}^{2} \text { (max } 80 \mathrm{mg} \text { ) on alternate days for } 4 \\
\text { weeks and reducing by } 10 \mathrm{mg} / \mathrm{m}^{2} \text { each month } \\
\text { - Total duration: } 28 \text { weeks } \\
\text { - Total calculated dose: } 4620 \mathrm{mg} / \mathrm{m}^{2} \\
\text { Treatment group } 2 \text { (standard duration) } \\
\text { - Prednisolone: } 60 \mathrm{mg} / \mathrm{m}^{2} / \mathrm{d} \text { for } 6 \text { weeks ( } \max 80 \mathrm{mg} \text { ); } 40 \mathrm{mg} / \mathrm{m}^{2} \text { (max } 60 \mathrm{mg} \text { ) on alternate days for } 6 \\
\text { - Teeks } \\
\text { - Total duration: } 12 \text { weeks }\end{array}$ \\
\hline Outcomes & $\begin{array}{l}\text { - Number relapsing at 6,12 and } 24 \text { months } \\
\text { - Number with FRNS } \\
\text { - Adverse effects }\end{array}$ \\
\hline Notes & $\begin{array}{l}\text { Definitions } \\
* \text { Relapse: urine protein } 2+\text { for } 3 \text { days } \\
* \text { Remission: urine protein }<4 \mathrm{mg} / \mathrm{h} / \mathrm{m}^{2} \text { for } 3 \text { days or more }\end{array}$ \\
\hline
\end{tabular}

\section{Risk of bias}

\section{Bias}

Random sequence genera- Low risk tion (selection bias)

Allocation concealment Low risk
(selection bias)

\begin{tabular}{|c|c|c|}
\hline $\begin{array}{l}\text { Blinding of participants } \\
\text { and personnel (perfor- } \\
\text { mance bias) } \\
\text { All outcomes }\end{array}$ & High risk & $\begin{array}{l}\text { Blinding not mentioned and the outcome is likely to be influenced by lack of } \\
\text { blinding }\end{array}$ \\
\hline $\begin{array}{l}\text { Blinding of outcome as- } \\
\text { sessment (detection bias) } \\
\text { All outcomes }\end{array}$ & High risk & $\begin{array}{l}\text { Blinding of outcome assessment not mentioned and outcome measurement } \\
\text { likely to be influenced by lack of blinding }\end{array}$ \\
\hline
\end{tabular}


Hiraoka 2003 (Continued)
Incomplete outcome data Low risk
Withdrawal/ lost to follow-up: 3/73; steroid resistance (3)
(attrition bias)
Withdrawal/lost to follow-up:3/73, steroid resistance (3)

All outcomes

Selective reporting (re- Low risk $\quad$ All the review's pre-specified outcomes have been reported
porting bias)

\begin{tabular}{lll}
\hline Other bias $\quad$ Unclear risk & Insufficient information to assess whether an important risk of bias exists \\
\hline
\end{tabular}

Imbasciati 1985

\begin{tabular}{ll}
\hline Methods & Study design: parallel RCT \\
- Time frame: June 1980 to June 1983 \\
- Follow-up: 12 to 24 months \\
\hline Participants & Country: Italy \\
- Setting: multicentre, renal clinics \\
- Inclusion criteria: children aged 2 to 14 y with either initial episode SSNS or no relapse in previous year \\
- Number (analysed/randomised): treatment group 1 (33/44); treatment group 2 (34/45) \\
- Median age, range (years): treatment group 1 ( 9 , 2 to 54$) ;$ treatment group 2 (8, 2 to 56$)$ \\
- Exclusion criteria: evidence of underlying systemic disease, neoplasia, viral hepatitis, or exposure to \\
\\
drugs or toxic agents known to induce the nephrotic syndrome; treated with steroids or cytotoxic \\
agents within one year before admission
\end{tabular}

- Methylprednisolone: $20 \mathrm{mg} / \mathrm{kg}$ IV for 3 days, prednisone $20 \mathrm{mg} / \mathrm{m}^{2} / \mathrm{d}$ for 4 weeks, $20 \mathrm{mg} / \mathrm{m}^{2}$ on alternate days for 4 weeks then $20 \mathrm{mg} / \mathrm{m}^{2}$ on alternate days for 4 months

- Total duration: 6 months

Treatment group 2

- Prednisone: $60 \mathrm{mg} / \mathrm{m}^{2} / \mathrm{d}$ for 4 weeks, $40 \mathrm{mg} / \mathrm{m}^{2}$ on alternate days for 4 weeks and $20 \mathrm{mg} / \mathrm{m}^{2}$ on alternate days for 4 months

- Total duration: 6 months

\begin{tabular}{ll}
\hline Outcomes & Number with/without relapse during 12-24 months follow-up \\
& - Mean relapse rate/patient/year \\
\hline Notes & Adults also in study. Some end points not separated for children so not examined \\
& $*$ Definitions \\
& $*$ Relapse: ISKDC \\
& $*$ Remission: ISKDC \\
\hline
\end{tabular}

\section{Risk of bias}

\begin{tabular}{lll}
\hline Bias & Authors' judgement & Support for judgement \\
\hline $\begin{array}{l}\text { Random sequence genera- } \\
\text { tion (selection bias) }\end{array}$ & Low risk & "Randomly assigned from a table with random numbers" \\
\hline $\begin{array}{l}\text { Allocation concealment } \\
\text { (selection bias) }\end{array}$ & Low risk & Central randomisation centre \\
\hline \hline
\end{tabular}


Imbasciati 1985 (Continued)

Blinding of participants High risk Blinding not mentioned and the outcome is likely to be influenced by lack of and personnel (perforblinding mance bias)

All outcomes

\section{Blinding of outcome as- High risk} sessment (detection bias)

All outcomes

Blinding of outcome assessment not mentioned and outcome measurement likely to be influenced by lack of blinding
Incomplete outcome data Low risk (attrition bias)

All outcomes

Selective reporting (re-

Selective reporting (re- Low risk porting bias)
No missing outcome data. All 89 randomised patients followed for 12-24 months

Other bias Unclear risk Insufficient information to assess whether an important risk of bias exists

\section{ISKDC 1979}

\begin{tabular}{ll}
\hline Methods & Study design: parallel RCT \\
& - Time frame: 20 September 1973 to 26 August 1976 \\
& - Follow-up: at least 8 months
\end{tabular}

- Country: USA and Northern Europe
- Setting: multicentre, renal clinics
- Inclusion criteria: children aged 3 mo to $15 \mathrm{y}$ with SSNS within 6 months of their initial response to
steroid therapy
- Number (analysed/randomised): treatment group 1 (28/32); treatment group 2 (26/32)
- Mean age $\pm \mathrm{SD}$ (years): not reported
- Sex (M/F): not reported
- Exclusion criteria: proteinuria $\leq 40 \mathrm{mg} / \mathrm{h} / \mathrm{m}^{2}$; hypoalbuminaemia $\geq 2.5 \mathrm{~g} / \mathrm{dL}$ at the onset of their dis-
ease; prior treatment with steroids or other cytotoxic immunosuppressant agents; evidence of under-
lying systemic disease or exposure to agents associated with the nephrotic syndrome

- Prednisone: $60 \mathrm{mg} / \mathrm{m}^{2} / \mathrm{d}$ for 4 weeks and tapered daily dose for 4 weeks

Control group

- Prednisone: $60 \mathrm{mg} / \mathrm{m}^{2} / \mathrm{d}$ till remission and $40 \mathrm{mg} / \mathrm{m}^{2}$ on $3 / 7$ consecutive days

\begin{tabular}{ll}
\hline Outcomes & Number relapsing during treatment and within 12 months \\
& - Mean time to next relapse \\
\hline Notes & Mean relapse rate/patient \\
& $*$ Refinitions \\
& $*$ Remission: ISKDC definition \\
\hline
\end{tabular}

\section{Risk of bias}


Jayantha 2002a (Continued)

Notes

- Abstract and data from author

- Definitions

* ISKDC (relapse): proteinuria $\geq 2+$ for $5+$ days

* Remission: oedema free and urine protein negative/trace

* FRNS and SDNS: ISKDC and APN definitions

\section{Risk of bias}

\begin{tabular}{|c|c|c|}
\hline Bias & Authors' judgement & Support for judgement \\
\hline $\begin{array}{l}\text { Random sequence genera- } \\
\text { tion (selection bias) }\end{array}$ & Low risk & "Random allocation table" - notes received from author \\
\hline $\begin{array}{l}\text { Allocation concealment } \\
\text { (selection bias) }\end{array}$ & Unclear risk & Insufficient information provided \\
\hline $\begin{array}{l}\text { Blinding of participants } \\
\text { and personnel (perfor- } \\
\text { mance bias) } \\
\text { All outcomes }\end{array}$ & High risk & $\begin{array}{l}\text { Blinding not mentioned and the outcome is likely to be influenced by lack of } \\
\text { blinding }\end{array}$ \\
\hline $\begin{array}{l}\text { Blinding of outcome as- } \\
\text { sessment (detection bias) } \\
\text { All outcomes }\end{array}$ & High risk & $\begin{array}{l}\text { Blinding of outcome assessment not mentioned and outcome measurement } \\
\text { likely to be influenced by lack of blinding }\end{array}$ \\
\hline $\begin{array}{l}\text { Incomplete outcome data } \\
\text { (attrition bias) } \\
\text { All outcomes }\end{array}$ & High risk & Withdrawal/loss to follow-up: $46 / 135$ (34\%) lost to follow-up at 2 years \\
\hline $\begin{array}{l}\text { Selective reporting (re- } \\
\text { porting bias) }\end{array}$ & Low risk & Reported on all of review's pre-specified outcomes \\
\hline Other bias & Unclear risk & Insufficient information to assess whether an important risk of bias exists \\
\hline
\end{tabular}

Jayantha 2002b

\begin{tabular}{ll}
\hline Methods & Study design: parallel RCT \\
& - Time frame: September 1994 to September 2002 \\
\hline Participants & Follow-up: 6 months \\
\hline & - Country: Sri Lanka. \\
- Setting: renal clinic \\
- Inclusion criteria: children with relapsing SSNS; patients with SDNS \\
- Age range: 1 to 11.1 years \\
- Sex (M/F): $50 / 45$ \\
- Exclusion criteria: not reported
\end{tabular}

- Prednisolone: $60 \mathrm{mg} / \mathrm{m}^{2} / \mathrm{d}$ for 4 weeks, then $60 \mathrm{mg} / \mathrm{m}^{2}$ on alternate days. Reducing alternate-day dose by $10 \mathrm{mg} / \mathrm{m}^{2}$ every 4 weeks

- Total duration: 7 months 
- ISKDC regimen: prednisolone $60 \mathrm{mg} / \mathrm{m}^{2} / \mathrm{d}$ till urine protein-free for 3 days, then $40 \mathrm{mg} / \mathrm{m}^{2}$ on alternate days for 4 weeks

- Total duration: 2 months

\begin{tabular}{ll}
\hline Outcomes & Number relapsing by 6,12 and 24 months \\
- & Relapse rate/patient/y \\
- & Number with frequent relapses, steroid dependence at 1 year \\
- & Adverse effects \\
\hline Notes & Abstract and data from author \\
- Definitions & $*$ SKDC-relapse: proteinuria $\geq 2+$ for $5+$ days \\
& $*$ Remission: oedema free and urine protein negative/trace \\
& $*$ FRNS, SSNS and SDNS: ISKDC and APN definitions \\
\hline
\end{tabular}

\section{Risk of bias}

Bias Authors' judgement Support for judgement

Random sequence genera- Low risk $\quad$ "random allocation table". Information from author
tion (selection bias)

tion (selection bias)

$\begin{aligned} & \text { Allocation concealment } \\ & \text { (selection bias) }\end{aligned}$ Unclear risk Randomisation stated but no information on allocation concealment provided

\begin{tabular}{|c|c|c|}
\hline $\begin{array}{l}\text { Blinding of participants } \\
\text { and personnel (perfor- }\end{array}$ & High risk & $\begin{array}{l}\text { Blinding not mentioned and the outcome is likely to be influenced by lack of } \\
\text { blinding }\end{array}$ \\
\hline
\end{tabular}
mance bias)

All outcomes

$\begin{array}{lll}\text { Blinding of outcome as- } & \text { High risk } & \begin{array}{l}\text { Blinding of outcome assessment not mentioned and outcome measurement } \\ \text { likely to be influenced by lack of blinding }\end{array} \\ \text { All outcomes } & \end{array}$

\begin{tabular}{lll}
\hline $\begin{array}{l}\text { Incomplete outcome data } \\
\text { (attrition bias) } \\
\text { All outcomes }\end{array}$ & High risk & 24\% lost to follow-up at 1 year (23/95) \\
\hline $\begin{array}{l}\text { Selective reporting (re- } \\
\text { porting bias) }\end{array}$ & High risk & $\begin{array}{l}\text { Not all the review's pre-specified outcomes have been reported. No report on } \\
\text { adverse effects }\end{array}$ \\
\hline Other bias & Unclear risk & Insufficient information to assess whether an important risk of bias exists \\
\hline
\end{tabular}

Kleinknecht 1982

\begin{tabular}{ll}
\hline Methods & Study design: parallel RCT \\
& - Time frame: not reported \\
& Follow-up:15 months \\
\hline Participants & - Country: France \\
& - Setting: multicentre, renal clinics \\
& Inclusion criteria: children with initial episode SSNS \\
\hline
\end{tabular}


Kleinknecht 1982 (Continued)

- Number: treatment group 1 (29); treatment group 2 (29)

- Mean age \pm SD (years): not reported

- Sex (M/F): not reported

- Exclusion criteria: not reported

Interventions Treatment group 1 (13 months)

- Prednisone: $2 \mathrm{mg} / \mathrm{kg} / \mathrm{d}$ for 4 weeks and then tapering dose on alternate days for 12 months

Treatment group 2 (6 months)

- Prednisone: $2 \mathrm{mg} / \mathrm{kg} / \mathrm{d}$ for 4 weeks and then tapering dose on alternate days for 5 months

\begin{tabular}{ll}
\hline Outcomes & - Number relapsing by 6,12 and 15 months or more \\
\hline Notes & - Abstract only \\
& - Authors confirmed adequate allocation but unable to supply further study information \\
& - Definitions of FRNS /SSNS /relapse /remission: not reported
\end{tabular}

\section{Risk of bias}

\begin{tabular}{|c|c|c|}
\hline Bias & Authors' judgement & Support for judgement \\
\hline $\begin{array}{l}\text { Random sequence genera- } \\
\text { tion (selection bias) }\end{array}$ & Low risk & $\begin{array}{l}\text { 'Sealed closed number envelopes in series of ten". Information obtained from } \\
\text { author }\end{array}$ \\
\hline $\begin{array}{l}\text { Allocation concealment } \\
\text { (selection bias) }\end{array}$ & Low risk & Central randomisation \\
\hline $\begin{array}{l}\text { Blinding of participants } \\
\text { and personnel (perfor- } \\
\text { mance bias) } \\
\text { All outcomes }\end{array}$ & High risk & $\begin{array}{l}\text { Blinding not reported and the outcome is likely to be influenced by lack of } \\
\text { blinding }\end{array}$ \\
\hline $\begin{array}{l}\text { Blinding of outcome as- } \\
\text { sessment (detection bias) } \\
\text { All outcomes }\end{array}$ & High risk & $\begin{array}{l}\text { Blinding of outcome assessment not reported and outcome measurement } \\
\text { likely to be influenced by lack of blinding }\end{array}$ \\
\hline $\begin{array}{l}\text { Incomplete outcome data } \\
\text { (attrition bias) } \\
\text { All outcomes }\end{array}$ & Unclear risk & Insufficient information to permit judgement \\
\hline $\begin{array}{l}\text { Selective reporting (re- } \\
\text { porting bias) }\end{array}$ & High risk & $\begin{array}{l}\text { Not all review's pre-specified outcomes have been reported. } \\
\text { No data on adverse effects }\end{array}$ \\
\hline Other bias & Unclear risk & Insufficient information to assess whether an important risk of bias exists \\
\hline
\end{tabular}

\section{Ksiazek 1995}

\begin{tabular}{ll}
\hline Methods & - Study design: parallel RCT \\
& - Time frame: not reported \\
& - Follow-up: two years \\
\hline Participants & - Country: Poland \\
& - Setting: renal clinic \\
\hline
\end{tabular}


Ksiazek 1995 (Continued)

- Inclusion criteria: children with initial episode SSNS

- Number: treatment group 1 (72); treatment group 2 (68); treatment group 3 (44)

- Mean age (range): 3.6 years (13 months to 11 years)

- Sex (M/F): 113/71

- Exclusion criteria: not reported

\begin{tabular}{|c|c|}
\hline Interventions & $\begin{array}{l}\text { Treatment group } 1 \text { ( } 6 \text { months) } \\
\text { - Prednisone: } 1 \text { to } 2 \mathrm{mg} / \mathrm{kg} / \mathrm{d} \text { for } 4 \text { weeks, } 1 \mathrm{mg} / \mathrm{kg} \text { on alternate days for } 4 \text { weeks and taper by } 25 \% \text { each } \\
\text { month for } 4 \text { months } \\
\text { - Total duration: } 6 \text { months } \\
\text { - Total calculated steroid dose } 2922 \mathrm{mg} / \mathrm{m}^{2} \\
\text { Treatment group } 2 \text { ( } 3 \text { months) } \\
\text { - Prednisone } 1 \text { to } 2 \mathrm{mg} / \mathrm{kg} / \mathrm{d} \text { for } 4 \text { weeks, } 1 \mathrm{mg} / \mathrm{kg} \text { on alternate days for } 4 \text { weeks and taper by } 25 \% / \text { week } \\
\text { for } 4 \text { weeks. } \\
\text { - Total duration: } 3 \text { months } \\
\text { - Total calculated steroid dose } 2410 \mathrm{mg} / \mathrm{m}^{2} \\
\text { Treatment group } 3 \text { ( } 2 \text { months) } \\
\text { - Prednisone } 4 \text { weeks each of } 1 \text { to } 2 \mathrm{mg} / \mathrm{kg} / \mathrm{d} \text { and } 1 \mathrm{mg} / \mathrm{kg} \text { on alternate days } \\
\text { - Total duration: } 2 \text { months }\end{array}$ \\
\hline Outcomes & $\begin{array}{l}\text { - Number relapsing by } 6 \text { months and } 2 \text { years after completing daily and alternate-day prednisone } \\
\text { - Relapse rate/patient/y }\end{array}$ \\
\hline Notes & $\begin{array}{l}\text { - Unequal numbers in groups } \\
\text { - Only treatment group } 2 \text { used in analyses } \\
* \text { Definitions } \\
* \text { FRNS: ISKDC definition } \\
* \text { Relapse: ISKDC definition } \\
* \text { Remission: ISKDC definition }\end{array}$ \\
\hline
\end{tabular}

\section{Risk of bias}

\begin{tabular}{lll}
\hline Bias & Authors' judgement & Support for judgement \\
\hline $\begin{array}{l}\text { Random sequence genera- } \\
\text { tion (selection bias) }\end{array}$ & Unclear risk & $\begin{array}{l}\text { "randomly assigned", insufficient information about sequence generation to } \\
\text { permit judgement }\end{array}$ \\
\hline
\end{tabular}

\begin{tabular}{lll}
\hline $\begin{array}{l}\text { Allocation concealment } \\
\text { (selection bias) }\end{array}$ & High risk & "Parents had an influence on assignment, favouring Protocol C" \\
\hline $\begin{array}{l}\text { Blinding of participants } \\
\text { and personnel (perfor- } \\
\text { mance bias) }\end{array}$ & High risk & $\begin{array}{l}\text { Blinding not reported and the outcome is likely to be influenced by lack of } \\
\text { blinding }\end{array}$ \\
All outcomes &
\end{tabular}

\begin{tabular}{|c|c|c|}
\hline $\begin{array}{l}\text { Blinding of outcome as- } \\
\text { sessment (detection bias) } \\
\text { All outcomes }\end{array}$ & High risk & $\begin{array}{l}\text { Blinding of outcome assessment not reported and outcome measurement } \\
\text { likely to be influenced by lack of blinding }\end{array}$ \\
\hline
\end{tabular}

Incomplete outcome data Low risk All patients followed for two years
(attrition bias)
All outcomes


Ksiazek 1995 (Continued)

Selective reporting (re- High risk Not all review's pre-specified outcomes have been reported. porting bias)

No data on numbers with FRNS

\begin{tabular}{ll}
\hline Other bias $\quad$ Unclear risk $\quad$ Insufficient information to assess whether an important risk of bias exists \\
\hline
\end{tabular}

\section{Leisti 1978}

\begin{tabular}{ll}
\hline Methods & Study design: cross-over RCT \\
& - Time frame: not reported \\
\hline Participants & Follow-up: 2.4 years \\
\hline & - Country: Finland \\
- Setting: renal clinic & Inclusion criteria: children with relapsing SSNS and subnormal response to 2 hour ACTH test 1 to 12 \\
& - days after completing prednisone \\
& - Age range: 4.7 to 14.6 years \\
- Sex (M/F): $8 / 5$ \\
- Exclusion criteria: not reported
\end{tabular}

Treatment

- $15 \mathrm{mg}$ cortisol/d in $\geq 30 \mathrm{~kg}$ and $7.5 \mathrm{mg} / \mathrm{d}$ in $<30 \mathrm{~kg}$ for 6 months or till relapse

- Treated for 6 months or till relapse. After next relapse treated and post steroid adrenal suppression confirmed, patient given alternate therapy

- Dose of either medication doubled for 3 days when proteinuria or infection developed

Group 1

- Cortisol then placebo

Group 2

- Placebo then cortisol

\begin{tabular}{ll}
\hline Outcomes & Number with relapse during cortisol or placebo at 3 months and 6 months \\
\hline Notes & Data for 2 periods combined \\
& - Definitions \\
& $*$ Remission and relapse: ISKDC definitions \\
& - Further information requested from authors but not received \\
\hline
\end{tabular}

\section{Risk of bias}

\section{Bias}

Authors' judgement Support for judgement

$\begin{aligned} & \text { Random sequence genera- } \\ & \text { tion (selection bias) }\end{aligned}$
Unclear risk $\quad$ "allotted". No other information

tion (selection bias)

$\begin{aligned} & \text { Allocation concealment } \\ & \text { (selection bias) }\end{aligned} \quad$ Unclear risk Randomisation stated but no information on allocation concealment provided


Leisti 1978 (Continued)

Blinding of participants Low risk All participants and personnel blinded. Tablets were of identical taste and apand personnel (perforpearance

mance bias)

All outcomes

\begin{tabular}{lll}
\hline $\begin{array}{l}\text { Blinding of outcome as- } \\
\text { sessment (detection bias) } \\
\text { All outcomes }\end{array}$ & Low risk & All participants and personnel blinded \\
\hline $\begin{array}{l}\text { Incomplete outcome data } \\
\text { (attrition bias) } \\
\text { All outcomes }\end{array}$ & Low risk & All participants completed study \\
\hline $\begin{array}{l}\text { Selective reporting (re- } \\
\text { porting bias) }\end{array}$ & High risk & Not all review's pre-specified outcomes have been reported. \\
\hline Other bias & Low risk & No data on adverse events \\
\hline
\end{tabular}

Li 1994

$\begin{array}{ll}\text { Methods } & \text { Study design: parallel RCT } \\ \text { - Time frame: } 1990 \text { to December } 1992 \\ \text { - Follow-up period: unclear; at least } 6 \text { months }\end{array}$

\begin{tabular}{ll}
\hline Participants & Country: China \\
- Setting: university hospital \\
- Inclusion criteria: SSNS \\
- Number: treatment group 1 (19); treatment group $2(25)$ \\
- Mean age \pm SD (years): treatment group 1 (7.21 \pm 3.52$)$; treatment group $2(7.54 \pm 4.24)$ \\
- Sex (M/F): treatment group 1 (14/5); treatment group $2(18 / 7)$ \\
- Exclusion criteria: not reported
\end{tabular}

Interventions

Treatment group 1 (single dose)

- Prednisone $2 \mathrm{mg} / \mathrm{kg} / \mathrm{d}$ as single morning dose for 4 weeks; prednisone $2 \mathrm{mg} / \mathrm{kg}$ on alternate days for 5 weeks then gradually reduced till 6 months

Treatment group 2 (divided dose)

- Prednisone $2 \mathrm{mg} / \mathrm{kg} / \mathrm{d}$ given as three divided doses for 4 weeks; prednisone $2 \mathrm{mg} / \mathrm{kg}$ on alternate days for 5 weeks then gradually reduced till 6 months

\begin{tabular}{ll}
\hline Outcomes & - Time to remission \\
& - Toxicities \\
\hline \multirow{2}{*}{ Notes } & Exclusions post randomisation but pre-intervention: unclear \\
& - Stop or end point/s: not reported \\
& Additional data requested from authors: yes \\
\hline
\end{tabular}

\section{Risk of bias}

\section{Bias}

\section{Authors' judgement Support for judgement}


Li 1994 (Continued)

Random sequence genera- High risk Patients allocated by alternation
tion (selection bias)

Allocation concealment High risk Patients allocated by alternation
(selection bias)

\begin{tabular}{|c|c|c|}
\hline $\begin{array}{l}\text { Blinding of participants } \\
\text { and personnel (perfor- } \\
\text { mance bias) } \\
\text { All outcomes }\end{array}$ & High risk & $\begin{array}{l}\text { Blinding not reported and the outcome is likely to be influenced by lack of } \\
\text { blinding }\end{array}$ \\
\hline
\end{tabular}

\begin{tabular}{lll}
\hline Blinding of outcome as- & High risk & Blinding of outcome assessment not reported and outcome measurement \\
sessment (detection bias) & likely to be influenced by lack of blinding \\
All outcomes &
\end{tabular}

All outcomes

Incomplete outcome data Unclear risk Insufficient data to permit judgement
(attrition bias)

All outcomes

\begin{tabular}{lll}
\hline $\begin{array}{l}\text { Selective reporting (re- } \\
\text { porting bias) }\end{array}$ & High risk & Not all review's pre-specified outcomes have been reported. \\
& No data on frequent relapses \\
\hline Other bias & Unclear risk & Insufficient information to assess whether an important risk of bias exists \\
\hline
\end{tabular}

Liern 2008

\begin{tabular}{|c|c|}
\hline Methods & $\begin{array}{l}\text { - Study design: cross-over RCT } \\
\text { - Time frame: not reported } \\
\text { - Follow-up period: not reported }\end{array}$ \\
\hline Participants & $\begin{array}{l}\text { - Country: Argentina } \\
\text { - Setting: teaching hospital } \\
\text { - Inclusion criteria: children with SSNS enrolled after first relapse } \\
\text { - Number: } 11 \\
\text { - Mean age (range): } 48 \text { months ( } 16 \text { to } 52 \text { ) } \\
\text { - Sex (M/F): not reported } \\
\text { - Exclusion criteria: not reported }\end{array}$ \\
\hline Interventions & $\begin{array}{l}\text { Treatment group } 1 \\
\text { - Methylprednisolone: } 48 \mathrm{mg} / \mathrm{m}^{2} / \mathrm{d} \text { for } 6 \text { weeks (maximum dose not reported), followed by } 2 / 3 \text { of dose } \\
\text { on alternate days for } 6 \text { weeks } \\
\text { Treatment group } 2 \\
\text { - Deflazacort: } 72 \mathrm{mg} / \mathrm{m}^{2} / \mathrm{d} \text { for } 6 \text { weeks (maximum dose } 90 \mathrm{mg} \text { ), followed by } 2 / 3 \text { of dose on alternate } \\
\text { days for } 6 \text { weeks }\end{array}$ \\
\hline Outcomes & $\begin{array}{l}\text { - Mean time to remission } \\
\text { - Mean time to relapse } \\
\text { - Total IgG and its subclasses } \\
\text { - Adverse effects }\end{array}$ \\
\hline
\end{tabular}


Liern 2008 (Continued)
Notes
- Additional data requested from authors and received

\section{Risk of bias}

\begin{tabular}{|c|c|c|}
\hline Bias & Authors' judgement & Support for judgement \\
\hline $\begin{array}{l}\text { Random sequence genera- } \\
\text { tion (selection bias) }\end{array}$ & Low risk & Randomised by computer generated table (information received from author) \\
\hline $\begin{array}{l}\text { Allocation concealment } \\
\text { (selection bias) }\end{array}$ & Low risk & Central allocation \\
\hline $\begin{array}{l}\text { Blinding of participants } \\
\text { and personnel (perfor- } \\
\text { mance bias) } \\
\text { All outcomes }\end{array}$ & Low risk & Double blind to patients and medical caregivers \\
\hline $\begin{array}{l}\text { Blinding of outcome as- } \\
\text { sessment (detection bias) } \\
\text { All outcomes }\end{array}$ & Low risk & Double blind to patients and medical caregivers \\
\hline $\begin{array}{l}\text { Incomplete outcome data } \\
\text { (attrition bias) } \\
\text { All outcomes }\end{array}$ & Unclear risk & Unclear if all patients completed both arms of the study \\
\hline $\begin{array}{l}\text { Selective reporting (re- } \\
\text { porting bias) }\end{array}$ & High risk & $\begin{array}{l}\text { Not all review's pre-specified outcomes have been reported. } \\
\text { No data on relapse, frequent relapses and minimal data on adverse effects }\end{array}$ \\
\hline Other bias & Unclear risk & No information provided \\
\hline
\end{tabular}

Mattoo 2000

\begin{tabular}{ll}
\hline Methods & - Study design: parallel RCT \\
& - Time frame: not reported \\
& Follow-up period: 2 years
\end{tabular}

$\begin{array}{ll}\text { Participants } & \text { Country: Saudi Arabia } \\ \text { - Setting: university renal clinic } \\ \text { - Inclusion criteria: children with relapsing SSNS receiving prednisone } 0.5 \mathrm{mg} / \mathrm{kg} \text { on alternate days for } \\ \text { frequent relapses or following CPA } \\ \text { - Number: treatment group } 1(18) \text {; treatment group } 2(18) \\ \text { - Mean age } \pm \text { SD (years): treatment group } 1(7.2 \pm 3.3) \text {; treatment group } 2(6.8 \pm 3.6) \\ \text { - Sex (M/F): treatment group } 1 \text { (10/8); treatment group } 2(12 / 6) \\ \text { - Exclusion criteria: children who were not compliant or lost to follow-up were excluded from the analy- } \\ \text { sis }\end{array}$

Interventions

Treatment group 1

- Prednisone: daily $(0.5 \mathrm{mg} / \mathrm{kg})$ for 5 days during URTI

Treatment group 2

- Prednisone: $0.5 \mathrm{mg} / \mathrm{kg}$ on alternate days continued during URTI 
Mattoo 2000 (Continued)

\begin{tabular}{ll} 
Outcomes & Mean relapse rate/patient during 2 year follow-up \\
\hline Notes & $\bullet \begin{array}{l}\text { Definitions } \\
*\end{array}$ \\
& Relapse and remission: ISKDC
\end{tabular}

\section{Risk of bias}

Bias Authors' judgement Support for judgement

Random sequence genera- High risk Data received from authors, alternate patients allocated to groups tion (selection bias)

Allocation concealment High risk
(selection bias)

\begin{tabular}{lll}
\hline Blinding of participants & High risk & $\begin{array}{l}\text { Blinding not reported and the outcome is likely to be influenced by lack of } \\
\text { blinding }\end{array}$
\end{tabular}
mance bias)

All outcomes

\begin{tabular}{lll}
\hline $\begin{array}{l}\text { Blinding of outcome as- } \\
\text { sessment (detection bias) }\end{array}$ & High risk & $\begin{array}{l}\text { Blinding of outcome assessment not reported and outcome measurement } \\
\text { likely to be influenced by lack of blinding }\end{array}$ \\
All outcomes &
\end{tabular}

\begin{tabular}{lll}
\hline $\begin{array}{l}\text { Incomplete outcome data } \\
\text { (attrition bias) } \\
\text { All outcomes }\end{array}$ & Low risk & Each patient was followed for a period of two years \\
\hline $\begin{array}{l}\text { Selective reporting (re- } \\
\text { porting bias) }\end{array}$ & High risk & Not all review's pre-specified outcomes have been reported. \\
\hline Other bias & Unclear risk & No data on adverse events. Only steroid dependent patients included. \\
\hline
\end{tabular}

\section{Mishra 2012}

\begin{tabular}{|c|c|}
\hline Methods & $\begin{array}{l}\text { - Study design: parallel RCT } \\
\text { - Time frame: July } 2007 \text { to June } 2009 \\
\text { - Follow-up period: } 12 \text { months }\end{array}$ \\
\hline Participants & $\begin{array}{l}\text { - Country: India } \\
\text { - Setting: university teaching hospital } \\
\text { - Inclusion criteria: children with first episode of SSNS, aged } 1-10 \text { years. no systemic disease } \\
\text { - Number (analysed/randomised): treatment group } 1(40 / 37) \text {; treatment group } 2(40 / 37) \\
\text { - Mean age } \pm \mathrm{SD} \text { (years): treatment group } 1(4.4 \pm 3.0) \text {; treatment group } 2(5.3 \pm 3.1) \\
\text { - Sex (M/F): treatment group } 1(25 / 12) \text {; treatment group } 2(27 / 10) \\
\text { - Exclusion criteria: < 1year and }>10 \text { years; persistent hypertension }(>95 \text { th percentile for age, gender } \\
\text { on } 3 \text { occasions); gross haematuria; } \mathrm{CrCl}<80 \mathrm{~mL} / \mathrm{min} / 1.73 \mathrm{~m} 2 \text {; azotaemia; failure to achieve remission } \\
\text { by end of } 4 \text { weeks prednisone }\end{array}$ \\
\hline
\end{tabular}

Interventions

Treatment group 1 (prolonged treatment)

- Prednisolone: $2 \mathrm{mg} / \mathrm{kg}$ day for 6 weeks followed by $1.5 \mathrm{mg} / \mathrm{kg}$ on alternate days for 6 weeks, $1 \mathrm{mg} / \mathrm{kg}$ for 4 weeks, $0.5 \mathrm{mg} / \mathrm{kg}$ on alternate days for 4 weeks

- Total duration: 20 weeks 
Mishra 2012 (Continued)

- Calculated total dose: $3990 \mathrm{mg} / \mathrm{m}^{2}$

Treatment group 2 (standard treatment)

- Prednisone: $2 \mathrm{mg} / \mathrm{kg} / \mathrm{d}$ for 6 weeks, followed by $1.5 \mathrm{mg} / \mathrm{kg}$ on alternate days for 6 weeks

- Total duration: 12 weeks

- Calculated total dose: $3360 \mathrm{mg} / \mathrm{m}^{2}$

\begin{tabular}{ll}
\hline Outcomes & Mean relapse rate/patient during 2 year follow-up \\
- Number with frequently relapsing nephrotic syndrome & Adverse effects \\
\hline Notes & Definitions \\
& $*$ Relapse and remission: ISKDC \\
& - Children who did not complete treatment or were not followed for 12 months after treatment com- \\
& pletion were excluded from the study \\
- Additional data requested from authors and received
\end{tabular}

\section{Risk of bias}

Bias Authors' judgement Support for judgement

Random sequence genera- Low risk Computer generated

tion (selection bias)

Allocation concealment $\quad$ Unclear risk
(selection bias)

\begin{tabular}{|c|c|c|}
\hline $\begin{array}{l}\text { Blinding of participants } \\
\text { and personnel (perfor- } \\
\text { mance bias) }\end{array}$ & High risk & $\begin{array}{l}\text { Blinding not reported and the outcome is likely to be influenced by lack of } \\
\text { blinding }\end{array}$ \\
\hline
\end{tabular}

mance bias)

All outcomes

\begin{tabular}{|c|c|c|}
\hline $\begin{array}{l}\text { Blinding of outcome as- } \\
\text { sessment (detection bias) } \\
\text { All outcomes }\end{array}$ & High risk & $\begin{array}{l}\text { Blinding of outcome assessn } \\
\text { likely to be influenced by lac }\end{array}$ \\
\hline $\begin{array}{l}\text { Incomplete outcome data } \\
\text { (attrition bias) } \\
\text { All outcomes }\end{array}$ & Low risk & $5 / 80,6.3 \%$ lost to follow-up \\
\hline
\end{tabular}

\begin{tabular}{lll}
\hline $\begin{array}{l}\text { Selective reporting (re- } \\
\text { porting bias) }\end{array}$ & Unclear risk & $\begin{array}{l}\text { Did not reported on all of review's pre-specified outcomes } \\
\text { The number of patients with at least one relapse is unclear }\end{array}$ \\
\hline Other bias & Unclear risk & Insufficient information to assess whether an important risk of bias exists \\
\hline
\end{tabular}

\section{Mocan 1999}

\begin{tabular}{ll}
\hline Methods & - Study design: parallel RCT \\
& - Time frame: March 1990 to April 1996 \\
& - Follow-up period: 38 to 42 months \\
\hline Participants & - Country: Turkey
\end{tabular}


Mocan 1999 (Continued)

- Setting: single centre; university teaching hospital

- Inclusion criteria: Initial episode of SSNS

- Number: treatment group 1 (8); treatment group 2 (7)

- Mean age $\pm \mathrm{SE}$ (years): treatment group 1 (3.6 \pm 2.2$)$; treatment group $2(4.0 \pm 1.7)$

- Sex (M/F): treatment group 1 (7/1); treatment group $2(5 / 2)$

- Exclusion criteria: Not reported

\begin{tabular}{ll}
\hline Interventions & Treatment group 1 (high dose group) \\
- Methylprednisolone: $30 \mathrm{mg} / \mathrm{kg}$ for 3 days; $20 \mathrm{mg} / \mathrm{kg}$ for four days; $10 \mathrm{mg} / \mathrm{kg}$ for one week \\
- Total duration: 14 days \\
Treatment group 2 (standard therapy) \\
- Prednisolone: $60 \mathrm{mg} / \mathrm{m}^{2}$ for 4 weeks, followed by $45,30,20,10$ and $5 \mathrm{mg} / \mathrm{m}^{2}$ on alternate days for a \\
- further 5 months \\
- Total duration: $6 \mathrm{months}$ \\
\hline - Time to remission \\
- Time to first relapse \\
- Mean relapse rate during study \\
- Adverse effects \\
\hline Notes
\end{tabular}

\section{Risk of bias}

\begin{tabular}{|c|c|c|}
\hline Bias & Authors' judgement & Support for judgement \\
\hline $\begin{array}{l}\text { Random sequence genera- } \\
\text { tion (selection bias) }\end{array}$ & High risk & "Children arbitrarily randomised into two groups" \\
\hline $\begin{array}{l}\text { Allocation concealment } \\
\text { (selection bias) }\end{array}$ & High risk & "Children arbitrarily randomised into two groups" \\
\hline $\begin{array}{l}\text { Blinding of participants } \\
\text { and personnel (perfor- } \\
\text { mance bias) } \\
\text { All outcomes }\end{array}$ & High risk & $\begin{array}{l}\text { Blinding not reported and the outcome is likely to be influenced by lack of } \\
\text { blinding }\end{array}$ \\
\hline $\begin{array}{l}\text { Blinding of outcome as- } \\
\text { sessment (detection bias) } \\
\text { All outcomes }\end{array}$ & High risk & $\begin{array}{l}\text { Blinding of outcome assessment not reported and outcome measurement } \\
\text { likely to be influenced by lack of blinding }\end{array}$ \\
\hline $\begin{array}{l}\text { Incomplete outcome data } \\
\text { (attrition bias) } \\
\text { All outcomes }\end{array}$ & High risk & $\begin{array}{l}6 / 21 \text { excluded; } 4 / 21 \text { (21\%) lost to follow-up and this could influence results; } \\
2 / 21 \text { SRNS }\end{array}$ \\
\hline $\begin{array}{l}\text { Selective reporting (re- } \\
\text { porting bias) }\end{array}$ & High risk & Reported on adverse events, relapse rate but not number with FRNS \\
\hline Other bias & Unclear risk & Insufficient information to assess whether an important risk of bias exists \\
\hline
\end{tabular}


Norero 1996

\begin{tabular}{|c|c|}
\hline Methods & $\begin{array}{l}\text { - Study design: parallel RCT } \\
\text { - Time frame: not reported } \\
\text { - Duration of follow-up: } 18 \text { months }\end{array}$ \\
\hline Participants & $\begin{array}{l}\text { - Country: Chile } \\
\text { - Setting: multicentre (11), renal clinics } \\
\text { - Inclusion criteria: children with initial episode SSNS } \\
\text { - Age: } 6 \text { months to } 15 \text { years } \\
\text { - Number: treatment group } 1(29) \text {; treatment group } 2(27) \\
\text { - Mean age, range (months): treatment group } 1(25.5,11 \text { to } 156) \text {; treatment group } 2(26,16 \text { to } 144) \\
\text { - Sex (M/F): not reported } \\
\text { - Exclusion criteria: secondary INS; initially or became SRNS or SDNS; deviations from therapeutic } \\
\text { scheme; release } 3 \text { months before end of therapy; biopsy showing a different histology to minimal } \\
\text { changes }\end{array}$ \\
\hline Interventions & $\begin{array}{l}\text { Treatment group } 1 \text { ( } 3 \text { months) } \\
\text { - Prednisolone: } 6 \text { weeks each of } 60 \mathrm{mg} / \mathrm{m}^{2} / \mathrm{d} \text { and } 40 \mathrm{mg} / \mathrm{m}^{2} \text { on alternate days } \\
\text { - Total duration: } 12 \text { weeks } \\
\text { - Total dose: } 3600 \mathrm{mg} / \mathrm{m}^{2} \\
\text { Treatment group } 2 \text { ( } 2 \text { months) } \\
\text { - Prednisolone: } 4 \text { weeks each of } 60 \mathrm{mg} / \mathrm{m}^{2} / \mathrm{d} \text { and } 40 \mathrm{mg} / \mathrm{m}^{2} \text { on alternate days } \\
\text { - Total duration: } 8 \text { weeks } \\
\text { - Total dose: } 2400 \mathrm{mg} / \mathrm{m}^{2}\end{array}$ \\
\hline Outcomes & $\begin{array}{l}\text { - Number with relapse by } 12 \text { months and } 18 \text { months } \\
\text { - Mean relapse rate/patient in } 18 \text { months } \\
\text { - Number with frequent relapses } \\
\text { - Adverse effects }\end{array}$ \\
\hline Notes & $\begin{array}{l}\text { - Children with SDNS (relapse on reducing dose of steroids) were excluded } \\
\text { - Renal biopsy showing minimal change disease required for study entry } \\
\text { - Definitions: } \\
\text { * FRNS: } 2+\text { relapses in } 6 \text { months or } 3+\text { in } 1 \text { year } \\
\text { * Relapse: urinary protein } 100 \mathrm{mg} / \mathrm{kg} / \mathrm{d} \text { or } 40 \mathrm{mg} / \mathrm{m}^{2} / \mathrm{h} \text { or urine protein/creatinine ratio }>1 \text { or } 3+\text { on } \\
\text { dipstick for }>3 \text { days } \\
\text { * Remission: urine protein }<150 \mathrm{mg} / \mathrm{d} \text { for } 3 \text { consecutive days } \\
\text { - Time to } 1 \text { st relapse: not reported }\end{array}$ \\
\hline
\end{tabular}

\section{Risk of bias}

\begin{tabular}{lll}
\hline Bias & Authors' judgement & Support for judgement \\
\hline $\begin{array}{l}\text { Random sequence genera- } \\
\text { tion (selection bias) }\end{array}$ & Unclear risk & Not reported \\
\hline $\begin{array}{l}\text { Allocation concealment } \\
\text { (selection bias) }\end{array}$ & High risk & Patients allocated by odd or even numbers \\
\hline $\begin{array}{l}\text { Blinding of participants } \\
\text { and personnel (perfor- } \\
\text { mance bias) } \\
\text { All outcomes }\end{array}$ & High risk & $\begin{array}{l}\text { Blinding not reported and the outcome is likely to be influenced by lack of } \\
\text { blinding }\end{array}$ \\
\hline \hline
\end{tabular}


Norero 1996 (Continued)

Blinding of outcome as- High risk Blinding of outcome assessment not reported and outcome measurement sessment (detection bias) likely to be influenced by lack of blinding

All outcomes

\begin{tabular}{|c|c|c|}
\hline $\begin{array}{l}\text { Incomplete outcome data } \\
\text { (attrition bias) } \\
\text { All outcomes }\end{array}$ & High risk & $\begin{array}{l}\text { Number excluded or lost to follow-up: } 56 / 96 \text { completed follow-up. Of } 40 \text { ex- } \\
\text { cluded patients, } 19 \text { had SRNS. Remaining } 21 \text { excluded inappropriately: SDNS } \\
\text { (5); deviation from protocol (3); duration of follow-up insufficient (11); loss to } \\
\text { follow-up (2) }\end{array}$ \\
\hline
\end{tabular}

\begin{tabular}{lll}
\hline $\begin{array}{l}\text { Selective reporting (re- } \\
\text { porting bias) }\end{array}$ & Low risk & Reported on all of review's pre-specified outcomes \\
\hline Other bias & Low risk & $\begin{array}{l}\text { Grant No } 1940506 \text { from FONDECYT (National Scientific and Technology Foun- } \\
\text { dation) }\end{array}$ \\
\hline
\end{tabular}

\section{Pecoraro 2003}

\begin{tabular}{ll} 
Methods & - Study design: parallel RCT \\
& - Time frame: not reported \\
& - Follow-up: 12 months \\
\hline Participants & - Country: Italy \\
- Setting: renal clinic \\
- Inclusion criteria: children with initial episode of SSNS \\
- Mean age \pm SD (years): not reported \\
- Sex (M/F): not reported \\
- Exclusion criteria: not reported
\end{tabular}

\section{Treatment group 1}

- Prednisone: $2 \mathrm{mg} / \mathrm{kg} / \mathrm{d}$ for 6 weeks; $2 \mathrm{mg} / \mathrm{kg}$ on alternate days for 6 weeks, reduced by $0.25 \mathrm{mg} / 2$ weeks

- Total duration: 26 weeks

- Total calculated dose: $5235 \mathrm{mg} / \mathrm{m}^{2}$

Treatment group 2

- IV methylprednisolone: $20 \mathrm{mg} / \mathrm{kg} / \mathrm{d}$ for 3 days; $1 \mathrm{mg} / \mathrm{kg} / \mathrm{d}$ for 6 weeks; $1 \mathrm{mg} / \mathrm{kg}$ on alternate days for 6 weeks; reduced by $0.25 \mathrm{mg} / 2$ to 4 weeks

- Total duration: 26 weeks

Treatment group 3

- Prednisone: $2 \mathrm{mg} / \mathrm{kg} / \mathrm{d}$ for 4 weeks; $2 \mathrm{mg} / \mathrm{kg}$ on alternate days for 4 weeks; decreased by $0.25 \mathrm{mg} / \mathrm{week}$

- Total duration: 12 weeks

- Total calculated dose: $2362 \mathrm{mg} / \mathrm{m}^{2}$

\begin{tabular}{ll}
\hline Outcomes & - Number with relapse at 1 year and 2 years \\
& - Adverse effects \\
& - Cumulative steroid dose \\
\hline Notes & - No definitions provided \\
& Abstracts only \\
\hline
\end{tabular}


Pecoraro 2003 (Continued)

Risk of bias

\begin{tabular}{|c|c|c|}
\hline Bias & Authors' judgement & Support for judgement \\
\hline $\begin{array}{l}\text { Random sequence genera- } \\
\text { tion (selection bias) }\end{array}$ & High risk & Information from authors suggests "alternation" was used \\
\hline $\begin{array}{l}\text { Allocation concealment } \\
\text { (selection bias) }\end{array}$ & High risk & 'Alternation" was used \\
\hline $\begin{array}{l}\text { Blinding of participants } \\
\text { and personnel (perfor- } \\
\text { mance bias) } \\
\text { All outcomes }\end{array}$ & High risk & $\begin{array}{l}\text { Blinding not reported and the outcome is likely to be influenced by lack of } \\
\text { blinding }\end{array}$ \\
\hline $\begin{array}{l}\text { Blinding of outcome as- } \\
\text { sessment (detection bias) } \\
\text { All outcomes }\end{array}$ & High risk & $\begin{array}{l}\text { Blinding of outcome assessment not reported and outcome measurement } \\
\text { likely to be influenced by lack of blinding }\end{array}$ \\
\hline $\begin{array}{l}\text { Incomplete outcome data } \\
\text { (attrition bias) } \\
\text { All outcomes }\end{array}$ & Unclear risk & $\begin{array}{l}\text { Said that all patients completed follow-up but unclear whether any patients } \\
\text { had been excluded }\end{array}$ \\
\hline $\begin{array}{l}\text { Selective reporting (re- } \\
\text { porting bias) }\end{array}$ & High risk & $\begin{array}{l}\text { Not all review's pre-specified outcomes have been reported. } \\
\text { No data on frequent relapses }\end{array}$ \\
\hline Other bias & High risk & Educational grant from Fresenius \\
\hline
\end{tabular}

Satomura 2001

\begin{tabular}{ll}
\hline Methods & - Study design: quasi RCT \\
& - Study duration: not reported \\
& - Duration of follow-up: I year \\
\hline Participants & - Country: Japan \\
- Setting: multicentre renal clinics \\
- Number: treatment group 1 (37); treatment group 2 (36) \\
- Mean age \pm SD (years): not reported \\
- Sex (M/F): not reported \\
- Exclusion criteria: not reported
\end{tabular}

Interventions

Treatment group 1 (high dose)

- Prednisolone: $60 \mathrm{mg} / \mathrm{m}^{2} / \mathrm{d}$ for 4 weeks; $40 \mathrm{mg} / \mathrm{m}^{2}$ on alternate days for 4 weeks

- Total duration: 8 weeks

Treatment group 2 (low dose)

- Prednisolone: $40 \mathrm{mg} / \mathrm{m}^{2} / \mathrm{d}$ for 4 weeks; $40 \mathrm{mg} / \mathrm{kg}$ on alternate days for 8 weeks

- Total duration: 12 weeks

\section{Outcomes}

- Number with relapse at 12 months 
Satomura 2001 (Continued)

- Time to relapse

$\begin{array}{ll}\text { Notes } & \text { Abstract only } \\ & \text { - No definitions provided }\end{array}$

\section{Risk of bias}

\begin{tabular}{|c|c|c|}
\hline Bias & Authors' judgement & Support for judgement \\
\hline $\begin{array}{l}\text { Random sequence genera- } \\
\text { tion (selection bias) }\end{array}$ & High risk & Patients assigned "alternately" \\
\hline $\begin{array}{l}\text { Allocation concealment } \\
\text { (selection bias) }\end{array}$ & High risk & "Alternation" used \\
\hline $\begin{array}{l}\text { Blinding of participants } \\
\text { and personnel (perfor- } \\
\text { mance bias) } \\
\text { All outcomes }\end{array}$ & High risk & $\begin{array}{l}\text { Blinding not reported and the outcome is likely to be influenced by lack of } \\
\text { blinding }\end{array}$ \\
\hline $\begin{array}{l}\text { Blinding of outcome as- } \\
\text { sessment (detection bias) } \\
\text { All outcomes }\end{array}$ & High risk & $\begin{array}{l}\text { Blinding of outcome assessment not reported and outcome measurement } \\
\text { likely to be influenced by lack of blinding }\end{array}$ \\
\hline $\begin{array}{l}\text { Incomplete outcome data } \\
\text { (attrition bias) } \\
\text { All outcomes }\end{array}$ & Unclear risk & Insufficient data to permit judgement \\
\hline $\begin{array}{l}\text { Selective reporting (re- } \\
\text { porting bias) }\end{array}$ & Unclear risk & Insufficient data to permit judgement \\
\hline Other bias & Unclear risk & Insufficient data to permit judgement \\
\hline
\end{tabular}

\section{Sharma 2000}

\begin{tabular}{ll}
\hline Methods & Study design: parallel RCT \\
& - Time frame: not reported \\
\hline Participants & Duration of follow-up: at least 1 year \\
\hline & - Country: India \\
- Setting: university renal clinic & Inclusion criteria: initial episode of SSNS. 156 enrolled in study and 140 evaluated \\
- Number: treatment group 1 (70); treatment group 2 (70) & Mean age \pm SD: $8.9 \pm 6.8$ years \\
- Sex (M/F): not reported & Exclusion criteria: not reported \\
Treatment group $1(6 \mathrm{months})$ \\
- Prednisolone: $60 \mathrm{mg} / \mathrm{m}^{2} / \mathrm{d}$ for 6 weeks; $40 \mathrm{mg} / \mathrm{m}^{2}$ on alternate days for 6 weeks; taper by $10 \mathrm{mg} / \mathrm{m}^{2}$ \\
Interventions \\
- Total duration: $6 \mathrm{months}$ \\
- Total dose: $4200 \mathrm{mg} / \mathrm{m}^{2}$ \\
Treatment group $2(3 \mathrm{months})$
\end{tabular}


- Prednisolone: $60 \mathrm{mg} / \mathrm{m}^{2} / \mathrm{d}$ for 6 weeks; $40 \mathrm{mg} / \mathrm{m}^{2}$ on alternate days for 6 weeks; abrupt cessation at 12 weeks without tapering

- Total duration: 3 months

- Total calculated dose: $3360 \mathrm{mg} / \mathrm{m}^{2}$

\begin{tabular}{ll}
\hline Outcomes & Number with relapse by 6 and 12 months \\
- & Mean relapse rate \\
- & Cumber with frequently relapsing nephrotic syndrome \\
- Adverse events & \\
\hline Notes & $*$ Definitions \\
& $*$ Remission and relapse: ISKDC $2+$ in 6 months or $6+$ in 18 months \\
& $*$ SDNS: APN definition \\
\hline
\end{tabular}

\section{Risk of bias}

\begin{tabular}{|c|c|c|}
\hline Bias & Authors' judgement & Support for judgement \\
\hline $\begin{array}{l}\text { Random sequence genera- } \\
\text { tion (selection bias) }\end{array}$ & Low risk & $\begin{array}{l}\text { 'table of random numbers". Randomisation at } 12 \text { weeks after the beginning of } \\
\text { initial therapy. Information provided by authors }\end{array}$ \\
\hline $\begin{array}{l}\text { Allocation concealment } \\
\text { (selection bias) }\end{array}$ & Unclear risk & 'table of random numbers' \\
\hline $\begin{array}{l}\text { Blinding of participants } \\
\text { and personnel (perfor- } \\
\text { mance bias) } \\
\text { All outcomes }\end{array}$ & High risk & Not blinded and outcome is likely to be influenced by lack of blinding \\
\hline $\begin{array}{l}\text { Blinding of outcome as- } \\
\text { sessment (detection bias) } \\
\text { All outcomes }\end{array}$ & High risk & Not blinded and outcome is likely to be influenced by lack of blinding \\
\hline $\begin{array}{l}\text { Incomplete outcome data } \\
\text { (attrition bias) } \\
\text { All outcomes }\end{array}$ & High risk & $\begin{array}{l}\text { 16/156 excluded (10.3\%); } 160 \text { consecutive patients, } 4 \text { refused consent. Of } 156 \\
\text { entered, } 10 \text { were non-compliant and } 6 \text { lost to follow-up and their results were } \\
\text { excluded from analysis }\end{array}$ \\
\hline $\begin{array}{l}\text { Selective reporting (re- } \\
\text { porting bias) }\end{array}$ & Low risk & All the reviews pre-specified outcomes have been reported \\
\hline Other bias & Unclear risk & Non information provided \\
\hline
\end{tabular}

Sinha 2014

\begin{tabular}{ll}
\hline Methods & Study design: parallel RCT \\
& - Time frame: July 2010 to May 2012 \\
& - Follow-up: 1 year \\
\hline Participants & Country: India \\
& - Setting: multicentre $(5) ;$ academic centres \\
- Inclusion criteria: children aged 1 to 12 years with first episode of SSNS; 3 to $4+$ proteinuria or urinary \\
protein/creatinine $\geq 2 \mathrm{mg} / \mathrm{mg} ;$ albumin $<2.5 \mathrm{~g} / \mathrm{dL} ;$ oedema
\end{tabular}


Sinha 2014 (Continued)

- Number: treatment group 1 (92); treatment group 2 (89)

- Median age, IQR (months): treatment group 1 (44.2, 34.2 to 74.4 ); treatment group 2 (42.4, 30.0 to 70.5 )

- Sex (M/F): treatment group 1 (56/36); treatment group 2 (59/0)

- Exclusion criteria: eGFR $<60 \mathrm{~mL} / \mathrm{min} / 1.73 \mathrm{~m}^{2}$; known secondary cause (HSP, SLE, hepatitis B or haematuria); residence $>200 \mathrm{~km}$ away; previous steroid therapy

- Prednisolone $2 \mathrm{mg} / \mathrm{kg} / \mathrm{d}$ for 6 weeks, $1.5 \mathrm{mg} / \mathrm{kg} / \mathrm{d}$ then $1.5 \mathrm{mg} / \mathrm{kg}$ on alternate days for 6 weeks

- Actual total dose $2791.7 \pm 286.6 \mathrm{mg} / \mathrm{m}^{2}$

Treatment group 2 (6 months)

- $2 \mathrm{mg} / \mathrm{kg} / \mathrm{d}$ for 6 weeks, $1.5 \mathrm{mg} / \mathrm{kg}$ on alternate days for 6 weeks, $1 \mathrm{mg} / \mathrm{kg}, 0.75 \mathrm{mg} / \mathrm{kg}$, and $0.5 \mathrm{mg} / \mathrm{kg}$ on alternate days for 4 weeks each

- Actual total dose $3529.7 \pm 398.7 \mathrm{mg} / \mathrm{m}^{2}$

Co-interventions

- Patients on long term steroids received daily supplements of calcium (250 to $500 \mathrm{mg}$ ) and vitamin D (200 to $400 \mathrm{U}$ )

- Hypertension was treated with amlodipine or enalapril

- Number of steroid sensitive relapses during 12 months of follow-up
- Proportion with FRNS at 12 and 24 months
- Cumulative steroid dose $\mathrm{mg} / \mathrm{m}^{2} / \mathrm{y}$ from randomisation to 12 and 24 months
- Need for steroid sparing therapies at 12 and 24 months
- Mean relapse rate at 12 and 24 months
- Frequency and type of serious adverse events

Notes

- Funded by Indian Council of Medical Research

- Definitions

* Relapse, remission, FRNS: ISKDC

\section{Risk of bias}

\begin{tabular}{lll}
\hline Bias & Authors' judgement & Support for judgement \\
\hline $\begin{array}{l}\text { Random sequence genera- } \\
\text { tion (selection bias) }\end{array}$ & Low risk & Computer generated. Randomly assigned 1:1 in permuted blocks of four \\
\hline $\begin{array}{l}\text { Allocation concealment } \\
\text { (selection bias) }\end{array}$ & Low risk & $\begin{array}{l}\text { "Procedures for randomisation and packing and distribution were conducted } \\
\text { at this centre by individuals, who were not involved in trial implementation" }\end{array}$ \\
\hline $\begin{array}{l}\text { Blinding of participants } \\
\text { and personnel (perfor- } \\
\text { mance bias) }\end{array}$ & Low risk & $\begin{array}{l}\text { "External pharmacy manufactured identical-appearing sugar coated tablets } \\
\text { of prednisolone and placebo, packaged in matching blister packs of 10 tablets } \\
\text { each" }\end{array}$ \\
\hline $\begin{array}{l}\text { Blinding of outcome as- } \\
\text { sessment (detection bias) } \\
\text { All outcomes }\end{array}$ & Low risk & $\begin{array}{l}\text { "Investigators, patients and outcome assessors were blinded to randomisa- } \\
\text { tion schedule. Masking was maintained during data analysis, following which } \\
\text { the randomisation code was broken" }\end{array}$ \\
\hline $\begin{array}{l}\text { Incomplete outcome data } \\
\text { (attrition bias) } \\
\begin{array}{l}\text { All outcomes } \\
\hline\end{array}\end{array}$ & Low risk & \begin{tabular}{l} 
6/181 (3\%) excluded (SRNS 1, loss to follow-up 5) \\
\hline
\end{tabular}
\end{tabular}


Sinha 2014 (Continued)

Selective reporting (re- Low risk $\quad$ All prespecified outcomes reported
porting bias)

Other bias Low risk Funded by Indian Council of Medical Research

Teeninga 2013

\begin{tabular}{ll}
\hline Methods & - Study design: parallel RCT \\
- Time frame: February 2005 to December 2009 \\
- Duration of study: up to 5 years. Minimum follow-up 18 months
\end{tabular}

Participants
- Country: The Netherlands, Belgium
- Inclusion criteria: children aged 9 months to 7 years with initial episode of SSNS
- Number: treatment group 1 (62); treatment group 2 (64)
- Median age, IQR (years): treatment group 1 (47, 3.2 to 6.2$)$; treatment group $2(3.8,3.2$ to 6.4$)$
- Sex (M/F): treatment group 1 (39/23); treatment group $2(47 / 27)$
- Exclusion criteria: secondary nephrotic syndrome. SRNS

Interventions

Treatment group 1 (3 months)

- Prednisolone: $60 \mathrm{mg} / \mathrm{m}^{2} / \mathrm{d}$ for 6 weeks; $40 \mathrm{mg} / \mathrm{m}^{2}$ on alternate days for 6 weeks; placebo on alternate days for 12 weeks

- Cumulative dose: $3360 \mathrm{mg} / \mathrm{m}^{2}$

- Total duration: 12 weeks

- Median duration of follow-up: 47 months (IQR 32 to 60 )

Treatment group 2 (6 months)

- Prednisolone: $60 \mathrm{mg} / \mathrm{m}^{2}$ daily for 10 days; $50 \mathrm{mg} / \mathrm{m}^{2}$ daily till 6 weeks; $40 \mathrm{mg} / \mathrm{m}^{2}$ on alternate days till end week $10 ; 30 \mathrm{mg} / \mathrm{m}^{2}$ till end week $14,10 \mathrm{mg} / \mathrm{m}^{2}$ on alternate days till end week 24

- Total duration: 24 weeks

- Cumulative dose 3320 to $3710 \mathrm{mg} / \mathrm{m}^{2}$

- Median duration of follow-up: 47 months (IQR 37 to 60 )

$\begin{array}{ll}\text { - Putcomes } & \text { Primary outcome event was FRNS } \\ \text { - Cumulative incidences of first relapse, steroid dependence } \\ \text { - Cumber of relapses per patient year } \\ \text { - Adverse events }\end{array}$


Teeninga 2013 (Continued)

Notes
- Definitions

* Nephrotic syndrome: $>200 \mathrm{mg}$ protein/mmol creatinine in urine and albumin $<25 \mathrm{~g} / \mathrm{L}$ in serum

* Remission: urinary protein excretion $<20 \mathrm{mg} / \mathrm{L}$ or negative/trace on dipstick analysis on 3 consecutive days

* Relapse: proteinuria $\geq 2+$ on dipstick analysis or $>200 \mathrm{mg}$ protein $/ \mathrm{mmol}$ creatinine for 3 consecutive days after previously achieved remission

* FRNS: "Strict" definition: a) 2 or more relapses in 6 months after completing initial therapy; b) 4 relapses within any 12 month period, including relapses during initial treatment

* FRNS: "Clinical" definition: Frequently relapsing NS based on clinically relevant decision that included additional treatment of prednisolone maintenance therapy ( $>3$ months) or other immunosuppressive agents

* SDNS: 2 or more consecutive relapses either during or within 2 weeks after cessation of prednisolone (APN definition)

\section{Risk of bias}

\begin{tabular}{|c|c|c|}
\hline Bias & Authors' judgement & Support for judgement \\
\hline $\begin{array}{l}\text { Random sequence genera- } \\
\text { tion (selection bias) }\end{array}$ & Low risk & Central pharmacy with a computer generated random number table \\
\hline $\begin{array}{l}\text { Allocation concealment } \\
\text { (selection bias) }\end{array}$ & Low risk & $\begin{array}{l}\text { Central pharmacy, controlled allocation concealment with a computer gen- } \\
\text { erated random number table. Provided prepackaged medications, with fixed } \\
\text { and blinded dose. }\end{array}$ \\
\hline $\begin{array}{l}\text { Blinding of participants } \\
\text { and personnel (perfor- } \\
\text { mance bias) } \\
\text { All outcomes }\end{array}$ & Low risk & $\begin{array}{l}\text { Participants, health care providers, data collectors and researchers were } \\
\text { blinded to group allocation. Identical tasteless capsules containing pred- } \\
\text { nisolone or placebo }\end{array}$ \\
\hline $\begin{array}{l}\text { Blinding of outcome as- } \\
\text { sessment (detection bias) } \\
\text { All outcomes }\end{array}$ & Low risk & $\begin{array}{l}\text { Participants, health care providers, data collectors and researchers were } \\
\text { blinded to group allocation. Randomisation code broken September } 2011 .\end{array}$ \\
\hline $\begin{array}{l}\text { Incomplete outcome data } \\
\text { (attrition bias) } \\
\text { All outcomes }\end{array}$ & Low risk & $\begin{array}{l}\text { All patients with consent and not SRNS were included and followed up (13 } \\
\text { withdrew consent, } 11 \text { steroid resistant). }\end{array}$ \\
\hline $\begin{array}{l}\text { Selective reporting (re- } \\
\text { porting bias) }\end{array}$ & Low risk & All the review's pre-specified outcomes have been reported \\
\hline Other bias & Low risk & $\begin{array}{l}\text { No disclosures. Trial registered Netherlands Trial Registry number } 255 \text {. Funded } \\
\text { by Dutch kidney Foundation Grant C03 and by Vrienden van het Sophia Foun- } \\
\text { dation }\end{array}$ \\
\hline
\end{tabular}

Ueda 1988

\begin{tabular}{ll}
\hline Methods & - Study design: parallel RCT \\
& - Time frame: not reported \\
& - Duration of follow-up: 1 year \\
\hline Participants & - Country: Japan. \\
- Setting: university renal clinic \\
- Inclusion criteria: children aged 12 weeks to 16 years with first episode SSNS; severe proteinuria, $\geq 40$ \\
\\
$\mathrm{mg} / \mathrm{h} / \mathrm{m}^{2} ;$ hypoalbuminaemia, $\leq 2.5 \mathrm{~g} / \mathrm{dL}$
\end{tabular}


Ueda 1988 (Continued)

- Number: treatment group 1 (17); treatment group 2 (29)

- Mean age \pm SD (years): treatment group 1 (5.6 \pm 3.2$)$; treatment group 2 (7.2 \pm 3.2$)$

- $\operatorname{Sex}(M / F)$ : treatment group 1 (10/7); treatment group 2 (23/6)

- Exclusion criteria: prior treatment with steroids or cytotoxic agents; evidence of underlying systemic illness; exposure to agents know to be associated with nephrotic syndrome

\begin{tabular}{ll}
\hline Interventions & Treatment group 1 (prolonged) \\
- & Prednisolone: $60 \mathrm{mg} / \mathrm{m}^{2} / \mathrm{d}$ for 4 weeks, $60 \mathrm{mg} / \mathrm{m}^{2}$ on alternate days for 4 weeks and taper by $10 \mathrm{mg} /$ \\
& $\mathrm{m}^{2} / \mathrm{mo}$ \\
- & Total duration: $7 \mathrm{months}$ \\
Treatment group 2 (standard) \\
- Prednisolone: $60 \mathrm{mg} / \mathrm{m}^{2} / \mathrm{d}$ for 4 weeks and $40 \mathrm{mg} / \mathrm{m}^{2}$ on $3 / 7$ days for 4 weeks \\
- Total duration: $2 \mathrm{months}$ \\
\hline - Number relapsing by $6 \mathrm{month}$ and $12 \mathrm{months}$ after completing daily and alternate-day prednisolone \\
- Relapse rate/patient/y \\
- FRNS \\
- Adverse effects \\
- Unequal numbers in groups \\
- Definitions \\
$*$ FRNS: any relapse occurring within 2 months after ceasing prednisone \\
$*$ Relapse: ISKDC \\
$*$ Remission: ISKDC
\end{tabular}

\section{Risk of bias}

Bias Authors' judgement Support for judgement

Random sequence genera- Unclear risk 'allocated randomly', insufficient information about the sequence generation tion (selection bias) process to permit judgement

\begin{tabular}{lll}
\hline $\begin{array}{l}\text { Allocation concealment } \\
\text { (selection bias) }\end{array}$ & Unclear risk & $\begin{array}{l}\text { Not mentioned, randomisation stated but no information on method used } \\
\text { available }\end{array}$ \\
\hline $\begin{array}{l}\text { Blinding of participants } \\
\text { and personnel (perfor- } \\
\text { mance bias) }\end{array}$ & High risk & Not blinded and outcome is likely to be influenced by lack of blinding \\
All outcomes &
\end{tabular}

$\begin{array}{lll}\text { Blinding of outcome as- } & \text { High risk } & \text { Not blinded and outcome is likely to be influenced by lack of blinding } \\ \text { sessment (detection bias) }\end{array}$
All outcomes

\begin{tabular}{|c|c|c|}
\hline $\begin{array}{l}\text { Incomplete outcome data } \\
\text { (attrition bias) } \\
\text { All outcomes }\end{array}$ & Unclear risk & $\begin{array}{l}\text { Unclear whether any patients, who were randomised, were not included in } \\
\text { analysis; complete } 1 \text { year follow-up }\end{array}$ \\
\hline
\end{tabular}

\begin{tabular}{lll}
\hline $\begin{array}{l}\text { Selective reporting (re- } \\
\text { porting bias) }\end{array}$ & Low risk & The pre-specified outcomes of the review have been reported \\
\hline Other bias & Low risk & Supported by a grant from the Ministry of Health and Welfare in Japan \\
\hline
\end{tabular}


Yoshikawa 1998

\begin{tabular}{|c|c|}
\hline Methods & $\begin{array}{l}\text { - Study design: parallel RCT } \\
\text { - Time frame: January } 1990 \text { to December } 1992 \\
\text { - Follow-up: } 2 \text { years }\end{array}$ \\
\hline Participants & $\begin{array}{l}\text { - } \text { Country: Japan } \\
\text { - Setting: multicentre renal clinics } \\
\text { - Inclusion criteria: children with first episode of SSNS } \\
\text { - Number (analysed/randomised): treatment group } 1(83 / 96) \text {; treatment group } 2 \text { (88/98) } \\
\text { - Mean age } \pm \text { SD (years): treatment group } 1(7.1 \pm 3.7) \text {; treatment group } 2(8.0 \pm 4.1) \\
\text { - Sex (M/F): not reported } \\
\text { - Exclusion criteria: } \text { not reported }\end{array}$ \\
\hline Interventions & $\begin{array}{l}\text { Treatment group } 1 \text { (prolonged) } \\
\text { - Prednisolone: } 2 \mathrm{mg} / \mathrm{kg} / \mathrm{d} \text { for } 4 \text { weeks, } 2 \mathrm{mg} / \mathrm{kg} \text { on alternate days for } 8 \text { weeks, } 1.5 \mathrm{mg} / \mathrm{kg} \text { on alternate } \\
\text { days for } 2 \text { weeks, } 1 \mathrm{mg} / \mathrm{kg} \text { on alternate days for } 2 \text { weeks, } 0.5 \mathrm{mg} / \mathrm{kg} \text { on alternate days for } 2 \text { weeks } \\
\text { - Total duration: } 18 \text { weeks } \\
\text { Treatment group } 2 \text { (standard) } \\
\text { - Prednisone: } 2 \mathrm{mg} / \mathrm{kg} / \mathrm{d} \text { for } 4 \text { weeks, } 1.3 \mathrm{mg} / \mathrm{kg} \text { on alternate day for } 4 \text { weeks } \\
\text { - Total duration: } 8 \text { weeks } \\
\text { Co-interventions } \\
\text { - Both groups given Chinese herb Sairei-to: }>40 \mathrm{~kg} 8.1 \mathrm{~g} / \mathrm{d} ; 20 \text { to } 40 \mathrm{~kg} 5.4 \mathrm{~g} / \mathrm{d} ;<20 \mathrm{~kg} 2.7 \mathrm{~g} / \mathrm{d}\end{array}$ \\
\hline Outcomes & $\begin{array}{l}\text { - Number relapsing by } 2 \text { years. } \\
\text { - Number of patients with FRNS }\end{array}$ \\
\hline Notes & $\begin{array}{l}\text { - Definitions } \\
* \text { Relapse, FRNS: ISKDC }\end{array}$ \\
\hline
\end{tabular}

\section{Risk of bias}

\begin{tabular}{|c|c|c|}
\hline Bias & Authors' judgement & Support for judgement \\
\hline $\begin{array}{l}\text { Random sequence genera- } \\
\text { tion (selection bias) }\end{array}$ & Low risk & 'randomly assigned, concealed envelopes' \\
\hline $\begin{array}{l}\text { Allocation concealment } \\
\text { (selection bias) }\end{array}$ & Low risk & 'randomly assigned, concealed envelopes' \\
\hline $\begin{array}{l}\text { Blinding of participants } \\
\text { and personnel (perfor- } \\
\text { mance bias) } \\
\text { All outcomes }\end{array}$ & High risk & Not blinded and outcome is likely to be influenced by lack of blinding \\
\hline $\begin{array}{l}\text { Blinding of outcome as- } \\
\text { sessment (detection bias) } \\
\text { All outcomes }\end{array}$ & High risk & Not blinded and outcome is likely to be influenced by lack of blinding \\
\hline $\begin{array}{l}\text { Incomplete outcome data } \\
\text { (attrition bias) } \\
\text { All outcomes }\end{array}$ & High risk & $25 / 196(13 \%)$ did not complete study \\
\hline
\end{tabular}


Yoshikawa 1998 (Continued)

\begin{tabular}{|c|c|c|}
\hline $\begin{array}{l}\text { Selective reporting (re- } \\
\text { porting bias) }\end{array}$ & High risk & $\begin{array}{l}\text { Not all the reviews, pre-specified outcomes were reported. No reports of ad- } \\
\text { verse effects of steroids }\end{array}$ \\
\hline
\end{tabular}

Other bias Unclear risk Insufficient data to permit judgment

Yoshikawa 2014

\begin{tabular}{ll}
\hline Methods & Study design: parallel RCT \\
- & Time frame: 6 September 2007 to 9 February 2013 \\
- & Follow-up: 2 years \\
\hline Participants & Country: Japan \\
- Setting: multicentre $(90$ hospitals) \\
- Inclusion criteria: children aged 1 to 15 years with first episode of INS with remission within 3 weeks \\
- Number (analysed/randomised): treatment group 1 (124/127); treatment group $2(122 / 128)$ \\
- Mean age \pm SD (years): treatment group 1 (6.3 \pm 4.1$)$; treatment group $2(6.7 \pm 4.1)$ \\
- Sex (M/F): treatment group 1 (87/35); treatment group 2 (89/35) \\
min/1.73 $\mathrm{m}^{2} ;$ active infections; poorly controlled hypertension; severe liver dysfunction; pregnancy \\
or a history of immunosuppressant medication
\end{tabular}

Interventions Treatment group 1 (6 months)

- Prednisolone: $60 \mathrm{mg} / \mathrm{m}^{2}$ weeks $1-4$ in 3 divided doses daily, $60 \mathrm{mg} / \mathrm{m}^{2}$ on alternate days weeks 5 to 8 , $45 \mathrm{mg} / \mathrm{m}^{2}$ on alternate days for weeks 9 to $12,15 \mathrm{mg} / \mathrm{m}^{2}$ on alternate days for weeks 17 to 20

Treatment group 2 (2 months)

- Prednisolone $60 \mathrm{mg} / \mathrm{m}^{2}$ weeks 1 to 4 , in 3 divided doses daily, $40 \mathrm{mg} / \mathrm{m}^{2}$ on alternate days weeks 5 to 8

\begin{tabular}{ll}
\hline Outcomes & Number relapsing by 2 years \\
- Number of patients with frequent relapses at 2 years \\
- Number needing steroid sparing agents at 2 years \\
- Adverse events \\
\hline Notes & - Grant from the Ministry of Health, Labour and Welfare, Japan \\
& $*$ Relapse, FRNS: ISKDC \\
& $*$ Diagnosis of nephrotic syndrome and remission: ISKDC \\
\hline
\end{tabular}

\section{Risk of bias}

\begin{tabular}{lll}
\hline Bias & Authors' judgement & Support for judgement \\
\hline $\begin{array}{l}\text { Random sequence genera- } \\
\text { tion (selection bias) }\end{array}$ & Low risk & $\begin{array}{l}\text { Computer generated sequence in 1:1 ratio, stratified for age (1 to 10 years or } \\
11 \text { to } 15 \text { years), sex and institution }\end{array}$ \\
\hline $\begin{array}{l}\text { Allocation concealment } \\
\text { (selection bias) }\end{array}$ & Low risk & $\begin{array}{l}\text { "Patients were randomly assigned.....at the Japan Clinical Research Support } \\
\text { Unit" }\end{array}$ \\
\hline $\begin{array}{l}\text { Blinding of participants } \\
\begin{array}{l}\text { and personnel (perfor- } \\
\text { mance bias) }\end{array}\end{array}$ & High risk & $\begin{array}{l}\text { Open label, patients, guardians, treating physicians and individuals were data } \\
\text { were not blinded to treatment groups }\end{array}$ \\
\hline
\end{tabular}


Yoshikawa 2014 (Continued)

All outcomes

\begin{tabular}{|c|c|c|}
\hline $\begin{array}{l}\text { Blinding of outcome as- } \\
\text { sessment (detection bias) } \\
\text { All outcomes }\end{array}$ & Low risk & $\begin{array}{l}\text { "Apart from trial statistician and data monitoring committee, all treating } \\
\text { physicians and other investigators remained blinded to the trial results until } \\
\text { follow up was completed" }\end{array}$ \\
\hline
\end{tabular}

All outcomes

follow up was completed"

\begin{tabular}{|c|c|c|}
\hline $\begin{array}{l}\text { ncomplete outcome data } \\
\text { (attrition bias) }\end{array}$ & Low risk & $\begin{array}{l}\text { Excluded 9/255 (3\%): early relapses after remission (5), } 3 \text { no follow-up data } \\
\text { available (3), withdrew consent before allocated study medication (1) }\end{array}$ \\
\hline
\end{tabular}
available (3), withdrew consent before allocated study medication (1)

All outcomes

Selective reporting (re- Low risk $\quad$ All studies pre-specified outcomes mentioned
porting bias)

porting bias)

\begin{tabular}{ll}
\hline Other bias $\quad$ Low risk $\quad$ Grant from the Ministry of Health, Labour and Welfare, Japan \\
\hline
\end{tabular}

Zhang 2014

\begin{tabular}{ll}
\hline Methods & Study design: parallel RCT \\
- & Time frame: November 2009 to May 2012 \\
- & Follow-up: 6 months \\
\hline Participants & Country: China \\
- Setting: single centre & Inclusion criteria: children, treated with prednisone for first time, no previous medications, have nor- \\
& mal liver and renal functions, no concurrent infection, no systemic signs such as fever, normal white \\
& cell count, negative elisa-linked immunospot or negative PPD \\
- & Number (analysed/randomised): treatment group 1 (95/106); treatment group 2 (98/105) \\
- & Mean age, range (years): treatment group 1 (4.0, 1.0 to 15.0); treatment group 2 (3.0, 0.7 to 17.0) \\
- Sex (M/F): treatment group 1 (71/24); treatment group 2 (73/25) \\
- Exclusion criteria: secondary nephrotic syndrome; glomerular haematuria; repeated or sustained hy- \\
pertension; impaired kidney function except for hypovolaemia; hypocomplementaemia; severe infec- \\
tions after prednisone; received incomplete course of azithromycin
\end{tabular}

Interventions

Treatment group 1

- Prednisone: $2 \mathrm{mg} / \mathrm{kg}$ daily (maximum $60 \mathrm{mg} / \mathrm{kg} / \mathrm{d}$ ) in divided doses for 4 weeks, $1.5 \mathrm{mg} / \mathrm{kg}$ on alternate days for 4 weeks, decrease by $5 \mathrm{mg}$ every 2 weeks till $30 \mathrm{mg} / \mathrm{kg}$, then decrease by $2.5 \mathrm{mg}$ very every 2 weeks until withdrawal

- Azithromycin: $10 \mathrm{mg} / \mathrm{kg}$ daily for 3 days

Treatment group 2

- Prednisone: $2 \mathrm{mg} / \mathrm{kg}$ daily (maximum $60 \mathrm{mg} / \mathrm{kg} / \mathrm{d}$ ) in divided doses for 4 weeks, $1.5 \mathrm{mg} / \mathrm{kg}$ on alternate days for 4 weeks, decrease by $5 \mathrm{mg}$ every 2 weeks till $30 \mathrm{mg} / \mathrm{kg}$, then decrease by $2.5 \mathrm{mg}$ every 2 weeks every 2 weeks until withdrawal

\begin{tabular}{ll}
\hline Outcomes & - Number relapsing by 3 months \\
- Number relapsing by 6 months \\
- Number with frequent relapses at 6 months \\
- Time to remission
\end{tabular}


Zhang 2014 (Continued)

Notes

- Definitions

* Primary nephrotic syndrome: treated with prednisone for first time

* SRNS: no complete remission after treatment with $2 \mathrm{mg} / \mathrm{kg} /$ day for 8 weeks

* Relapse: morning urinalysis showed $\geq 3+$ proteinuria after being negative for 3 days during follow-up of 6 months

* Complete remission: negative or trace proteinuria for 3 consecutive days, serum albumin $\geq 2.5 \mathrm{~g} / \mathrm{L}$

\section{Risk of bias}

\begin{tabular}{|c|c|c|}
\hline Bias & Authors' judgement & Support for judgement \\
\hline $\begin{array}{l}\text { Random sequence genera- } \\
\text { tion (selection bias) }\end{array}$ & High risk & $\begin{array}{l}\text { "randomly categorized into intervention and control groups using a random } \\
\text { number table of odd or even numbers" }\end{array}$ \\
\hline $\begin{array}{l}\text { Allocation concealment } \\
\text { (selection bias) }\end{array}$ & High risk & Allocation sequence could be predicted \\
\hline $\begin{array}{l}\text { Blinding of participants } \\
\text { and personnel (perfor- } \\
\text { mance bias) } \\
\text { All outcomes }\end{array}$ & High risk & No blinding and lack of blinding could influence management \\
\hline $\begin{array}{l}\text { Blinding of outcome as- } \\
\text { sessment (detection bias) } \\
\text { All outcomes }\end{array}$ & High risk & No blinding and lack of blinding could influence outcome assessment \\
\hline $\begin{array}{l}\text { Incomplete outcome data } \\
\text { (attrition bias) } \\
\text { All outcomes }\end{array}$ & Low risk & $\begin{array}{l}\text { 21/208 (excludes } 4 \text { patients with SRNS); } 10.1 \% \text { lost to follow-up or excluded } \\
\text { (15 lost to follow-up, } 6 \text { excluded for hypocomplementaemia) }\end{array}$ \\
\hline $\begin{array}{l}\text { Selective reporting (re- } \\
\text { porting bias) }\end{array}$ & High risk & $\begin{array}{l}\text { Not all reviews prespecified outcomes are mentioned - no adverse events } \\
\text { mentioned }\end{array}$ \\
\hline Other bias & Low risk & $\begin{array}{l}\text { Tiajin Bureau of Health Sciences and Technology Fund. Project number } \\
09 K Z 34\end{array}$ \\
\hline
\end{tabular}

APN - Arbetsgemeinschaft für Pädiatrische Nephrologie; BMI - body mass index; CPA - cyclophosphamide; $\mathrm{CrCl}$ - $\mathrm{creatinine} \mathrm{clearance;} \mathrm{CPA} \mathrm{-}$ cyclophosphamide; CSA - cyclosporin; eGFR - estimated glomerular filtration rate; FRNS - frequently relapsing steroid-sensitive nephrotic syndrome; INS - idiopathic nephrotic syndrome; IQR - interquartile range; ISKDC - International Study of Kidney Disease in Children; SCr - serum creatinine; SDNS - steroid-dependent nephrotic syndrome; SSNS - steroid-sensitive nephrotic syndrome; SRNS - steroid-resistant nephrotic syndrome; URTI - upper respiratory tract infection

Characteristics of excluded studies [ordered by study ID]

\begin{tabular}{ll}
\hline Study & Reason for exclusion \\
\hline Alatas 1978 & RCT; non-corticosteroid interventions (chlorambucil) \\
\hline Anonymous 1968 & Not RCT \\
\hline APN 1982 & RCT, non-corticosteroid interventions (cyclophosphamide/chlorambucil) \\
\hline Arun 2009 & RCT; non-corticosteroid interventions (zinc) \\
\hline Baluarte 1978 & RCT; non-corticosteroid interventions (chlorambucil) \\
\hline
\end{tabular}




\begin{tabular}{|c|c|}
\hline Study & Reason for exclusion \\
\hline BAPN 1991 & RCT; non-corticosteroid interventions (levamisole) \\
\hline Barratt 1970 & RCT; non-corticosteroid interventions (cyclophosphamide) \\
\hline Barratt 1973 & RCT; non-corticosteroid interventions (cyclophosphamide) \\
\hline Barratt 1977 & RCT; non-corticosteroid interventions (azathioprine) \\
\hline Cerkauskiene 2005 & RCT; non-corticosteroid interventions (fusidic acid) \\
\hline Chiu 1973 & RCT; non-corticosteroid interventions (cyclophosphamide) \\
\hline Dayal 1994 & RCT; non-corticosteroid interventions (levamisole) \\
\hline Donia 2005 & RCT; non-corticosteroid interventions (cyclophosphamide/levamisole) \\
\hline Edefonti 1988 & RCT; non-corticosteroid interventions (cyclosporin/cyclophosphamide) \\
\hline Grupe 1976 & RCT; non-corticosteroid interventions (chlorambucil) \\
\hline Hu 2006 & Probably RCT; non-corticosteroid interventions (herbal medicines) \\
\hline Idczak-Nowicka 1996 & Not RCT \\
\hline ISKDC 1970 & RCT; non-corticosteroid interventions (azathioprine) \\
\hline ISKDC 1974 & RCT; non-corticosteroid interventions (cyclophosphamide) \\
\hline Liu 1995 & Non-corticosteroid interventions (Chinese medicines). Not sure whether it is RCT \\
\hline Martinelli 2004 & $\begin{array}{l}\text { Non-corticosteroid interventions (cyclophosphamide) in children with FSGS. Not sure whether it is } \\
\text { RCT }\end{array}$ \\
\hline McCrory 1973 & RCT; non-corticosteroid interventions (cyclophosphamide) \\
\hline Niaudet 1992 & RCT; non-corticosteroid interventions (cyclosporin/chlorambucil) \\
\hline Prasad 2004 & RCT; non-corticosteroid interventions (cyclophosphamide) \\
\hline Rashid 1996 & RCT; non-corticosteroid interventions (levamisole) \\
\hline Sharipov 2007 & Not RCT \\
\hline Ueda 1990 & RCT; non-corticosteroid interventions (cyclophosphamide) \\
\hline Wang 2005 & Possibly RCT; non-corticosteroid interventions \\
\hline Weiss 1993 & RCT; non-corticosteroid interventions (levamisole) \\
\hline Wingen 1990 & Not RCT \\
\hline Yamashita 1971 & Not RCT \\
\hline Yang 2001 & Non-corticosteroid interventions (herbal). Unclear wheth \\
\hline
\end{tabular}




\section{Study \\ Reason for exclusion}

Yoshioka 2000

RCT; non-corticosteroid interventions (mizoribine)

FSGS - focal segmental glomerulonephritis; RCT - randomised controlled trial

Characteristics of ongoing studies [ordered by study ID]

\section{PREDNOS 2 Study 2014}

Trial name or title

Short course daily prednisolone therapy at the time of upper respiratory infection in children with relapsing steroid sensitive nephrotic syndrome: The PREDNOS 2 study

\begin{tabular}{ll}
\hline Methods & Parallel RCT \\
\hline Participants & $\begin{array}{l}\text { Subjects aged over } 1 \text { year and less than } 19 \text { years with relapsing SSNS who have had two or more re- } \\
\text { lapses in the preceding } 12 \text { months }\end{array}$ \\
\hline
\end{tabular}

\begin{tabular}{ll}
\hline Interventions & $\begin{array}{l}\text { Standard course therapy: weeks } 1 \text { to } 4 \text { prednisolone } 60 \mathrm{mg} / \mathrm{m}^{2} / \mathrm{d} \text { (max } 80 \mathrm{mg} \text { ), weeks } 5 \text { to } 8 \text {, pred- } \\
\text { nisolone } 40 \mathrm{mg} / \mathrm{m}^{2} \text { on alternate days for } 28 \text { days }\end{array}$
\end{tabular}

Extended course therapy: weeks 1 to $460 \mathrm{mg} / \mathrm{m}^{2} / \mathrm{d}$, weeks 5 to 16 prednisolone $60 \mathrm{mg} / \mathrm{m}^{2}$ on alternate days tapering by $10 \mathrm{mg} / \mathrm{m}^{2}$ every 2 weeks

Outcomes

The primary end point will be the incidence of URTI-related relapse following the first URTI during the 12 month follow-up period

\section{Starting date}

Contact information

Nicholas Webb. nicholas.webb@cmft.nhs.uk

\section{Notes}

\section{PREDNOS Study 2013}

\begin{tabular}{ll}
\hline Trial name or title & $\begin{array}{l}\text { Long-term tapering versus standard prednisolone (steroid) therapy for the treatment of the initial } \\
\text { episode of nephrotic syndrome: national multicentre randomised double blind trial }\end{array}$ \\
\hline Methods & Parallel RCT \\
\hline Participants & Children presenting with first episode of SSNS, over 1 year and less than 1 year \\
\hline Interventions & $\begin{array}{l}\text { Treatment group: children will receive daily prednisolone for } 6 \text { days at the onset of URTI at the on- } \\
\text { set of each URTI during } 12 \text { months } \\
\text { Control group: children will continue their current treatment (with placebo to maintain double } \\
\text { blind) at the onset of each URTI during } 12 \text { months }\end{array}$ \\
\hline Outcomes & $\begin{array}{l}\text { Time to first relapse. To determine whether an extended course of prednisolone reduces the re- } \\
\text { lapse rate, reduces the proportion of children who develop frequently relapsing or steroid depen- } \\
\text { dent disease, reduces the requirement for a second or third line agent, is associated with an in- } \\
\text { creased incidence of steroid related adverse events including behavioural problems, is more effec- } \\
\text { tive than standard course therapy }\end{array}$ \\
\hline
\end{tabular}

Starting date 
PREDNOS Study 2013 (Continued)

Contact information

nicholas.webb@cmft.nhs.uk

Notes

SSNS - steroid-sensitive nephrotic syndrome; URTI - upper respiratory tract infection

DATA AND ANALYSES

Comparison 1. Steroid therapy in first episode of nephrotic syndrome: 3 months versus 2 months of therapy

\begin{tabular}{llllll}
\hline Outcome or subgroup title & $\begin{array}{l}\text { No. of } \\
\text { studies }\end{array}$ & $\begin{array}{l}\text { No. of } \\
\text { partici- } \\
\text { pants }\end{array}$ & Statistical method & Effect size \\
\hline $\begin{array}{l}1 \text { Number with frequent relaps- } \\
\text { es by } 12 \text { to } 24 \text { months }\end{array}$ & 6 & 582 & Risk Ratio (M-H, Random, 95\% Cl) & $0.68[0.47,1.00]$ \\
\hline $\begin{array}{l}2 \text { Number of children relapsing } \\
\text { by } 12 \text { to } 24 \text { months }\end{array}$ & 8 & 741 & Risk Ratio (M-H, Random, 95\% Cl) & $0.80[0.64,1.00]$ \\
\hline $\begin{array}{l}3 \text { Mean relapse rate/patient/y } \\
4 \text { Cumulative steroid dose }\end{array}$ & 4 & 295 & Mean Difference (IV, Random, 95\% Cl) & $-0.65[-1.29,-0.00]$ \\
\hline $\begin{array}{l}5 \text { Number with frequent relaps- } \\
\text { es by } 12 \text { to } 24 \text { months stratified } \\
\text { by definition of FRNS }\end{array}$ & 6 & 245 & Mean Difference (IV, Random, 95\% Cl) & $0.71[-0.67,2.09]$ \\
\hline
\end{tabular}

\begin{tabular}{llclc}
\hline 5.1 FRNS by ISKDC definition & 3 & 435 & Risk Ratio (M-H, Random, 95\% Cl) & $0.68[0.39,1.20]$ \\
\hline $\begin{array}{l}5.2 \text { Variation from ISKDC defini- } \\
\text { tion of FRNS }\end{array}$ & 3 & 147 & Risk Ratio (M-H, Random, 95\% Cl) & $0.64[0.35,1.19]$ \\
\hline $\begin{array}{l}6 \text { Number with frequent relaps- } \\
\text { es by } 12 \text { to } 24 \text { months strati- } \\
\text { fied by risk of bias for allocation } \\
\text { concealment }\end{array}$ & 6 & 582 & Risk Ratio (M-H, Random, 95\% Cl) & $0.68[0.47,1.00]$ \\
\hline
\end{tabular}

\begin{tabular}{lllll}
\hline $\begin{array}{l}\text { 6.1 Low risk of bias for alloca- } \\
\text { tion concealment }\end{array}$ & 3 & 362 & Risk Ratio (M-H, Random, 95\% Cl) & $0.92[0.69,1.23]$ \\
\hline $\begin{array}{l}\text { 6.2 Unclear or high risk of bias } \\
\text { for allocation bias }\end{array}$ & 3 & 220 & Risk Ratio (M-H, Random, 95\% Cl) & $0.45[0.26,0.77]$ \\
\hline 7 Adverse events & 6 & & Risk Ratio (M-H, Random, 95\% Cl) & Subtotals only \\
\hline 7.1 Psychological disorders & 3 & 233 & Risk Ratio (M-H, Random, 95\% Cl) & $2.18[0.43,11.13]$ \\
\hline 7.2 Hypertension & 6 & 456 & Risk Ratio (M-H, Random, 95\% Cl) & $1.79[0.47,6.86]$ \\
\hline 7.3 Ophthalmological disorders & 5 & 400 & Risk Ratio (M-H, Random, 95\% Cl) & $0.32[0.07,1.42]$ \\
\hline 7.4 Retarded growth & 4 & 354 & Risk Ratio (M-H, Random, 95\% Cl) & $0.54[0.25,1.18]$ \\
\hline
\end{tabular}




\begin{tabular}{lllll}
\hline Outcome or subgroup title & $\begin{array}{l}\text { No. of } \\
\text { studies }\end{array}$ & $\begin{array}{l}\text { No. of } \\
\text { partici- } \\
\text { pants }\end{array}$ & Statistical method & Effect size \\
\hline 7.5 Cushing's syndrome & 3 & 232 & Risk Ratio (M-H, Random, 95\% Cl) & $1.32[0.51,3.39]$ \\
\hline 7.6 Infections & 2 & 172 & Risk Ratio (M-H, Random, 95\% Cl) & $0.79[0.53,1.17]$ \\
\hline 7.7 Osteoporosis & 3 & 233 & Risk Ratio (M-H, Random, $95 \% \mathrm{Cl})$ & $0.47[0.06,3.38]$ \\
\hline
\end{tabular}

\section{Analysis 1.1. Comparison 1 Steroid therapy in first episode of nephrotic syndrome: 3 months versus $\mathbf{2}$ months of therapy, Outcome 1 Number with frequent relapses by 12 to 24 months.}

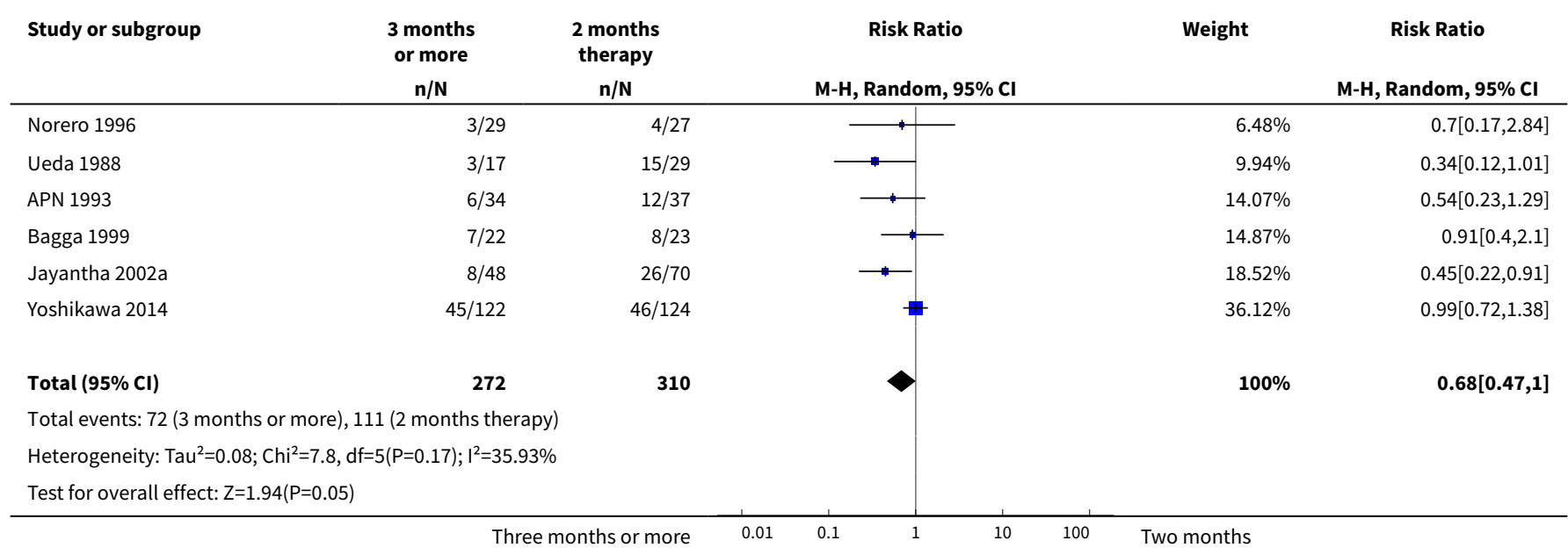

\section{Analysis 1.2. Comparison 1 Steroid therapy in first episode of nephrotic syndrome: 3 months versus 2 months of therapy, Outcome 2 Number of children relapsing by 12 to 24 months.}

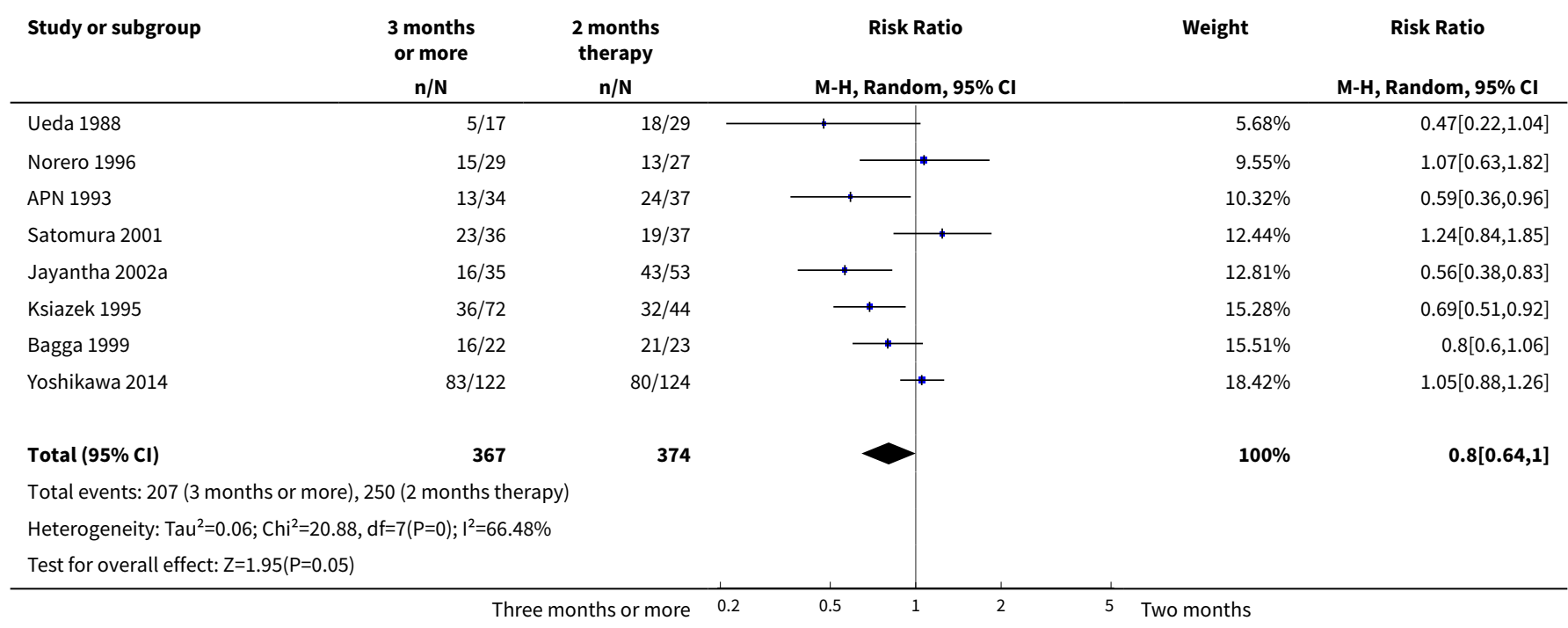


Analysis 1.3. Comparison 1 Steroid therapy in first episode of nephrotic syndrome: 3 months versus 2 months of therapy, Outcome 3 Mean relapse rate/patient/y.

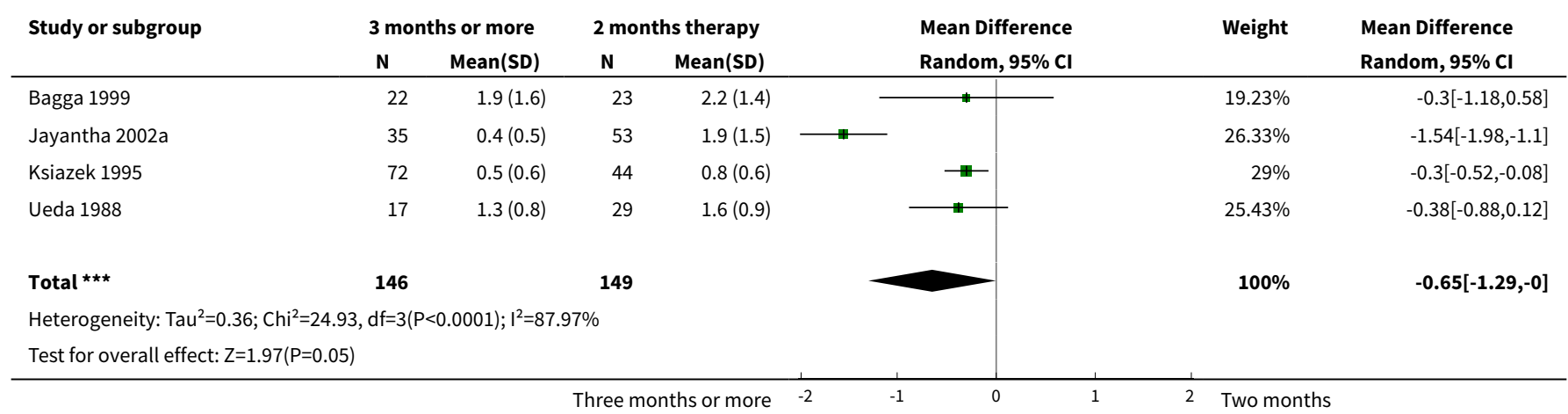

Analysis 1.4. Comparison 1 Steroid therapy in first episode of nephrotic syndrome: 3 months versus 2 months of therapy, Outcome 4 Cumulative steroid dose.

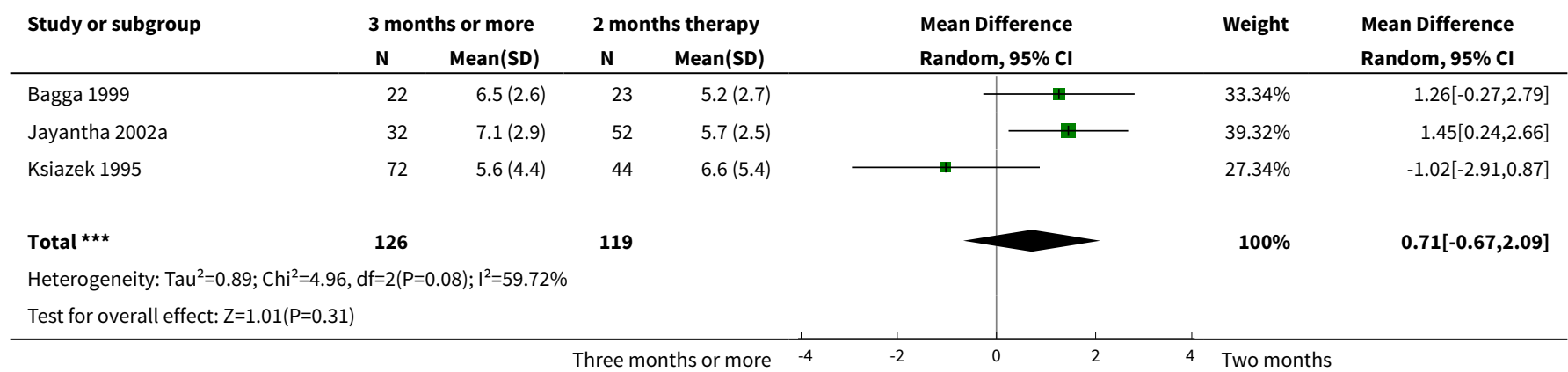

Analysis 1.5. Comparison 1 Steroid therapy in first episode of nephrotic syndrome: 3 months versus 2 months of therapy, Outcome 5 Number with frequent relapses by 12 to 24 months stratified by definition of FRNS.

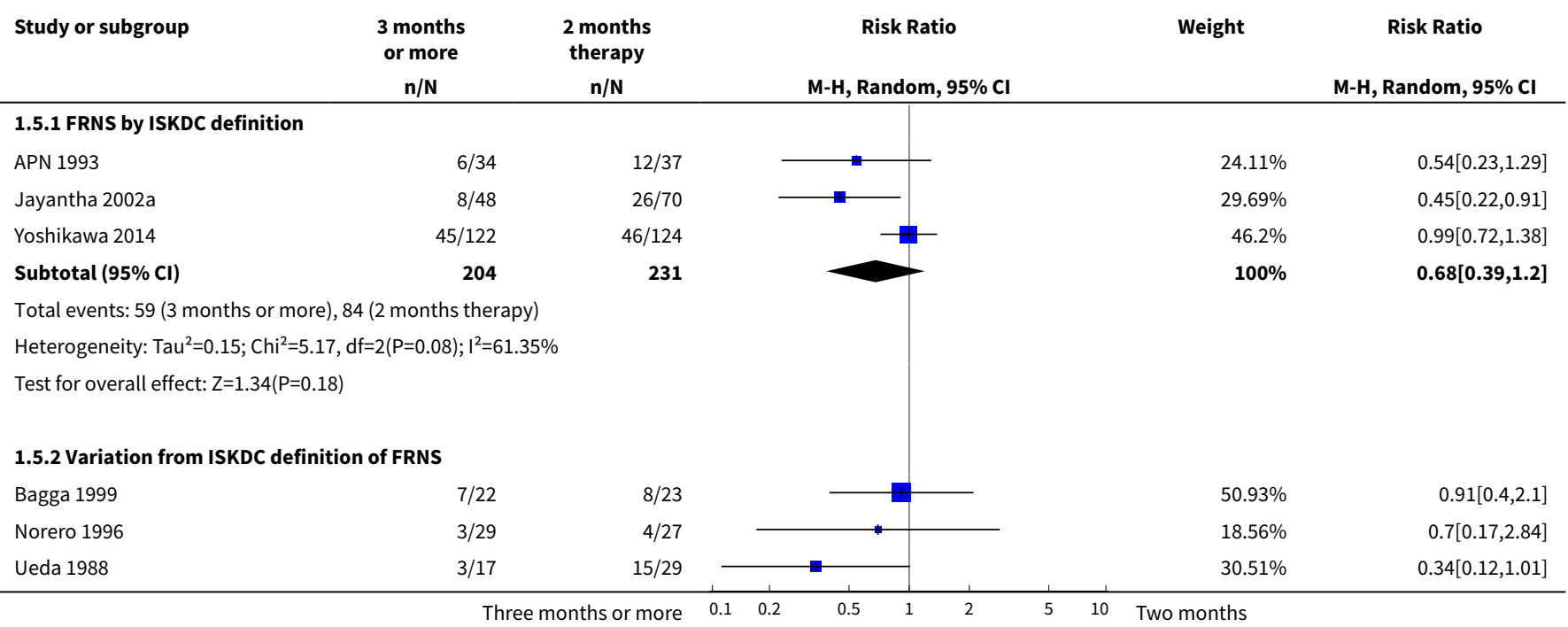




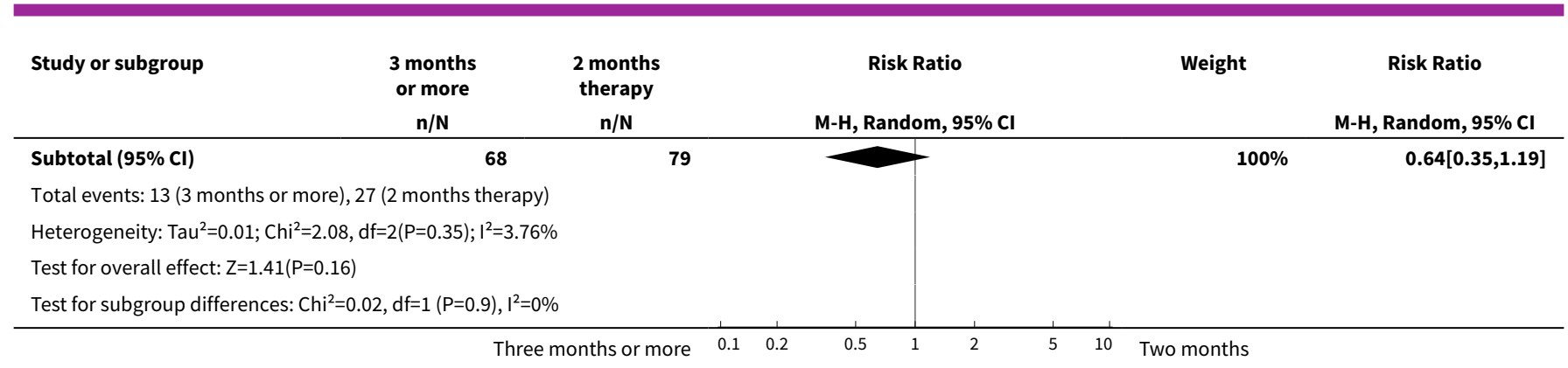

Analysis 1.6. Comparison 1 Steroid therapy in first episode of nephrotic syndrome: 3 months versus 2 months of therapy, Outcome 6 Number with frequent relapses by 12 to 24 months stratified by risk of bias for allocation concealment.

\begin{tabular}{|c|c|c|c|c|c|}
\hline \multirow[t]{2}{*}{ Study or subgroup } & $\begin{array}{l}3 \text { months } \\
\text { or more }\end{array}$ & $\begin{array}{l}2 \text { months } \\
\text { therapy }\end{array}$ & Risk Ratio & Weight & Risk Ratio \\
\hline & $n / N$ & $n / N$ & M-H, Random, $95 \% \mathrm{Cl}$ & & M-H, Random, $95 \% \mathrm{Cl}$ \\
\hline
\end{tabular}

1.6.1 Low risk of bias for allocation concealment

APN 1993

Bagga 1999

Yoshikawa 2014

Subtotal $(95 \% \mathrm{CI})$

\section{$6 / 34$}

$7 / 22$

$45 / 122$

178

Total events: 58 ( 3 months or more), 66 ( 2 months therapy)

Heterogeneity: $\mathrm{Tau}^{2}=0 ; \mathrm{Chi}^{2}=1.66, \mathrm{df}=2(\mathrm{P}=0.44) ; \mathrm{I}^{2}=0 \%$

Test for overall effect: $Z=0.56(P=0.57)$

1.6.2 Unclear or high risk of bias for allocation bias

Norero 1996

Ueda 1988

Jayantha $2002 a$

Subtotal $(95 \% \mathrm{Cl})$

Total events: 14 ( 3 months or more), 45 ( 2 months therapy)

Heterogeneity: $\mathrm{Tau}^{2}=0 ; \mathrm{Chi}^{2}=0.63, \mathrm{df}=2(\mathrm{P}=0.73) ; \mathrm{I}^{2}=0 \%$

Test for overall effect: $Z=2.9(P=0)$

Total $(95 \% \mathrm{CI})$

Total events: 72 (3 months or more), 111 (2 months therapy) Heterogeneity: $\mathrm{Tau}^{2}=0.08 ; \mathrm{Chi}^{2}=7.8, \mathrm{df}=5(\mathrm{P}=0.17) ; \mathrm{I}^{2}=35.93 \%$

Test for overall effect: $Z=1.94(P=0.05)$

Test for subgroup differences: $\mathrm{Chi}^{2}=5.3, \mathrm{df}=1(\mathrm{P}=0.02), \mathrm{I}^{2}=81.13 \%$ $\mathrm{n} / \mathrm{N}$

M-H, Random, 95\% Cl
$14.07 \%$

$14.87 \%$

$36.12 \%$

$65.06 \%$
$0.54[0.23,1.29]$

$0.91[0.4,2.1]$

$0.99[0.72,1.38]$

$0.92[0.69,1.23]$
272

$3 / 29$

$3 / 17$

$8 / 48$

94

Three months or more
$4 / 27$

$15 / 29$

26/70

126

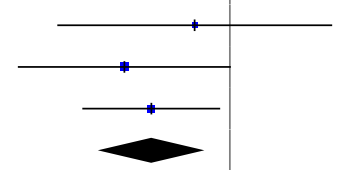

$6.48 \%$

$9.94 \%$

$18.52 \%$

$34.94 \%$

$100 \%$
$0.7[0.17,2.84]$

$0.34[0.12,1.01]$

$0.45[0.22,0.91]$

$\mathbf{0 . 4 5}[0.26,0.77]$
310

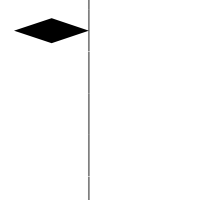

Analysis 1.7. Comparison 1 Steroid therapy in first episode of nephrotic syndrome: $\mathbf{3}$ months versus $\mathbf{2}$ months of therapy, Outcome 7 Adverse events.

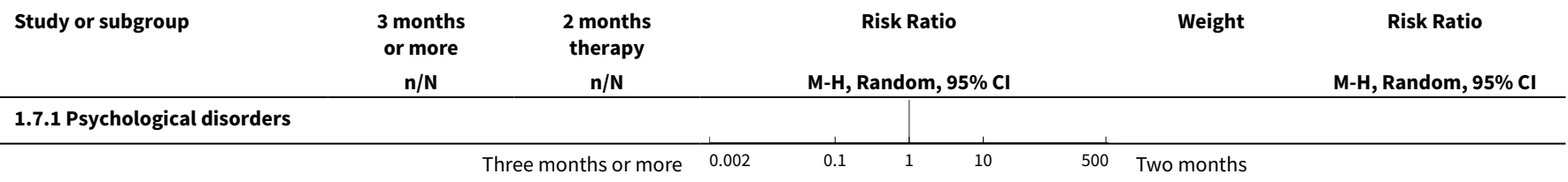




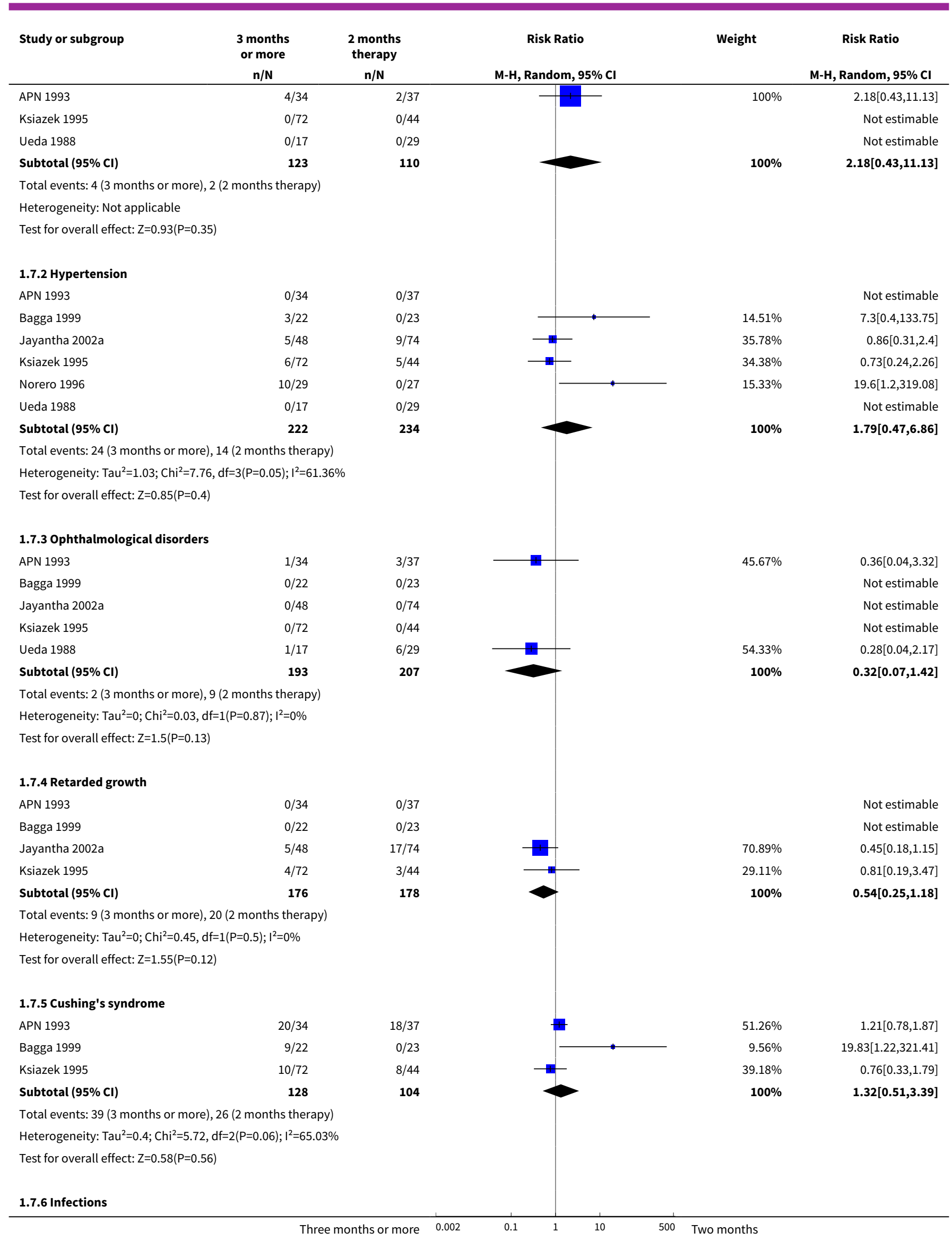




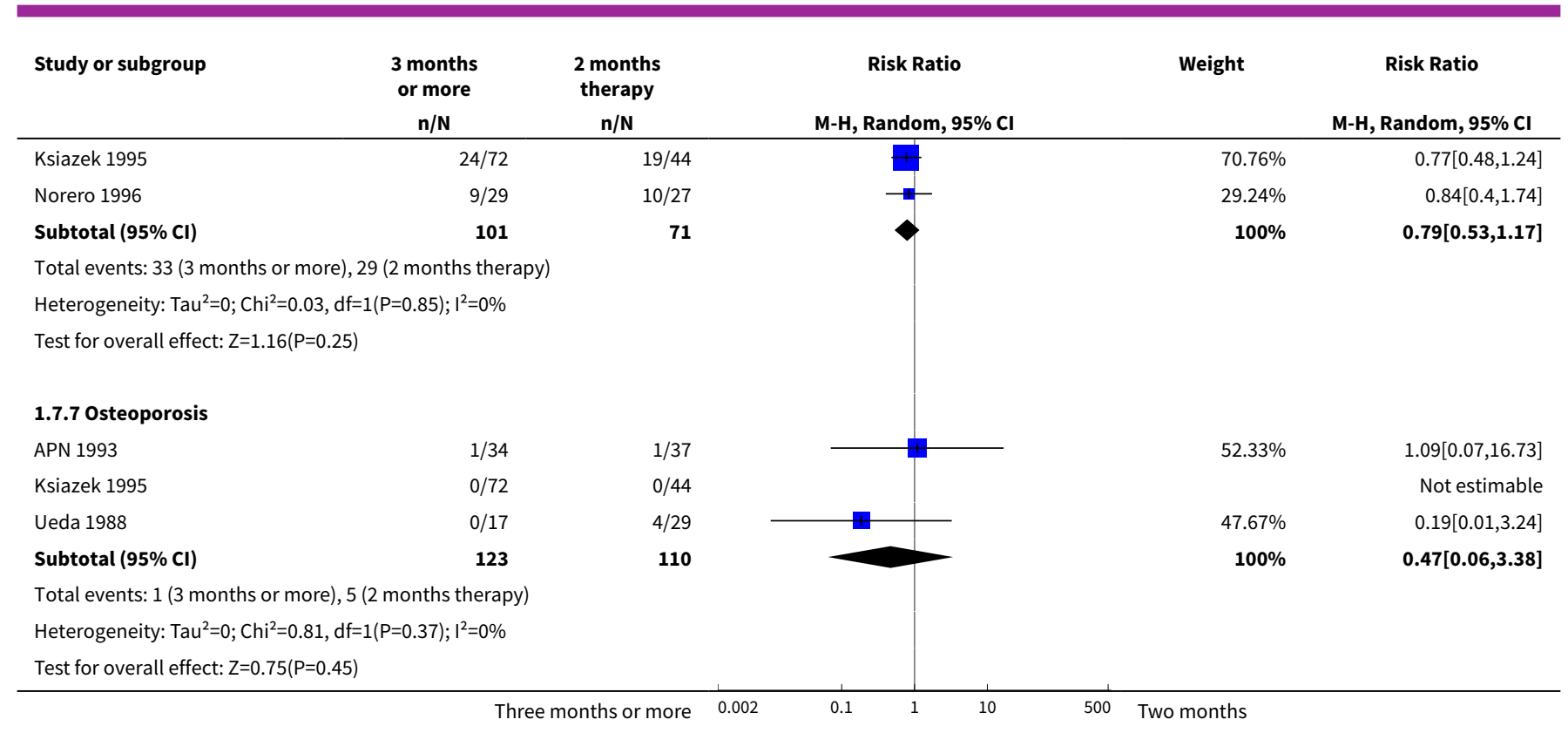

Comparison 2. Steroid therapy in first episode of nephrotic syndrome: 5 or 6 months versus 3 months of therapy

\begin{tabular}{|c|c|c|c|c|}
\hline Outcome or subgroup title & $\begin{array}{l}\text { No. of } \\
\text { studies }\end{array}$ & $\begin{array}{l}\text { No. of } \\
\text { partici- } \\
\text { pants }\end{array}$ & Statistical method & Effect size \\
\hline $\begin{array}{l}1 \text { Number with frequent relapses } \\
\text { by } 12 \text { to } 24 \text { months }\end{array}$ & 5 & 591 & Risk Ratio (M-H, Random, 95\% Cl) & $0.78[0.50,1.22]$ \\
\hline $\begin{array}{l}2 \text { Number of children relapsing } \\
\text { by } 12 \text { to } 24 \text { months }\end{array}$ & 7 & 763 & Risk Ratio (M-H, Random, 95\% Cl) & $0.62[0.45,0.85]$ \\
\hline 3 Mean relapse rate/patient/y & 3 & 460 & Mean Difference (IV, Random, 95\% CI) & $-0.39[-0.64,-0.14]$ \\
\hline 4 Cumulative steroid dose & 3 & 460 & Mean Difference (IV, Random, 95\% CI) & $-0.47[-1.67,0.73]$ \\
\hline $\begin{array}{l}5 \text { Number with frequent relapses } \\
\text { stratified by definition of FRNS }\end{array}$ & 5 & & Risk Ratio (M-H, Random, 95\% Cl) & Subtotals only \\
\hline 5.1 FRNS by ISKDC definition & 3 & 377 & Risk Ratio (M-H, Random, 95\% Cl) & $1.00[0.74,1.34]$ \\
\hline $\begin{array}{l}5.2 \text { Variation from ISKDC defini- } \\
\text { tion of FRNS }\end{array}$ & 2 & 214 & Risk Ratio (M-H, Random, 95\% Cl) & $0.36[0.18,0.72]$ \\
\hline $\begin{array}{l}6 \text { Number with frequent relapses } \\
\text { stratified by risk of bias for allo- } \\
\text { cation concealment }\end{array}$ & 5 & 591 & Risk Ratio (M-H, Random, 95\% Cl) & $0.78[0.50,1.22]$ \\
\hline $\begin{array}{l}6.1 \text { Studies at low risk of bias for } \\
\text { allocation concealment }\end{array}$ & 3 & 377 & Risk Ratio (M-H, Random, 95\% Cl) & $1.00[0.74,1.34]$ \\
\hline $\begin{array}{l}\text { 6.2 Studies at high or unclear risk } \\
\text { of bias for allocation conceal- } \\
\text { ment }\end{array}$ & 2 & 214 & Risk Ratio (M-H, Random, 95\% Cl) & $0.36[0.18,0.72]$ \\
\hline
\end{tabular}




\begin{tabular}{|c|c|c|c|c|}
\hline Outcome or subgroup title & $\begin{array}{l}\text { No. of } \\
\text { studies }\end{array}$ & $\begin{array}{l}\text { No. of } \\
\text { partici- } \\
\text { pants }\end{array}$ & Statistical method & Effect size \\
\hline $\begin{array}{l}7 \text { Number with frequent relapses } \\
\text { stratified by risk of bias for blind- } \\
\text { ing }\end{array}$ & 5 & 591 & Risk Ratio (M-H, Random, 95\% Cl) & $0.77[0.51,1.16]$ \\
\hline 7.1 Low risk of bias for blinding & 2 & 307 & Risk Ratio (M-H, Random, 95\% Cl) & $1.02[0.87,1.20]$ \\
\hline $\begin{array}{l}7.2 \text { High or unclear risk of bias for } \\
\text { blinding }\end{array}$ & 3 & 284 & Risk Ratio $(\mathrm{M}-\mathrm{H}$, Random, 95\% Cl) & $0.49[0.30,0.78]$ \\
\hline $\begin{array}{l}8 \text { Number with frequent relapses } \\
\text { stratified by risk of bias for attri- } \\
\text { tion }\end{array}$ & 5 & 591 & Risk Ratio (M-H, Random, 95\% Cl) & $0.77[0.51,1.16]$ \\
\hline 8.1 Low risk of bias for attrition & 4 & 451 & Risk Ratio $(\mathrm{M}-\mathrm{H}$, Random, 95\% Cl) & $0.99[0.85,1.16]$ \\
\hline 8.2 High risk of bias for attrition & 1 & 140 & Risk Ratio $(\mathrm{M}-\mathrm{H}$, Random, 95\% Cl) & $0.33[0.16,0.69]$ \\
\hline 9 Adverse events & 5 & & Risk Ratio (M-H, Random, 95\% Cl) & Subtotals only \\
\hline 9.1 Hypertension & 5 & 636 & Risk Ratio (M-H, Random, 95\% Cl) & $1.37[0.91,2.05]$ \\
\hline 9.2 Eye complications & 5 & 614 & Risk Ratio (M-H, Random, 95\% Cl) & $0.46[0.18,1.17]$ \\
\hline 9.3 Infections & 4 & 586 & Risk Ratio (M-H, Random, 95\% Cl) & $1.09[0.79,1.51]$ \\
\hline 9.4 Cushingoid appearance & 5 & 646 & Risk Ratio (M-H, Random, 95\% Cl) & $0.92[0.62,1.36]$ \\
\hline 9.5 Gastrointestinal bleeding & 1 & 140 & Risk Ratio (M-H, Random, 95\% Cl) & $1.5[0.26,8.70]$ \\
\hline 9.6 Addisonian crisis & 1 & 140 & Risk Ratio $(\mathrm{M}-\mathrm{H}$, Random, 95\% Cl) & $0.5[0.05,5.39]$ \\
\hline 9.7 Psychological disorders & 3 & 389 & Risk Ratio $(\mathrm{M}-\mathrm{H}$, Random, 95\% Cl) & $0.38[0.03,4.39]$ \\
\hline 9.8 Growth & 2 & 320 & Risk Ratio $(\mathrm{M}-\mathrm{H}$, Random, 95\% Cl) & $1.00[0.55,1.82]$ \\
\hline
\end{tabular}

\section{Analysis 2.1. Comparison 2 Steroid therapy in first episode of nephrotic syndrome: 5 or 6 months versus 3 months of therapy, Outcome 1 Number with frequent relapses by 12 to 24 months.}

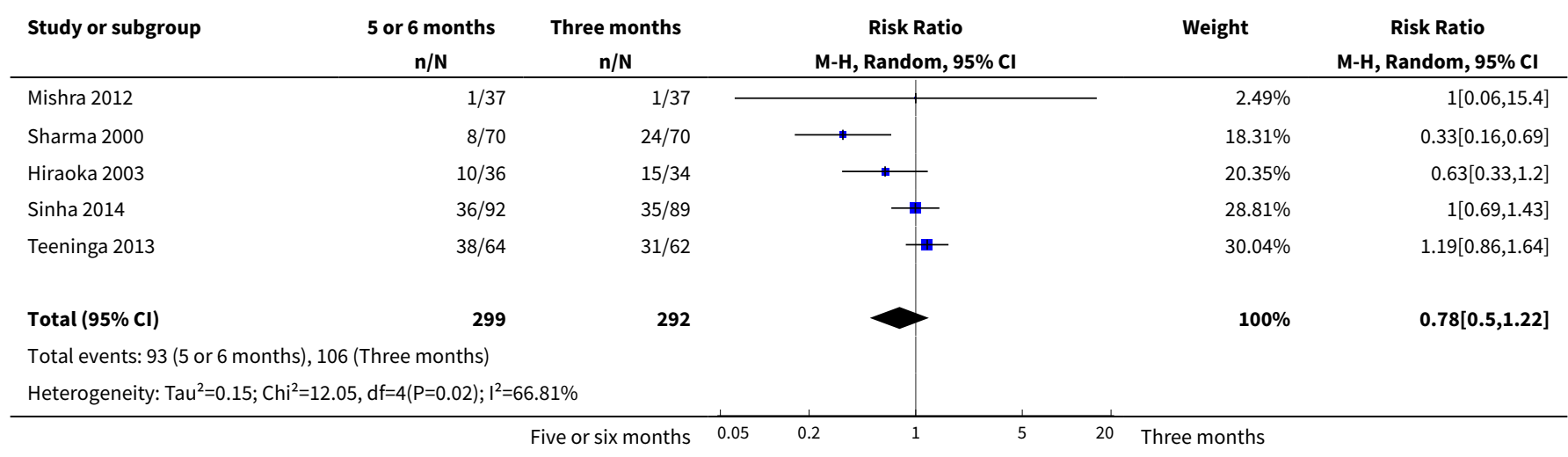




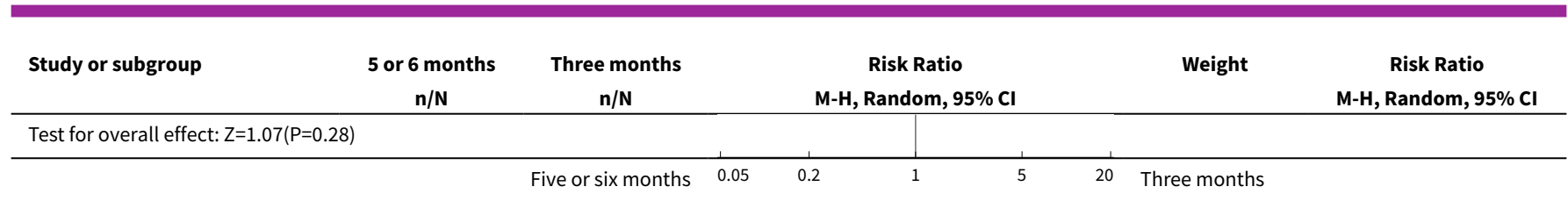

Analysis 2.2. Comparison 2 Steroid therapy in first episode of nephrotic syndrome: 5 or 6 months versus 3 months of therapy, Outcome 2 Number of children relapsing by 12 to 24 months.

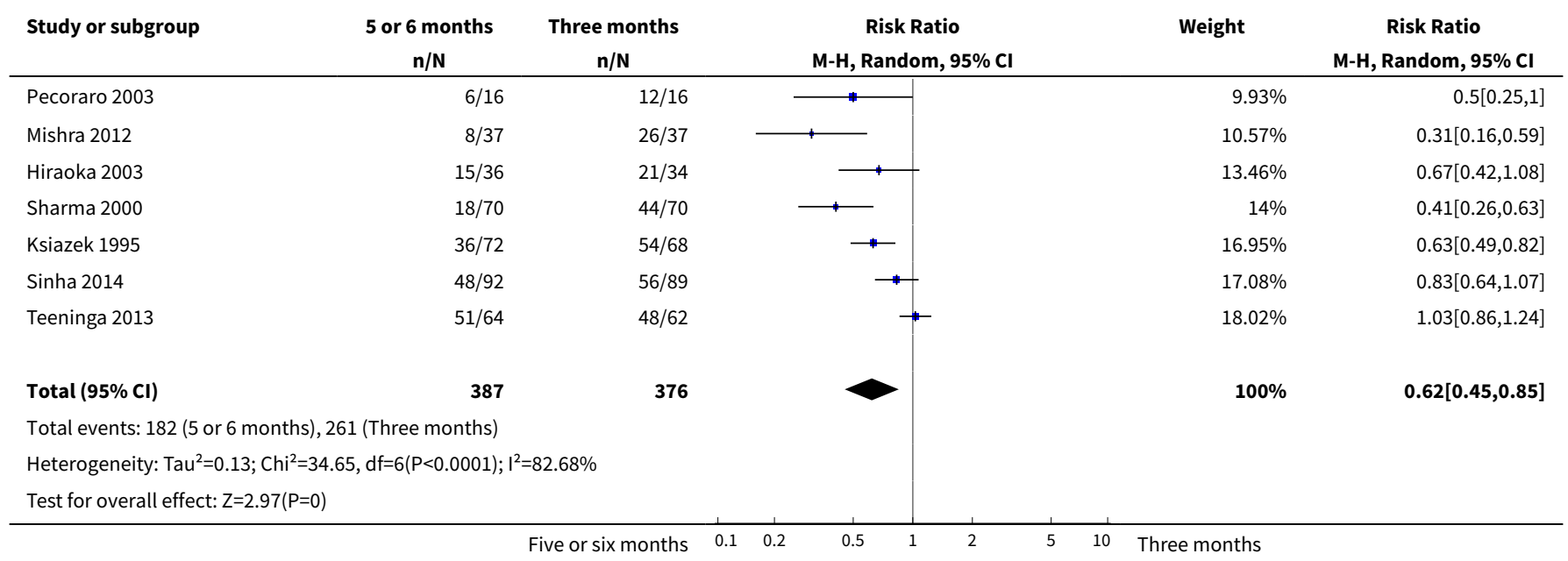

Analysis 2.3. Comparison 2 Steroid therapy in first episode of nephrotic syndrome: 5 or 6 months versus 3 months of therapy, Outcome 3 Mean relapse rate/patient/y.

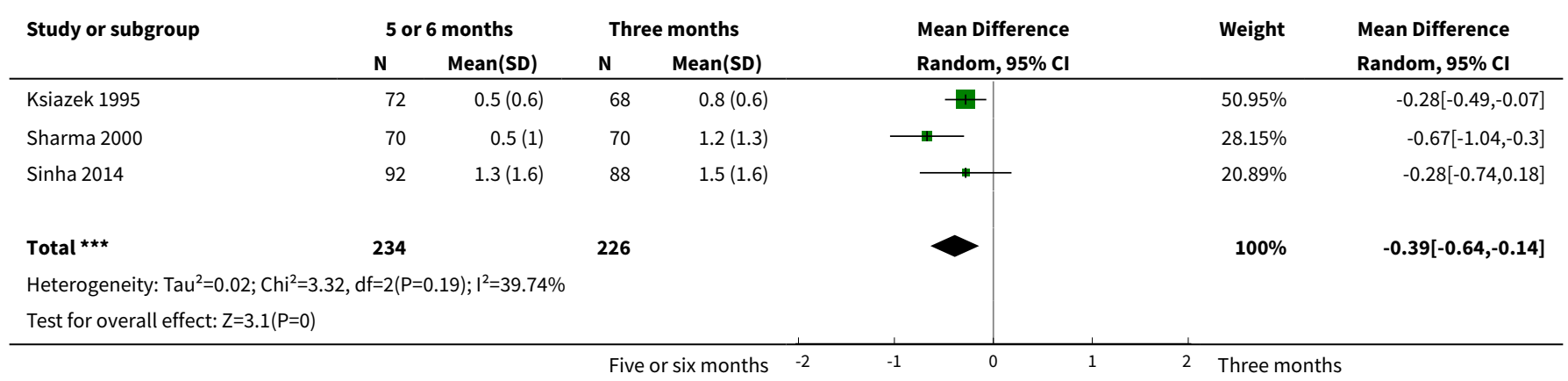

Analysis 2.4. Comparison 2 Steroid therapy in first episode of nephrotic syndrome: 5 or 6 months versus 3 months of therapy, Outcome 4 Cumulative steroid dose.

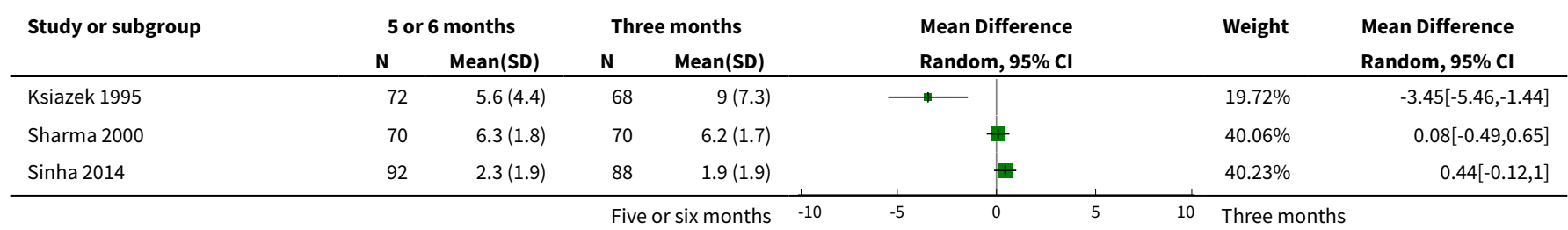




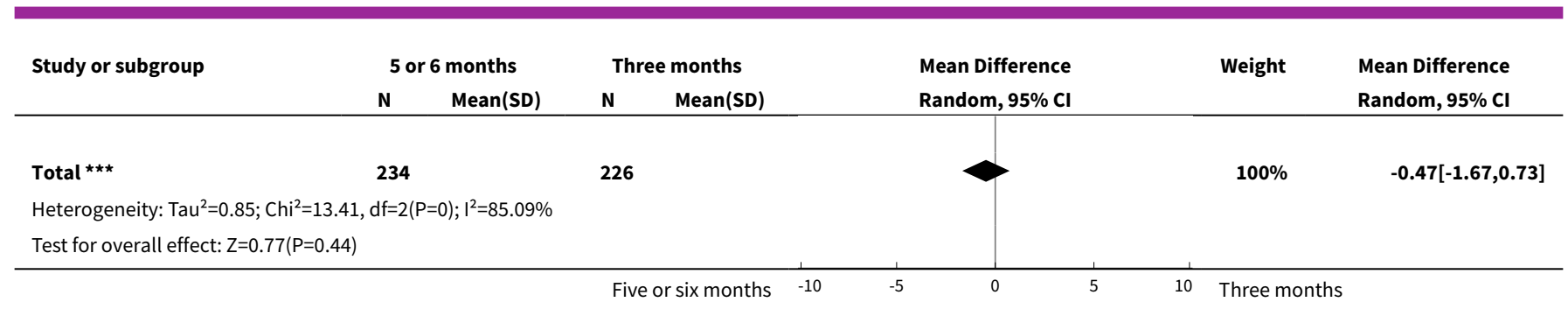

Analysis 2.5. Comparison 2 Steroid therapy in first episode of nephrotic syndrome: 5 or 6 months versus 3 months of therapy, Outcome 5 Number with frequent relapses stratified by definition of FRNS.

\begin{tabular}{|c|c|c|c|c|c|}
\hline Study or subgroup & $\begin{array}{c}5 \text { or } 6 \text { months } \\
n / N\end{array}$ & $\begin{array}{c}\text { Three months } \\
\mathbf{n} / \mathbf{N} \\
\end{array}$ & $\begin{array}{c}\text { Risk Ratio } \\
\text { M-H, Random, } 95 \% \text { Cl }\end{array}$ & Weight & $\begin{array}{c}\text { Risk Ratio } \\
\text { M-H, Random, } 95 \% \mathrm{Cl}\end{array}$ \\
\hline \multicolumn{6}{|c|}{ 2.5.1 FRNS by ISKDC definition } \\
\hline Hiraoka 2003 & $10 / 36$ & $15 / 34$ & - & $16.83 \%$ & $0.63[0.33,1.2]$ \\
\hline Sinha 2014 & $36 / 92$ & $35 / 89$ & & $38.73 \%$ & $1[0.69,1.43]$ \\
\hline Teeninga 2013 & $38 / 64$ & $31 / 62$ & & $44.44 \%$ & $1.19[0.86,1.64]$ \\
\hline Subtotal $(95 \% \mathrm{Cl})$ & 192 & 185 & & $100 \%$ & $1[0.74,1.34]$ \\
\hline \multicolumn{6}{|c|}{ Total events: 84 (5 or 6 months), 81 (Three months) } \\
\hline \multicolumn{6}{|c|}{ Heterogeneity: $\mathrm{Tau}^{2}=0.02 ; \mathrm{Chi}^{2}=3.06, \mathrm{df}=2(\mathrm{P}=0.22) ; \mathrm{I}^{2}=34.56 \%$} \\
\hline \multicolumn{6}{|c|}{ Test for overall effect: $\mathrm{Z}=0.02(\mathrm{P}=0.98)$} \\
\hline \multicolumn{6}{|c|}{ 2.5.2 Variation from ISKDC definition of FRNS } \\
\hline Mishra 2012 & $1 / 37$ & $1 / 37$ & & $6.63 \%$ & $1[0.06,15.4]$ \\
\hline Sharma 2000 & $8 / 70$ & $24 / 70$ & - & $93.37 \%$ & $0.33[0.16,0.69]$ \\
\hline \multicolumn{6}{|c|}{ Total events: 9 ( 5 or 6 months), 25 (Three months) } \\
\hline \multicolumn{6}{|c|}{ Heterogeneity: $\operatorname{Tau}^{2}=0 ; \mathrm{Chi}^{2}=0.58, \mathrm{df}=1(\mathrm{P}=0.45) ; \mathrm{I}^{2}=0 \%$} \\
\hline \multicolumn{6}{|c|}{ Test for overall effect: $Z=2.86(P=0)$} \\
\hline Test for subgroup dif & $.91, d f=1(P=0.01)$, & $85.52 \%$ & & & \\
\hline
\end{tabular}

Analysis 2.6. Comparison 2 Steroid therapy in first episode of nephrotic syndrome: 5 or 6 months versus 3 months of therapy, Outcome 6 Number with frequent relapses stratified by risk of bias for allocation concealment.

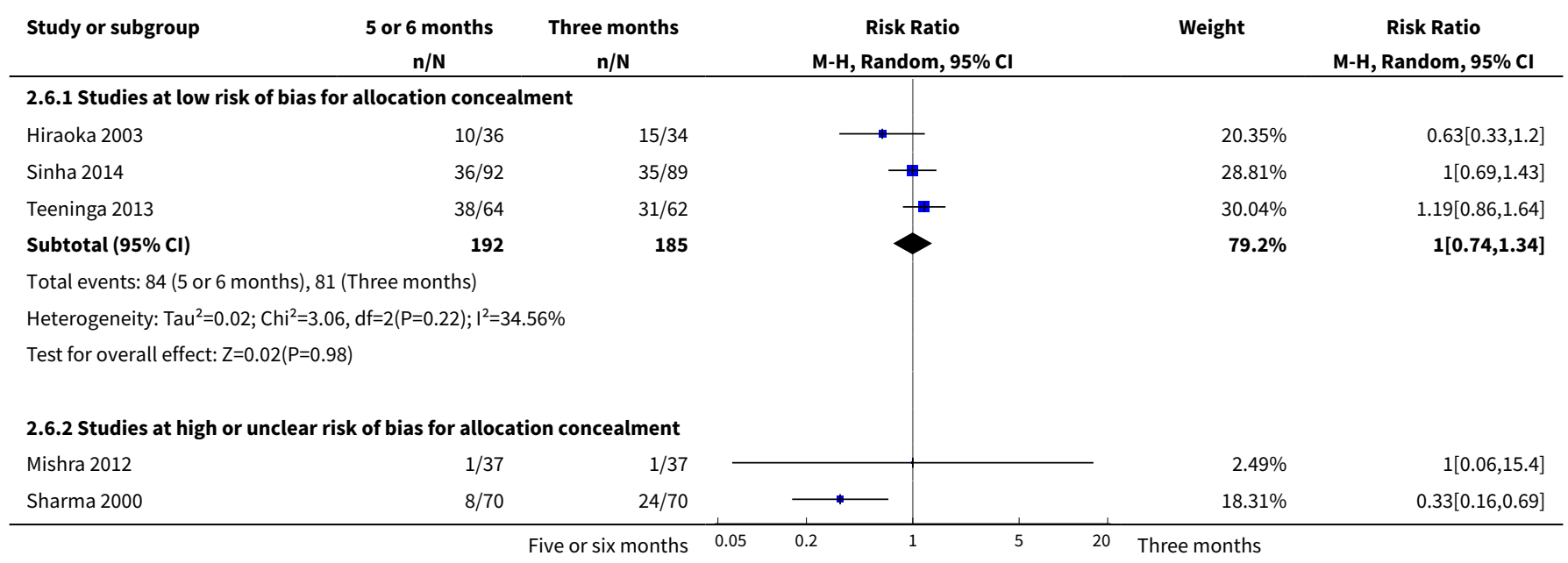




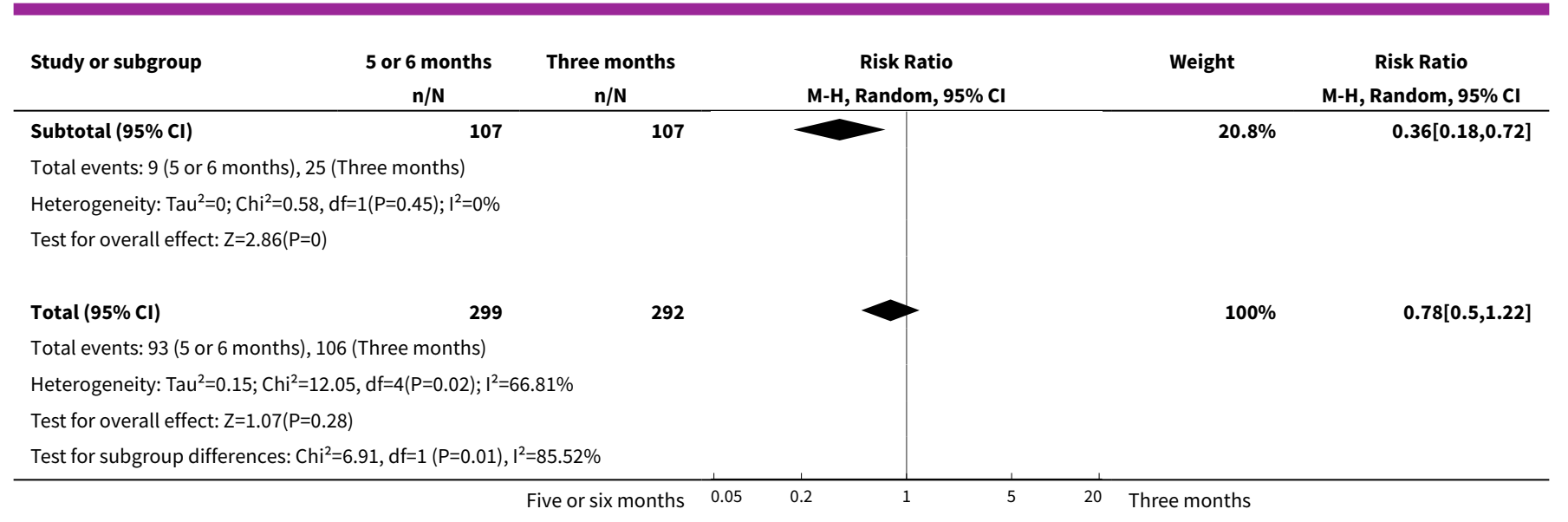

\section{Analysis 2.7. Comparison 2 Steroid therapy in first episode of nephrotic syndrome: 5 or 6 months versus} 3 months of therapy, Outcome 7 Number with frequent relapses stratified by risk of bias for blinding.

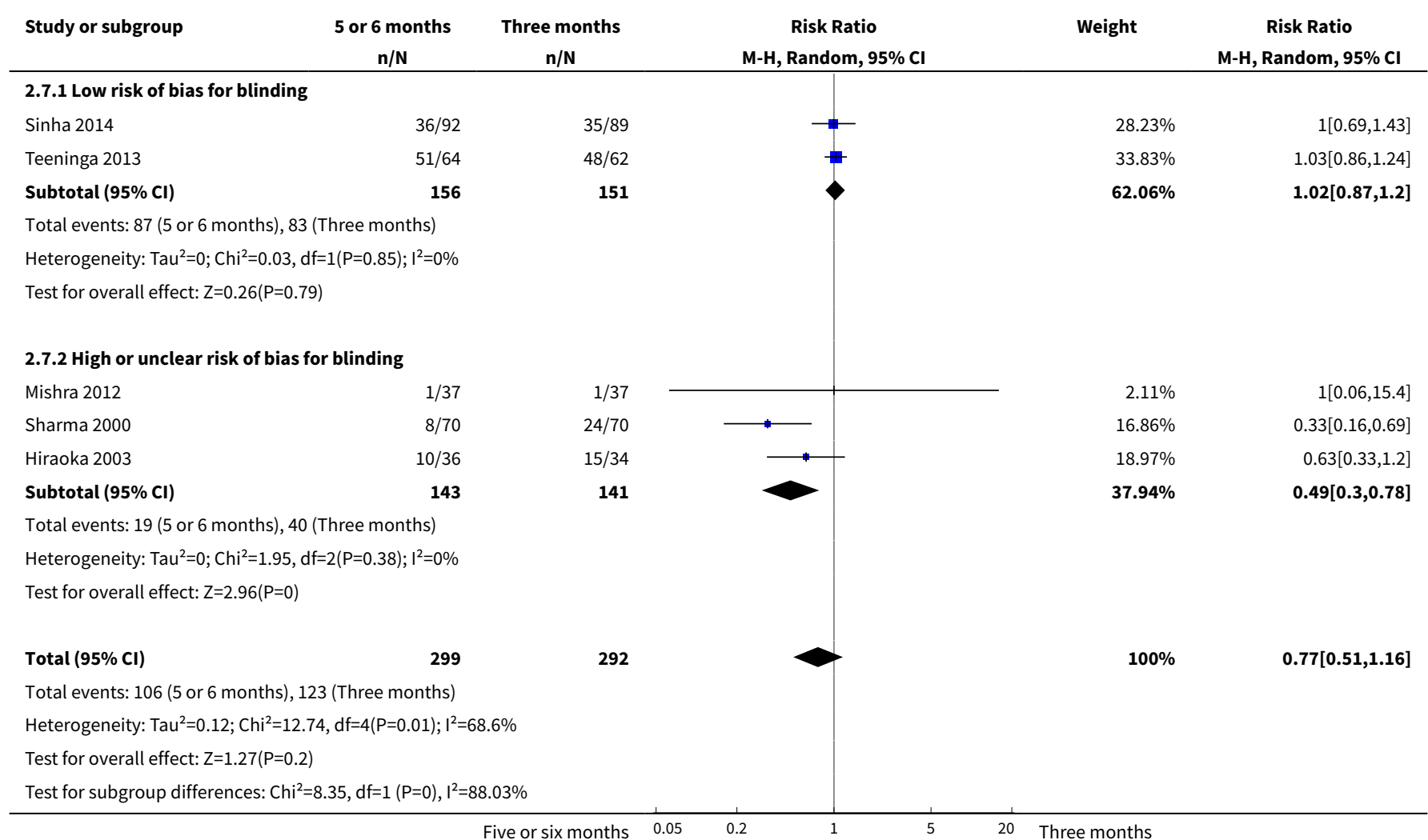

Analysis 2.8. Comparison 2 Steroid therapy in first episode of nephrotic syndrome: 5 or 6 months versus 3 months of therapy, Outcome 8 Number with frequent relapses stratified by risk of bias for attrition.

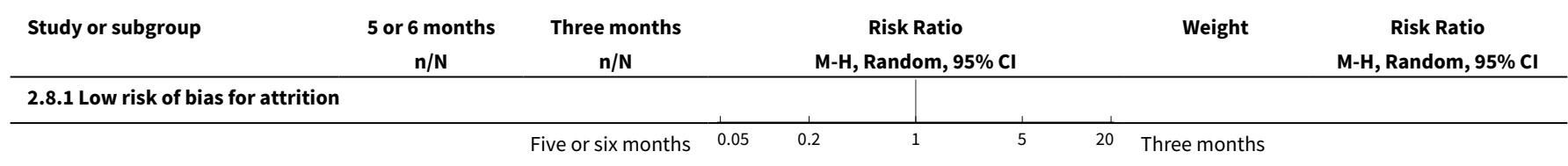




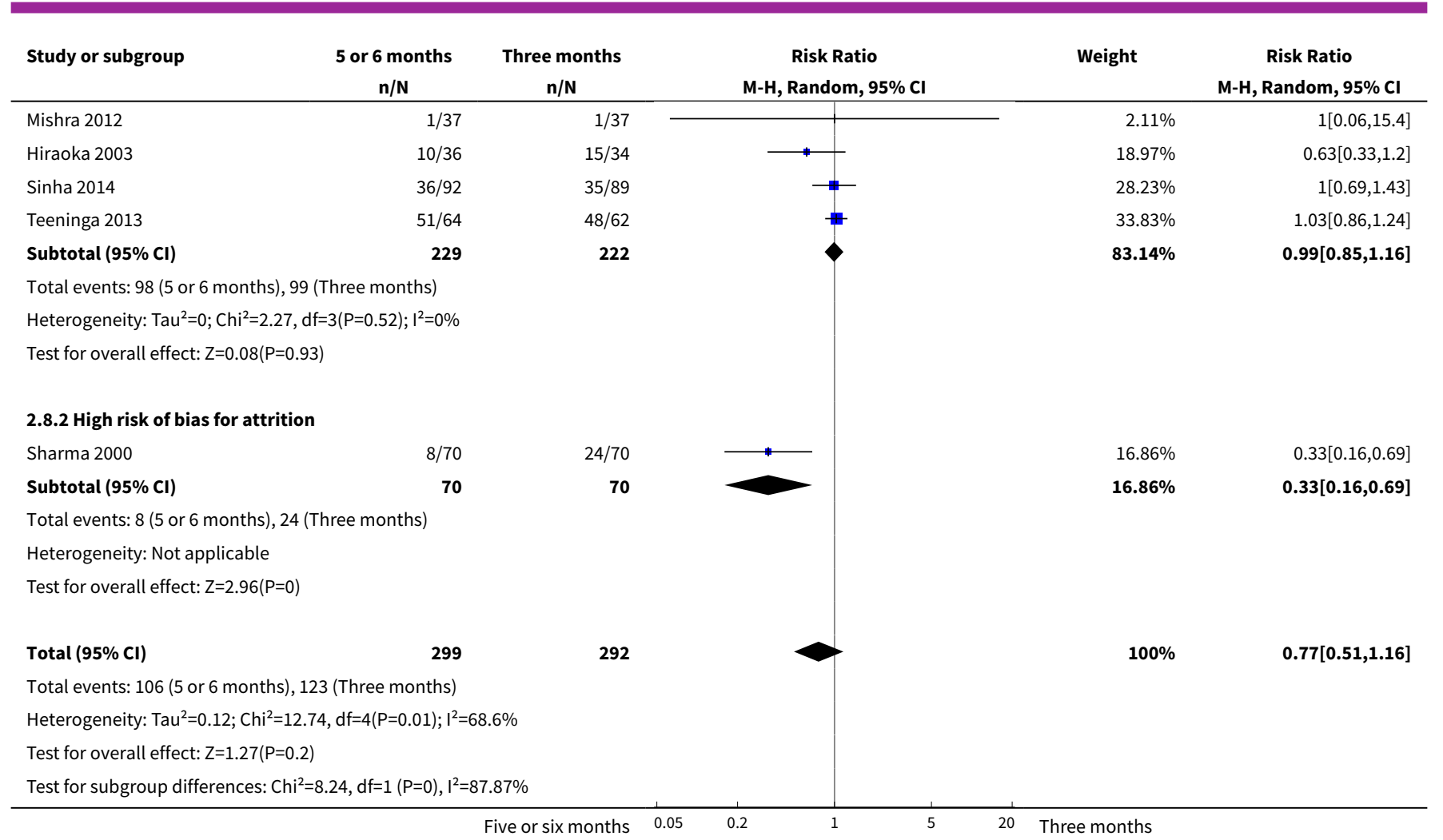

Analysis 2.9. Comparison 2 Steroid therapy in first episode of nephrotic syndrome: 5 or 6 months versus 3 months of therapy, Outcome 9 Adverse events.

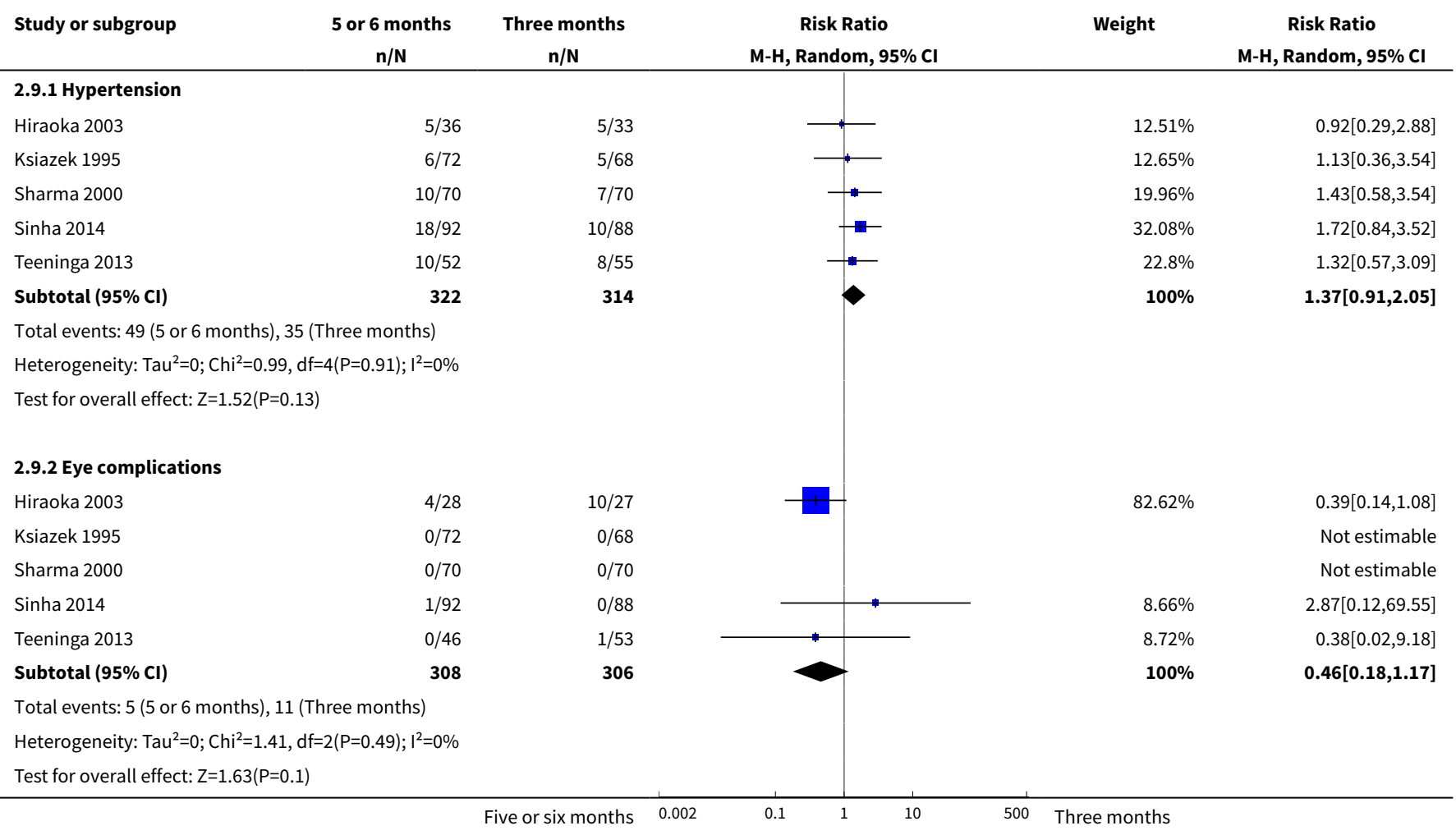




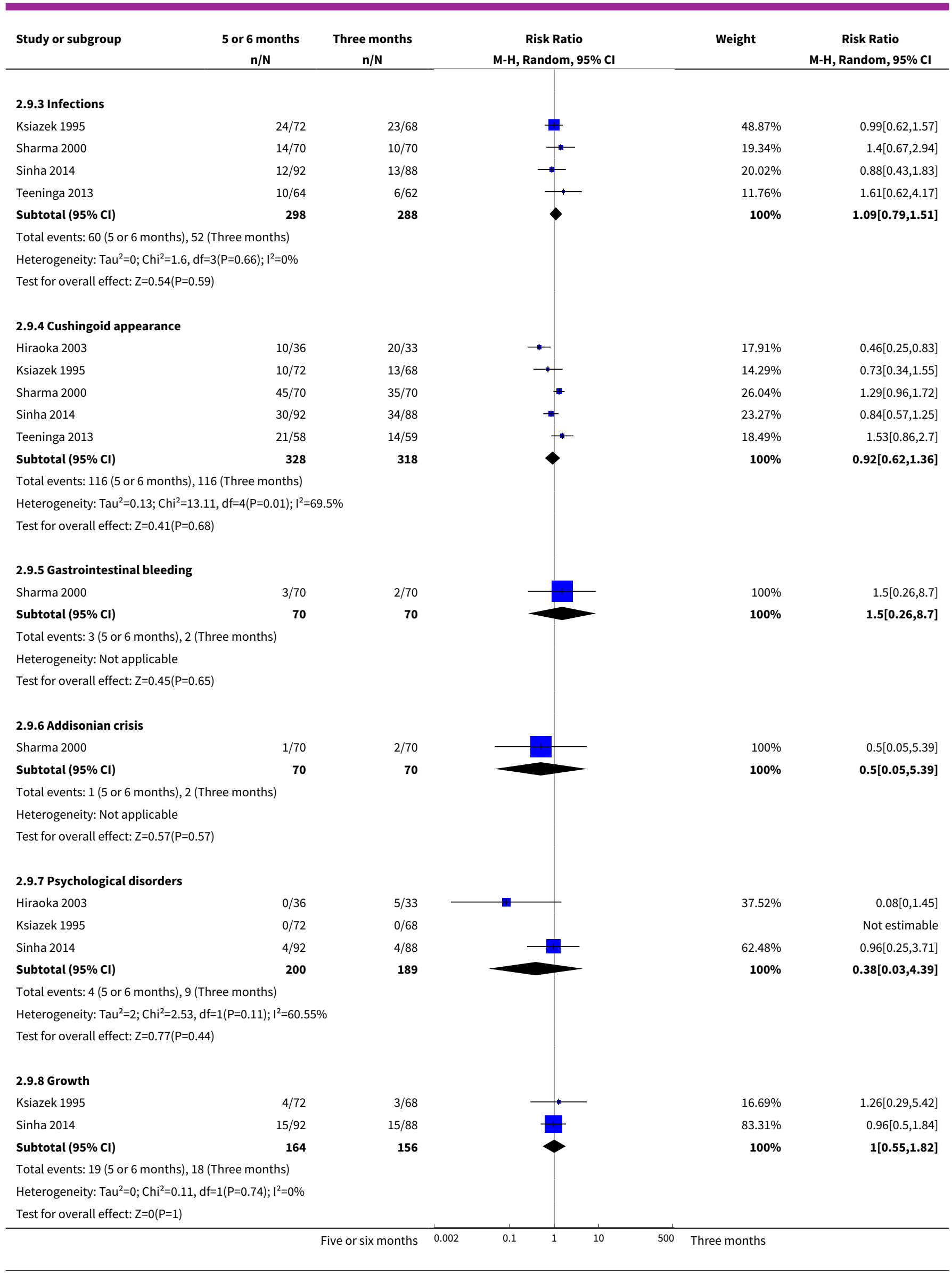


Comparison 3. Steroid therapy in the first episode of nephrotic syndrome: 1 month versus $\mathbf{2}$ months of therapy

\begin{tabular}{lllll}
\hline Outcome or subgroup title & $\begin{array}{l}\text { No. of } \\
\text { studies }\end{array}$ & $\begin{array}{l}\text { No. of } \\
\text { partici- } \\
\text { pants }\end{array}$ & Statistical method & Effect size \\
\hline $\begin{array}{l}1 \text { Number of children relapsing } \\
\text { by } 6 \text { months }\end{array}$ & 1 & Risk Ratio $(\mathrm{M}-\mathrm{H}$, Random, $95 \% \mathrm{Cl})$ & Totals not selected \\
\hline $\begin{array}{l}2 \text { Number of children relapsing } \\
\text { by } 12 \text { to } 24 \text { months }\end{array}$ & 1 & Risk Ratio $(\mathrm{M}-\mathrm{H}$, Random, $95 \% \mathrm{Cl})$ & Totals not selected \\
\hline $\begin{array}{l}3 \text { Number with frequent relaps- } \\
\text { es }\end{array}$ & 1 & Risk Ratio (M-H, Random, $95 \% \mathrm{Cl})$ & Totals not selected \\
\hline 4 Cumulative steroid dose & 1 & Mean Difference (IV, Random, $95 \% \mathrm{Cl})$ & Totals not selected
\end{tabular}

Analysis 3.1. Comparison 3 Steroid therapy in the first episode of nephrotic syndrome: 1 month versus 2 months of therapy, Outcome 1 Number of children relapsing by 6 months.

\begin{tabular}{|c|c|c|c|c|c|}
\hline Study or subgroup & $\begin{array}{c}1 \text { month } \\
\mathrm{n} / \mathrm{N}\end{array}$ & $\begin{array}{c}2 \text { months } \\
n / N\end{array}$ & M-H & $\begin{array}{l}\text { Ratio } \\
\text { lom, } 95 \% \mathrm{Cl}\end{array}$ & $\begin{array}{c}\text { Risk Ratio } \\
\text { M-H, Random, } 95 \% \mathrm{Cl}\end{array}$ \\
\hline APN 1988 & $23 / 32$ & $13 / 29$ & & 1 & $1.6[1.01,2.54]$ \\
\hline
\end{tabular}

Analysis 3.2. Comparison 3 Steroid therapy in the first episode of nephrotic syndrome: 1 month versus 2 months of therapy, Outcome 2 Number of children relapsing by 12 to 24 months.

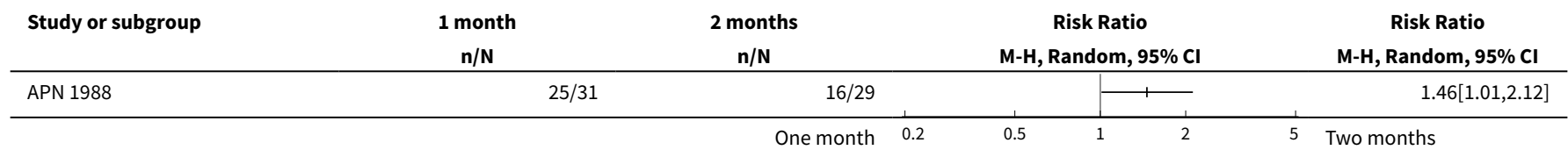

Analysis 3.3. Comparison 3 Steroid therapy in the first episode of nephrotic syndrome: 1 month versus 2 months of therapy, Outcome 3 Number with frequent relapses.

\begin{tabular}{|c|c|c|c|c|c|c|}
\hline Study or subgroup & $\begin{array}{c}1 \text { month } \\
n / N\end{array}$ & $\begin{array}{c}2 \text { months } \\
\mathrm{n} / \mathrm{N}\end{array}$ & & M-H & $\begin{array}{l}\text { k Ratio } \\
\text { dom, } 95 \% \mathrm{Cl}\end{array}$ & $\begin{array}{c}\text { Risk Ratio } \\
\text { M-H, Random, } 95 \% \mathrm{CI}\end{array}$ \\
\hline APN 1988 & $18 / 32$ & $11 / 29$ & & & 1,1 & $1.48[0.85,2.59]$ \\
\hline
\end{tabular}


Analysis 3.4. Comparison 3 Steroid therapy in the first episode of nephrotic syndrome: 1 month versus 2 months of therapy, Outcome 4 Cumulative steroid dose.

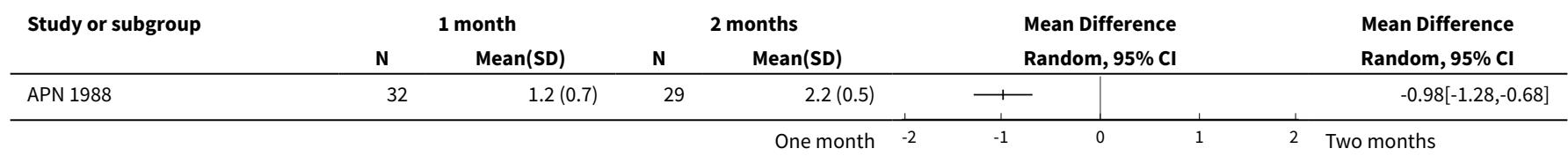

Comparison 4. Steroid therapy in the first episode of nephrotic syndrome: 12 months versus 5 months therapy

\begin{tabular}{lllll}
\hline Outcome or subgroup title & $\begin{array}{l}\text { No. of } \\
\text { studies }\end{array}$ & $\begin{array}{l}\text { No. of par- } \\
\text { ticipants }\end{array}$ & Statistical method & Effect size \\
\hline 1 Number with relapse & 1 & Risk Ratio (M-H, Random, 95\% Cl) & Totals not selected \\
\hline
\end{tabular}

Analysis 4.1. Comparison 4 Steroid therapy in the first episode of nephrotic syndrome: 12 months versus 5 months therapy, Outcome 1 Number with relapse.

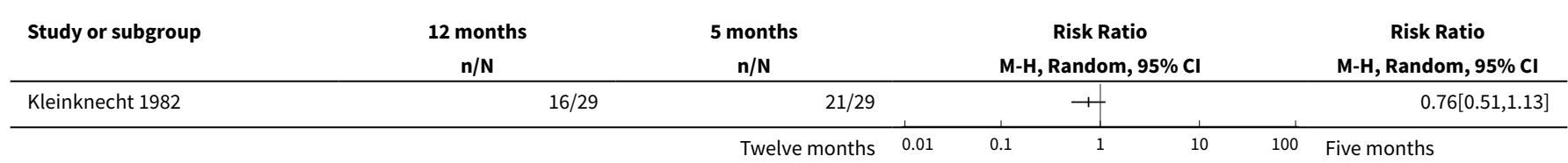

Comparison 5. Steroid therapy in the first episode of nephrotic syndrome: different total doses given over same duration

\begin{tabular}{|c|c|c|c|c|}
\hline Outcome or subgroup title & $\begin{array}{l}\text { No. of } \\
\text { studies }\end{array}$ & $\begin{array}{l}\text { No. of } \\
\text { partici- } \\
\text { pants }\end{array}$ & Statistical method & Effect size \\
\hline 1 Relapse at twelve months & 1 & & $\begin{array}{l}\text { Risk Ratio (M-H, Random, 95\% } \\
\mathrm{Cl})\end{array}$ & Totals not selected \\
\hline $\begin{array}{l}2 \text { Number with frequently relapsing } \\
\text { nephrotic syndrome }\end{array}$ & 1 & & $\begin{array}{l}\text { Risk Ratio (M-H, Random, 95\% } \\
\mathrm{Cl})\end{array}$ & Totals not selected \\
\hline 3 Adverse effects & 1 & & $\begin{array}{l}\text { Risk Ratio (M-H, Random, 95\% } \\
\mathrm{Cl})\end{array}$ & Totals not selected \\
\hline 3.1 Hypertension & 1 & & $\begin{array}{l}\text { Risk Ratio (M-H, Random, 95\% } \\
\mathrm{Cl})\end{array}$ & $0.0[0.0,0.0]$ \\
\hline 3.2 Psychological disorders & 1 & & $\begin{array}{l}\text { Risk Ratio (M-H, Random, 95\% } \\
\mathrm{Cl})\end{array}$ & $0.0[0.0,0.0]$ \\
\hline 3.3 Cushing's Syndrome & 1 & & $\begin{array}{l}\text { Risk Ratio (M-H, Random, 95\% } \\
\mathrm{Cl})\end{array}$ & $0.0[0.0,0.0]$ \\
\hline
\end{tabular}


Analysis 5.1. Comparison 5 Steroid therapy in the first episode of nephrotic syndrome: different total doses given over same duration, Outcome 1 Relapse at twelve months.

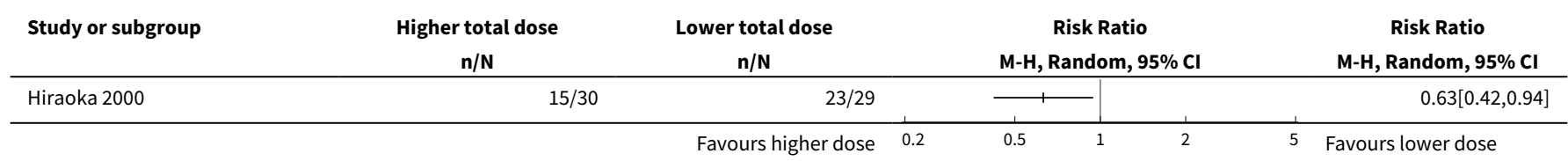

Analysis 5.2. Comparison 5 Steroid therapy in the first episode of nephrotic syndrome: different total doses given over same duration, Outcome 2 Number with frequently relapsing nephrotic syndrome.

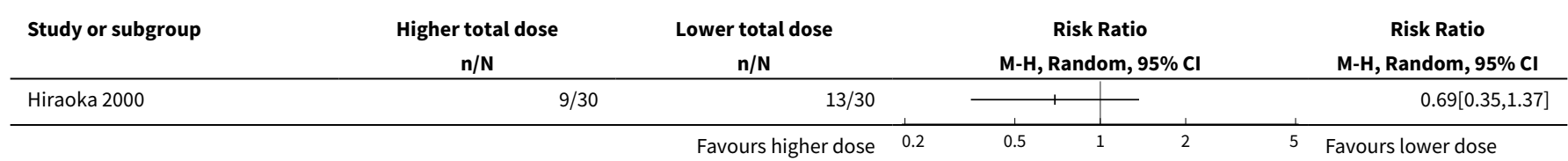

Analysis 5.3. Comparison 5 Steroid therapy in the first episode of nephrotic syndrome: different total doses given over same duration, Outcome 3 Adverse effects.

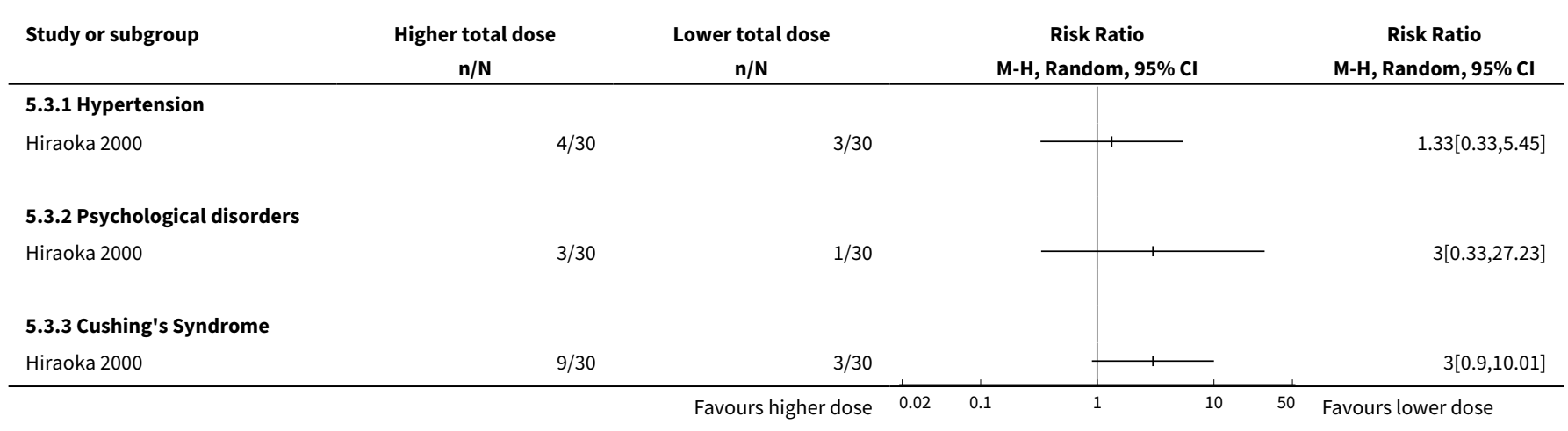

\section{Comparison 6. Steroid therapy and Sairei-to in first episode of nephrotic syndrome}

\begin{tabular}{|c|c|c|c|c|}
\hline Outcome or subgroup title & $\begin{array}{l}\text { No. of } \\
\text { studies }\end{array}$ & $\begin{array}{l}\text { No. of } \\
\text { partici- } \\
\text { pants }\end{array}$ & Statistical method & Effect size \\
\hline $\begin{array}{l}1 \text { Long prednisone \& Sairei-to versus } \\
\text { standard prednisone \& Sairei-to }\end{array}$ & 1 & & Risk Ratio (M-H, Random, 95\% Cl) & $\begin{array}{l}\text { Totals not select- } \\
\text { ed }\end{array}$ \\
\hline 1.1 Relapse at 2 years & 1 & & Risk Ratio (M-H, Random, 95\% Cl) & $0.0[0.0,0.0]$ \\
\hline $\begin{array}{l}1.2 \text { Number with frequent relapses at } 2 \\
\text { years }\end{array}$ & 1 & & Risk Ratio (M-H, Random, 95\% Cl) & $0.0[0.0,0.0]$ \\
\hline
\end{tabular}


Analysis 6.1. Comparison 6 Steroid therapy and Sairei-to in first episode of nephrotic syndrome, Outcome 1 Long prednisone \& Sairei-to versus standard prednisone \& Sairei-to.

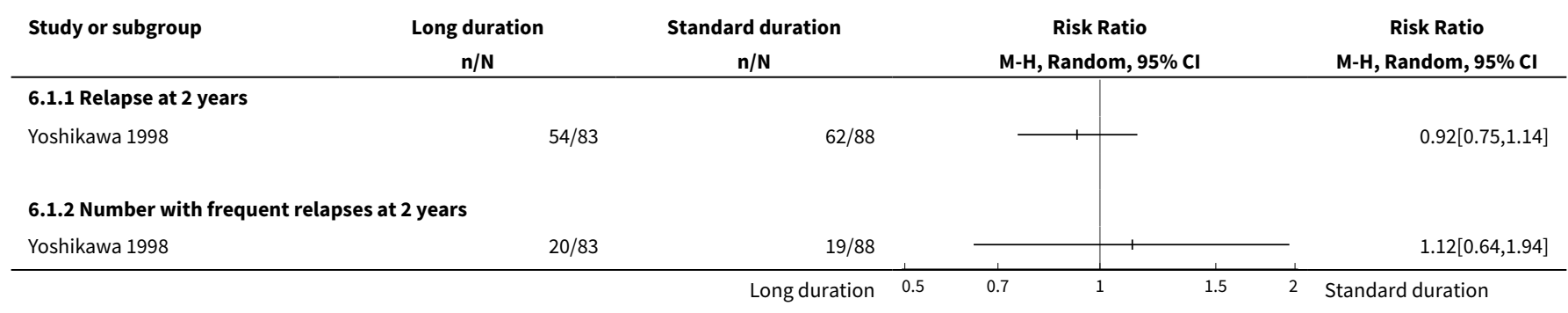

Comparison 7. Cyclosporin (CSA) and steroid therapy in first episode of childhood nephrotic syndrome

\begin{tabular}{lllll}
\hline Outcome or subgroup title & $\begin{array}{l}\text { No. of } \\
\text { studies }\end{array}$ & $\begin{array}{l}\text { No. of } \\
\text { partici- } \\
\text { pants }\end{array}$ & Statistical method & Effect size \\
\hline 1 Relapse by 6 months & 1 & $\begin{array}{l}\text { Risk Ratio (M-H, Random, 95\% } \\
\mathrm{Cl})\end{array}$ & Totals not selected \\
\hline 2 Relapse by 12 months & 1 & $\begin{array}{l}\text { Risk Ratio (M-H, Random, 95\% } \\
\mathrm{Cl})\end{array}$ & Totals not selected \\
\hline 3 Number needing cytotoxic agents & 1 & $\begin{array}{l}\text { Risk Ratio (M-H, Random, 95\% } \\
\mathrm{Cl})\end{array}$ & Totals not selected \\
\hline 4 Serum creatinine at end of study & 1 & $\begin{array}{l}\text { Mean Difference (IV, Random, } \\
95 \% \mathrm{Cl})\end{array}$ & Totals not selected \\
\hline
\end{tabular}

Analysis 7.1. Comparison 7 Cyclosporin (CSA) and steroid therapy in first episode of childhood nephrotic syndrome, Outcome 1 Relapse by 6 months.

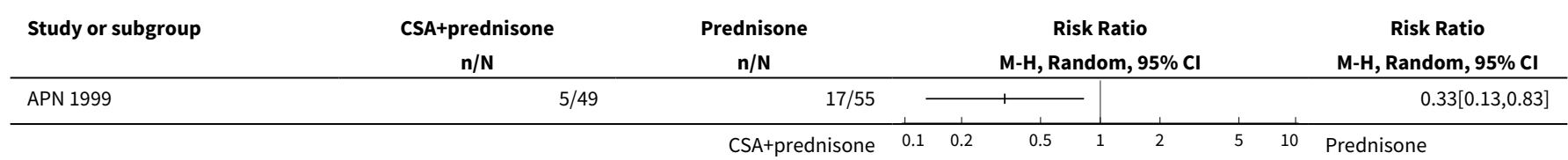

Analysis 7.2. Comparison 7 Cyclosporin (CSA) and steroid therapy in first episode of childhood nephrotic syndrome, Outcome 2 Relapse by 12 months.

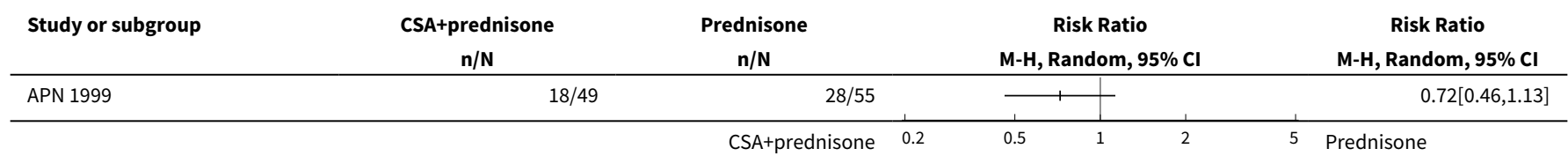


Analysis 7.3. Comparison 7 Cyclosporin (CSA) and steroid therapy in first episode of childhood nephrotic syndrome, Outcome 3 Number needing cytotoxic agents.

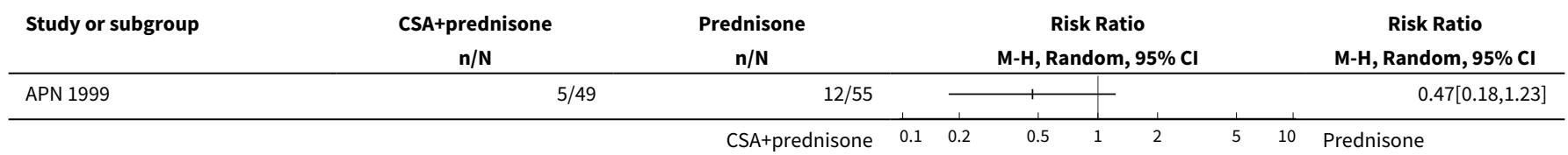

Analysis 7.4. Comparison 7 Cyclosporin (CSA) and steroid therapy in first episode of childhood nephrotic syndrome, Outcome 4 Serum creatinine at end of study.

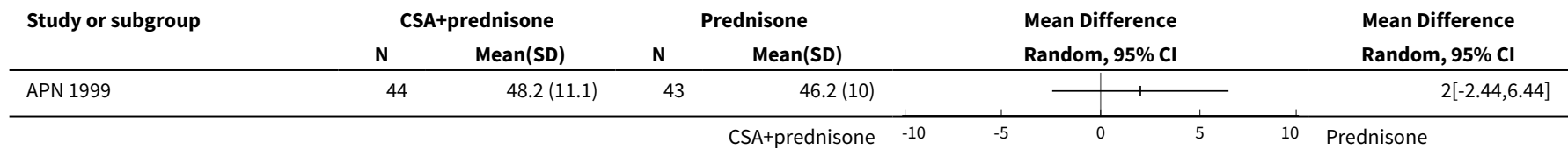

Comparison 8. Steroid therapy in first episode of nephrotic syndrome: high dose methylprednisone versus 2 month therapy

\begin{tabular}{lllll}
\hline Outcome or subgroup title & $\begin{array}{l}\text { No. of } \\
\text { studies }\end{array}$ & $\begin{array}{l}\text { No. of } \\
\text { partici- } \\
\text { pants }\end{array}$ & Statistical method & Effect size \\
\hline 1 Time to first relapse & 1 & Mean Difference (IV, Random, 95\% Cl) & Totals not selected \\
\hline 2 Relapse rate & 1 & Mean Difference (IV, Random, 95\% Cl) & Totals not selected \\
\hline 3 Time to remission & 1 & Mean Difference (IV, Random, 95\% Cl) & Totals not selected \\
\hline
\end{tabular}

Analysis 8.1. Comparison 8 Steroid therapy in first episode of nephrotic syndrome: high dose methylprednisone versus 2 month therapy, Outcome 1 Time to first relapse.

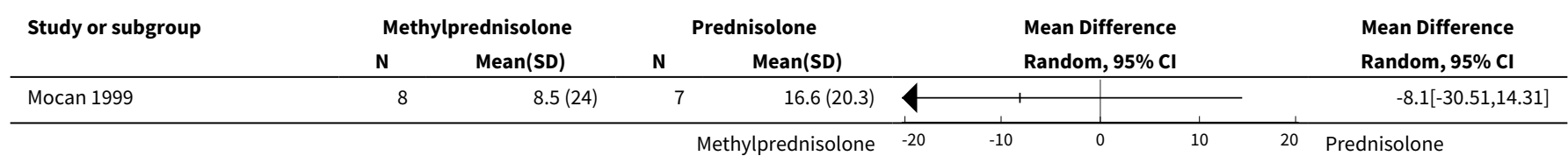

Analysis 8.2. Comparison 8 Steroid therapy in first episode of nephrotic syndrome: high dose methylprednisone versus 2 month therapy, Outcome 2 Relapse rate.

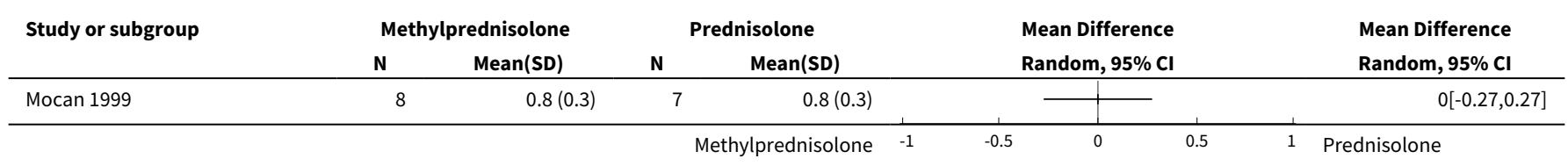


Analysis 8.3. Comparison 8 Steroid therapy in first episode of nephrotic syndrome: high dose methylprednisone versus 2 month therapy, Outcome 3 Time to remission.

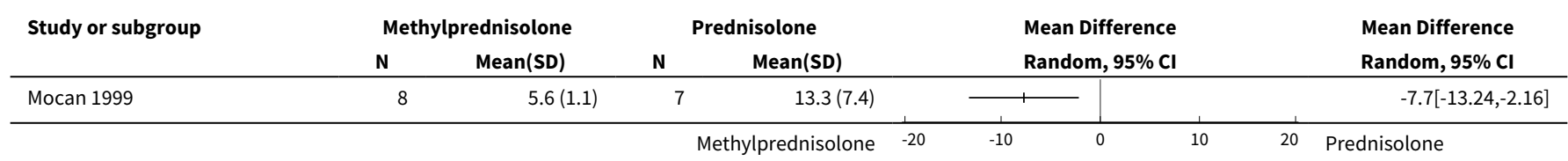

\section{Comparison 9. Steroid therapy and azithromycin (AZM) in the first episode of nephrotic syndrome}

\begin{tabular}{lllll}
\hline Outcome or subgroup title & $\begin{array}{l}\text { No. of } \\
\text { studies }\end{array}$ & $\begin{array}{l}\text { No. of par- } \\
\text { ticipants }\end{array}$ & Statistical method & Effect size \\
\hline $\begin{array}{l}1 \text { Number of children relapsing by } 6 \\
\text { months }\end{array}$ & 1 & Risk Ratio (M-H, Random, 95\% Cl) & Totals not selected
\end{tabular}

Analysis 9.1. Comparison 9 Steroid therapy and azithromycin (AZM) in the first episode of nephrotic syndrome, Outcome 1 Number of children relapsing by 6 months.

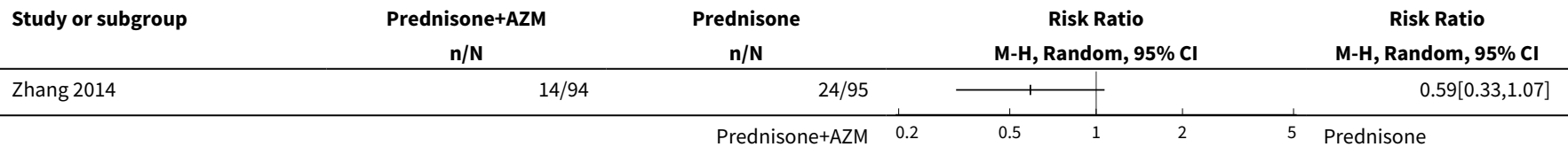

Comparison 10. Daily prednisolone treatment during viral infections

\begin{tabular}{lllll}
\hline Outcome or subgroup title & $\begin{array}{l}\text { No. of } \\
\text { studies }\end{array}$ & $\begin{array}{l}\text { No. of } \\
\text { partici- } \\
\text { pants }\end{array}$ & Statistical method & Effect size \\
\hline $\begin{array}{l}1 \text { Number with relapse with infec- } \\
\text { tion }\end{array}$ & 1 & Risk Ratio (M-H, Random, 95\% CI) & Totals not selected \\
\hline $\begin{array}{l}\text { 2 Number of relapses/patient } \\
\text { 2.1 Number of infection-related re- } \\
\text { lapses/patient/year }\end{array}$ & 1 & Mean Difference (IV, Random, 95\% Cl) & Totals not selected \\
\hline $\begin{array}{l}\text { 2.2 Total relapses (episodes/pa- } \\
\text { tient/1 year) }\end{array}$ & 1 & Mean Difference (IV, Random, 95\% Cl) & $0.0[0.0,0.0]$ \\
\hline $\begin{array}{l}\text { 3 Number of relapses/patient at 2 } \\
\text { years }\end{array}$ & 1 & Mean Difference (IV, Random, 95\% Cl) & $0.0[0.0,0.0]$ \\
\hline
\end{tabular}


Analysis 10.1. Comparison 10 Daily prednisolone treatment during viral infections, Outcome 1 Number with relapse with infection.

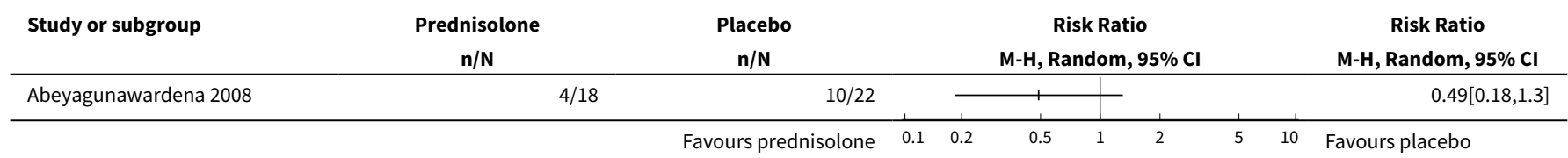

Analysis 10.2. Comparison 10 Daily prednisolone treatment during viral infections, Outcome 2 Number of relapses/patient.

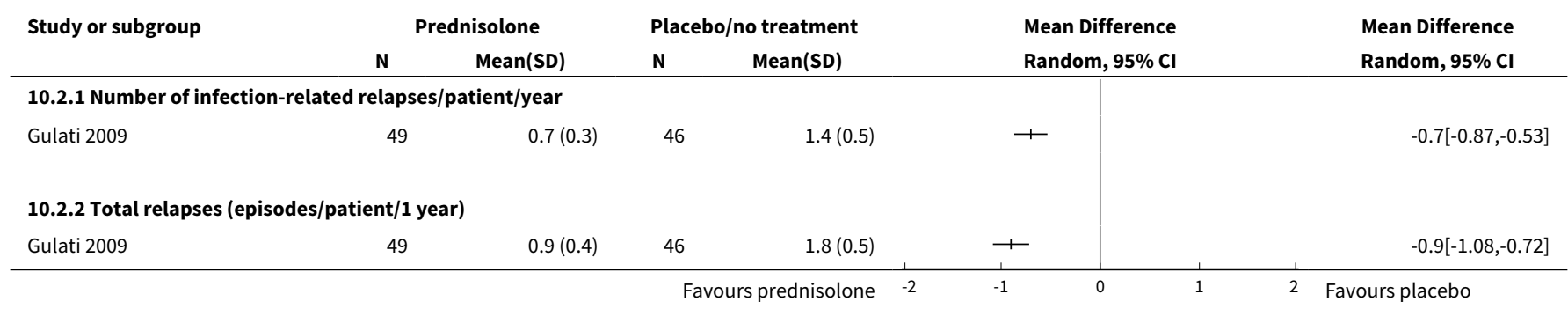

Analysis 10.3. Comparison 10 Daily prednisolone treatment during viral infections, Outcome 3 Number of relapses/patient at 2 years.

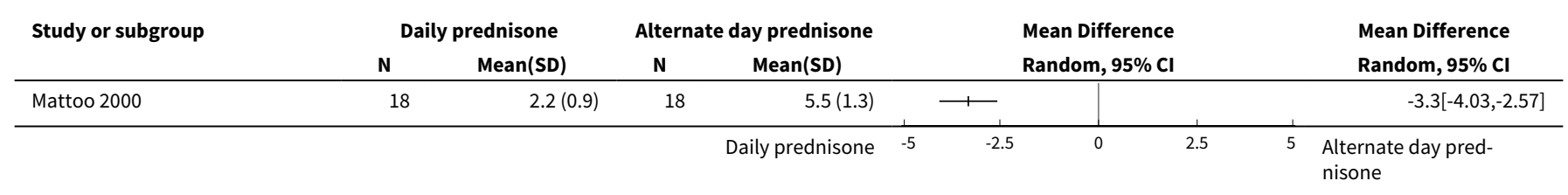

Comparison 11. Steroid therapy in relapse of nephrotic syndrome

\begin{tabular}{lllll}
\hline Outcome or subgroup title & $\begin{array}{l}\text { No. of } \\
\text { studies }\end{array}$ & $\begin{array}{l}\text { No. of } \\
\text { partici- } \\
\text { pants }\end{array}$ & Statistical method & Effect size \\
\hline $\begin{array}{l}1 \text { Number of children relapsing during } \\
\text { therapy }\end{array}$ & 2 & Risk Ratio (M-H, Random, 95\% Cl) & $\begin{array}{l}\text { Totals not select- } \\
\text { ed }\end{array}$ \\
\hline $\begin{array}{l}1.1 \text { Intermittent dose versus alter- } \\
\text { nate-day therapy (6 months therapy) }\end{array}$ & 1 & Risk Ratio (M-H, Random, 95\% Cl) & $0.0[0.0,0.0]$ \\
\hline $\begin{array}{l}1.2 \text { Daily versus intermittent therapy }(2 \\
\text { months therapy) }\end{array}$ & 1 & Risk Ratio (M-H, Random, 95\% Cl) & $0.0[0.0,0.0]$ \\
\hline $\begin{array}{l}2 \text { Number of children with further re- } \\
\text { lapses by } 9 \text { to } 12 \text { months }\end{array}$ & 5 & Risk Ratio (M-H, Random, 95\% Cl) & Totals not select- \\
\hline $\begin{array}{l}2.1 \text { Intermittent dose versus alter- } \\
\text { nate-day therapy (6 months therapy) }\end{array}$ & 1 & Risk Ratio (M-H, Random, 95\% Cl) & $0.0[0.0,0.0]$ \\
\hline
\end{tabular}




\begin{tabular}{|c|c|c|c|c|}
\hline Outcome or subgroup title & $\begin{array}{l}\text { No. of } \\
\text { studies }\end{array}$ & $\begin{array}{l}\text { No. of } \\
\text { partici- } \\
\text { pants }\end{array}$ & Statistical method & Effect size \\
\hline $\begin{array}{l}2.2 \text { Single versus divided dose therapy } \\
(2 \text { months therapy) }\end{array}$ & 1 & & Risk Ratio (M-H, Random, 95\% Cl) & $0.0[0.0,0.0]$ \\
\hline $\begin{array}{l}2.3 \text { Intravenous versus oral therapy ( } 6 \\
\text { months therapy) }\end{array}$ & 1 & & Risk Ratio (M-H, Random, 95\% Cl) & $0.0[0.0,0.0]$ \\
\hline $\begin{array}{l}\text { 2.4 Deflazacort versus prednisone ( } 12 \\
\text { months therapy) }\end{array}$ & 1 & & Risk Ratio (M-H, Random, 95\% Cl) & $0.0[0.0,0.0]$ \\
\hline $\begin{array}{l}2.5 \text { Prolonged oral versus intermittent } \\
\text { therapy ( } 2 \text { months therapy ) }\end{array}$ & 1 & & Risk Ratio (M-H, Random, 95\% Cl) & $0.0[0.0,0.0]$ \\
\hline 3 Mean relapse rate/patient/y & 3 & & Mean Difference (IV, Random, 95\% CI) & $\begin{array}{l}\text { Totals not select- } \\
\text { ed }\end{array}$ \\
\hline $\begin{array}{l}\text { 3.1 Single versus divided dose therapy } \\
(2 \text { months therapy) }\end{array}$ & 1 & & Mean Difference (IV, Random, 95\% CI) & $0.0[0.0,0.0]$ \\
\hline $\begin{array}{l}\text { 3.2 Daily versus intermittent therapy ( } 2 \\
\text { months therapy) }\end{array}$ & 1 & & Mean Difference (IV, Random, 95\% CI) & $0.0[0.0,0.0]$ \\
\hline $\begin{array}{l}\text { 3.3 Deflazacort versus prednisone ( } 12 \\
\text { months therapy) }\end{array}$ & 1 & & Mean Difference (IV, Random, 95\% CI) & $0.0[0.0,0.0]$ \\
\hline 4 Mean time to relapse & 2 & & Mean Difference (IV, Random, 95\% CI) & $\begin{array}{l}\text { Totals not select- } \\
\text { ed }\end{array}$ \\
\hline $\begin{array}{l}\text { 4.1 Single versus divided dose therapy } \\
(2 \text { months therapy) }\end{array}$ & 1 & & Mean Difference (IV, Random, 95\% CI) & $0.0[0.0,0.0]$ \\
\hline $\begin{array}{l}4.2 \text { Daily versus intermittent therapy ( } 2 \\
\text { months therapy) }\end{array}$ & 1 & & Mean Difference (IV, Random, 95\% CI) & $0.0[0.0,0.0]$ \\
\hline 5 Cumulative steroid dose & 1 & & Mean Difference (IV, Random, 95\% Cl) & $\begin{array}{l}\text { Totals not select- } \\
\text { ed }\end{array}$ \\
\hline 6 Mean time to remission & 2 & 138 & Mean Difference (IV, Random, 95\% CI) & $0.04[-0.98,1.06]$ \\
\hline 7 Serious adverse events & 2 & 138 & Risk Ratio (M-H, Random, 95\% Cl) & $0.41[0.18,0.91]$ \\
\hline
\end{tabular}

\section{Analysis 11.1. Comparison 11 Steroid therapy in relapse of nephrotic} syndrome, Outcome 1 Number of children relapsing during therapy.

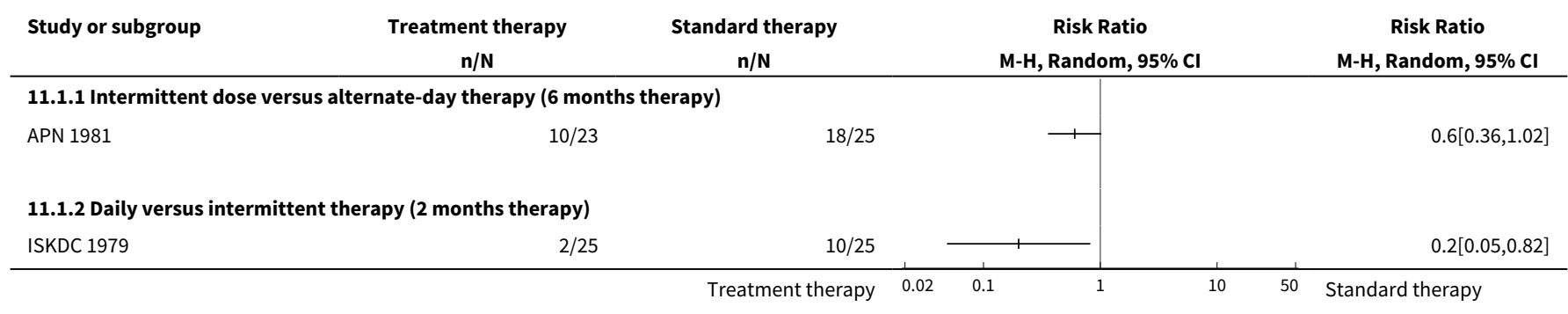


Analysis 11.2. Comparison 11 Steroid therapy in relapse of nephrotic syndrome, Outcome 2 Number of children with further relapses by 9 to 12 months.

\begin{tabular}{|c|c|c|c|c|}
\hline Study or subgroup & $\begin{array}{c}\text { Treatment therapy } \\
\mathrm{n} / \mathrm{N}\end{array}$ & $\begin{array}{c}\text { Standard therapy } \\
n / N\end{array}$ & $\begin{array}{c}\text { Risk Ratio } \\
\text { M-H, Random, } 95 \% \mathrm{Cl} \\
\end{array}$ & \multirow[t]{2}{*}{$\begin{array}{c}\text { Risk Ratio } \\
\text { M-H, Random, } 95 \% \mathrm{CI} \\
\end{array}$} \\
\hline 11.2.1 Intermittent & nate-day therapy (6 mont & erapy) & & \\
\hline APN 1981 & $21 / 23$ & $19 / 25$ & & $1.2[0.93,1.55]$ \\
\hline \multicolumn{5}{|c|}{ 11.2.2 Single versus divided dose therapy ( 2 months therapy) } \\
\hline Ekka 1997 & $29 / 47$ & $27 / 47$ & & $1.07[0.77,1.5]$ \\
\hline \multicolumn{5}{|c|}{ 11.2.3 Intravenous versus oral therapy (6 months therapy) } \\
\hline Imbasciati 1985 & $21 / 31$ & $21 / 33$ & & $1.06[0.75,1.52]$ \\
\hline \multicolumn{5}{|c|}{ 11.2.4 Deflazacort versus prednisone (12 months therapy) } \\
\hline Broyer 1997 & $8 / 20$ & $18 / 20$ & & $0.44[0.25,0.78]$ \\
\hline \multicolumn{5}{|c|}{ 11.2.5 Prolonged oral versus intermittent therapy ( 2 months therapy) } \\
\hline ISKDC 1979 & $24 / 25$ & $24 / 25$ & + & $1[0.89,1.12]$ \\
\hline
\end{tabular}

Analysis 11.3. Comparison 11 Steroid therapy in relapse of nephrotic syndrome, Outcome 3 Mean relapse rate/patient/y.

\begin{tabular}{|c|c|c|c|c|c|c|}
\hline \multirow[t]{2}{*}{ Study or subgroup } & \multicolumn{2}{|c|}{ Treatment therapy } & \multicolumn{2}{|c|}{ Standard therapy } & \multirow{2}{*}{$\begin{array}{l}\text { Mean Difference } \\
\text { Random, } 95 \% \mathrm{Cl}\end{array}$} & \multirow{2}{*}{$\begin{array}{l}\text { Mean Difference } \\
\text { Random, } 95 \% \mathrm{CI}\end{array}$} \\
\hline & $\mathbf{N}$ & Mean(SD) & $\mathbf{N}$ & Mean(SD) & & \\
\hline \multicolumn{7}{|c|}{ 11.3.1 Single versus divided dose therapy ( 2 months therapy) } \\
\hline Ekka 1997 & 47 & $1.7(1.1)$ & 47 & $1.9(1.1)$ & $一$ & $-0.2[-0.64,0.24]$ \\
\hline \multicolumn{7}{|c|}{ 11.3.2 Daily versus intermittent therapy ( 2 months therapy) } \\
\hline ISKDC 1979 & 25 & $3.8(2.2)$ & 25 & $3.3(1.5)$ & -1, & $0.54[-0.5,1.58]$ \\
\hline \multicolumn{7}{|c|}{ 11.3.3 Deflazacort versus prednisone (12 months therapy) } \\
\hline Broyer 1997 & 20 & $0.9(1.4)$ & 20 & $2.8(1.4)$ & 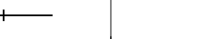 & $-1.9[-2.77,-1.03]$ \\
\hline
\end{tabular}

Analysis 11.4. Comparison 11 Steroid therapy in relapse of nephrotic syndrome, Outcome 4 Mean time to relapse.

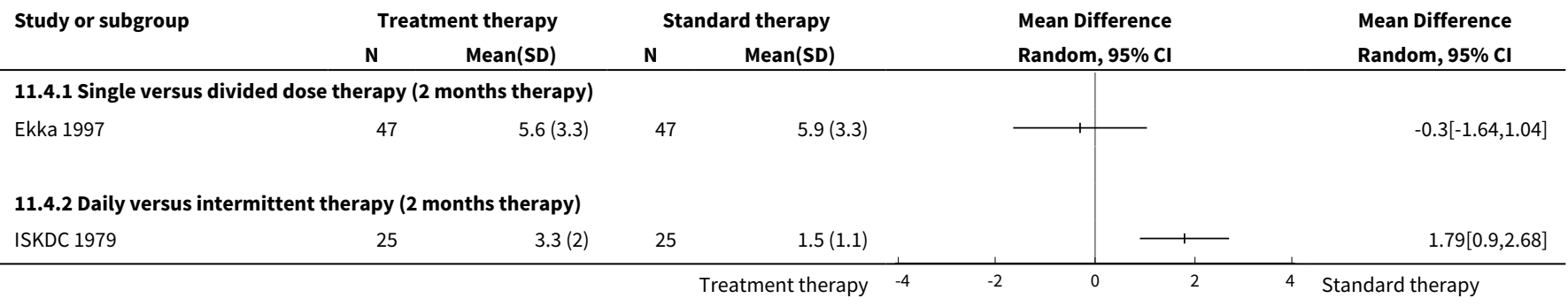


Analysis 11.5. Comparison 11 Steroid therapy in relapse of nephrotic syndrome, Outcome 5 Cumulative steroid dose.

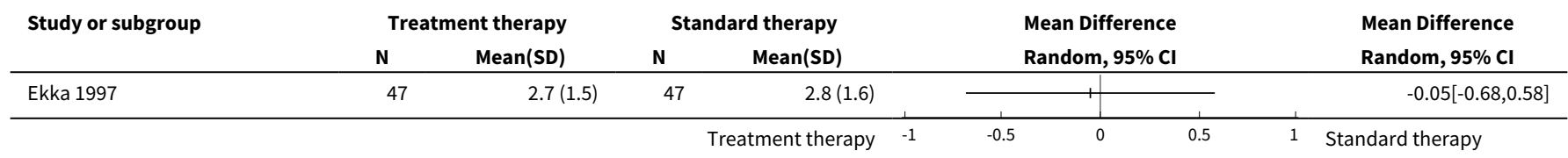

Analysis 11.6. Comparison 11 Steroid therapy in relapse of nephrotic syndrome, Outcome 6 Mean time to remission.

\begin{tabular}{|c|c|c|c|c|c|c|c|}
\hline \multirow[t]{2}{*}{ Study or subgroup } & \multicolumn{2}{|c|}{ Treatment therapy } & \multicolumn{2}{|c|}{ Standard therapy } & \multirow{2}{*}{$\begin{array}{l}\text { Mean Difference } \\
\text { Random, 95\% Cl }\end{array}$} & \multirow[t]{2}{*}{ Weight } & \multirow{2}{*}{$\begin{array}{l}\text { Mean Difference } \\
\text { Random, } 95 \% \mathrm{Cl}\end{array}$} \\
\hline & $\mathbf{N}$ & Mean(SD) & $\mathbf{N}$ & Mean(SD) & & & \\
\hline Ekka 1997 & 47 & $8.6(2.8)$ & 47 & $8.5(2.9)$ & - & $78.88 \%$ & $0.1[-1.05,1.25]$ \\
\hline Li 1994 & 19 & $10.8(3.6)$ & 25 & $11(3.9)$ & 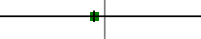 & $21.12 \%$ & $-0.19[-2.42,2.04]$ \\
\hline 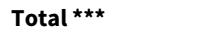 & 66 & & 72 & & & $100 \%$ & $0.04[-0.98,1.06]$ \\
\hline \multicolumn{8}{|c|}{ Heterogeneity: $\operatorname{Tau}^{2}=0 ; \mathrm{Chi}^{2}=0.05, \mathrm{df}=1(\mathrm{P}=0.82) ; \mathrm{I}^{2}=0 \%$} \\
\hline
\end{tabular}

Analysis 11.7. Comparison 11 Steroid therapy in relapse of nephrotic syndrome, Outcome 7 Serious adverse events.

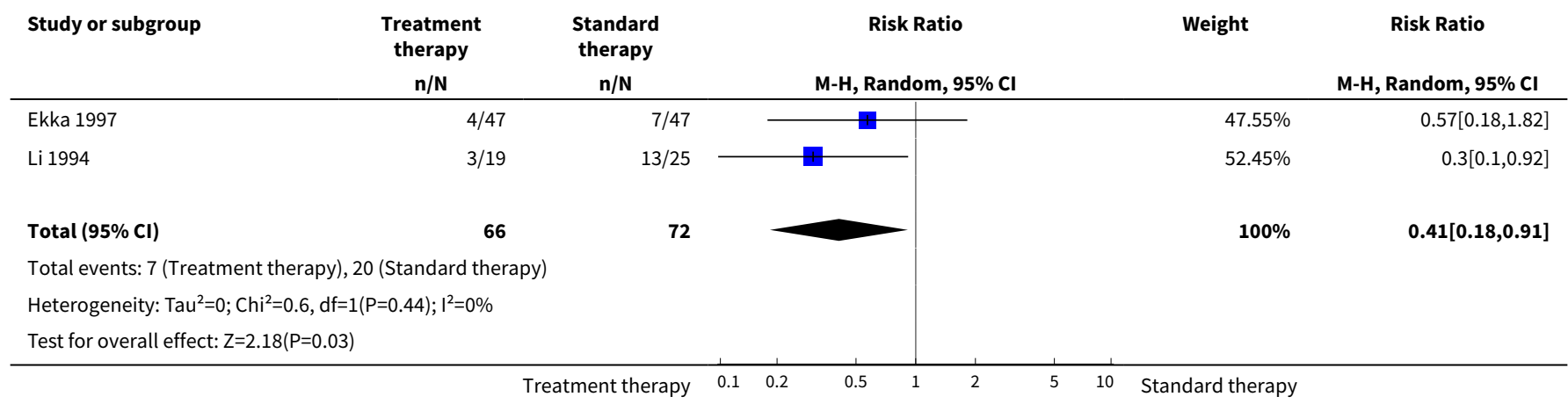

Comparison 12. Prolonged steroid therapy (7 months) for relapsing nephrotic syndrome

\begin{tabular}{lllll}
\hline Outcome or subgroup title & $\begin{array}{l}\text { No. of } \\
\text { studies }\end{array}$ & $\begin{array}{l}\text { No. of } \\
\text { partici- } \\
\text { pants }\end{array}$ & Statistical method & Effect size \\
\hline 1 Number with relapses & 1 & & $\begin{array}{l}\text { Risk Ratio (M-H, Random, 95\% } \\
\text { Cl) }\end{array}$ & Totals not selected \\
\hline 1.1 Relapse by 6 months & 1 & $\begin{array}{l}\text { Risk Ratio (M-H, Random, 95\% } \\
\mathrm{Cl})\end{array}$ & $0.0[0.0,0.0]$ \\
\hline 1.2 Relapse by 12 months & 1 & $\begin{array}{l}\text { Risk Ratio (M-H, Random, 95\% } \\
\mathrm{Cl})\end{array}$ & $0.0[0.0,0.0]$ \\
\hline \hline
\end{tabular}




\begin{tabular}{|c|c|c|c|c|}
\hline Outcome or subgroup title & $\begin{array}{l}\text { No. of } \\
\text { studies }\end{array}$ & $\begin{array}{l}\text { No. of } \\
\text { partici- } \\
\text { pants }\end{array}$ & Statistical method & Effect size \\
\hline 1.3 Relapse by 2 years & 1 & & $\begin{array}{l}\text { Risk Ratio (M-H, Random, 95\% } \\
\mathrm{Cl})\end{array}$ & $0.0[0.0,0.0]$ \\
\hline 1.4 Relapse by 3 years & 1 & & $\begin{array}{l}\text { Risk Ratio (M-H, Random, 95\% } \\
\mathrm{Cl})\end{array}$ & $0.0[0.0,0.0]$ \\
\hline 2 Relapse rate/patient/y & 1 & & $\begin{array}{l}\text { Mean Difference (IV, Random, } \\
95 \% \mathrm{CI})\end{array}$ & Totals not selected \\
\hline 2.1 Relapse rate at 1 year & 1 & & $\begin{array}{l}\text { Mean Difference (IV, Random, } \\
95 \% \mathrm{CI})\end{array}$ & $0.0[0.0,0.0]$ \\
\hline 2.2 Relapse rate at 2 years & 1 & & $\begin{array}{l}\text { Mean Difference (IV, Random, } \\
95 \% \mathrm{CI} \text { ) }\end{array}$ & $0.0[0.0,0.0]$ \\
\hline 2.3 Relapse rate at 3 years & 1 & & $\begin{array}{l}\text { Mean Difference (IV, Random, } \\
95 \% \mathrm{Cl} \text { ) }\end{array}$ & $0.0[0.0,0.0]$ \\
\hline $\begin{array}{l}3 \text { Number with frequently relapsing or } \\
\text { steroid dependent nephrotic syndrome }\end{array}$ & 1 & & $\begin{array}{l}\text { Risk Ratio (M-H, Random, 95\% } \\
\text { Cl) }\end{array}$ & Totals not selected \\
\hline 4 Cumulative steroid dose & 1 & & $\begin{array}{l}\text { Mean Difference (IV, Random, } \\
95 \% \mathrm{CI} \text { ) }\end{array}$ & Totals not selected \\
\hline 4.1 After 1 year & 1 & & $\begin{array}{l}\text { Mean Difference (IV, Random, } \\
95 \% \mathrm{CI} \text { ) }\end{array}$ & $0.0[0.0,0.0]$ \\
\hline 4.2 After 2 years & 1 & & $\begin{array}{l}\text { Mean Difference (IV, Random, } \\
95 \% \mathrm{CI} \text { ) }\end{array}$ & $0.0[0.0,0.0]$ \\
\hline 4.3 After 3 years & 1 & & $\begin{array}{l}\text { Mean Difference (IV, Random, } \\
95 \% \mathrm{CI})\end{array}$ & $0.0[0.0,0.0]$ \\
\hline 5 Adverse effects & 1 & & $\begin{array}{l}\text { Risk Ratio (M-H, Random, 95\% } \\
\text { Cl) }\end{array}$ & Totals not selected \\
\hline 5.1 Number with hypertension & 1 & & $\begin{array}{l}\text { Risk Ratio (M-H, Random, 95\% } \\
\text { Cl) }\end{array}$ & $0.0[0.0,0.0]$ \\
\hline 5.2 Number with growth failure & 1 & & $\begin{array}{l}\text { Risk Ratio (M-H, Random, 95\% } \\
\mathrm{Cl} \text { ) }\end{array}$ & $0.0[0.0,0.0]$ \\
\hline
\end{tabular}

Analysis 12.1. Comparison 12 Prolonged steroid therapy (7 months) for relapsing nephrotic syndrome, Outcome 1 Number with relapses.

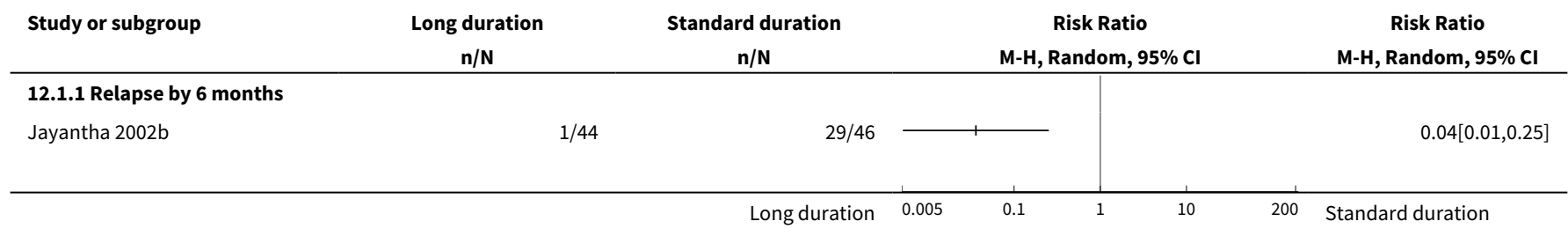




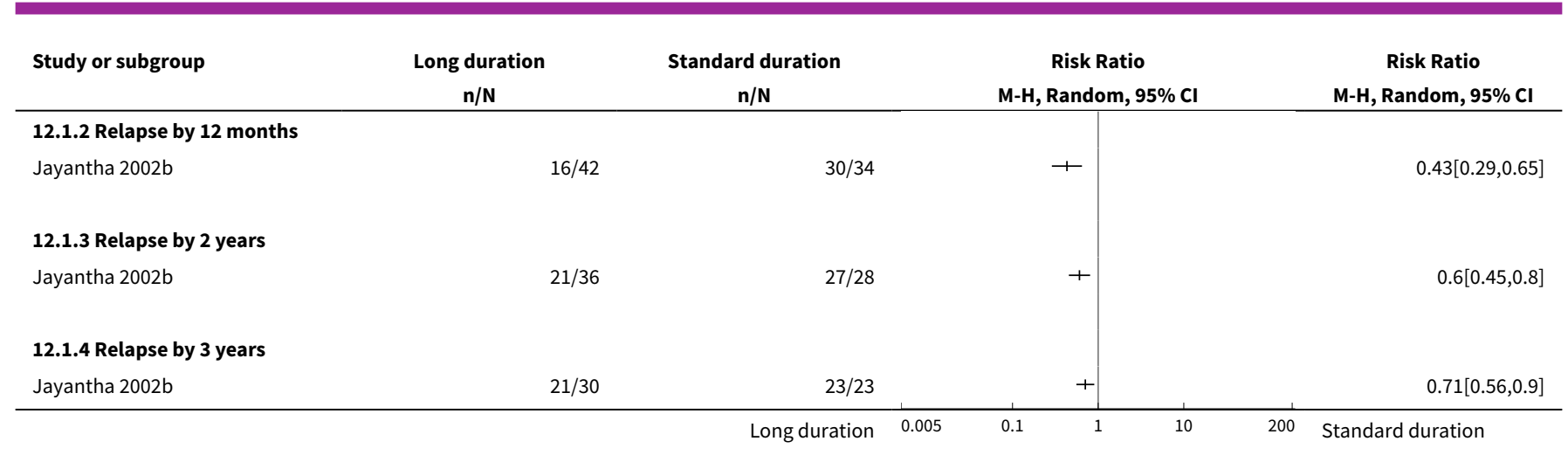

Analysis 12.2. Comparison 12 Prolonged steroid therapy (7 months) for relapsing nephrotic syndrome, Outcome 2 Relapse rate/patient/y.

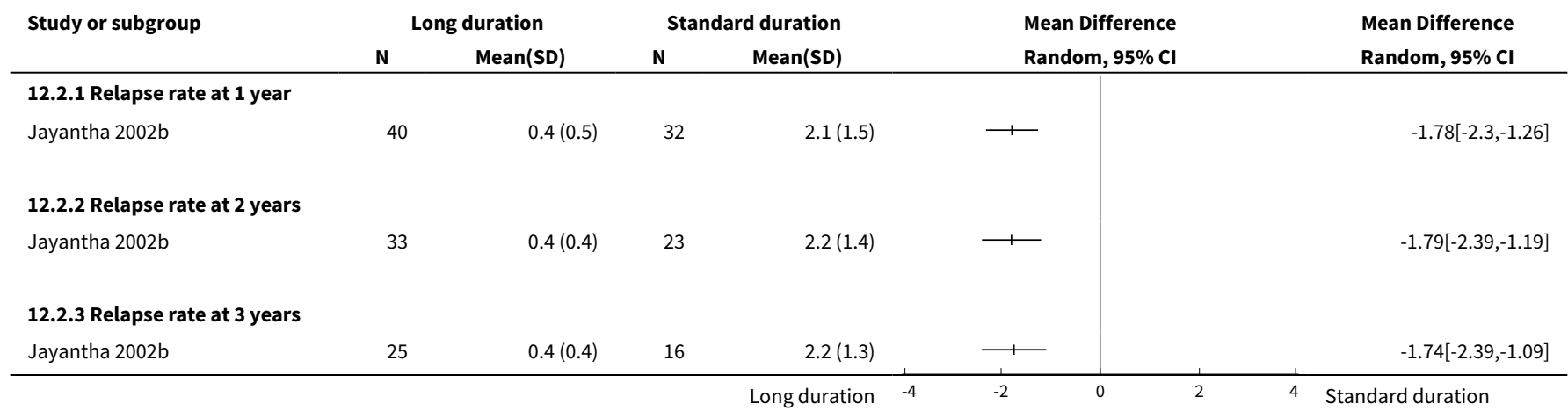

Analysis 12.3. Comparison 12 Prolonged steroid therapy ( 7 months) for relapsing nephrotic syndrome, Outcome 3 Number with frequently relapsing or steroid dependent nephrotic syndrome.

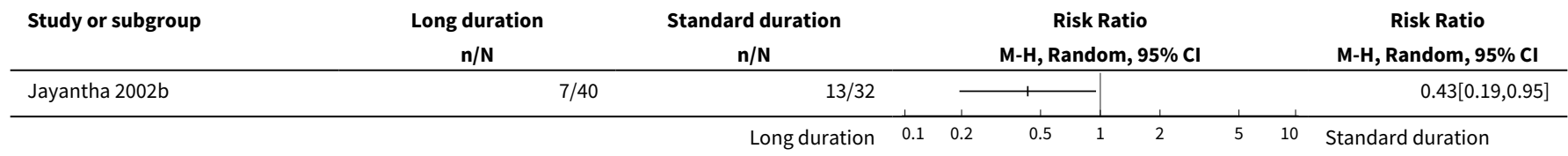

Analysis 12.4. Comparison 12 Prolonged steroid therapy (7 months) for relapsing nephrotic syndrome, Outcome 4 Cumulative steroid dose.

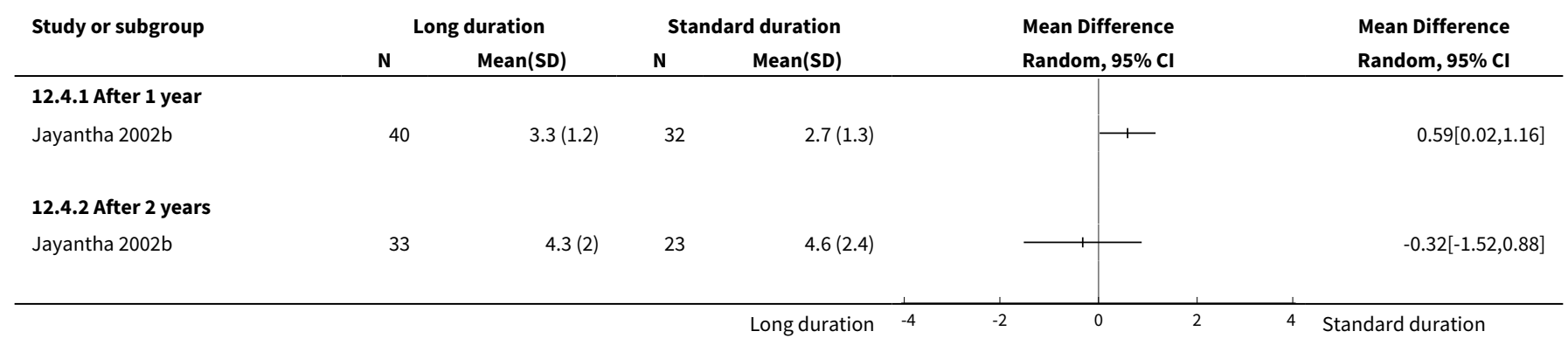




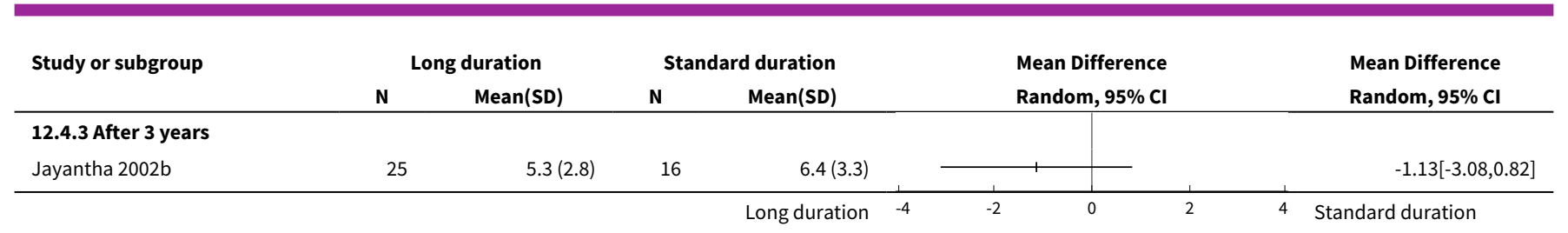

Analysis 12.5. Comparison 12 Prolonged steroid therapy (7 months) for relapsing nephrotic syndrome, Outcome 5 Adverse effects.

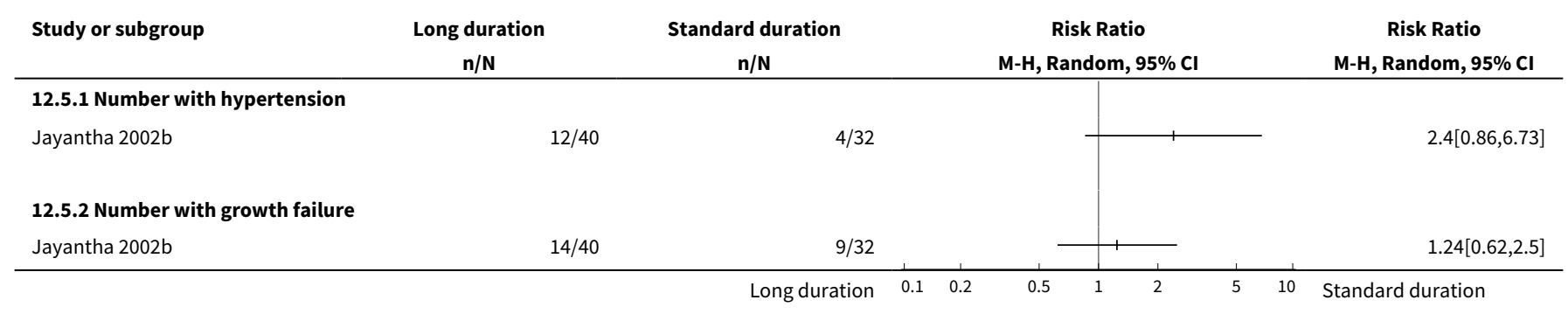

\section{ADDITIONAL TABLES}

Table 1. Outcomes of studies in children with relapsing nephrotic syndrome

\begin{tabular}{|c|c|c|c|c|c|c|}
\hline Study ID & $\begin{array}{l}\text { Relapse } \\
\text { on ther- } \\
\text { apy }(\mathrm{RR} \\
(95 \% \mathrm{CI}))\end{array}$ & $\begin{array}{l}\text { Relapse } \\
\text { by } 9 \\
\text { months } \\
\text { (RR (95\% } \\
\text { CI)) }\end{array}$ & $\begin{array}{l}\text { Relapse by } \\
12 \text { months } \\
\text { (RR ( } 95 \% \\
\text { CI)) }\end{array}$ & $\begin{array}{l}\text { Mean re- } \\
\text { lapse rate } \\
\text { MD }(95 \% \\
\mathrm{CI}))\end{array}$ & $\begin{array}{l}\text { Mean } \\
\text { time to } \\
\text { remission } \\
\text { (MD (95\% } \\
\mathrm{CI})\end{array}$ & Steroid therapy \\
\hline APN 1981 & $\begin{array}{l}0.60(0.36 \\
\text { to } 1.02)\end{array}$ & & $\begin{array}{l}1.20(0.93 \\
\text { to } 1.55)\end{array}$ & $\begin{array}{l}-0.20(-0.65 \\
\text { to } 0.25)\end{array}$ & & Alternate-day versus intermittent \\
\hline $\begin{array}{l}\text { Broyer } \\
1997\end{array}$ & & & $\begin{array}{l}0.44(0.25 \\
\text { to } 0.78)\end{array}$ & $\begin{array}{l}-1.90(-2.77 \\
\text { to }-1.03)\end{array}$ & & Deflazacort versus prednisone \\
\hline Ekka 1997 & & $\begin{array}{l}1.07(0.77 \\
\text { to } 1.50)\end{array}$ & & & & Daily versus divided dose prednisone \\
\hline $\begin{array}{l}\text { Imbasciati } \\
1985\end{array}$ & & & $\begin{array}{l}1.06(0.75 \\
\text { to } 1.52)\end{array}$ & & & IV and oral versus oral prednisone \\
\hline $\begin{array}{l}\text { ISKDC } \\
1979\end{array}$ & $\begin{array}{l}0.20(0.05 \\
\text { to } 0.82)\end{array}$ & $\begin{array}{l}1.00(0.89 \\
\text { to } 1.12)\end{array}$ & & $\begin{array}{l}0.54(-0.50 \\
\text { to } 1.58)\end{array}$ & & Daily versus intermittent prednisone \\
\hline $\begin{array}{l}\text { Jayantha } \\
2002 b\end{array}$ & & & $\begin{array}{l}0.43(0.29 \\
\text { to } 0.65)\end{array}$ & $\begin{array}{l}-1.78(-2.30 \\
\text { to }-1.26)\end{array}$ & & $\begin{array}{l}7 \text { months prednisone versus standard ISKDC } \\
\text { regimen for relapse }\end{array}$ \\
\hline Leisti 1978 & & & & & & $\begin{array}{l}\text { Cortisol versus placebo in FRNS (cross-over): } \\
5 / 13(38 \%) \text { on cortisol relapsed versus } 12 / 13 \\
(92 \%) \text { on placebo }\end{array}$ \\
\hline
\end{tabular}


Table 1. Outcomes of studies in children with relapsing nephrotic syndrome (Continued)
Li 1994
0.04 days
Daily versus divided dose prednisone
$(-0.98$ to
1.06)

Liern 2008

Time to relapse (cross-over): deflazacort $105 \pm$

4.19 days versus methylprednisolone $85 \pm 3.8$

days

FRNS - frequently relapsing nephrotic syndrome; ISKDC - International Study of Kidney Disease in Children

\section{APPENDICES}

\section{Appendix 1. Electronic search strategies}

\begin{tabular}{ll}
\hline Database & Search terms \\
\hline CENTRAL & 1. MeSH descriptor: [Nephrotic Syndrome] this term only \\
2. MeSH descriptor: [Nephrosis, Lipoid] this term only \\
3. "nephrotic syndrome" \\
4. "lipoid nephrosis" \\
5. \#1 or \#2 or \#3 or \#4 \\
6. child* or infant* \\
7. boy* or girl* \\
8. pediatric ${ }^{\star}$ or paediatric* \\
9. \#6 or \#7 or \#8 \\
10.\#5 and \#9
\end{tabular}

\begin{tabular}{ll}
\hline MEDLINE & 1. nephrotic syndrome/ \\
2. nephrosis, lipoid/ \\
3. nephrotic syndrome.tw. \\
4. lipoid nephrosis.tw. \\
5. or/1-4 \\
6. exp child/ \\
7. exp Infant/ \\
8. child\$.tw. \\
9. infant\$.tw. \\
10.(boy $\$$ or girl\$).tw. \\
11.(pediatric or paediatric).tw. \\
12.or/7-12 \\
13.and/5,12
\end{tabular}

EMBASE

1. nephrotic syndrome/

2. lipoid nephrosis/

3. nephrotic syndrome.tw.

4. lipoid nephrosis.tw.

5. or/1-4

6. $\exp$ Child/

7. child\$.tw.

8. infant\$.tw. 


\author{
9. (boy $\$$ or girl\$).tw. \\ 10. (pediatric or paediatric).tw \\ 11.or/6-10 \\ 12.and $/ 5,11$
}

Appendix 2. Risk of bias assessment tool

\begin{tabular}{|c|c|}
\hline Potential source of bias & Assessment criteria \\
\hline \multirow{3}{*}{$\begin{array}{l}\text { Random sequence genera- } \\
\text { tion } \\
\text { Selection bias (biased alloca- } \\
\text { tion to interventions) due to } \\
\text { inadequate generation of a } \\
\text { randomised sequence }\end{array}$} & $\begin{array}{l}\text { Low risk of bias: Random number table; computer random number generator; coin tossing; shuf- } \\
\text { fling cards or envelopes; throwing dice; drawing of lots; minimisation (minimisation may be imple- } \\
\text { mented without a random element, and this is considered to be equivalent to being random). }\end{array}$ \\
\hline & $\begin{array}{l}\text { High risk of bias: Sequence generated by odd or even date of birth; date (or day) of admission; se- } \\
\text { quence generated by hospital or clinic record number; allocation by judgement of the clinician; by } \\
\text { preference of the participant; based on the results of a laboratory test or a series of tests; by avail- } \\
\text { ability of the intervention. }\end{array}$ \\
\hline & Unclear: Insufficient information about the sequence generation process to permit judgement. \\
\hline $\begin{array}{l}\text { Allocation concealment } \\
\text { Selection bias (biased alloca- } \\
\text { tion to interventions) due to } \\
\text { inadequate concealment of al- }\end{array}$ & $\begin{array}{l}\text { Low risk of bias: Randomisation method described that would not allow investigator/participant to } \\
\text { know or influence intervention group before eligible participant entered in the study (e.g. central } \\
\text { allocation, including telephone, web-based, and pharmacy-controlled, randomisation; sequential- } \\
\text { ly numbered drug containers of identical appearance; sequentially numbered, opaque, sealed en- } \\
\text { velopes). }\end{array}$ \\
\hline
\end{tabular}

High risk of bias: Using an open random allocation schedule (e.g. a list of random numbers); assignment envelopes were used without appropriate safeguards (e.g. if envelopes were unsealed or non-opaque or not sequentially numbered); alternation or rotation; date of birth; case record number; any other explicitly unconcealed procedure.

Unclear: Randomisation stated but no information on method used is available.

\section{Blinding of participants and personnel}

Performance bias due to knowledge of the allocated interventions by participants and personnel during the study
Low risk of bias: No blinding or incomplete blinding, but the review authors judge that the outcome is not likely to be influenced by lack of blinding; blinding of participants and key study personnel ensured, and unlikely that the blinding could have been broken.

High risk of bias: No blinding or incomplete blinding, and the outcome is likely to be influenced by lack of blinding; blinding of key study participants and personnel attempted, but likely that the blinding could have been broken, and the outcome is likely to be influenced by lack of blinding.

Unclear: Insufficient information to permit judgement

\section{Blinding of outcome assess- ment}

Detection bias due to knowledge of the allocated interventions by outcome assessors.
Low risk of bias: No blinding of outcome assessment, but the review authors judge that the outcome measurement is not likely to be influenced by lack of blinding; blinding of outcome assessment ensured, and unlikely that the blinding could have been broken.

High risk of bias: No blinding of outcome assessment, and the outcome measurement is likely to be influenced by lack of blinding; blinding of outcome assessment, but likely that the blinding could have been broken, and the outcome measurement is likely to be influenced by lack of blinding.

Unclear: Insufficient information to permit judgement 
(Continued)

\section{Incomplete outcome data}

Attrition bias due to amount, nature or handling of incomplete outcome data.
Low risk of bias: No missing outcome data; reasons for missing outcome data unlikely to be related to true outcome (for survival data, censoring unlikely to be introducing bias); missing outcome data balanced in numbers across intervention groups, with similar reasons for missing data across groups; for dichotomous outcome data, the proportion of missing outcomes compared with observed event risk not enough to have a clinically relevant impact on the intervention effect estimate; for continuous outcome data, plausible effect size (difference in means or standardised difference in means) among missing outcomes not enough to have a clinically relevant impact on observed effect size; missing data have been imputed using appropriate methods.

High risk of bias: Reason for missing outcome data likely to be related to true outcome, with either imbalance in numbers or reasons for missing data across intervention groups; for dichotomous outcome data, the proportion of missing outcomes compared with observed event risk enough to induce clinically relevant bias in intervention effect estimate; for continuous outcome data, plausible effect size (difference in means or standardized difference in means) among missing outcomes enough to induce clinically relevant bias in observed effect size; 'as-treated' analysis done with substantial departure of the intervention received from that assigned at randomisation; potentially inappropriate application of simple imputation.

Unclear: Insufficient information to permit judgement

\section{Selective reporting}

Reporting bias due to selective outcome reporting
Low risk of bias: The study protocol is available and all of the study's pre-specified (primary and secondary) outcomes that are of interest in the review have been reported in the pre-specified way; the study protocol is not available but it is clear that the published reports include all expected outcomes, including those that were pre-specified (convincing text of this nature may be uncommon).

High risk of bias: Not all of the study's pre-specified primary outcomes have been reported; one or more primary outcomes is reported using measurements, analysis methods or subsets of the data (e.g. sub-scales) that were not pre-specified; one or more reported primary outcomes were not prespecified (unless clear justification for their reporting is provided, such as an unexpected adverse effect); one or more outcomes of interest in the review are reported incompletely so that they cannot be entered in a meta-analysis; the study report fails to include results for a key outcome that would be expected to have been reported for such a study.

Unclear: Insufficient information to permit judgement

\section{Other bias}

Bias due to problems not covered elsewhere in the table
Low risk of bias: The study appears to be free of other sources of bias.

High risk of bias: Had a potential source of bias related to the specific study design used; stopped early due to some data-dependent process (including a formal-stopping rule); had extreme baseline imbalance; has been claimed to have been fraudulent; had some other problem.

Unclear: Insufficient information to assess whether an important risk of bias exists; insufficient rationale or evidence that an identified problem will introduce bias.

WHAT'S NEW

\begin{tabular}{lll}
\hline Date & Event & Description \\
\hline 16 September 2015 & Amended & $\begin{array}{l}\text { Minor amendment to forest plot description 2.8.2 - changed from } \\
\text { 'Low risk...' to "High risk..." }\end{array}$ \\
\hline
\end{tabular}

\section{H IST ORY}

Protocol first published: Issue 2, 1999 
Review first published: Issue 4, 2000

\begin{tabular}{lll}
\hline Date & Event & Description \\
\hline 11 March 2015 & $\begin{array}{l}\text { New citation required and conclusions } \\
\text { have changed }\end{array}$ & 10 new studies included \\
\hline 11 March 2015 & New search has been performed & New studies identified \\
\hline 13 May 2009 & Amended & Contact details updated. \\
\hline 23 September 2008 & Amended & Converted to new review format. \\
\hline 21 August 2007 & $\begin{array}{l}\text { New citation required and conclusions } \\
\text { have changed }\end{array}$ & Substantive amendment \\
\hline
\end{tabular}

\section{CONTRIBUTIONS OFAUTHORS}

- Deidre Hahn: Study selection, quality appraisal, data extraction, data analysis, writing review, updating review.

- Elisabeth Hodson: Study selection, quality appraisal, data extraction, data analysis, writing review, updating review.

- Narelle Willis: Literature search, obtaining articles, organising translation, data extraction, data analysis, data display, updating review.

- Jonathan Craig: Data analysis, writing review, updating review.

\section{DECLARATIONS OF INTEREST}

- Deirdre Hahn: none known

- Elisabeth Hodson: none known

- Narelle Willis: none known

- Jonathan Craig: none known

\section{SOURCES OF SUPPORT}

\section{Internal sources}

- No sources of support supplied

\section{External sources}

- Australian Kidney Foundation, Australia.

- National Health and Medical Research Council, Australia.

- Commonwealth Department of Health and Aging, Australia.

\section{DIFFERENCES BETWEEN PROTOCOLANDREVIEW}

Risk of bias assessment tool has replaced the Quality assessment checklist list used in the previous versions of this review.

\section{N DEX TERMS}

\section{Medical Subject Headings (MeSH)}

Anti-Inflammatory Agents [ ${ }^{\star}$ therapeutic use]; Drug Administration Schedule; Glucocorticoids [adverse effects] [therapeutic use]; Nephrotic Syndrome [ ${ }^{\star} \mathrm{drug}$ therapy]; Prednisone [therapeutic use]; Pregnenediones [therapeutic use]; Randomized Controlled Trials as Topic; Recurrence; Respiratory Tract Infections [drug therapy] [virology]; Secondary Prevention; Virus Diseases [drug therapy]

\section{MeSH check words}

Adolescent; Child; Child, Preschool; Humans; Infant 